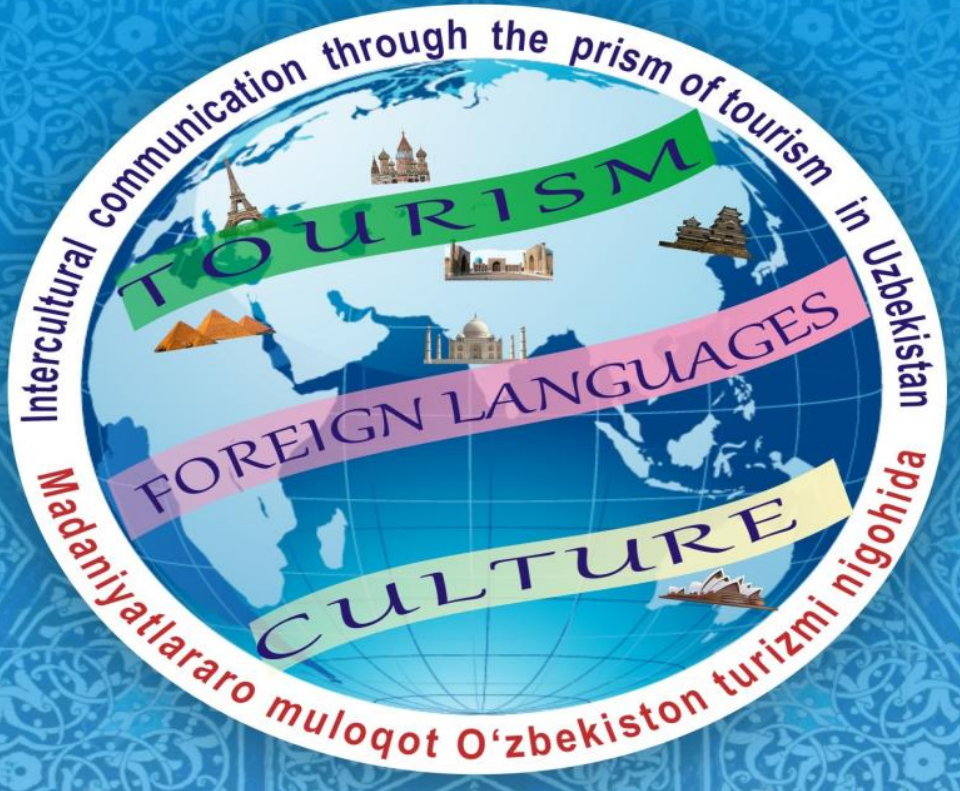

INTERCULTURAL COMMUNICATION THROUGH THE PRISM OF TOURISM IN UZBEKISTAN: EXPERIENCE, CURRENT ISSUES AND PERSPECTIVES MADANIYATLARARO MULOQOT O'ZBEKISTON TURIZMI NIGOHIDA: TAJRIBA, DOLZARB MUAMMOLAR VA ISTIQBOLLAR

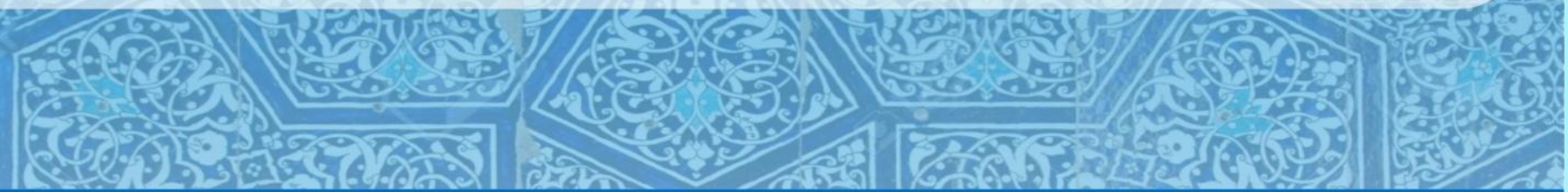

XALQARO ILIMIY-AIVIALIY ANJUIMIAN

MATERIALLARI
PROCEEDINGS

OF INTERNATIONAL SCIENTIFIC-PRACTICAL CONFERENCE

\title{
2- ҚИСМ
}
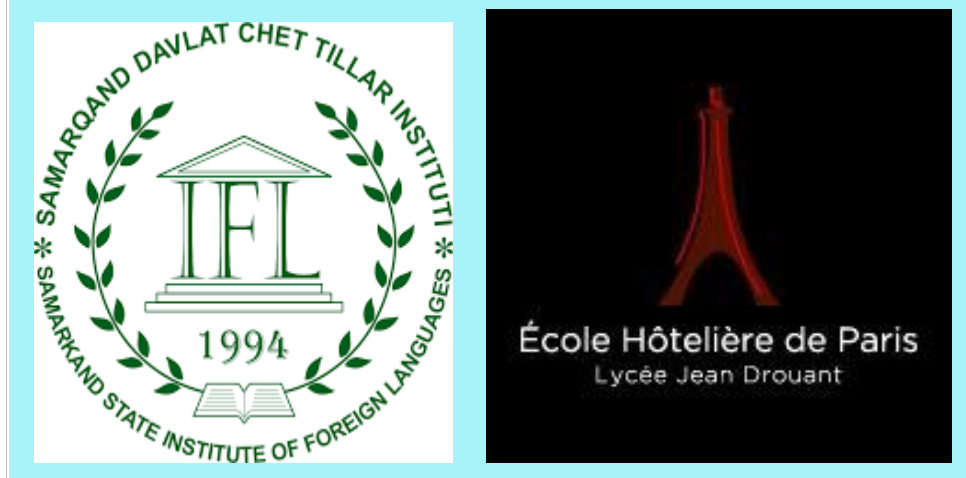

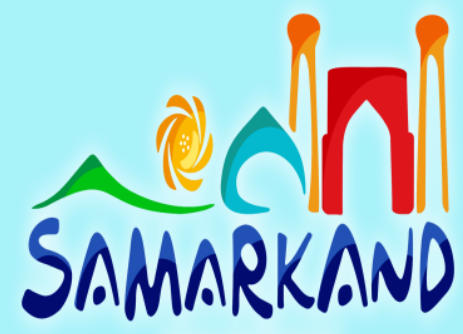

ENJOY HOSPITALITY 



\author{
ЎЗБЕКИСТОН РЕСПУБЛИКАСИ \\ ОЛИЙ ВА ЎРТА МАХСУС ТАЪЛИМ ВАЗИРЛИГИ
}

САМАРҚАНД ДАВЛАТ ЧЕТ ТИЛЛАР ИНСТИТУТИ

МАДАНИЯТЛАРАРО МУЛОҚОТ ЎЗБЕКИСТОН

ТУРИЗМИ НИГОХИДА: ТАЖРИБА, ДОЛЗАРБ

МУАММОЛАР ВА ИСТИҚБОЛЛАР

\title{
INTERCULTURAL COMMUNICATION THROUGH THE PRISM OF TOURISM IN UZBEKISTAN: EXPERIENCE, CURRENT ISSUES AND PERSPECTIVES
}

Халқаро илмий-амалий анжумани

МАТЕРИАЛЛАРИ

PROCEEDINGS

of international scientific-practical conference

$$
\text { 2- ҚИСМ 2-PART }
$$

Самарқанд шахри, 2020 йил, 29-30 июнь

Samarkand city, June 29-30, 2020

Самарқанд - 2020

Samarkand - 2020 


\section{УўК 4}

\section{ББК 81.2-5}

M 13

Маданиятлараро мулоқот Ўзбекистон туризми нигохида: тажриба, долзарб муаммолар ва истиқболлар. Халқаро илмий-амалий анжуман материаллари. Самарқанд: СамдЧТИ, 2019. - 366 бет.

Мазкур халқаро илмий-амалий конференция материалларидан иборат тўпламга хорижий тиллар - маданий меросни талқин қилиш асоси сифатида, мулоқот жараёнида лингвомаданий хусусиятларнинг воқеланиши, туризм сохаси вакилларининг лингвистик ва ижтимоий-маданий салохиятини ривожлантириш асослари, Ўзбекистонда туризмни ривожлантиришнинг истиқболлари, маданиятлараро мулоқот хорижий тил таълимининг етакчи омили сифатида каби масалаларга оид мақолалар киритилган. Конференция туризм, хорижий тил ва маданият сингари уч хил бошқабошқа сохаларнинг ижтимоий-иқтисодий, маданий ва таълим каби долзарб йўналишларда бир-бири билан ўзаро уйғунлашган холда акс этишини ўз ичига олади. Ушбу сохалар бўйича анча тажрибага эга хамда илмий нашрлари билан илм ахли назарига тушган устоз-олимлар: филологлар, тарихчилар, маданиятшунослар, педагоглар ва гид-таржимонлар билан бир қаторда, шу жабхаларда илмий кузатишларини эндигина бошлаган тадқиқотчилар, магистрантларнинг хам изланиш натижалари мазкур тўпламдан ўрин олди. Тўплам маданиятлараро мулоқот, туризм, тарих, маданият, хорижий тиллар каби масалалар билан қизиқувчи кенг китобхонлар оммасига мўлжалланган.

The conference is scheduled for the plenary session and the following sections: foreign languages as a basis for the interpretation of cultural heritage, focus on linguo-cultural features in the process of communication, development of linguistic and socio-cultural skills of tourism professionals, prospects for the development of tourism in Uzbekistan, intercultural communication as one of the main directions in the study of a foreign language. The collection includes scientists' articles who has a great amount of experience in the field of linguistics, history, culture, pedagogy and guide translator, besides that the collection includes young researchers' and master students' articles. The collection is designed for the researchers who are interested in the issue of intercultural communication, tourism, history, culture and foreign languages.

\section{Тахрир хайъати / Editorial board}

п.ф.д. И.М.Тухтасинов (раис) Tukhtasinov I.M. (chairman)

доч. Ш.С. Ашуров (раис ўринбосари) Ashurov Sh.S (vice-chairman)

проф. Ш.C. Сафаров Safarov Sh.S.

доц. С.И. Исмоилов Ismoilov S.I.

ф.ф.н. Д.А. Киселев Kiselyov D.A.

ф.ф.н. Н.Н. Сувонова (масъул мухаррир) Suvonova N.N. (chief editor)

к.ўқ. Р.А. Шукурова (масъул котиб) Shukurova R.A. (executive secretary)

\section{Тўпламдан ўрин олган мақолаларнинг савияси, сифати ва илмий далилларнинг хаққонийлиги хамда мазмуни учун муаллифлар масъулдирлар.}




\section{К ВОПРОСУ О ЗНАЧЕНИИ ЛИНГВОФИЛОСОФСКОГО НАСЛЕДИЯ АЛИШЕРА НАВОИ}

\section{Меликова Мартаба Нумоновна PhD, доцент, Самаркандский государственный институт иностранных языков E-mail: melikova@samdchti.uz}

Annotation: This article highlights the significance of the linguophilosophical heritage of the great poet and thinker Alisher Navoi, whose writings reflect the issues of linguistics, philosophy, politics, social justice and spiritual development of the individual. The huge role of the ethical and spiritual heritage of Alisher Navoi for the revival of the spirituality of the Uzbek people is shown.
Key words: linguophilosophy, heritage, spirituality, social justice, greatness of the Uzbek language.

Историческое значение творчества Алишера Навои помимо его вклада в области литературной, государственной и благотворительной деятельности (на его средства построено много общественных зданий, им оказана большая материальная и моральная поддержка многим деятелям культуры, студентам и преподавателям медресе), заключается в утверждении им статуса литературы на турки наравне с литературой на фарси и арабском языках. Для этой цели им была написана специальная книга «Мухакамат ул лугатайн» (Спор двух Языков). В ней Навои, раскрывая все богатство языка турки, обосновал самостоятельность существования туркоязычной литературы. Поэт пишет, что арабский язык является избранным и исключительным благодаря своей образности и изяществу, а также благодаря тому, что на этом языке ниспосланы божественное откровение и сунна (хадисы) пророка. Кроме арабского он выделяет три близких языка - хинди, фарси (сартский язык) и турки. На этих языках говорили и общались на исторически общей территории три народа, у которых много общего в культуре и обычаях. Но особенно близкими Навои считает турков и сартов, которые во всех своих поколениях сильно перемешаны друг с другом. Характеризуя их, он отмечает, что турки более сообразительны и чрезвычайно понятливы, натура их более благородна, а сарты - более внимательны к умственному развитию и знаниям, основательнее проявляют себя в ученых размышлениях. Вместе с тем отмечается, что турки превосходят сартов в усвоении их языка и культурных ценностей: все турки понимают сартский язык, а их поэты на языке фарси пишут красочные стихи и произносят замечательные речи. Но среди сартов не все могут говорить на турки, а если кто и говорит, то легко понять, что тот - сарт[5].

Рассуждая таким образом, Навои приводит свои аргументы в пользу утверждения литературы на турки и самостоятельности этого языка наравне с другими. Эта мысль нередко прослеживается и в поэмах «Хамсы». В поэме «Смятение праведных» Навои, высоко оценивая «Пятерицы» своих персоязычных предшественников Низами Гянджави (XIII в.), Хусрава Дехлеви (XIV в.) и Абдурахмана Джами, отмечает, что в их поэмах «слово жаром Истины горит, превращая камень в воду». Потрясенный их творениями, он решил создать собственную «Пятерицу»на турки: Желая вслед великим трем идти -

Хоть шага три пройти по их пути,

Решил: писали на фарси они,

А ты на тюркском языке начни!

Хоть на фарси их подвиг был велик

Но пусть и тюркский славится язык

(Перевод В. Державина)[5]. 
Навои оставил богатое духовное творческое наследие, насчитывающее 29 произведений. Его перу принадлежат поэтические произведения «Хамса»,включающие в себя пять поэм: «Смятение праведных», «Лайли и Маджнун», «Фархад и Ширин», «Семь планет», «Стена Александра», "Сокровищница мысли", собрание лирических стихов поэта, написанных в разные годы его жизни. Оно имеет оригинальное построение - в последовательности, характерной для времен года, поэт разделил его на четыре части: «Гаройиб ас сигар» - «Диковины детства», «Наводир аш шабоб» «Редкости молодости», «Бадаил ал васат»- «Чудеса среднего возраста», «Фаваид ал кибар» - «Полезные наставления старости».

Основной лейтмотив творчества Навои - глубокие раздумья о человеке и его духовном мире, размышления о мироздании и смысле жизни - рассматривается сквозь призму понятий «любовь» и «красота». Красота в своей чувственновоспринимаемой форме, в отличие от абсолютной красоты, олицетворяющей собой божественное начало в мире, ассоциируется с видимым миром, а любовь выступает как движущая сила и средство постижения красоты. Поэтому красота доступна только тем, кто смотрит на мир чистым взором и имеет чистое сердце. Этой идеей проникнута вся лирика поэта. В ней эти два начала - любовь и красота - органически сливаются. В трактовке поэта-мыслителя любовь - это одухотворенная моральная сила, очищающая человека от накипи страстей и пороков, воспитывающая его в духе высоких моральных принципов, наставляющая на путь благородства, мужества духа и испытаний в верности, требующая активного проявления человеком своих способностей и духовных сил [3]. Такая любовь требует от человека самосовершенствования и самопознания, обрекает его на множество мук и страданий. Именно такой любовью окрылены герои Навои Фархад, Маджнун, Лайли, Ширин.

Внутренний, скрытый смысл поэм - изображение идеального мира, мира справедливости и взаимопонимания, мира согласия и гармонии, мира любви и добродетели, в котором добро всегда одерживает победу над злом. В понятиях любовьи красота отражаются все сложные человеческие отношения, духовный мир человека, его внутренние переживания[4].

Внешний сюжет поэм - история трагической любви, бытующей в преданиях народов Востока. В описании любви Навои передает тончайшие эмоционально-психологические переживания героев, их внутренний мир, показывает характерные картинки жизни современного ему феодального общества: бесправное положение женщины, родоплеменные распри и предрассудки, произвол и деспотизм правителей.

Произведения Алишера Навои проникнуты любовью к людям, которых он призывает к добрым делам, к сотрудничеству и взаимопониманию, наставляет правителей и их сановников на путь добра и справедливости. В них полно и убедительно выступает лирический герой Навои - поэт-философ, поэт-мыслитель, поэт-гуманист, мечтавший о царстве просвещения и нравственных добродетелей, о наступлении эры справедливости и всеобщего благоденствия. Он был искренен в своих устремлениях и был убежден в том, что просвещение людей, воспитание их в духе высоких нравственных начал устранит порожденные невежеством и грубостью нравов жестокость, алчность, несправедливость и предательство, будет способствовать установлению доверия и уважения между людьми. Эта любовь к человеку, желание улучшить его жизнь нашли свое выражение не только в творчестве, но и в огромной материальной помощи, которую поэт щедро и великодушно оказывал нуждающимся [1-5].

Живучесть и жизнеутверждающая сила поэтического творчества Навои заключается в том, что каждое новое поколение воспринимает художественное видение великого поэта в соответствии с собственным мироощущением, 
художественно-эстетическим вкусом, открывая для себя все новые и новые грани его творчества.

\section{Литературы:}

1. Алишер Навои. Собрание сочинений в 10 томах. Смятение праведных.Том III.T.1968.271 с.

2. Алишер Навои. Собрание сочинений в 10 томах. Язык птиц. T VIII. T. 1968. 344 с.

3. Алишер Навои. Собрание сочинений в 10 томах. Стена Искандара. T VII. T. 1968. 414 с.

4. Алишер Навои. Собрание сочинений в 10 томах. Фархад и Ширин. T IV. T. 1968. 408 с.

5. Алишер Навои. Поэмы. М. Художественная литература. 1972. 829 с.

\section{КОРЕЙС ВА ЎЗБЕК ОИЛАСИДА \\ ЭРКАКЛАРГА НИСБАТАН ҚЎЛЛАНАДИГАН МУРОЖААТЛАР}

\section{Аширбаева Дилором Равшановна \\ Тошкент давлат шарқшунослик университети, мустақил тадқиқотчи E-mail : hangook2019@gmail.com}

Annotation : This article is devoted to speech appealing units in the Korean and Uzbek family discourse. It displays the area of use, similar and distinctive aspects of translating in two languages. In Korean, there are special speech units that are used separately for boys and girls to indicate to brother and sister, or special speech units when referring to grandparents. On the one hand, these special speech units, may seem simple, but in other they can lead to some translation difficulties. Also, in this article are considered such appealing forms which are used in the designation of biological parents and their gentle equivalents, the parents of a friend and wife. In addition, comparative analyzes of such speech units that are used in family relationships are given.

Key words : Terms of appealing, discourse,

family, parents, brothers, , grandparents, husband, boy.

Корейс оиласидаги муносабатлар ғоятда мураккаб бўлиб, “мендан катта //кичик” шартига қатъиян амал қилинади. Катталарга хар доим “сизлаб” гапирилади. Отага абожи, онага омони деб мурожаат қилинади. 아버지 ва 어머니 мурожаати хурматнинг “юқори” даражаси хисобланади. Яқин ўртоқнинг ота-онасига хам 아버지,어머니 деб хитоб қилиш мумкин:

아버지, 저철수의친구연후입니다. [2,75]

“Ота, мен Чолсунинг ўртоғи Ёнхуман

Корейс тилида отага нисбатан қўлланиладиган мурожаат сўзларини уч гурухга

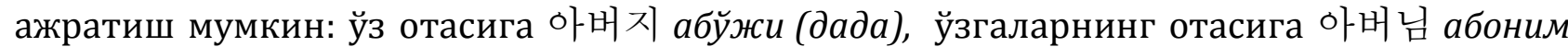
(дада, амаки) ва мархум ота 선친 сончин хақидаги мурожаат бирликлари. [1]. Ўзбек мулоқот маданиятида мархумларга нисбатан махсус мурожаат шакллари мавжуд эмас. Бироқ мархумлар ёдга олинганда, уларнинг исмлари олдидан "рахматлик" сўзи ишлатилади.

Отаси туғишган эканлигини билдириш мақсадида 친 чин “яқин/қондош" сўзи қўшилиб айтилади. 친아빠 чин апnа қондош отам. Мазкур мурожаатларнинг хитой тилидан ўзлашган хурмат шакли 부친 пучин дир.

Эр-хотин муносабатларида хитоб сўзларининг хилма-хиллиги жихатидан корейс тили дунёда энг бой тил хисобланади. Эр-хотинлар (40\%) кўпинча бир-бирига 여보 ёбо (азизим) ёки 자기 чаги деб мурожаат қилишади:

여보, 내말잠들어봐요. [3]

"Азизим, гапимга кулоқ солинг" 
Аёл ўз эрига нисбатан мурожаати ёшини хисобга олиб турлича бўлиши мумкин. Янги турмуш қурилган вақтда 여보 йобў деб мурожаат қилиш мумкин. Аммо, ёши улуғлашгани сари 여보 йобў нинг ўрнига 영감 йонгам дея мурожаат қилиш мақсадга мувофиқ хисобланади.

Оилада фарзанд туғилгач эр-хотин муносабатлари ўзгача тус олади. Жумладан, корейс тилида аёли эрига (фарзанднинг исми+아빠) 수미의아빠 Сумие anna "Сумининг отаси”, ёки 애기아빠 эги апnа “боламнинг отаси” деб мурожаат қилади. [4, 170]. Баъзи ўзбек оилаларида аёл эрига катта ўғлининг исми билан мурожаат қилади. Эрига отаси, дадаси, адаси каби ундалмалар воситасида мурожаат қиладиган кишилар хам бор: Тўғри, дадаси, мен айтаман.

Келинлар қаёнотаси хақида ота уйидагиларига ёки бошқа кишиларга сўзлаётганида 시아버지 щиабожи деб гапиради.

Корейс оиласида ака ва опаларни исми билан чақириш қатъиян ман қилинган. Кези келганда, корейс дискурсининг ўзига хос гендер тафовутларини таъкидлаб ўтиш мақсадга мувофиқ бўлади. Корейс аёлларининг нутқида “ака"오빠 ўnna, эркакларининг нутқида эса "ака" 형 хзёнг кўринишида намоён бўлади.

Қизларнинг нутқида ўта фаол бўлган қариндошлик оти бўлмиш 오빠 ўnna "ака" турли холатларда мурожаат вазифасини ўтайди. Жумладан, улар ўзидан катта йигитларни, унаштирилган йигитларини, хамда ўзидан юқори синфда ёки курсда ўқийдиган болаларни 오빠 ўnna деб чақиришади. Эркакларининг нутқида 형 хёнг "ака" мурожаатини жиноий гурух етакчисига нисбатан хам қўлланилади. Таржима жараёнида бундай холатлар бир оз мураккабликларни келтириб чиқаради.

Поғонали муносабатларда самимиятни ифодалайдиган ва “ака" маъносини берадиган мурожаат бирликларидан яна бири эркакларнинг нутқига хос бўлган 형 дир. 형 ундалмаси акага, қайноғага, ўзидан катталарга, юқори синфда ёки курсда ўқийдиганларга нисбатан ишлатилади. [2, 163]

형, 한까지부탁이있는데들어겠어?

“Ака, бир илтимосим бор эди, атаверайми?"

Оилада буваларнинг хам номланиши бўлиб, уларнинг ота томондан ва она томондан эканлигига қараб турлича номланади. Ота томондан бува 할아버지 харабожи деб мурожаат қилинса, она томондан эса 외할아버지 вихарабожидеб мурожаат қилинади. Ўзбек тилида эса буваларни бобо, бува, катта дада, опоқ дода дея мурожаат этилади. Корейс нутқида ота ёки она томондан боболарга мурожаат қилинувчи бирликлари мавжуд бўлгани учун нутқ жараёнида бобо тингловчига тушунарли бўлиши учун ким томондан эканлигига алохида урғу бериб айтилади.

Хулоса қилиб шуни айтишимиз мумкинки, қариндошлик терминлари мурожаат бирлиги бўлиб келадиган энг фаол сўзлардир. Нутқда улар сўзловчи томонидан тингловчининг ёши, жинси, қариндошлик белгилари асосида танланади. Хар иккала тилда хам баъзан нотаниш кишиларга нисбатан хам қариндошлик ифодаловчи сўзлар мурожаатда қўлланилади. Бунда асосан тингловчининг ёши ва жинси инобатга олинади. Корейс дискурсининг гендер тафовутлари қариндошлик терминлари билан ифодаланган мурожаат бирликларида яққол намоён бўлади. Таржима жараёнида корейс тилида бир сўз билан берилган мурожаат бирликлари ўзбек тилига таржима қилиниш жараёнида баъзида икки сўз билан, баъзида эса учта сўз билан хам берилиш холатлари кузатилади. Бу холат хар бир тилнинг ўз хусусиятидан келиб чиқган холда юзага келади. 


\section{Адабиётлар:}

1. Ким Г. О категории обращения в речевом этикете в корейском языке. 23.08.2004

2. Усмонова Ш. Корейс ва туркий тилларда ундалмалар // Тилшуносликнинг долзарб масалалари. -Тошкент: “Университет”, 2004.

3. Усманова Ш. Ўзбек ва корейс тилларидарасмий мурожаат шакллари//

Лингвист / Илмий мақолалар тўплами. III. - Тошкент: 2012.

4. 이무영. 예절바른우리말호칭.. 서울출판사. 2005.

\section{RUHIY HOLATNI IFODALOVCHI FE'LLI FRAZEOLOGIK BIRLIKLARNING AYRIM XUSISIYATLARIGA DOIR}

\section{Doliyeva Laylo Bo'riboyevna SamDCHTI o'qituvchisi E-mail : doliyeva@samdchti.uz}

Annotation: This article presents research on some features of verb component phraseological units in the expression of mood. Various manifestations of the human psyche are analyzed in units of joy, anger, fear, and amazement.
Key words : Phraseological unit, experiences, feelings, verb, central meaning, action verb, state verb.

Til inson his-tuyg'ularini ifodalashning eng samarali usullaridan biridir. U shunday xususiyatga ega bo'lganligi uchun ham inson tuyg'ularini "boshqaraoladi"- uning qalbida turli kechinmalar, hissiyotlar paydo qilaoladi. [1. P.88]

V.P. Belyanin " hamma joyda - fonetikada, morfologiyada, leksika va semantikada, hatto ritmika, vazn va musiqada - grammatik va shakliy kategoriyalar ortida psixologiya yashiringan!" [2. C. 8.]- degan fikrni ilgari suradi.

Insonning ruhiy holati, his-tuyg'ulari uning nutqidaanglashiladi. Nutqning ta'sirchanligini, emotsionnalligini oshirishga hizmat qiladigan so'zlar ham, frazeologik birliklar ham o'z ma'nolari bilan inson psixikasiga ta'sir etish xususiyatiga ega.

Insonnning ruhiy holatini ifodalovchi fe'l kompanentli frazeologik birliklar fransuz tilida ko'pchilikni tashkil qiladi va ular insonning turlicha ruhiy holatini ifoda etaolishi bilan xarakterlanadi. Quyida ularning bazilarini keltirib o'tamiz.

\begin{tabular}{|c|c|}
\hline Ruhiy holat & Misollar \\
\hline $\begin{array}{c}\text { Quvonch } \\
\text { va } \\
\text { xursandchilik }\end{array}$ & $\begin{array}{l}\text { bondir de joie - quvonchdan sakramoq } \\
\text { etre aux anges -boshi ko'kka yetmoq } \\
\text { sourire jusqu'aux oreilles - og'zi qulog'ida bo'lmoq } \\
\text { déborder de joie - quvonchi toshmoq } \\
\text { êre gai comme un pinson - juda ham xushchaqchaq bo'Imoq } \\
\text { eclater de joie- quvonchdan porlamoq } \\
\text { rayonner de bonheur - baxtdan porlamoq } \\
\text { avoir le coeur leger - yengil tortmoq, xotirjam bo'Imoq }\end{array}$ \\
\hline Jahl va g'azab & $\begin{array}{l}\text { avoir la moutarde qui monte au nez - achchig'i chiqib boshlamoq } \\
\text { sortir de ses gonds - qoni qaynamoq } \\
\text { faire les gros yeux-ko'zlari kosasidan chiqay demoq } \\
\text { etre fou de rage -g'azabdan quturib ketmoq } \\
\text { fumer de colere - fig'oni falakka chiqmoq } \\
\text { piquer de colere -jahli qo'zg'amoq }\end{array}$ \\
\hline Qo'rquv & $\begin{array}{l}\text { avoir les mains moites - qo'llari terlamoq } \\
\text { avoir des sueurs froides - sovuq ter chiqmoq }\end{array}$ \\
\hline
\end{tabular}




\begin{tabular}{|c|l|}
\hline & $\begin{array}{l}\text { devenir blanc -oqarib ketmoq } \\
\text { être plus mort que vif -o'lgandan battar bo'Imoq } \\
\text { rester cloue sur place -joyida mixlanib qolmoq } \\
\text { se faire tout petit -hammasini maydalashtirmoq }\end{array}$ \\
\hline G'amginlik & $\begin{array}{l}\text { avoir une boule dans la gorge -tomog'ida talqon saqlamoq } \\
\text { avoir la gorge serre - tomog'i siqilib qolmoq } \\
\text { eprouverdechagrin -azobchekmoq } \\
\text { fondreenlarmes, enpleurs -ko'zyoshlariquyilibkelmoq } \\
\text { pleurer comme une madeleine - zor-zor yig'lamoq }\end{array}$ \\
\hline Hayratlanish & $\begin{array}{l}\text { en rester bouche bée -og'zini ochib qolmoq } \\
\text { rester sans voix -ovozi chiqmay gapirolmay qolmoq } \\
\text { tomber des nues -osmondan tushgandek angrayib qolmoq }\end{array}$ \\
\hline
\end{tabular}

Yuqoridagi ruhiy holatni turlicha ifoda etadigan fe'l kompanentli frazeologik birliklarni tarkibiga e'tibor berilsa, fe'llar holat ve harakat fe'llarining ot va sifat bilan birikib kelib, umumiy inson ruhiy holatini ifoda etib kelayotganligini ko'rishimiz mumkin. Bunda, nafaqat fe'l balki, u bilan birga ishlatilgan so'z turkumlar umumiy ma'no hosil qilinishigaasos bo'lib hizmat qilyapti.

Fe'llar bilan birga qo'llanilgan so'zlar va birikmalar qanday holatni ifodalashiga ko'ra quyidagicha ko'rib chiqish mumkin.

Quvonchli ifodalovchi frazeologik birliklar tarkibidagi kompanentlar orasida keng qo'llaniladigan so'zlar joi, bonheur, coeur leger, ange, pinson kabi so'z va so'z birikmalarni kiritishimiz mumkin.

G'azabni ifodalovchi frazeologik birliklar tarkibida gros yeux, rage, gond, coler kebilar keng qo'llaniladi. Qo'rquvni tasvirlash jarayonida esa main moite, soeur froid, blanc kabilarni kiritishimiz mumkin. G'amginlik ham o'z navbatida chagrin, larme, pleur, gorge serre kabi so'z va so'z birikmalarining holat va harakat fe'llari bilan qo'llanilib umumiy g'amni ifoda etish hollatlari keng uchraydi. Hayrat ruhiy holatini ifodalovchi frazeologik birliklar tarkibida bouche bee, sans voix kabi birikmalar qo'llaniladi.

Odatda, holat fe'llari frazeologik birlik kompanenti sifatida qo'llanilganida markaziy ma'noni sifat va ot birikmalari xosil qilib keladi deyish mumkin.

\section{Rester sans voix -ovozi chiqmay gapirolmay qolmoq}

Tomber des nues -osmondan tushgandek angrayib qolmoq

Rester va tomber fe'llari holat fe'llari xisoblanadi, bu yerda umumiy ma'noga sans voixovozi chiqmay, des nues-ko'k, osmon so'zlarining ta'siri sezilarli bo'lganligini kuzatishimiz mumkin. Frazeologizmlar, boshqa so'zlar singari, fikrlarni yetkazishga, voqelik hodisalarini aks ettirishga xizmat qiladi. Ularning asosiy ahamiyati ifoda uchun hissiy rang berish, uning ma'nosini mustahkamlashdir. Agar to'g'ri ishlatilgan bo'lsa, ular nutqni maxsus ekspressivlik, aniqlik va tasvir bilan ifodalashga yordam beradi.

\section{Adabiyotlar :}

1.Farzad Sharifian. Cultural Conceptualisations and Language. Amsterdam, Philadelphia 2011.

2.Белянин В.П. Основы психолингвистической диагностики (модели лира в литературе). - М.: Тривола, 2000.

3.González R. I. La phraséologie du français. -Toulouse : Presses Universitaires du Midi, 2015. (1re éd. 2002). 


\section{АНТОНИМИЯ ХОДИСАСИДА "НОН" ЛЕКСЕМАСИНИНГ ИШЛАТИЛИШИ}

\section{Ибатова Амира Шавкатовна ТАТУ Самарқанд филиали ассистенти E-mail : amira ibatova@mail.ru}

Annotation: The article covers the phenomenon of grouping of language ts according to their mutual opposite meanings, that is, the use of the "bread" ?me in the case of antonyms and the phenomenon of antonyms. Also, one of the iortant functions of the language is the naming of something in existence-an item, event, an action, a condition, a character, a feature, a quantity, a person, etc. And : task is performed through lexical units. Lexical units are directly or indirectly nected with the subject in the being according to their meaning.
Key words : antonym pair, lexeme, contextual antonym, enantiosemia, logical center, lexical antonomy, lexical units.

Мамлакат ижтимоий-иқтисодий хаётини ривожлантиришда таълим сохасини ривожлантиришнинг сиёсий омиллари қаторида Президентимиз Шавкат Мирзиёевнинг “Эркин ва фаровон, демократик Ўзбекистон давлатини биргаликда барпо этамиз” асарида ёритилган жамиятимиз хаётини барча сохалардаги жараёнларни ривожлантиришнинг устувор йўналишлари мохиятидан келиб чиқиб олиб бориш хозирги кундаги долзарб масалалар сифатида эътироф этилади.

Мустақиллик миллий қадриятлар қаторида она тилига янгича муносабатни шакллантирди. Миллий тилимизнинг ижтимоий мавқейи, давлат тили сифатидаги мақоми, ижтимоий-сиёсий хаётдаги нуфузини юксалтирди.

Ўзбек тилшунослигининг янги босқичга кўтарилиши учун кенг йўл очди. Айниқса, тил ходисаларининг миллий табиати, ўзига хос хусусиятларини ўрганишга йўлбошчилик қилди. Бу вазифа эса лексик бирликлар орқали амалга оширилади. Лексик бирликлар ўз маъносига кўра борлиқдаги предметлар билан бевосита ёки билвосита боғланади. Хар бир предмет ёки ходисанинг антиподлари мавжудки, бу, албатта, тилларда ўз аксини топиши турган гап. Масалан, Tag und Nacht, alt und jung, reich und arm, gross und kleinва бошқалар[2] .

Тил бирликларининг ўзаро зид маъноларни англатишига кўра гурухланиши ходисаси антонимия дейилади. Антонимия - лексемаларнинг бир-бирига зид маъно англатиши асосида гурухланиши. Антонимик жуфтлик - ўзаро қарама-қарши маъноли икки сўз. Контекстуал антонимия - тилда антонимик муносабатда бўлмаган сўзларнинг маълум контекст доирасида антонимик муносабатга киритилиши. Энантиосемия - битта лексема маъносида нутқий мухит тақозоси билан зидланишнинг ифодаланиши. Мантиқий марказ - икки маъно ўртасидаги оралиқ тушунча. Лексик антономия - лексемаларнинг бир-бирига зид маъно англатиши асосида гурухланишидир: оқ нон ва қора нон, қалин нон ва юпқа нон каби.

Антономия ходисаси, асосан, бир сўз туркуми лексемалари доирасида юз беради. Сифатларда: а) хажм белгисига кўра: катта нон ва кичик нон, қалин нон ва юпқа нон; б) харорат белгисига кўра: иссиқ нон ва совуқ нон; в) шакл белгисига кўра: тўғри нон ва эгри нон; г) маза-таъм белгисига кўра: тузли нон ва тузсиз нон; аччиқ нон ва ширин нон каби. Пайт, холат, миқдор, мақсад маъноли лексемалар доирасида хам антонимия ходисаси кенг тарқалган: а) кечаги нон ва эртанги нон, аввалги нон ва кейинги нон (пайт белгисига кўра), б) кўп нон ва оз нон, мўл нон ва кам нон (миқдор белгисига кўра) ва б.лар. Бундай лексемаларнинг сифат ва равиш туркумига мансублиги кейинги йилларда бир қадар мунозарали бўлиб қолмоқда. Баъзан феълнинг сифатдош шакли сифат туркумидаги лексема билан антонимик муносабатларга киришиши мумкин. Антонимия ходисаси сифат туркумида кенг тарқалган, от ва феълларда бир оз камроқ учрайди, олмош ва сонларда эса бўлмайди (айрим контекстуал холатлар бундан мустасно). 
Лексик антонимия иккита лексема орасида юз беради, бу икки сўз антонимик жуфтликни хосил қилади, аммо антонимик жуфтлик жуфт сўз деган гап эмас. Қиёс қилинг: катта нон ва кичик нон - антонимик жуфтлик (ундаги хар бир сўз-мустақил лексема), катта нон - кичик нон - битта жуфт сўз, у умумлашган битта маънога эга. Демак, катта нон ва кичик нон зид маъноли иккита лексема бўлганлиги учун улар бир-бирига нисбатан антонимлардир, катта-кичик жуфт сўзи эса антонимлар иштирокида ясалган битта лексемадир, бинобарин, битта лексеманинг ёлғиз ўзи антоним хисобланмайди.

Антонимия ва полисемия ходисалари ўзаро боғлиқдир: кўп маъноли лексема ўзининг бош маъноси билан битта антонимик жуфтликка, хосила маъноси билан эса бошқа антонимик жуфтликка кириши мумкин. Масалан: аччиқ нон ва ширин нон бирикмаларида аччиқ ва ширин лексемалари ўзларининг бош маънолари орқали антонимик муносабатга киришган; аччиқ гап ва ширин гап бирикмаларида эса аччиқ ва ширин лексемаларининг хосила (кўчма) маънолари антонимияга асос бўлган [6,79] .

\section{Адабиётлар :}

1.Мирзиёев Ш.М. “Эркин ва фаровон, демократик Ўзбекистон давлатини биргаликда барпо этамиз” Т: "Ўзбекистон", 2016 йил.

2.Бушуй А.М. О фразеографической концепции Мухтара Умарходжаева // Хорижий филология, Самарканд. 1(30), 2009, - С. 19.

3.Мирсаидов А. Ўзбек тилидаги миллий-маданий лексик бирликларни инглиз тилига таржима муаммолари // Замонавий тилшунослик ва лингводидактиканинг коммуникатив аспектлари. Республика илмий-амалий анжумани материаллари. - Самарқанд, 2019.

4.Рустамова Д. Лисоний қиймат ва уни тиклашга доир // Тилшуносликнинг долзарб масалалари. ВИ.

- Т.: Академнашр, 2012.

5.Умархўжаев М.Е. Олмон тили лексикологияси ва фразеологияси. Андижон, 2010. - Б. 79.

6.Усмонов. О. - Умумий тилшунослик. Олиймактаб. 1972.

\section{THE INTERACTIONS OF LANGUAGE AND CULTURE}

Islamova Guzal Tulkunovna

National University of Uzbekistan, teacher

Annotation: $\quad$ We live in an already changed world, when history, culture became a commodity, and we must live by the laws of the market. In the context of globalization and acute geopolitical struggle, it is necessary to make history, culture, the property of the widest sections of our society. Culture helps people live, maintain their identity and adequately respond to the challenges of external forces.
Key words : culture, intercultural communication, languages, national characteristics, ways of behavior and thinking, cultural tradition of various societies.

"Language is a roadmap of culture. He will tell where his people came from and where they are going." Rita May Brown

In the process of development of the modern world in line with interconnectedness and integrity, the pace of global integration of the material and spiritual culture of various countries is constantly increasing, which stimulates the intensive expansion of the areas of intercultural communication among members of the world community, deepening the content of their cooperation. Intensive internationalization and integration of various aspects of the life of states made the role of foreign languages as a means of intercultural communication the most significant. The influence of the cultural context on personality formation cannot be overestimated.

In the 21st century, the language of interhuman communication is the language of culture - the general culture of the individual, the culture of international cooperation, and the culture of society as a whole. 
Language is a self-developing phenomenon, i.e. Many people create a language, but at the same time, people cannot change their language at their whim.

Culture is associated with the active participation of man, it is created by people, it develops under the influence of new theories, new phenomena of reality (for example, the 21st century, the age of high technology, is changing human culture: lifestyle, art, structure of society, family relations,

etc.).

Language is the property of any person; the mass character of language as a phenomenon is completely natural. While in culture, elitism (selectivity) is valued. Although it must be said that the culture of the 21st century is largely created for the mass consumer, which, nevertheless, does not reduce the high value and appreciation, for example, of elite works of art. At the same time, language is an integral part of the culture that we inherit, the main instrument of cognition and assimilation of culture. The comprehension of science, religion, literature is possible only through language and through language.

Language and culture are closely connected with the processes of communication (communication of people), with the formation of a person's personality, as well as of society as a whole.

The concept of "culture" is used to characterize the material and spiritual level of development of certain historical eras, socio-economic formations, specific societies, nationalities and nations (for example, ancient culture, Mayan culture), as well as specific areas of activity or life (work culture, art culture, culture of life). In a narrower sense, the term "culture" refers only to the sphere of people's spiritual life. In cultural studies, there are a number of approaches developed by domestic and foreign scientists. "In human development, there are, as it were, two intertwined lines.

The first follows natural maturation. The second is to master the culture, ways of behavior and thinking. Auxiliary means of organizing behavior and thinking (that is, mastery of culture) are systems of signs and symbols that mankind created in the process of historical development, that is, language, writing, etc."

The language also reflects the national characteristics of each nation (its mentality).

There are theories based on the following position: language determines the way of thinking of the people speaking it. So, for example, the peoples of the north have a lot of words that indicate a phenomenon like snow. As we know, in Russian there is only one word for this. From the existence of such facts, it is concluded that different peoples see the same objects in different ways, the same world.

It is believed that every nation has the so-called keywords (they are most often used, used in proverbs and sayings), which reflect the spirit of the people. For example, for German culture, these words are:

attention, order, accuracy.

So, language is an original system, which leaves its imprint on the consciousness of people who speak it, forms their picture of the world.

Accordingly, language is a universal means of cognizing culture. The degree of development of language proficiency indicates the level of "cultural" personality. We also note that knowledge of several languages significantly expands a person's ability to know culture, the perception of one and the same phenomenon (subject) becomes multi-aspect, according to the linguistic and cultural tradition of various societies. The more languages a person speaks, the more adequate his perception of a certain cultural phenomenon.

It is customary to divide culture into material and spiritual, respectively, to the two main types of production - material and spiritual. Material culture covers the entire sphere of material activity and its results. Spiritual culture is a part of the general personality culture. Spiritual culture is a diverse system of knowledge, states of the emotional-volitional sphere of the psyche and thinking of individuals, as well as the immediate forms of their expressions signs. The universal sign - language - natural, artificial, sound (speech) and written. 
How are language and culture connected, and is it possible to study culture through language and language, relying on culture? Introduction to spiritual values reflected in the language and literature being studied (materials of folklore, texts, etc.) means entering a different culture, since in science the problem of the unity of language and culture, language and society is considered to be resolved. Language is the guardian of national culture, therefore, a foreign language should be taught not only as a way of expressing your thoughts, feelings, but also as a source of information about the culture of the people. The word is a universal tool for understanding and perceiving spiritual values.

In the process of developing the modern world in line with interconnectedness and integrity, the pace of global integration of the material and spiritual culture of various countries is constantly increasing, which stimulates the intensive expansion of the areas of intercultural communication among members of the world community, deepening the content of their cooperation. Intensive internationalization and integration of various aspects of the life of states made the role of foreign languages as a means of intercultural communication the most significant.

The influence of the cultural context on personality formation cannot be overestimated. In the 21st century, the language of interhuman communication is the language of culture the general culture of the individual, the culture of international cooperation, and the culture of society as a whole.

The concept of "culture" is used to characterize the material and spiritual level of development of certain historical eras, socio-economic formations, specific societies, nationalities and nations (for example, ancient culture, Mayan culture), as well as specific areas of activity or life (work culture, art culture, culture of life). In a narrower sense, the term "culture" refers only to the sphere of people's spiritual life.

Language is the guardian of national culture, therefore, a foreign language should be taught not only as a way of expressing your thoughts, feelings, but also as a source of information about the culture of the people. The word is a universal tool for understanding and perceiving spiritual values. A number of sciences are engaged in the interconnections of language and culture, language and society: linguistics, sociology, sociolinguistics, psychology, psycholinguistics, linguodidactics, ethnolinguistics, ethnopsycholinguistics.

\section{References:}

1. Andersson, S. (2004). Growing Up with Two Languages: A practical guide. London, UK: Routledge.

2. Barron-Hauwaert, S. (2004). Language Strategies for Bilingual Families: The one-parent one language approach. Clevedon, UK: Multilingual Matters.

3. De Houwer, A. (2006). The Acquisition of Two Languages from Birth: A case study. New York, NY: Cambridge University Press.

4. Kroll, J.F., \& A.M.B. De Groot. (2005). Handbook of Bilingualism: Psycholinguistic approaches. Oxford, UK: Oxford University Press.

5. Ting-Toomey, S. (1999). Communicating Across Cultures. New York: The Guilford Press

カラカルパク語「alıw」と日本語「取る」の共通点と相違点 (qoraqalpoq tilidagi [alıw] va yapon tilidagi [olmoq] ning o'xshash va farqli jihati)

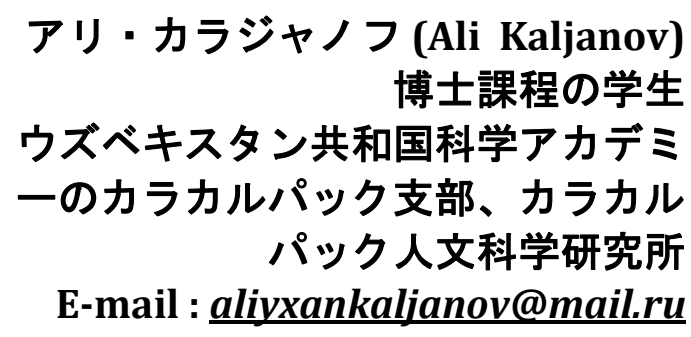


Annotation: This article compares the words (take) in Karakalpak language and Japanese. In this case, the words (take) are compared in general and abstract meanings.

Key words :

Karakalpak language, alıw，「取る」

外国語を学習する時、言語学習者は目標言語の文法を母語言語と比較する。様々な 言語の発音、単語の用法、文の構造などが異なると同じように文法も違う。

日本語は世界で一番難しい言語の一つと言われている。日本語を学ぶのには多くの 時間が掛かる。しかし、日本語とカラカルパク語は似ているところが多い。例えば、語順 は同じである。また、両言語の文法に共通点も多い。例、

私は タシケントで 勉強している。

Men Tashkentte oqip atırman. と翻訳できる。

日本語の主な述語部分は動詞である。日本語とカラカルパク語の動詞の辞書形の音 響も同じである。例えば、反る「soru」と「soriw」である。日本語では一つの言葉に 多くの読み方があり、また、同音異義語も多い。一つの言葉に多くの意味があるという言 葉も多い。たとえば、日本語で「取る」という動詞には多くの意味がある。小学国語辞典 ではでは 10 の意味があり、他の集英社国語辞典では 30 の意味があるということである

日本語とカラカルパク語は似ているところもあるが、あまり似ていない、全く違う という場合も多い。例えば、「取る」を訳する時、あるいは、その動詞を使う時である。 日本語を勉強し、日本語の困難さに苦労したことがあり、特に「取る」という動詞を理解 するのは難しかった。「取る」はカラカルパク語で「alıw」と翻訳される。考えてみると ある程度日本語の「取る」はカラカルパク語の「alıw」に似ているかもしれないが、しか し、実際の会話の場面でそれらの違いがよく見立つ。

日本語は世界で広がる言語である。多くの国で日本語は勉強されている。日本語に は多くの言語の辞典や教科書などはある。例えば、和英辞典、和露辞典などである。しか し、今まで日本語とカラカルパク語の関係がある辞典や教科書や記事はない。

その上、誰も日本語とカラカルパク語について研究していなかった。その理由の一 つは日本語を勉強しているカラカルパク人の人口数が非常にすくないためである。二つ目 の理由はカラカルパクスタンでは日本語に興味があまりなく、あるいは、人気がない。そ こで筆者は日本語とカラカルパク語に関して研究を始めたいと思った。

そのため、言語の最小単位と言われている単語から研究を始めたいと思う。また、 本研究は日本語とカラカルパク語の初めての研究なのでいわば卵である。将来、カラカル パク語と日本語の研究したい研究者のために先行研究として残したいと思う。そのためカ ラカルパク語と日本語の対照研究をしたいと思い、このテーマを選んだのである。

「取る」という動詞の意味は他の動詞より多い。日本語辞典では「取る」という動 詞の意味の数は様々である。例えば、小学国語辞典では $10 、$ BasicEnglishJapaneseDictionary では 13 、学研国語大辞典では 8、国語大辞典では 12 、集英社国語 辞典では 30 、日本語基本動詞用法辞典では 19 の意味がある。これは日本語学習者にお いて非常に難しい。

特に、「取る」という動詞の抽象的な意味での使い方は勉強するのが難しい。なぜな らば、日本語の辞書では「取る」の抽象的な意味はほとんど書かれていない。多くの辞書 では「取る」の「時間を取る」と言った簡単な単語だけ書かれていて、他の使い方が書 かれていない。そのために、学習者は抽象的な意味で「取る」を使うときよく間違える。 あるいは、「取る」の変わりに「もらう」「受ける」と言う言葉を使って間違える。例えば

「知識をもらう」ではなくて 「知識を取る」になる。また、「受ける」「もらう」の 変わりに「取る」を使ってよく間違える。例えば、「インスピレーションを取る」ではな 
くて 「インスピレーションを受ける」になる。学習者は「取る」の多くの意味があるか ら分からないで使ってしまって不自然な日本語になってしまう。いくらくらいの抽象的な 言葉がカラカルパク語と同じだろうかを知りたい。このような問題点を明らかにするため に先生方にインタービューする。

本研究の目的は「取る」と「aliw」の抽象的な意味の使い方を調べることによって 共通点と相違点を明らかにして、カラカルパク語から日本語への翻訳を簡単にしたい。そ の共通点と相違点を明らかにするにはよく理解しなければならない。そのため、学習者が より理解できるようにこれより「取る」と「aliw」の共通点と相違点を場面で挙げる。

今までなされた研究の中でカラカルパク語と日本語の対照研究はない。これは本研 究の先行研究がないということだ。しかし、その研究に近い、あるいは、他の言語と比べ る研究がある。岡 良和の「動詞take を非中心的直示動詞とみなすことに対する考察」で は「take を非中心的直示動詞と捉えることには問題があることが明らかとなった。Take の意味を「持っていく、連れて行く」と丸暗記してしまう」と述べている。張麗の「二格 とデ格の交替について」では「とる動詞の二格とデ格の交替を考察する」と述べている。

「取る」動詞は様々な意味があり、頻繁に使われる動詞である。文脈によって意味を 解釈する必要がある。「取る」動詞の以下通りに意味がある。

1.（どこ・何から）どこ・何に何を取る必要のある物をもとの場所から移動して、一 時自分の手の中に収める。

用例 $\cdot$ 作例。

手に取って見る

手を取って「（1)直接に。(2)親切に」教える

手に手を取って「=(1)気脈を通じて。(2)同じ思いになって」

おかずを小皿に取る「＝分ける」

2. 何を取る（さしあたって）必要としないものを自分が努力してもとの場所から移動 する。

用例 ·作例

雑草を取る「=むしる」庭の雑草を取る

痛みを取る「=除く」のどの痛みを取る薬

腐った所を取る「＝捨てる」果物の腐った所を取る

必要経費を取った「二差し引いた」額

命を取る「＝殺す」

かたきを取る「＝（殺す。復讐（フクシュウ）する」

ネズミを取る「＝つかまえる」

眼鏡を取る「＝はずす」

帽子を取る「＝ぬぐ」

3.（何・誰から）何を取る自分の必要とするものをなんらかの方法で自分の物とする

用例 - 作例。

学位を取る

蕨を取る「＝自生しているワラビを折って来る」

食事を取る「＝食べる」

栄養を取る「＝栄養物を食べる」

嫁を取る「＝迎える」

師匠を取る「二誰かを師匠として何かを学ぶ

光を取る「＝導き入れる」 
金を取る「=(1)盗んだり奪ったりする。(2)一定の収入を得る。(3)月謝や料金などを徵収 する」

罰金を取る「＝出させる」

休暇を取る「＝もらう」

弟子（新卒）を取る「二採用する」

新聞を取る「二購読する」

注文を取る「＝受ける」

そばを取る「＝注文して、届けさせる」

どうかこれだけはお取りになって「＝受け取って」ください

取るものも取りあえず「二余りにも突然の事で何をどうするという心の余裕も無く、大急 ぎで」駆けつけた

天下を取る「＝支配する」

いい席を取る「＝予約する」

宿を取る「二宿泊する宿屋を決める」

車間距離を十分に取る「二保つ」

間合を取る「＝必要な間隔を保つ」

種を取って「＝たくわえて」おく

最後の切り札として取っておく「＝保存する」

4. 何を取る（手を）自分の思い通りに動かして、何かをする。

用例 $\cdot$ 作例

筆を取る「＝文章を書く」

事務を取る「二処理する」

指揮を取る「二指揮する」

写真を取る「＝写す」

ノートを取る「ニノートに筆記する」

穀類や果物から酒を取る「二つくる」

手拍子を取る「ニそろえる」

舵を取る「＝操って、船を進める」

型を取る「＝型に従って、それと同型の物を作る」

かるたを取る「＝して遊ぶ」

すもうを取る「=(1)自分でする。(2)して見せる」

床を取る「二延べる」

機嫌を取る「二取り結ぶ」

例に取る「＝取り上げる」

5. 何を取る自分の立場上、それを選ぶ。

用例 $\cdot$ 作例

名を捨てて実（ジツ）を取る

多数決を取る「＝主張する」

あえて僕の取らない「二選ぶことをいさぎよしとしない」所だ

君のために取らない「＝君がそのような $\Delta$ 手段（行動）に従う事を良いこととは思わない $」$

取るに足らぬ「＝問題にするだけの価値が無い」

6. 何を取る実際に調べて、内容を判断したり理解したりする。

用例 - 作例。

脈を取る「二(1)はかる。(2)診断する」

尺を取る「＝何尺あるか、計測する」 
丁合（チヨウアイ）を取る「=丁丁合」

出欠を取る「=出欠を実際に調べる」

先方の申し出をいい意味に取る「二解釈する」

7. 何を取る何かをするのにそれだけのものを必要とする。

用例 - 作例。

場所を取る「＝占める」ので困る

時間を取る「二費やす」

手間を取る「=(1)時間・手数がかかる。(2)手間賃を得る」

8 . 何を取る $\Delta$ やむを得ず（行きがかり上）そういう結果を得る。

用例 - 作例。

不覚を取る

污名を取る

ひけを取る

年を取る「＝重ねる」

責任を取る「＝自分で引き受ける」

仲介の労を取る「＝自分が仲介してやる」

上のように「取る」動詞の意味は様々である。そのために「取る」動詞を勉強するとき 大きな問題が出て来る。

一ロで言えば、カラカルパク語の「aliw」動詞は「取る」およそ同じである。Aliw は

「取る」「獲得する」「持っていく」「受け取る」「かかる」「撮る」など意味を表す。 Alıw の過去形は aldı、過去分詞は alǵan である。「alıw」動詞は様々な意味があり、頻繁 に使われる動詞である。文脈によって意味を解哷する必要がある。ここで基本的によく使 われる意味での例文である。

Qálegennárseńdial 必要な物は何でも持っていって。

Háritimalǵa qarsı zontigińdi alıpjúreber. もしもの為に、傘を持って行きなよ。 Awqat pisiriwtek ǵana 5 minuttı aladı. それはたった 5 分かかるだけで調理出来る。

Tuwrı zattı ańlawushınanaǵurlımwaqıttı aladı. 何が正しい事か気づくのには少し時間がか かるかもしれない。

Men búgin demalajaqpan今日は一日休みを取っている。

Menonı artıq ala almaymanこれ以上我慢は出来ない。

Meniytimdiveterenarǵaalıpbarajaqpan 私は飼い犬を獣医に連れて行く。

Men keyingi birneshe jıllıqta berli hár kúni dem alaman. ここ数年、私は毎日昼寝をして いる。

[alıw]はとても活用範囲の広い単語で、辞書を引いてみると覚えきれないほどの意味や例 文が出てくる。

以下はカラカルパク語の「alıw」の意味である。

1。手などで取る。

彼は本を取った。Ol kitap aldl.

2. (わな・えさなどで)〈鳥獣を〉捕らえる; 〈犯人などを〉捕縛する，捕虜にする.

マスを 3 匹つかまえる úsh kapusta alıw

人をとりこにする adamdı tutqınǵa alıw

とりでを奪取する qorǵandı basip alıw

3.「賞などを」獲得する，手に入れる，取得する

学位を取得する dáreje alıw

彼は先週 600 ドルを稼いだＯl ótken hápte 600 dollar aldı.

4.「ものを」買う. 
この帽子をください.

Men bul shlyapanı alaman.

5.「人を」採用する;「弟子を」取る; 「下宿人を」置く; 「妻を」めとる. 弟子を取る. Oqıwshılardı alıw

彼をそのグループに加えた

Bizleronı guruppaǵaalıpkirdik.

6.「手段などを」講じる.

方策を講じる Ólshemlerdialıw

7.「専門家の意見を」求める, 聞く

医師の診察を受ける medecinalıq másláhatalıw

8.[…を][…から]引用する、借用する。

この行はシェイクスピアから引用されている。Ｂul qatar Shekspirdan alıngan.

日本語の動詞もカラカルパク語と同様、動詞に接尾辞を付けて時差を表すが、カラカ ルパク語の場合人称語尾が伴っている。動詞の行為者が明確に示されるため、しばしば主 語は省略される。

日本語の「取る」動詞をカラカルパク語に翻訳された時多くの違いが起こる。つまり、 「aliw」の変わりに他の言葉が来る。たとえば、「朝食を取る」という文は「shayqalqas alıw」にならない。この文は「shayqalqas quliw」と翻訳される。

「取る」という動詞をカラカルパク語での「alıw」と翻訳できる。「取る」と「「aliw 」の共通点見て見る。

手に持つ。

本を取る。kitap alıw

ある物を手に持って渡す。

あの棚の上の本を取ってくれませんか polkadaǵı anaw kitaptı alıp beresizbe?

得る。受け取る。

注文を取る buyriq aliw

これから、違うところ見て見る。

利息を取る qlzıǵlw

元を取る kapitaldı qolǵa kirgiziw

上の見ると「取る」意味は「aliw」ではなくて、ほかの言葉がくる。

日本語の「取る」と カラカルパク語の「aliw」動詞のよく比べるために以下の通り に形である。

\begin{tabular}{|c|c|}
\hline 取る & Alıw \\
\hline 取った & alǵan \\
\hline 私は取りました & Men aldım \\
あなたは取りました & Sen aldıń \\
彼・彼女は取りました & Ol aldı \\
私たちは取りました & Bizler aldıq \\
あなたたちは取りました & Sizler aldıńız \\
彼ら・彼女らは取りました & Olar aldı \\
\hline 取って & Alıp \\
\hline 私は取りたい & Men almaqshıman \\
\hline 取らない & Almayman \\
\hline 取らなかった。取りませんでした。 & Almadım \\
\hline
\end{tabular}


以下、「取る」と「alıw」を比べた 場合。

場を取る

なを取る

手を取る alıw

あくを取る suyı～zattıń kóbigin alıw

手間を取る joldan qaldırıw, uslap turiw

引けを取る artıq bolıw, ústin keliw，

床を取る

birewdiń

tóseginsalıpberiw

裏を取る dáliltoplaw

舵を取る

juwapkershiliktimoynınaalıw

段を取る alıw

暖を取る

意味を取る

中を取る

jumıs islew

年を取る

城を取る

alıw

銀を取る qulıw

決を取る

幅を取る

orın alıwı

主を取る

指揮を取る

控えを取る

場所を取る

形を取る

不覚を取る

kúshlijeńiliskeqıynalmaw,

涼を取る

zawıq alıw

脈を取る

帽子を取る

賞を取る

間を取る

立場を取る

笑いを取る

先手を取る suwiq samaldan

birewdi jılıtıw

mánisin uǵıp alıw

óz ara kelisip

qartayıw

saraydı qolǵa

alıp taslaw , joq

dawıs alıw

birewdiń úlken

tazaustatabıw

baǵdarberiw

nusqasınalıw

orinalıw

formasınalıw

pulsin alıw

bas kiyimin alıw

siylıq utıp alıw

ortasin alıw alıw

尺を取る ólshemin alıw

大事を取る birnárse

islewde diqqatlı bolıw

機会を取る

imkaniyat

alıw

同期を取る

bir-birine

maslastırıw

切符をとる

aldın ala

bilet satıp alıw

態度を取る pikir

alıw

アールを radiusin alıw

バランスを取 balanstı saqlaw

音頭を取る

adamlar

toparın basqarıwdı qolǵa alıw

予約を取る

ushirasıw

機嫌を取る

maqtaw

esitiw ushın háreket etiw

挙げ足を取る birewdi ayıplı dep tabiw

調子を取る

waqittan

utıw, waqit belgilew

死に水を取る qaytıs bolayın dep atırǵan adamǵa itibar beriw 取り舵を取る porttı basqarıw 対数をとる

logorifimın alıw

連絡を取る bir-

birinen xabar alıw

食費を取る birewge

awqat alıw

責任を取～juwapkershilikti moynına alıw

教鞭をとる

oqitatuǵın jumıs alıw

$\begin{array}{lr}\text { 重心を取 } & \text { tártiplestiriw } \\ \text { 出欠を取る } & \text { dizim }\end{array}$

alıw

休䪹を取る dem alıw

極限をとる sheklew 
上では日本語の「取る」（名詞十取る）の形でカラカルパク語の「alıw」と様々な意味 での使い方の共通点と相違点を見てみた。それによると「取る」と「alıw」の共通点は多 いということが分かった。

筆者は本研究では日本語とカラカルパク語の比 較する時様々な問題が起こる。その一つは抽象的な意味で比較する。カラカルパク語の「 alıw」と日本語の「取る」の抽象的な意味範囲で同様なところもあり、違うところもある 。これは人にとって手で取られないことを、あるいは、目に見えないことを取るである。 まず、同様なところを見る。例 :

時間を取る waqitalıw

知識を取る bilim alıw

天下を取る

意見を取る

学位を取る

名を取る

休みを取る

情報を取る

約束を取る

範を取る

誉れを取る kúsh alıw

pikir alıw

mártebe (dáreje) alıw

ism (at) alıw dem alıs alıw xabar alıw wádesin alıw órnek alıw dańq alıw
命を取る janın alıw

痛みを取る dártin alıw

注文を取る ruxsat alıw

光を取る nur alıw

間合を取る tánepis alıw

事務を取る is alıw

指揮を取る buyrıq alıw

機嫌を取る keypiyat alıw

養子を取る tárbiya alıw

今度相違点を見て見る。

\begin{tabular}{|c|c|c|}
\hline カラカルパク語で & 日本語で & 違う、使わない形 \\
\hline Diqqatın alıw & じゃまをする & 注意を取るではない \\
\hline Ǵárezsizlik alıw & 独立する & 独立を取るではない \\
\hline Kewil alıw & 心を盗む & 心を取るではない \\
\hline Sóz alıw & スピーチする & スピーチを取るではない \\
\hline Lázzet alıw & 楽しみにする。 & 楽しみを取るではない \\
\hline Úlgi alıw & 手本する & 手本を取るではない \\
\hline Ǵarǵıs alıw & 呪いをかける & 呪いを取るではい \\
\hline Razılıq alıw & 承諾を得る & 承諾を取るではない \\
\hline Sálem alıw & あいさつをする & あいさつを取るではない \\
\hline Gózzallıq alıw & 目の保養になる & 美しさを取るではない \\
\hline Tájiriybe alıw & 経験する & 経験を取るではない \\
\hline Tásir alıw & 影響する & 影響を取るではない \\
\hline Nátiyje alıw & 成果を得る & 成果を取るではない \\
\hline Imtixan alıw & 試験を受ける & 試験を取るではない \\
\hline Kúsh alıw & カにする & カを取るではない \\
\hline Alǵis alıw & 拍手掲采にする & 拍手掲采を取るではない \\
\hline Quwanısh alıw & 喜ぶ & 喜びを取るではない \\
\hline Járdem alıw & 後援を受ける & 後援を取るではない \\
\hline Imkaniyat alıw & チャンスを得る & チャンスを取るではない \\
\hline Ilham alıw & $\begin{array}{l}\text { インスピレーションを } \\
\text { 受ける }\end{array}$ & $\begin{array}{l}\text { インスピレーションを取るでは } \\
\text { ない }\end{array}$ \\
\hline Aqul alıw & 知識を得る & 知恵を取るではない \\
\hline Mehir alıw & 慈悲を受ける & 慈悲心を取るではない \\
\hline
\end{tabular}


以上では、カラカルパク語では「aliw」と使うが、日本語で「取る」と使わない言葉を 比べた。「取る」と「alıw」の抽象的な意味で比べると相違点が多いということが分かっ た。

「取る」と「alıw」動詞を抽象的な意味で比べると共通点と相違点が出て来る。学習者 は使い方での共通点と相違点を覚えると勉強しやすい。

本研究は日本語とカラカルパク語の初めての研究である。そのため、様々な問題が 出て来た。そして、本稿では弱い点があると思う。日本語の「取る」には多くの意味があ るが、カラカルパク語「aliw」の意味は少ない。その点は比較すれば大きな違いになった 。そして、抽象的な意味で比べると「取る」と「aliw」の共通点と相違点を明らかにした 。「取る」動詞の多くの意味を分析し、ほとんどの使い方を分かった。

また、「aliw」の意味をできるだけ書いた。抽象的な意味で比べると共通点より相違点 が多いと言うことを分かった。

本稿では「取る」と「aliw」動詞の「名詞十取る」 形で見てみた。多くの点で同じと いうこと分かった。しかし、「動詞十取る」形で明らかにしなかった。それを今後の課題 として研究したい。

THE ACTUALIZATION OF LINGUISTIC AND CULTURAL PECULIARITIES IN THE PROCESS OF COMMUNICATION

\section{Mavlyanov Ulugbek Saidkasimovich Lecturer in Humanities, Samarkand State Institute of Foreign Languages}

Annotation: The article discusses general trends and national-cultural features of communications, due to both internal language laws and extra -linguistic factors. Verbal and non-verbal means of communication are analysed, as well as problematic issues of differences in style, etiquette, behaviour and system of communication in different cultural contexts, barriers of intercultural communication are shown. It is in $t$ language and through the language that such important features and traits as national psychology, the character of the people, the way of thinking, the original uniqueness of artistic creation, moral state and spirituality are revealed. Culture also affects how people think and behave and leads to different understandings of vision and goals.
Key words : Language, Culture

Linguoculturolo gy, Culture of Speech, Communicatio, non-verbal communication. 
Introduction. Language is one of the most significant categories of culture, because through language a person's world understanding is formed and expressed. However, language is not only a means of communication, but also it is the environment in which a person is formed and lives, which determines the person's life experience.

Nowadays, the main function of a language is that it preserves the culture and passes it from generation to generation. That is why language plays such a significant role in the formation of personality, national character, people as well as nation.

Characteristic feature colloquial speech is emotionality, expressiveness, evaluation response.

In conversational speech big role plays verbal language is the natural form of expression of a person's thoughts cannot be neglected by non-verbal means. They play an important role in people's lives. There are various aspects of non-verbal communication. Gestures, facial expressions, body position and body movements of people can be interpreted in different ways. Work on gesture-mimic methods of communication showed that in the process of their assimilation it is necessary to carefully record the cases of interference of gestural-facial expressions used in the student's native language system.

Main part. At the junction of the study of culture and linguistics, a new science appears called "linguistic-culturology" that arose in the 90s of the XX century, also exploring the manifestations of people's culture, which are reflected and entrenched in the language. This is the development of a new scientific field that can overcome the limitations "Narrow departmental" study of facts and thereby provide a new vision and explanation. Therefore, this is not a temporary union of linguistics and cultural studies, but it is the interdisciplinary branch of science, independent. In its goals laid, objectives, methods and object of study.

The problem of the relationship of culture, language, ethnos is not new. At the beginning of the XIX century. German scientists, the brothers Grimm, tried to solve them, whose ideas found their development in Russia in the 60-70s of the XIX century. - in the works of F.I. Buslaev, A.N. Afanasyev, A.A.

With all the differences of the existing areas, the focus of the Contemporary linguoculturology is the study of the cultural semantics of language signs, which is formed by the interaction of the two different codes, i.e. language and culture, as each language identity is also a cultural identity at the same time. That is why language signs are capable of performing the function of the "language" of culture, which is expressed in the ability of the language to reflect the cultural and national mentality of its speakers. With this regard, we can talk about a "cultural barrier" that can arise even under conditions to comply with all language standards. An example is the case of an English conductor described by A. Vezhbitsky. When he was invited to lead the German orchestra. The work did not get along. The conductor thought it was due to the fact that he spoke English and the musicians did not accept him as "his." He started studying German, and the first thing he asked his teacher was how to say in German: "Look, I think it would be better if we played like this". The teacher thought about it, then he said: "Of course, it's possible to build a phrase like that, but it's better to say, "We should play it like that." Hence the conclusion: the cultural barrier is related to linguistic differences, and also to different values, which put the participants in the communication in seemingly the same words, with inadequate background knowledge, etc.

Communication is a process that involves at least two people: the speaker and the listener. In addition to the speaker and listener, who change roles during the communication and speech act, the subject of speech is necessary for communication to take place, what is being talked about and what is being exchanged, because this component is related to the knowledge of reality. Communication cannot take place if the subjects taking part in it do not know the language. A statement is born in communication. It contains everything that comes from the speaker about what he or she is saying to the listener in a language that they both know. 
Sometimes people must to pay attention for the condition of interlocutor, in order to avoid unwilling communication with him , for instance If a person sits on a bench in a park or rides in a bus, trolleybus, train A person that is next to him suddenly starts a conversation, the first man tries politely answered in one complicated way, making it clear that he doesn't want to maintain the conversation, however speaker could not understand gentle hint and pushes with questions, telling something. In this occasion All listener has to do is get up and change places or leave. And sometimes at home there is no desire to talk even with relatives, to answer questions, listen to their stories. There are different reasons for this: illness, fatigue, moping, a desire to focus on a case, to think about it. In such cases, we should remember about the culture of communication. There is no need to impose a conversation. Feel that the interlocutor does not show interest - stop talking, wait for the partner will need to communicate.

Any social activity is impossible without communication. In addition, there are activities that are based on communication. These are the activities of educators, teachers, lawyers, politicians, journalists, managers, and many service providers.

Conversation has its own norms that do not coincide in many cases with book norms, recorded in dictionaries reference books, grammars.

Another type of communication is non - verbal communication, that is the most popular in modern days. When talking, a person involuntarily follows the behaviour of the interlocutor. It is important where and how he looks. For instance, widely open eyes express interest, curiosity, attention. Cunningly pinched eyes - a sign of doubt, distrust. If the interlocutor feels uncomfortable, embarrassed, he tries to take his eyes aside. In addition to facial expressions, people unwittingly gesticulate when they talk. We have no idea how many different gestures a person makes when communicating, how often they accompany his speech. And what is surprising is that language is taught since childhood, and gestures are learned naturally, and although no one explains them beforehand, does not decipher their meaning, the speakers correctly understand and use them. This is probably due to the fact that the gesture is most often used not in itself, but to accompany the word, serves as a kind of support for it, and sometimes clarifies it.

Conclusion. At present, the common view is that the culture and language of each nation have both a universal and national component. Universal values, equally understood by all people in the world or by representatives of individual cultures, create the ground for intercultural communication, without which intercultural understanding would be impossible in principle. At the same time, any culture has specific cultural meanings enshrined in language, moral norms, beliefs, specific behaviour, etc. The above demonstrated link between language, thinking and culture is part of the semiotic approach to culture developed in the 20 th century, which considers culture as a set of signs and texts. The language of any nation is its historical memory embodied in the word. Millennial spiritual culture, people's life in a peculiar and unique way reflected language, in its oral and written forms, in the monuments of various genres - from ancient chronicles and epics to works of modern fiction. And that means culture language, word culture appears as an inextricable link of many generations.

\section{References :}

1. L.P.Stupin, K.S.Ignatiev .,Sovremennyi angliskiy rechevoy etiket, Leningrad,1980.-144p.

2. L.A.Vvedenskaya Kultura rechi. Seria "Srednee professionalnoe obrazovanie". - 5 izdanie -Rostov na Donu "Feniks",2004.-448p

3. V.V.Vorobiev. Linguoculturologya(teoria I metody) Monografia.-M.:Izdatelstvo RUDN,1997.-331p.

4. V.A.Maslova VVedenie v linguoculturologyu M.: Nasledie,1997.-207p. 


\section{ИНОСТРАННЫЕ ЯЗЫКИ \\ КАК ОСНОВА ИНТЕРПРЕТАЦИИ КУЛЬТУРНОГО НАСЛЕДИЯ}

\section{Мавлянова Тамилла Бахриллоевна \\ Преподаватель, Самаркандский Государственный \\ Институт Иностранных языков}

Annotation: This article is devoted to the study of the issues of teaching the close connection between the study of a foreign language and the interpretation of cultural heritage in this process. At present, one of the tasks in preparing a linguist or studying a foreign language is the formation of intercultural competence, the ability that allows a person to realize himself in the framework of a dialogue of cultures, that is, in conditions of intercultural communication. As a result of the research, the connection between culture and language was clarified, in addition, during the writing of this article, I formed the following statement: "Culture and language cannot exist without each other."
Key words : language, cultural heritage, linguoculturology, intercultural competence, scientific discipline, intercultural development, language training

Вводная часть. В настоящее время характерной чертой является усиление интеграционных процессов, которые в свою очередь охватывают экономику, политику, культуру, наукуиобразование. Изучение Культуры и формирование межкультурной компетенции в процессе изучения иностранного языка вносит значимый вклад в формирование многосторонне развитой личности в нашем многонациональном мире.

Защита и охрана природных богатств, здоровье народа осознаются теперь как важное общегосударственное дело. Охраняются и восстанавливаются памятники материальной культуры - часть духовного исторического наследия. Наш язык нуждается в таком же бережном подходе.

Процесс формирования опыта межкультурной компетентности считается пока не полностью раскрытой и это обусловливает недостаточность изученности характера соотношения процесса изучения иностранного языка с интерпретацией культурного наследия нации и народности которые являются коренными носителями данного языка.

\section{Основная часть .}

\section{Язык - это дорожная карта культуры. Он поведает, откуда пришли его люди и куда идут. Рита Мэй Браун}

В настоящее время большое внимание уделяется изучению иностранных языков, так как они стали играть важную роль не только в социальной сфере, но и в экономической, политической сферах. Как нам известно на данный момент по всему миру большинство государств стараются улучшить дипломатические отношения между собой и это в свою очередь приводит к нужде изучения иностранных языков. Если говорить об экономической жизни, то нужно отметить тот факт, что экономику многих государств поддерживает туризм, в частности если говорить о нашей стране большое внимание уделяется развитию туризма и увеличению кадров в этой сфере. На данный момент по нашей стране в образовательных учреждениях начиная уже с дошкольных учреждений, внедрено изучение иностранного языка. Всё это делается для того, чтоб расширить знания и мировоззрения нашей молодежи. К примеру, если говорить о Самаркандском государственном институте иностранных языков, существуют различные направления для изучения иностранных языков, а также в 2020-2021 учебном году планируют внедрить факультет с турецким наклоном.

Изучая иностранный язык, мы непосредственно также усваиваем культуру изучаемого языка, характерную для данной культуры менталитет, нравственные 
позиции, эстетические критерии, а также глубже осознаем свою национальную культурную принадлежность, и придаем значение месту в мировой культуре.

В современной жизни требованиями являются необходимость углубления содержания образования будущих преподавателей иностранного языка. Для преподавателя важным является осознать культуру изучаемого языка, стать единым с данной культурой, развить в себе те же творческие качества и быть способным к самоопределению.

Если говорить о программе подготовки кадров языкового вуза, определенно предполагают знание и умение применять в коммуникативной и профессиональной деятельности языковую интерпретацию данной культуры, это является явным доказательством того, что иностранный язык всегда ставится рядом с освоением культуры народов.

В современном мире активно развивается лингвокультурология - новая наука, исследующая проявление культуры народов, которые отразились и закрепились в языке.

Как отмечал В. В. Воробьев: « Лингвокультурология является комплексной научной дисциплиной синтезирующего типа, изучающая взаимосвязь и взаимодействие культуры и языка и отражение ее как целостной структурной единицы»

В ходе изучения иностранного языка, значимая роль отделяется изучению культуры стран говорящих на этом языке. Если говорить о французском языке, при его изучении студенты сталкиваются с освоением культуры не только самой Франции, но и с культурой франкоговорящих стран (Бельгия, Люксембург, часть Швейцарии и другие). Всё это говорит о том, что при изучении иностранного языка, мы истолковываем культуры стран говорящих на нем.

Существует высказывание: «Взаимосвязь языка и культуры оказывается движением в одну сторону; так как язык отражает действительность, а культура есть неотъемлемый компонент этой действительности, с которой сталкивается человек, то и язык - простое отражение культуры.»

Изучение иностранного языка оказывает очень большое значение в формировании мировоззрения и понятия культуры. Каждый язык хранит свою культуру и передавал её из поколения в поколение. Но на данный момент мы можем смело утверждать, что каждый изучающий иностранный язык может смело называть себя знатоком культуры данного языка. Вот поэтому говорят о важной роли языка в формировании национального характера, народа и нации.

В настоящее время стратегической целью овладения иностранными языками считается приобщение изучающего к другой культуре и его участие в диалоге культур. В ходе изучения иностранного языка, мы знакомимся не только с культурой, но еще и путем сравнения оттеняем особенности нашей национальной культуры, знакомимся с сущностью межкультурной компетенции.

Проблемой формирования межкультурной компетенции студентов посредством отдельных лингвосвязанных и культурно-связанных дисциплин остается недостаточно изученным как утверждают исследования ученых.

Как утверждает В. В. Сафонова: «В современной ситуации языковая подготовка в системе высшего образования должна обеспечивать развитие у обучающихся способностей, позволяющих использовать иностранный язык как инструмент общения в диалоге культур и цивилизаций современного мира.»

Эти способности могут быть развиты только на основе интеграции коммуникативного, социокультурного и межкультурного развития обучающихся средством иностранного языка, которые должны позволять использовать его в 
качестве проводника индивидуального-личностного проникновения в культуру других народов, а также и в образовательных и профессиональных целях.

Заключение. Таким образом, иностранный язык является средством не только для общения с носителями данного языка, но и средством распознавания культуры носителей и средством межкультурной коммуникации. Сделав вывод, мы можем отметить актуальность и значимость формирования межкультурной компетенции. В настоящее время в мировом образовании при изучении иностранного языка приходится учитывать этнокультурные, национальные факторы, что ведет нас к вопросу о поликультурном образовании. На первый план в сегодняшний день ставится подготовка подрастающего поколения к адекватному восприятию культурного окружения и владению навыками поликультурного общения и основами межкультурной компетенции. Исходя из этого, интерпретация культурного наследия при изучении иностранного языка есть совокупность знаний, умений и навыков обучающегося в области межкультурной коммуникативной деятельности, а также таких способностей как мотивация и ценности, способствующих успешному освоению и культуры, и изучаемого языка.

\section{Литературы:}

1. Головлева Е. Л. «Основы межкультурной коммуникации» Феникс, 2008

2. Белозерова А. В., Локтионова Н. М. «Лингвокультурология как лингвистическая дисциплина» - 2013 - №1

3. Артемьева О. А., Макуува М. Н., Мильруд Р. П. «Методология организации профессиональной подготовки специалиста на основе межкультурной коммуникации.» Тамбов, 2005

4. Болдырев Н. Н. «Лингвистические основы коммуникативных методов обучения иностранным языкам» 1998 №3

5. Воробьев В. В. «Лингвокультурология. Теория и методы» М.1997

6. «Межкультурный аспект исследования преподавания иностранного языка. Контексты современности.» Сборник научных статей, 2000

7. http://www.science-education.ru/ru/article/view?id=7681

8. https://www.dissercat.com/content/formirovanie-mezhkulturnoi-kompetentsii-studentov-vprotsesse-interpretatsii-inoyazychnogo-k

\section{ХХ АСР СЮРРЕАЛИЗМ АДАБИЁТИ}

\section{Қиличева Гулрух Нарзуллаевна Самарқанд Давлат Чет Тиллар Институти ўқитувчиси E-mail: kilicheva@samdchti.uz}

Annotation: The content of this article is about the emergence of the concept of surrealism as a new direction in literature and the formation of this literary direction. The article emphasizes that the main purpose of surrealism is to penetrate deep into the human mind, to get acquainted with supernatural phenomena, and to create another reality that is completely different from what exists. The works of surrealists reflect the theme of artistic development - the spiritual life of heroes, balanced on the border with consciousness and insanity.
Key words: cyurrealism, man, hallucinations, unconscious thought, image, psychoanalysis methods, relativity

Сюрреализм тушунчаси дастлаб Францияда XX асрнинг биринчи ўн йилликларида пайдо бўлган эстетик харакат хисобланади. 1920 йилларда Францияда шаклланди кейинчалик Испания ва АҚШнинг рассомлик адабиёт ва кино саньатида сюрреализм ўзини ёрқин намоён қилди. Сюрреализмнинг асосий мақсади инсон онгига чуқур кириб бориш ғайритабиий ходисалар билан танишиш ва мавжуд бўлган нарсадан мутлақ фарқ қиладиган бошқа хақиқатни яратиш эди. 
У капиталистик тизим инқирозининг тимсолига айланди ва Биринчи ва Иккинчи Жахон Урушлари даврида машхурликка эришди.

Сюрреализм сўзи француз шоири Гийом Апполинер томонидан қўлланилган. У бу атамани биринчи марта 1918 йилда ёзган “Замонлар ва шоирлар рухи” номли мақоласида ишлатган. XX асрнинг 20- йиллари бошларида сюрреализм мафкурасини яратган француз ёзувчи ва шоири Андре Бретон хисобланади.У 1924 йилда ўзининг “Сюрреализмнинг намойиши “номли машхур асарини ёзди.Ёзувчи бу асарида сюрреализм мафкурасини бутун дунёга тарғиб қилади.Қуйида ушбу асардан парча келтирамиз:

Hayotga ishonish, uning tasodifiy ko'rinishlarida (men haqiqiy hayotni nazarda tutaman) shu darajaga yetishimiz mumkinki, oxir oqibatda biz bu ishonchni yo'qotamiz .O'zining taqdiridan norozilik kundan-kunga oshib borayotgan bu to'liq xayolparast odam, endi $u$ foydalanishga majbur bo'lgan narsalarni tomosha qilishda qiynalmoqda ,unga beparvolik va o'z kuchi bilan, deyarli har doim harakatlari bilan yuklangan, chunki u o'zini javobgar deb topdi yoki hech bo'lmaganda o'z omadini sinab ko'rishni o'z zimmasiga oldi.

Сюрреализмнинг ижодкорлари ўзларининг ижодий манбаларини онг тубида ,тушлардаги ,ғайритабиий холатларда ,ақлдан озганлик ,галлюцинацияларда қидиришган.Бунга мисол қилиб Андре Бретоннинг "Хушёрлик" Филипп Супонинг “Тирилиш" Поль Элюарнинг "Мухаббат поэззияси” асарларини кўрсатиб ўтишимиз мумкин.

Сюрреалист ёзувчилар рухларини онг кучидан озод қилишга харакат қилганлар ва бунинг учун улар турли усуллардан фойдаланишган.Масалан гипнозли транснинг сеанслари ёки уларни хар бири кўрган тушларини жамоавий мухокама қилишган.Матнларни ёзиш учун онгсиз фикрлар ва иборалардан фойдаланишган.Француз сюрреалист шоирлари Роберт Деснос ва Рене Кревел худди шу усуллардан фойдаланган холда ижод қилишган.

Сюрреалистик шеьрият аньанавий тушунишда эмас,балки бизнинг онгимизда тасвир ва рамзларда вужудга келадиган психоанализ усулларидан фойдаланган холда ёзилганлиги билан ажралиб турган.

Улардан энг машхурлари “Қувонч олови” Луи Арагон,” Ернинг нури”, “Сувнинг рухи” Андре Бретон,"Мотам тутиш учун мотам" Роберт Деснос,"Ўлмас ўлими","Оғриқ пойтахти" Поль Элюар,"Самовий тавба" Антонин Арто кабилардир.

Сюрреализм учун инсон ва тинчлик макон ва вакт нисбийдир. Улар чегараларни йўқотадилар.Эстетик нисбийлик назарияси илгари сурилади, хамма нарса бузилади, силжийди, тарқалади ва хеч нарса аниқ эмас.

Сюрреализм дунё ва унинг қадриятларининг нисбийлигини тасдиқлайди.Бахт ва бахтсизлик ,шахсият ва жамият ўртасида чегара йўқ деб хисоблайди. Сюрреализмнинг метафориклиги тасвирларни хақиқий, сирли рангли ва сирли равишда беқарор қилади.Бу қарашлар Поль Элюарнинг " Севги тушунтириши " шеьрида ўз ифодасини топган:

Ты единственная, и я слышу траву твоего смеха.

Сен ягонасан, ва мен кулишингнинг қахқахасини эшитаман.

Ты - это вершина, что влечет тебя,

Сен - бу ўзингга тортадиган чуцққисан,

И с высоты угроз смертельных

Ва уллим тахдидлари баланлигидан

На спутанных глобусах дождя долин

Чалкаш ер шарининг ёмғир водийсида

Под тяжелым светом, под небом земли

Кучли ёруғлик ва осмон остида

Ты порождаешь падение.

Сен кулай бошлайсан. 
Птице уже недостаточное прибежище

Куш аллақачон бошпанасиз

Ни лень, ни усталость.

Дангасалик хам, чарчоқ хам эмас.

Ушбу супер реалликда инсон ва дунёнинг хақиқий алоқаси йўқолиб чиройли ноаниқ ва сирли нарсага айланади. Сюрреалистларнинг асарларида бадиий ривожланиш мавзуси - онг ва ақлсизлик билан чегарада мувозанатлашган қахрамонларнинг рухий хаёти акс эттирилади.

Сюрреализм, биринчи навбатда, адабий харакат сифатида пайдо бўлди.

1920 йилда француз ёзувчилари Филипп Супо ва Андре Бретон томонидан сюрреалистик ғоялар билан сингдирилган “Магнит майдонлари” асари яратилди. Ушбу муаллифлар юқорида таькидлаб ўтганимиздек адабиётда сюрреализмнинг асосчилари хисобланишади. Умуман олганда, бу йўналишда Поль Элюар, Роберт Деснос, Антонин Арто ,Рене Шар, Жак Превер каби шоир ва драматурглар ижод қилишди. Шундай қилиб сюрреализмнинг таьсири кейинчалик Лотин Америкаси шоирларининг асарларида, 1970 йилларда АҚШ ва славян мамлакатларининг адабий йўналишида ўз аксини топди.Сюрреалистлар томондан ишлаб чиқилган услублар XX аср адабиёти ва саньатига таьсир кўрсатган деб айтишимиз мумкин.

\section{Адабиётлар:}

1. Антология французского сюрреализма. 20-е годы / Сост., комм. и пер. С. Исаева и Е. Гальцовой. - М.: ГИТИС 1994.

2. Гальцова Е. Д. Творчество Андре Бретона как энциклопедия сюрреализма. - М.: ИМЛИ РАН, 2019

3. Сюрреализм. Воззвания и трактаты международного движения с 1920-х годов до наших дней / Сост. и предисл. Ги Жирара; пер. под ред. С. Дубина. М.: Гилея, 2018

4. Пинковский В. И. Поэзия французского сюрреализма: проблема жанра. - Магадан: Кордис, 2007

\section{ANALYSIS OF CONCEPTUAL METAPHORS WITH MENTALITY ELEMENTS IN ENGLISH COMPARED TO UZBEK EQUIVALENTS}

\section{Masharipov Jahongir Axmedovich \\ Urganch Davlat Universiteti o'qituvchisi \\ j.masharipov.4264688@gmail.com \\ Abdullayev Doniyor Bahodirovich \\ Xiva tuman 14-son maktab o'qituvchisi uzb080@gmail.com \\ Hayitboyeva Oltinoy Shonazar qizi \\ Urganch Davlat Universiteti talabasi \\ hayitboyevaoltinoy@gmail.com}

Annotation: The article illustrates the concept of conceptual metaphor those with mentality elements. A few instances are presented from a literary book and compared with their Uzbek analogues.
Key words :

Metaphor, conceptual metaphor, cognition, mentality, mentality component.

Metaphor has been studied widely so far. Regarding conceptual metaphors, they are investigated by few. Metaphor, from traditional point of view, is considered as stylistic device and is subject matter of stylistics and lexicology. Conceptual metaphor, on the other hand, is much wider concept than the former. Although the mutual formula is ' $A$ is $B$ ' $[1,65]$, conceptual metaphor is something connected with cognition and the subject matter of 
cognitive linguistics. In this article, we try to illustrate some prevalent conceptual metaphors found in English and Uzbek. We try to compare them whenever possible, discuss their equivalents (if one exists) and illustrate with examples.

Now look at this example:

Shut your lousy trap. These here kids is got nerve $[3,128]$

This is a pretty bright example of mentality, as it is uttered by a tree seller. He is an illiterate, rude man but with kind heart. In his mind he can be polite and loveable, but considering his business he has become such a man. The reasons for the usage of these metaphors are that firstly, the life has affected him to be so, secondly he cares a lot about business (He sells fir-trees, if there are ones left unsold he gives them for free on condition that if the demander is able to stand at the throwing of a fir-tree) and as result he is so crude. We can get conceptual metaphors like MOUTH IS TRAP, MOUTH IS HAIRY, COURAGE IS NERVE. [2, 74] When we think Uzbek equivalents of those sentences, we cannot get the same metaphors. Word-for-word translation would be - Bitlagan qopqoningni yop. Bu yerdagi bolalarning ham asabi bor. As you can see, in Uzbek it does not make sense. With the second example, we may use the word 'asab' with meaning 'jasurlik, mardlik', yet with og'iz we have not come across a similar metaphor. Perhaps, in Uzbek metaphor may be omitted here.

TREES ARE HUMAN

This cognition is also widespread among different languages, so in our languages too. During prehistoric times, trees are thought to be alive and have senses. Several metaphorical expressions are used like bearded with moss, in garments green, tree knew, that was the kind tree it was, it liked poor people, its umbrellas curled over. From these examples it is apparent that the features of human are directly passed to trees. Conceptual metaphor TREES ARE HUMAN in the English language can correspond to Uzbek, whereas not all metaphorical expressions can have the same meaning in the Uzbek language. For instance, examples like in garments green (yashil libosda), tree knew (daraxt bilardi), it liked poor people (u kambag'al odamlarni yaxshi ko'rardi), kind tree (mehribon daraxt) are similar to the Uzbek versions, however bearded with moss cannot have appropriate equivalent, word for word translation is maysadan soqol qo'ygan, this metaphorical expression doesn't have equivalent in Uzbek. More examples in English

Come, little leaves, said the wind one day

Come o'er the meadows with me and play

Put on your dresses of red and gold...

There is a conceptual metaphor THE FOUR ELEMENTS OF LIFE ARE HUMANS.

This conceptual metaphor is widespread worldwide. Mentality element affecting here traces back to prehistoric times. It goes without saying that this assumption is absolute true. However, according to the literature and myths and mostly religious sources, we can claim that this contention makes a sense. In those times, people tried to understand their surroundings, the nature and even themselves. Therefore, if there was something that beyond their cognition they began considering them as mighty. The most commonplace and prevalent forces were undoubtedly earth, water, wind and fire. This cognition spread worldwide we think. As a proof for this contention we can say certain ceremonies, like, when a child comes to the world, it is washed by water, when a person dies, he or she buried to earth, or being cremated, in some places the ashes (of cremated person) are thrown into water or blown away by wind, and etc. as you see they can differ by elements, yet one of them is present especially when there is birth or death, or some other essential event in one's life.

Other examples:

When the sweet wind did gently kiss the trees

And they did make no noise 
Yulduzlar sirli ko'z qisishar, tillaqoshdek ingichka oy sirli mo'ralar, shabada shivirlar... ${ }^{1}$ ONE PERSON IS ANY KIND OF PERSON FROM THE SAME NATIONALITY OR HAVING PARTICULAR QUALITY

Each one thinks that she might be making the real little Jesus - referring to prophet

It will be just another Mick - referring to ordinary person

Often we compare people within a society, that is to say one person to another. Thus, the characteristics of the former are passed onto another. This phenomenon is also noticed in several languages, including English and Uzbek. Usually the best, the most admired, the strongest, the wisest and likewise people or the least privileged such as the laziest, the dullest, the weakest are compared to other people. In the first metaphorical expression little Jesus the mentality of religion is affecting, as in the Uzbek language the impact of Islam is strong and it would be Muhammad to be compared. This is a nice example of transferring the prophecy features to someone by not saying directly. There is mentality to abstain calling himself directly a prophet. In the Uzbek language, this expression is not often used though.

In the second example, Mick refers to any ordinary Irishman. Uzbek equivalent would be AFANDI (local, i.e. Khoresmian version would be Qummi or Jummi*). Here the mentality is about deeds of one person. They can be called as stereotypes. Once one person (no matter where lives, Britain or Uzbekistan) did something awkward, extraordinary or hilarious, and his name or title passes to whole nation. There is an impact of nationality.

HUMANS ARE SUPREME BEINGS

From the prehistoric times human beings compared themselves to supreme beings like

God, the Devil, angels, prophets and others due to some peculiarities or because of their attributes. This conceptual metaphor can be considered as virtually universal, since in many languages one can meet the same equivalent of the following example:

English Uzbek Russian

Yes he is the Devil Ha, u iblis Да, онДьявол

The mentality component here is religion, as in all religions Satan is considered to be evil and vicious. $[2,80]$ There are a plethora of other examples like this. We attempted to present the ones that are commonplace. As you can see, this is an intriguing topic to investigate and we try to discover further instances of conceptual metaphors with mentality components.

\section{Adabiyotlar:}

1. Ermetova J. Manual on the English stylistics. Urgench, 2007

2. Masharipov J. Conceptual analysis of the components of metaphor with the elements of mentality in English and Uzbek and their lexico-stylistic features. Dissertation. Urgench. 2018.p74-80

3. Smith B. A tree grows in Brooklyn. Harper\&Row, Publishers, New York,1947, p128

\section{ПРИНЦИПЫ ФОРМИРОВАНИЯ И ИНТЕРПРЕТАЦИИ КОНЦЕПТУАЛЬНОЙ МЕТАФОРЫ}

Музафарова Луиза Умаровна ст. преподаватель СамГИИЯ E-mail:Lluizamuzafarowa@yandex.com

Annotation: Metaphor is a key phenomenon in cognitive linguistics and the study of the principles of its formation and interpretation is an urgent task. In this article, the process of forming a metaphorical expression is analyzed within the framework of the theory of conceptual integration.
Key words : metaphor, mental spaces, conceptual integration, conceptual blending 
Знания, которые мы обретаем, в нашем случае посредством языка, имеют свойство не только накапливаться, т.е. меняться количественно. Мышление человека способно порождать новые значения, что приводит к качественным изменениям в структуре сознания. Отметим, что авторитетные лингвисты-когнитологи Ж.Фоконье и М.Тернер предполагают, что именно способность к инновации и созданию новых значений, которая опирается на воображение и абстрактное мышление, позволило человеку совершить качественный рывок в развитии в эпоху верхнего палеолита и выделиться из общей массы млекопитающих [1, v].

Сознание человека обладает способностью к продуцированию нового содержания с опорой на известное, уже присутствующее в памяти, а также посредством сведѐния вместе различных феноменов, при наличии у них общих черт. Наиболее наглядно этот сложный речемыслительный процесс может быть представлен на примере метафоры, занимающей чрезвычайно важное место в когнитологии вообще, и в когнитивной лингвистике в частности.

Метафора, как проявление аналоговых возможностей человеческого сознания и мышления, занимает ключевое положение в когнитивных процессах. В современной когнитивной науке метафора считается ключевой ментальной операцией, способом познания, категоризации оценки и объяснения мира. Метафора является не только фигурой речи, средством выражения мысли, но и самим средством мышления и познания, что подчеркивается в названии классического исследования Дж.Лакоффа и М.Джонсона "Метафоры, которыми мы живем" ("MetaphorsWeLiveby") [2], в котором сформулированы ключевые положения когнитивной теории метафоры. Современные исследователи, в частности А.Чудинов и Э.Будаев, отмечают, что метафоры помогают нам преобразовывать существующую в сознании адресата языковую картину мира, ввести новую категоризацию и представление, казалось бы хорошо известных феноменов, и подчеркивают значимость эстетического потенциала метафоры и ее способность представлять эмоциональную оценку действительности [3, 54].

С того момента, как теория метафоры была сформулирована, она постоянно дорабатывалась и расширялась, в том числе и применительно к другим отраслям науки. В обобщенном виде, в соответствии с теорией метафоры, основу метафоризации составляет процесс взаимодействия между двумя, как минимум, структурами знания (доменами), одна из которых становится источником (sourcedomain), a другая мишенью (targetdomain). Опыт взаимодействия человека с окружающим миром формирует одностороннюю метафорическую проекцию (metaphoricalmapping) элементов сферы источника на сферу-мишень, при этом элементы последней определенным образом структурируются, и таким образом формируется когнитивный концептуальный потенциал метафоры. Существенным представляется то, что базовым источником знания, лежащего в основе концептуальных доменов, является опыт непосредственного, изначально физического, взаимодействия человека с окружающим миром. Этот опыт позволяет осуществить категоризацию действительности в виде когнитивных структур, т.н. "схем образов". Метафорическая проекция затрагивает не только составляющие элементы, но и полностью структуры концептуальных сфер (домены).

В рамках развития и углубления теории метафоры, некоторые исследователи, в частности Дж.Лакофф и М.Тернер [4; 5], выдвинули предположение, согласно которому при метафорической проекции в сфере-мишени сохраняется, пусть и частично, структура сферы-источника. Этот тезис получил название гипотезы инвариантности (InvarianceHypothesis). Существование данного инварианта становится основанием для метафорических следствий (metaphoricalentailments), которые зачастую не имеют эксплицитного воплощения в метафорическом выражении, но выявляются на основе 
знания о фрейме. Как следствие, глубокий анализ фрейма сферы-источника является залогом адекватного осмысления сферы-мишени.

Когнитивный подход к изучению метафоры, судя по числу и разнообразию аспектов изучения, представляет собой активно развивающееся и перспективное направление в современной когнитивной лингвистике. Концептуальные метафоры охватывают практически всю сферу человеческой деятельности и опыта и, как следствие, наделены значимым когнитивным потенциалом, что подтверждается многочисленными исследованиями концептуальной метафоры.

Продуктивным оказывается рассмотрение концептуальной метафоры в рамках теории концептуальной интеграции, основные положения которой были разработаны Ж. Фоконье и М. Тернером, и изложены в книге "TheWayWeThink" [1]. Данная теория сама является творческим развитием идей, сформулированных Ж.Фоконье, и известных как теория ментальных пространств [6]. Исследователь полагает, ментальные пространства создаются участником коммуникации как вспомогательные средства, которые помогают коммуниканту понимать высказывания других и порождать собственные. Для их описания Ж.Фоконье вводит понятие исходного пространства (parentspace) и набора "порождающих операторов" (spacebuilders), лингвистических выражений, которые маркируют появление нового ментального пространства на основе исходного. При этом, с помощью специальных «коннекторов» (connectors) устанавливается соответствие между элементами исходного пространства и их аналогами в возникающих пространствах [7].

В основе теории концептуальной интеграции лежат утверждение о том, что способность создавать новые смыслы, в том числе и в языке, на уже существующих присуща исключительно человеку, а формой реализации данной способности является порождение интегрального ментального пространства (blendingspace), или бленда, несущего новые смыслы на основе базовых ментальных пространств (inputspaces). По мнению авторов теории, процесс концептуальной интеграции является определяющим для широкого спектра лингвистических явлений, в первую очередь, таких как метонимия и метафора [1].

Очевидно, что изучение принципов и механизмов формирования и последующей интерпретации концептуальной метафоры, особенно в пространстве художественного текста, наделено значительным потенциалом исследования и перспективой дальнейшего развития.

\section{Литературы:}

1. Глебкин В.В. Теория концептуальной интеграции Ж.Фоконье и М.Тернера: опыт системного анализа // Вопросы философии (электронная версия). Дата публикации 11.10.2013 г. Режим http://vphil.ru/index.php?id=826\&option=com content\&task=view

2. Чудинов А.П., Будаев Э.В. Когнитивная теория метафоры на современном этапе развития // Вопросы когнитивной лингвистики. 2007. №4. - С. 54-57.

3. Fauconnier G. Mental Spaces: Aspects of Meaning Construction in Natural Language. Cambridge University Press, 2003.

4. Fauconnier G., Turner M. The Way We Think. Conceptual Blending and the Mind's Hidden Complexities. N. Y., 2002

5. Lakoff G.The Invariance Hypothesis: Is Abstract Reason Based on Image Schemata? // Cognitive Linguistics. 1990. Vol. 1(1).

6. Lakoff G., Johnson M. Metaphors We Live by. Chicago, 1980.

7. Turner M. Aspects of the Invariance Hypothesis // Cognitive Linguistics. 1990.Vol. 1(2). 


\section{ЧЕХ ОЛИМИ ИРЖИЙ ЛЕВЫЙНИНГ ТАРЖИМА НАЗАРИЯСИГА ОИД ҚАРАШЛАРИ}

\section{Мухамедов Азизбек Холмурат ўғли Жиззах давлат педагигика институти катта ўқитувчиси \\ E-mail: azizbek-uzb@mail.ru}

Annotation: In the research author explores scholastic concepts of Czech literary historian and translation theoretician Jiří Levý who made original and valuable contributions to the development of translation theory in Europe and his theoretical views on machine and literary translation.
Key words : Jiří Levý, theory of translation, The Art of Translation, machine translation, literary translation.

Иржий Левый ўз фаолиятини 50-йиллар охирида бошлаган бўлсада, олимнинг энг мухим фикрлари унинг “Таржима санъати” [1] номли машхур китобида ўз ифодасини топган эди. У 1958 йил “Таржима назариясининг асосий масалалари” [2] мавзусида диссертация ёқлагач уни 1963 йил немис тилида китоб шаклида нашр эттиради [3]. 1969 йил китобнинг қайта ишланган нашри немис тилида ва тўлдирилган нашри 1974 йил рус тилида нашр қилинади. У чех, немис ва рус тилларини пухта билган олим эди.

Иржий Левый тадқиқ этишнинг семиотика ва ахборот назариясига асосланган янги усуллари тараққиётини диққат билан кузатиб борган хамда уларга юксак бахо берган, аммо ўзи бу усуллардан жуда эхтиёткорлик билан фойдаланган. У ўз китоби хақида бундай ёзади: “Ушбу китобнинг методи, асосан, структуралистикдир. Математик лингвистиканинг янги усулларидан эса таржиманинг амалий масалаларини улар ёрдамида аниқроқ ёритиш мумкин бўлган ўринлардагина фойдаланилди" [3,40].

Бизнингча, бунда хеч қандай тасодифнинг ўзи йўқ. Чунки янги лингвистик усулларга тобора чуқурроқ кириб бориш, ўз галида, таржиманинг умумий назарияси масаласини хам келтириб чиқарарди. Аммо Иржий Левый шу масала атрофида юзага келган бахс-мунозараларга тўғридан-тўғри қўшилмади ва ўз тадқиқот объектини “эмпирик” деб белгилаб "хар хил турдаги кўплаб матнлар" орасидан у, аввало, “адабиётнинг уч асосий жанри: бадиий наср, шеърият ва драматургияни” [3,34] танлаб олади. Шу тариқа китобда муаллифлар таржима муаммоларини бадиий таржима аспектида кўриб чиқади.

И.И. Резвин мазкур тадқиқот хақида сўз юритиб, И.Левый китобининг "ахборот назарияси атамаларини қўллашга интилган” сахифалари унчалик муваффақиятли чиқмаган, аксинча, “таржимани адабиёт назарияси, поэтика ва эстетика атамалари воситасида батафсил ва изчил ёритган” сахифалари асар фазилатини белгилаган, деган эди $[4,428]$.

Иржий Левый ўз қарашларини ўша даврда илгари сурилган бир неча концепцияга муносабатда ривожлантирди. Олим ўша кезлар юзага келган назарий тадқиқотлар, шу мамлакатда кечган бахс-мунозаралардан хам яхши хабардор бўлган. Масалан, у машина таржимаси мавзусига хам эътибор қаратиб, И.Ревзин ва В.Розенцвейг “Основы общего и машинного перевода (1964)" номли китобидаги баъзи хулосаларга эътироз билдиради. Иржий Левый машина таржимаси муаммоларини бадиий таржима муаммолари билан биргаликда текширишга кескин қарши чиқади: "Машина таржимасининг амалий мақсад ва усуллари хозирда кўп жихатдан бадиий таржиманинг амалий мақсад ва усулларига қарама-қарши туради. Машина таржимасига мослаб лексик жадваллар тузишда, аслият тилидаги битта сўзга таржима 
тилида хам битта сўз мувофиқ келиши учун сўзнинг семантик майдонини торайтиришга интилиш бўлиши табиийдир. Бадиий таржимада эса, аксинча, оддий луғавий эквивалентдан халос бўлиш ва синоним сўзлар гурухи билан иш кўришга интилиш хукмронлик қилади. Машина таржимасида жумлани иложи борича соддароқ бирликларга ажратиш тақозо этилади. Бадиий таржимада эса, аксинча, энг юқори бирликни ифодалаш мухимдир. Машина таржимаси сўзнинг гапдан ташқаридаги маъно ва сўзлар билан алоқасини истисно қилади. Янаям мухими, талқин эта олмайди ва бунга даъво хам қилмайди. Шунинг учун машина таржимасида ахборотнинг бир қисми бой берилади ва ахборотга хеч қачон янги маъно қўшилмайди" " $[3,29]$.

Бу фикрларнинг айримлари хозир мубхам бўлиб кўриниши мумкин. Хозир деганда шу назарда тутилмоқдаки, машина таржимаси такомиллашгани сари у бадиий таржимага яқинлашиб бориши мумкин. Машина таржимасида "ахборотга хеч қачон янги маъно қўшилмайди” деган фикрни тўғри деб қабул қилиш мушкул. Чунки табиий тиллар ўртасидаги фарқ-тафовутлар янги маъно нозикликлари юзага келишини муқаррар равишда заруратга айлантиради. Бу таржима қилинаётган матндан келиб чиқмайди, балки янги тилда сўзлар бир-бири билан боғланишидан келиб чиқади. Демак, бу ўринда машинанинг “объективлиги” энг мақбул ечимни топишга қодир эмас, фақат тирик таржимоннинг “субъективлиги” шундай ечимни топишга қодирдир. Аммо бу фикрлар қоғозга тушган даврда бадиий таржиманинг талқин этувчилик табиатини асослаш долзарб хисобланарди. Бу эса, ўз галида, китобга теран сингдирилган функционал ёндашув, “ўз” ўқувчисига қараб мўлжал олиш истаги билан алоқадордир: "Таржима назарияси учун нисбатан ижодий деб функционал ўхшашлик концепциясини хисоблаш мумкин”, дея ёзади И.Левый " [3,36]. Шу сабаб ўзи кенг қўллаган “матн” тушунчаси олимда алохида хурмат-эхтиром хиссини уйғотмайди ва айни тушунча унинг кўзидан на аслият, на таржиманинг хаётий контекстини тўсиб қўёлмайди. Бу хақда у шундай ёзади: “Таржимон учун бошланғич материал - аслият матни эмас, шу матнга жойланган ахборотдир, унинг мақсади хам таржима матни эмас, шу матнни ўқувчига етказадиган ахборотдир" [3,58].

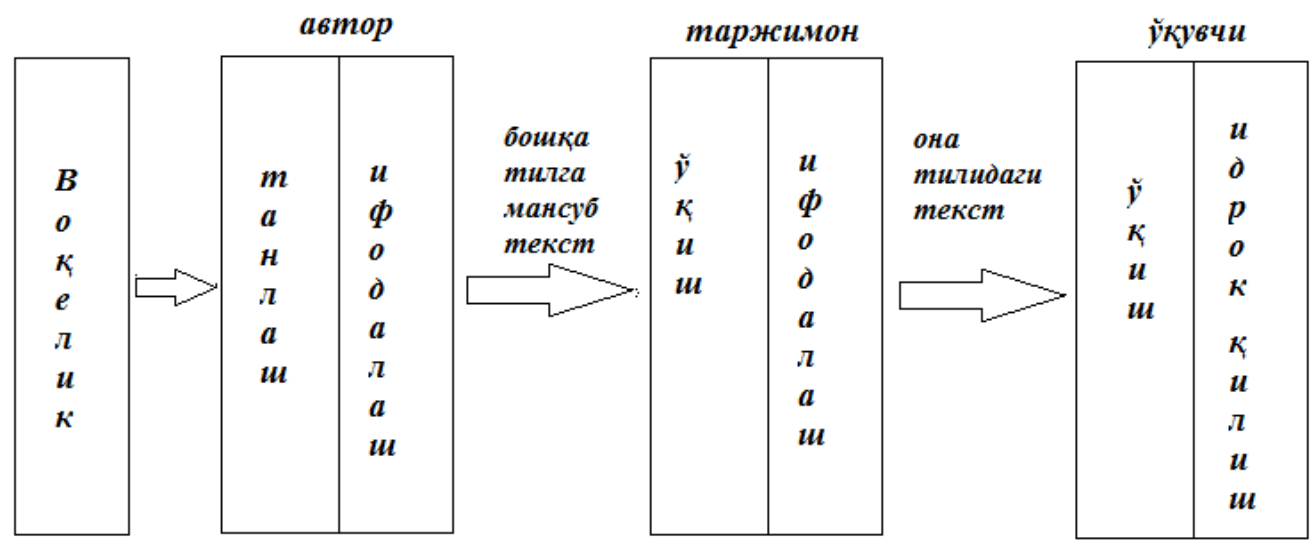

Муаллиф келтирган ушбу схема ўша давр бахс-мунозараларини тушунишга ёрдамлашади. Ундаги икки жихат, айниқса, киши диққатини тортади. Биринчидан, бу жараённинг барча субъектлари (муаллиф, таржимон, ўқувчи) иштироки иккиёқлама тасаввур этилган бўлиб, булар - идрок (ёзувчида “саралаш", таржимон ва ўқувчида эса “ўқиш”) хамда фаолият (ёзувчи ва таржимонда “ифода”, яъни ижодий жараён, ўкувчида эса “конкретлаштириш”, яъни ўқилганни фаол идрок этиш)дир. Иккинчидан, унда тиллараро мулоқот жараёнининг асосий иштирокчилари - муаллиф ва таржимондан ташқари яна икки мухим якуний халқа - мутаржимлик фаолиятининг мақсад-муддаоси сифатида ўқувчи, шунингдек, адабий мулоқотнинг бошланғич нуқтаси сифатида воқелик хам назарда тутилади. 
Ушбу схемада акс этмаган “таржимон” ва “воқелик” муносабати хақида Иржий Левый ёзади: “Санъаткор-мутаржим билан косиб-таржимон ўртасидаги асосий фарқ шундаки, улардан дастлабкиси аслият билан таржима оралиғида муаллиф қаламга олган воқелик манзараларини ўз хаёлотида жонлантирса, яъни матн замиридаги характерлар, шароитлар, ғояларга теран кириб борса, иккинчиси эса атиги матнни идрок этади ва фақат сўзни таржима қилади. Бундан эса таржимоннинг бадиий идрокига нисбатан шундай талаб юзага чиқади: соддагина “аслият матни - таржима матни” жараёнини бундан анча мураккаб, аммо мутлақо тўлақонли “аслият матни тасаввурий воқелик - таржима матни” жараёни билан алмаштирмоқ лозим. Таржимон, албатта, содда, қисқа жараёнга кўпроқ мойиллик билдиради, чунки унга шуниси қулай: воқеликни қайта яратиш эса хаёлотни ва матннинг чуқур талқинини тақозо этади" " $[3,63]$.

Собиқ иттифоқ олимлари яратган “реалистик таржима” концепциясини қабул этган ва И.А. Кашкин фикрларини маъқуллаган холда унинг изидан бориб “таржиманинг хаққонийлиги” тушунчасини қўллаган, айрим вазиятларда эса хатто И.А. Кашкиннинг исбот-далилларини такрорлаган (гарчи совет матбуотида "реалистик таржима" ибораси баъзан “яхши таржима" иборасининг синоними сифатида қўлланиши, бу эса иборани “аниқ маъноси”дан махрум этишини таъкидласа-да), И.Левый, барибир, таржиманинг “иллюзионистик” усули афзалроқ деган хулосага келади" $[3,43]$.

Иржий Левый фикрича, таржимага ёндашувнинг бутун тарихини (таржима усулларининг ўзини хам) иккига: китобхонда у оригинал асарни ўқиётгандек иллюзия хосил қилишни ўз олдига мақсад этиб қўювчи “иллюзионистик” хамда китобхонга айнан таржима, яъни “ёт-бегона" бир нарсани тақдим этаётганини яширмовчи “аксил иллиюзионистик” турларга ажратиш мумкин. У, ўз салафларидан фарқли ўлароқ, ўқувчи рецепцияси (идроки) тушунчасини анча аниқ қилиб истеъмолга киритди. Бу хақда И. Левый шундай ёзади: “Аслият ва таржима ўртасидаги муносабат - асар ва унинг бошқа материалдаги ижроси ўртасидаги муносабатдир. Бунда аслиятни мазмун ва шакл яхлитлиги ўлароқ бошқа материалда гавдалантириш эмас, балки шу яхлитликни рещепиент онгида конкретлаштириш ёхуд содда қилиб айтилса, якуний таассурот, ўқувчини тўлқинлантириш бирламчи хисобланади"1.

Таржиманинг диалектик ходисалигини англаш И.Левый концепциясининг асосий фазилатларидан хисобланади. Қисм ва бутун, мазмун ва шакл ўртасидаги қарамақаршиликни, аслият билан таржиманинг маданий анъана, тарихий давр, миллий адабиёт ва жахон сўз санъати доирасидаги функциялариаро мураккаб алоқаларни кўрсатиб бериши Иржий Левый концепциясига мукаммаллик бахш этди, бадиий қайта яратиш ва бадиий идрок этишнинг формаллашган семиотик-лингвистик усуллар назаридан четда қолувчи нозикликларини хам тадқиқ этишга имкон яратди. Айни фазилатлар Иржий Левый асарининг умрзоқлиги ва мазкур олимнинг хозирги бахсмунозаралардаги нуфузини белгилаб бераётир.

\section{Адабиётлар:}

1. Левый И. Основные теории перевода. Прага, 1958.

2. LevyJ. Umění překladu. Прага, 1963; DieliterarischeÜbersetzung. Theorie e. Kunstgattung. Frankfurt a.M., Bonn, Athenäum-Verl, 1969.

3. Левый И. Искусство перевода. - М., 1974.

4. Мастерство перевода. - М.: Советский писатель, 1969. С. 428 


\section{ЎЗБЕК ТАРЖИМА НАЗАРИЯСИНИНГ ТАРАҚҚИЁТ ПРИНЦИПЛАРИ (ПРОФЕССОР Ғ.САЛОМОВ ВА Қ. МУСАЕВ МИСОЛИДА)}

\section{Мухамедов Азизбек Холмурат ўғли Жиззах давлат педагигика институти катта ўқитувчиси E-mail:azizbek-uzb@mail.ru}

Annotation: The present article discusses traditions and principles of development of Uzbek translation theory in the 1980s. Translation concepts and works created by such famous scholars as Gaybulla Salomov, Kudrat Musaev and others are the main purpose of the research.
Key words : theory of translation, linguistic approach, literary approach, translation techniques.

1980-йилларнинг охирига келиб таржима назариясининг тилшунослик йўналиши тамойиллари янада такомиллашди. Таржиманинг адабиётшунослик йўналишига мансуб И.Кашкин ва Г.Гачечиладзенинг "реалистик таржима назарияси" ўрнини Д.Дюришиннинг “таржима халқаро адабий жараён тараққиётида мухим ўрин эгалловчи адабиётлараро коммуникатив воситадир” [1] дегувчи назарияси эгаллади. Айнан бу йилларда Д.Дюришин ТошДУ (ЎзМУ)нинг Таржима назарияси кафедрасида қатор маърузалар ўқиди. Ўша пайтларда кафедра мудири бўлган проф. Ғайбулла Саломов ва шогирдлари Д.Дюришин назарияси ортидан бориб илмий тадқиқотлар яратдилар.

1982 йил профессор Ғайбулла Саломов хам “Адабий анъаналар ва бадиий таржима муаммолари" [2] мавзусида докторлик диссертациясини химоя қилгунига қадар Ўзбекистонда таржимашунослик илми тараққиётига катта хисса қушшган “Тил ва таржима” (1966), “Таржима назариясига кириш” (1978), “Адабий анъана ва бадиий таржима” (1980), “Дўстлик кўприклари” (Н.Комилов билан хамкорликда) (1979) каби қатор монография ва дарсликлар яратди, “Таржима тарихи”, “Таржима назарияси” ва “Таржима танқиди” (1973) фанларидан ўқув дастурларини тузди.

Профессор Ғ. Саломов 1980 йил ўзининг “Адабий анъана ва бадиий таржима" монографиясини нашр эттирди [3, 159]. Ушбу монография олимнинг докторлик диссертацияси мазмунинг асосий назарияси тезисларини ўзида жамлаган эди. Ғайбулла Саломов чех олими Диониз Дрюшиннинг таржима назарияси умумфилологик фан бўлиб у адабиётлар муштараклиги ва хамкорлигига хизмат қилиши зарур, мазмунидаги фикрларига эргашар экан “бир асарнинг бир неча таржимаси бўлиши зарурати, таржимада давр рухини акс эттириш хамда, адабий анъананинг давомийлиги ва таржима савиясига таъсири ўрганилган" [4,24].

Профессор Ғ.Саломов ўз диссертациясида Шарқ ва Ғарб адабиётларидан ўгирилган таржималарни ўзаро адабий алоқалар ва ўзаро таъсир доирасида тадқиқ қилган. Шунингдек таржимада услуб ва услубий мослашув ўзбек таржимонларининг ижодий методи такомилида орттирилган бой тажрибалар заминида ёритиб берилган. Олимнинг докторлик диссертациясини "Анъана ва хозирги адабий жараён"; "Ўзбек адабиётида Шекспир анъаналари”; “Таржима-таъсир-таржима”; "Бадиий таржимада услуб"; "Миллий услубий ўзига хослик ва бадиий таржимада услублаштириш принциплари"; "Шеърий таржимада ритмик трансформация"; “Ижодий белингвизм анъаналари” каби қатор муаммоларнинг ечимини топишга уринган. Ишда олим узоқ йиллар олиб борган кузатишларини ечимини топишга эришган ва нихоят таржима назарияси мустақил умум филологик фан дегувчи якуний хулосага келган [5]. 
Профессор Ғ. Саломов 1983 йил ўзининг “Таржима ташвишлари” номли монографиясини эълон қилди. Унда олим таржима техникаси ва таржима назарияси санъати билан боғлиқ масалаларни тадқиқ қилиб, таржимага эхтиёж туғдирувчи асосий омиллар, пировард натижада эришилган хосила, яъни муайян таржима туфайли ватан адабиётида пайдо бўлган сифат ўзгаришлари хусусида хам ўз фикрмулохазаларини билдирган.

Профессор Ғ. Саломовнинг сўнгги китоби “Таржима назарияси ва амалиётидан маърузалар матни" мустақиллик йилларида чоп этилди. Унда муаллиф “Муаззам истиқлол даврининг таржималари шу улуғвор даврнинг мақсади, талаби ва вазифаларига мос ва муносиб бўлиши лозим" деб ёзган эди. Бу йилларда проф. Ғ.Саломов шогирдлари М.Бақоева, Ғ. Хўжаев, Қ. Тожиев, С.Хайитов, С.Азимовлар номзодлик диссертацияларини химоя қилишади. Шунингдек, Г.Ғафурова [6,38], Н.Комилов [7,42], Қ.Мусаевлар $[8,38]$ докторлик диссертацияларини химоя қилдилар.

Гарчи Гулнора Ғафурова ўтган давр ичида ўзбек тилидан рус тилига қилинган таржималар мисолида таржима асараларининг адабиётлар хамкордигида тутган ўрнини тахлил қилиб берган бўлса, Нажмиддин Комилов XIX асрда Хоразм таржима мактаби мисолида ўзбек таржима тарихини ёритиб берди. Қудрат Мусаев ғарбий европа, хусусан инглиз ва рус адабиётидан ўгирилган таржималар мисолида таржима назариясининг стилистик муаммоларини бартараф этишнинг назарий принципларини биринчи бўлиб ишлаб чиқди.

Қ.Мусаев докторлик диссертацияси асосида 2005 йил ўзининг “Таржима назарияси асослари" номли монографиясини нашр эттирди. Рус ва инглиз адабиётидан ўзбек тилига таржима муаммоларини кенг қамраб ўрганишни мақсад қилиб қўйган “ушбу китоб таржима назарияси ва танқидчилигида хали деярли қўл урилмаган, шу билан бирга хаётий зарур, таржимонлик фаолияти тахлилининг мундарижасини ташкил этадиган масалаларни ўз ичига қамраб олган" [9,352].

Олим ишнинг биринчи “Ижодий таржима ва илмий тахлил” номли бобида билвосита ва бевосита таржима афзалликлари ва нуқсонлари тўғрисида тўхталаркан, асосан қуйида хулосага қелади: “Бевосита таржима масалалари илмий муаммо сифатида олимлар томонидан хал қилинаётган экан бу, албатта, бажарилажак таржималар сифатининг борган сари яхшиланишига замин тайёрлайди. Бу хил таржимани билвосита таржимага қарши қўйган холда, уни узлуксиз ташвиқот қила бориш зарур." [9,46]. Фикрини давом эттириб, муаллиф якуний хулосага келади: "Аслида масалага бутунлай бошқача ёндашиш зарур. Ягона ижобий усул сифатида, бевосита таржимани қаттиқ туриб химоя қилган, уни ташвиқ ва тарғиб этган хамда назарий умумлаштирган холда, воситачи тил орқали таржимага хорижий тиллардан таржима қиладиган малакали таржимонларнинг кўплаб пайдо бўла бориши оқибатида аста-секинлик билан йўқ бўлиб кетаверадиган, сақлаб қолинишига эса хеч қандай эхтиёж туғилмайдиган сохта усул сифатида қаралиши лозим" [9,47].

Профессор Қудрат Мусаев аслида инглиз, рус ва форс-тожик тилларини мукаммал эгаллаган таржимашунос олим сифатида билдирган юқоридаги фикрлари ўтган асрда хам, XXI асрнинг бугунида хам долзарб бўлиб турибди. Сабаби, республикамизда хорижий тилларни мукаммал эгаллаган таржимонлар плеядаси етишиб келмоқда. Бевосита таржима амалиёти сохасида Янглиш Эгамова, Абдулла Шер, Мирзали Акбаров, Амир Файзилла, Абдимурод Кўчибоев, Динора Султонова, Бегойим Холбекова, Шоазим Минавваров сингари мохир таржимонлар етишиб чиқди. Бироқ билвосита таржима усталари Қодир Мирхамедов, Иброхим Ғафуров, Ахмад Аъзам, Мирпулат Мирзо кабилар бажарган таржималар ўқимишлилиги билан таржима амалиётида устунлик қилиб келмоқда. 
Демак, бизнингча хам таржима амалиётида хар иккала услуб - билвосита ва бевосита таржимани қўллаш давом этаверади, улар ўзаро рақобатта бир-бирини тўлдириб боради деган фикрдамиз.

Профессор Қудрат Мусаев китобнинг иккинчи “Таржима тахлилининг назарий асосларини" номли бобида ғарб ва рус таржимашунослари Р.Якобсон, Ю.Найда, Ж.Кэтфорд, И.Левый, А.В. Федоров, А.В. Кунин, В.Н. Комиссаров каби назариётчилар изидан бориб “Таржима-тилшуносликнинг тадқиқот объекти” эканлиги, “Таржимавий эквивалентлик”, “Прагматик таржима” принциплари бўйича ўзбек таржимачилигида биринчилар қаторида фикр-мулохаза юритади.

Олим китобнинг кейинги бобларида рус ва ўзбек таржимашунослигида маълум бўлган анъанавий муаммолар ечими устида тухталаркан “Лексик бирликлар ва таржима”, “Миллий хусусият ва таржима”, “Таржимада нутқий хусусият”, “Образли лисоний воситалар ва таржима”, “Фразеологик бирликлар ва таржима”, “Бадиий таржима ва нутқ маданияти" масалаларини тахлил қилишга уринади. Профессор Қудрат Мусаевнинг ушбу дарслик-монографияси XXI аср бусағасида таржима назариясини умумфилологик фан сифатида эътироф этган биринчи йирик тадқиқот тарзида бахоласак арзийди.

Таржимашунослик илмининг иккинчи маркази Ўзбекистон фанлар академияси, Тил ва адабиёт институтининг Таржима назарияси ва адабий алоқалар секторида шаклланган эди. Сектор мудири профессор Ж.Шарипов рахбарлик қилган ушбу илм масканида унинг рахбарлигида Ж.Юсупов [10,12], М.Холбеков [11,19], Х.Маматова, С.Одилова, Б.Ильясов, Р.Абдуллаев, А.Аллаберганов, Е.Хамроев, С.Шукруллаевалар номзодлик диссертацияларини химоя қилдилар. Бу диссертацияларда кўпроқ хусусий таржима назарияси масалалари тадқиқ этилди. Масалан Ж.Юсупов қардош тиллардан таржима қилиш муаммоларини туркман-ўзбек таржима объектида тахлил қилган бўлса, олим Мухаммаджон Холбеков француз прозасидан ўзбек тилига ўгирилган таржималар тарихини яратиш билан француз-ўзбек таржима масалаларини ёритиб берди. Равижон Абдуллаев ва А.Аллабергановлар немис адабиётидан шеърий таржима, яъни Ф.Шиллер ва И.В. Гёте асарлари таржималарини тахлил қилишди. Ё.Хамроев ва С.Шукруллаевалар инглиз-ўзбек (Э.Хемингуей) ва ўзбек-инглиз (“Бобурнома”) тилларига таржима амалиётини аслият билан қиёслаб ўргандилар. Албатта бу тадқиқотлар хам А.В. Федоров, И.Кашкин, Г.Гачечиладзе, И.Левый , Ж.Шарипов, Ғ.Саломов, Н.Владимирова, Қ.Мусаев тадқиқотларида кўтарилган таржима назариясининг тилшунослик ва адабиётшунослик муаммолари атрофида яратилган эди.

\section{Адабиётлар:}

1. Ďurišin D. a kol. Osobitne medziliterarne spolocenstva. Bratislava, 1987 (Проблемы особых международных общностей. Под ред. Д. Дюришина. М. 1993)

2. Салямов Г. Литературные традиции и проблемы художественного перевода (сопоставительный, стилистический и типологические аспекты). АДД. 1982.

3. Саломов Ғ. Адабий анъана ва бадиий таржима. - Тошкент. “Фан” нашриёти, 1980.

4. Раббанақулов Р. Ўзбекистонда таржимашунослик илмининг тараққиёти. АКД. Тошкент, 2000.

5. Абдуазизов А., Холбеков М. Атоқли таржима назариётчиси (проф. Ғайбулла Саломов портретига чизгилар)// “Ўзбек адабиёти ва санъати” газетаси, 2015, 12 март.

6. Гафурова Г. Перевод как средство взаимодействия литератур (проблемы художественного перевода с узбекского на русский язык). АДД. 1981.

7. Комилов Н. Хорезмская школа перевода: проблемы типологии и сопоставительное исследование истории перевода. АДД, Ташкент, 1987.

8. Мусаев К. Лингвистические проблемы перевода. АДД. - Тиблиси, 1988.

9. Мусаев Қ. Таржима назарияси асослари. Монография. - Тошкент: “Фан” нашриёти, 2005. 
10. Юсупов Ж. К проблеме перевода с родственного языка в аспекте воспроизведения национального своебразия оригинала. АКД. - Ташкент, 1980.

11. Холбеков М. Французкая художественная литература в переводе на узбекский язык (история и переводческий опыт). АКД.-Ташкент, 1982.

\section{ГУРУЧЛИ ТАОМЛАРНИНГ \\ БАЪЗИ БИР ЛИНГВОКУЛЬТУРОЛОГИК ХУСУСИЯТЛАРИ}

\section{Пирматова Озода Сафбарбоевна \\ Урганч Давлат университети ўқитувчиси \\ E-mail:ozodaustoz80@mail.ru}

Annotation: This article discusses the lingvoculturological properties of rice-related foods. In particular, in the Khorezm oasis an attempt was made to study the traditions associated with it.
Key words : rice, ritual,

lingvoculturology, food, etymology, pilaf, tradition, dialect.

Хар бир миллатнинг ўзига хос урф-одат, маросимлари мавжуд. Ушбу урф-одатлар, маросимлар ўша миллатнинг менталитети, характер, хусусияти, маънавий олами, қадимдан шаклланиб келган миллийлик хусусиятлари билан боғлиқ. Ўзбек халқида урф-одатлар ўзаро хамжихатлик, бирдамлик, дўстона муносабат, каттага хурматда ва кичикларга иззатда бўлиш тамойили асосида шаклланган. Тўй ёки мотам маросимларида турли таомлар тайёрланади. Гуручли таомлар шулар жумласига киради. Бундай таомларнинг тайёрланишида хам рамзийлик бор. Жумладан, тўй маросимида келин тушганда, мехмонларга "ширгуруч" тайёрланади. Ушбу таом Хоразм шевасида “сутбурунчи, сутурунчи" каби номлар билан аталади. Унга оқлик, яхшилик сифати берилади [2. 50 б].

Никох тўйида тўй куни куёвникида тўй оши (палов) тайёрланади ва келинникига юборилади, у ерда палов дастурхонга тортилади. Худди шундай ош куёвнинг уйида хам тайёрланади.

Никох тўйидан кейин “куёв кўрар” маросими ўтказилади. Бунда келин эрталаб туғилиб ўсган уйига борилади. Кечқурун эса қуда томонидан бирор таом тайёрланиб келиннинг уйига мехмонга боришади. Келин уйида қудалар учун биринчи таомга ширгуруч, кейин бошқа бир овқатлар тортилади. Пайғамбар хам куёвни сийлаган, иккала ёшнинг хаёти оқ бўлсин, ширин бўлсин, деган маънода [2. 64 б].

Шунингдек, пайшанба куни Хоразмда сутгурич, яъни ширгуруч пиширилади, ушбу таом пайғамбарлар оши, шу куни барча дуолар ижобат бўлади, деган рамзийлик берилади[2.51 б].

Пайшанба ва якшанба кунлари эса палов пиширилиб овқатни еб бўлгач, ёғи қошга ва махсига суртилади. “Ширин хаёт, манзил обод, худоға, пайғамбара саловот. Кўп бер кўл бер. Кенг феъл, кетмас давлат бер. Дўстга зор, душмана хор номарта мухтож қилма. Ўт балосиннан, сув балосиннан, нохақ тухматдан, кўринар кўринмас офатдан ўзинг асра, экканни, тикканни, еганни, ичганнинг савобини даргохингда қабул эт. Омин, аллоху акбар!”, деб ният қилинади [2.66 б].

Хоразмда садақа беришганида “қарма" таоми тайёрланади. Унга гўшт махсулоти жуда кўп солинади. Уйда пишириладиган таом эса “шавла" дейилади. “Шавла” жуда суюқ бўлса халқ орасида "икма шавла" дейилади.

Хоразмда мархумнинг учинчи пайшанбалик маъракасида хам ширгуруч [сутбурунч] пиширилади.

Халқ орасида гуручли таомлар билан боғлиқ турли урф-одатлар хам мавжуд. Жумладан, тиниб-тинчимайдиган ёки бир ёшга тўлгач хам хали юрмаган болани устига гуруч ёйилган матога ўтирғизишади. Бола тез юрсин ёки тинчимайдиган бола гуруч ўйнагач босиқ бўлсин, деган маънода. 
Шунингдек, гуруч суви гулга солинса тез ўстириши, юзни таранглаштириши, сочни ўстириши билан боғлиқ урф-одатлар хам мавжуд.

Гуруч ёки унинг суви табобатда хам ишлатилади. Тиззага туз йиғилган бўлса, майда гуруч, яъни “сечка" си(увоғи)дан бўтқа тайёрланиб, иссиқ қилиб боғланса тузалади, боланинг яра-чақа чиққанда, яъни касалланганда хам тез тузалсин учун гуруч майдаланиб оғзига сепилади. “Шавла" таоми бел умуртқаси оғриганда белга боғланади. Бола “қарамиқ” касали билан оғриса, касаллик енгил ўтиши учун сутбурунч таоми пиширилади, ушбу таом қўшниларга тарқатилади.

Мусулмонлар одатига кўра 63 ёшга тўлганда хам “пайғамбар ёши" деб, “сутбурунч" пишириб тарқатилади.

Мамлакатимизнинг баъзи жойларида, хусусан Тошкент шахри ва унинг атрофларида эрталабки "ош маросими" тўй (суннат тўйи ёки никох тўйи) ва аза маъракасида (ўлимдан кейин 20 кун хамда бир йилдан кейин) ўтказилади. Маъракани ўтказувчилар эрталабки ошнинг куни ва вақтини аввалдан махалла ахли билан келишилган холда белгилайдилар. Эрталабки ош бомдод намозининг тугаши пайтигача тайёр бўлиши лозим, чунки намоздан чиққан кишилар биринчи мехмонлар бўлади. Эрталабки намоз тугаган пайтда карнайсурнай ва ноғора овозлари эрталабки ош бошланганидан хабардор этади. Мехмонлар дастурхонга ўтириб, фотиха ўқиганларидан кейин уларга нон ва чой тортилади. Шундан кейингина лаган(товоқ)ларда икки кишига бир лаган(товоқ) хисобида ош сузилади. Ош ёйилгандан кейин лаган(товоқ)лар олиниб, баъзи қипчоқ лахжаларига мансуб худудларда эса таомни дастурхон қўйгач, у истеъмол қилмасдан олдин хонадонда ўтган кишилар рухига фотиха ўқилади.

Oш, палов сўзлари эквивалент сифатида ишлатилади. Палов сўзининг этимологияси хақида хам турли хил фикрлар мавжуд. Бу от ПРСда [полоу] шаклида (96), ТЖРСда палав шаклида (296) келтирилган; ўзбек тилига тожикча шакли в товуши олдида келган $a$ товушини $о$ (ä) товушига алмаштириб олинган; “гўшт, пиёз, сабзини ёғда қовуриб, қайнатиб, гурунч солиб, яна бироз қайнатиб, дамлаб пишириладиган миллий таом" маъносини англатади (ЎТИЛ, I, 569) [1. 181 б].

Палов ( айрим қарлуқ ва қипчоқ лахжаларида ош хам дейилади. Хозирда ош термини маъноси кенгайганлиги билан характерланади. Чунки ош барча иссиқ овқатларга, яъни таомларга нисбатан хам ишлатилади). Ош оти ПРСда [aш] шаклида келтирилиб, "суюқ овқат”, “емиш" маъносини (25), ТжРСда ош шаклида келтирилиб, “иссиқ овқат”, "палов” маъноларини англатиши айтилган. Кўринадики, кейинги пайтларда "палов"термини маъноси анча кенгайган ва ўзига хос янгича маънолар англата бошлаган [1.175 б].

Демак, ўзбек халқи жуда хам пазанда бўлиб, ўзининг турли-туман таомлари билан дунё халқлари ичида ўз ўрнига эга. Уларнинг тайёрланиши ва номланиши хам ўзига хос. Ушбу таомлар оилада кундалик хаётда, турли маросимларда тайёрланади. Айниқса, гуруч билан боғлиқ таом номлари, улар билан боғлиқ маросимлар, урф-одатларнинг лингвистик хусусиятлари хамда этимологиясини тадқиқ қилиш лингвокултурология фанининг мухим масалаларидан биридир.

\section{Адабиётлар:}

1. Ш. Рахматуллаев. Ўзбек тилининг этимологик луғати. Тошкент, 2009 йил

2. Хоразм фольклори. ХІ том. Урганч, 2010 йил 


\section{ЭДГАР АЛЛАН ПО ИЖОДИДА МУХАББАТ ТАРАННУМИ}

\section{Расулова Сохиба Улуғбековна \\ Самарқанд давлат чет тиллар \\ институти ўқитувчиси \\ E-mail: rasulovasokhiba@gmail.com}

Annotation: The articleis dedicated to the work of author Edgar Allan Poe and praises the ideas of love in his work. The article is illustrated one of the brightest representatives of Western romanticism which began to fade in Europe but was renewed in America that poet has been the founder of the fiction-detective genre in American Literature
Key words : love, national pride, national spirit, international simplicity, deep gaze, lyrical hero, ideological goal.

Эдгар Аллан По ижоди XIX аср Америка ва Европа романтизм адабиётида залворли ўрин эгаллайди. Адиб ўз замондошлари Ф.Купер, Н.Хоторн, Х.Лонгфелло қаторида АҚШ адабиёти тараққиётига катта хисса қушшди, унинг яратувчиларидан бири бўлди. Эдгар По Европада сўна бошлаган, аммо Америкада янгиланган Ғарб романтизмининг ёрқин вакилларидан бири, Америка адабиётида фантастик-детектив жанрга асос солган ижодкор хисобланади. Эдгар Аллан По XIX асрнинг 40-йилларидаги америка шеъриятнинг таниқли вакилларидан бири, қалами ўткир, фикри теран шоирлардан эди.Эдгар По даврида Америка “адабий қароқчилар мамлакати эди" деб аталарди. Муаллифлик хуқуқи мавжуд эмасди, ёзувчилик эса касб хисобланмас эди. АҚШ барча ёзувчилари у ёки бу даражада таъминланган кишилар бўлишган: Куперкатта ер эгаси, Готорн - давлат хизматчиси, Эмерсон-пастор, Лонгфелло - университет профессори, Холмс-таниқли тиббиётшунос бўлган. Эдгар По Америкадаги биринчи бўлиб қалам хақи хисобидан кун кўрувчи, ноширлик ишидаги нафси хақалак отганларга тобе бўлган ижодкор хисобланади. У бир умр фақатгина моддий фойда келтирибгина қолмай, кўплаб ёш махоратларни етиштира оладиган шахсий журнал хақида орзу қилган (Бу менинг хаётимдаги энг катта мақсадим, мен буни бир дақиқага хам унўтмайман.1849 йилнинг апрел ойида ўзининг журналини ташкил қилиш режаларин туза туриб Петерсонга шундай ёзади: “Жамиятнинг интелликтуал қатламларига мурожаат қилиш керак...”.Аммо буни амалга ошириш учун По молиявий кўмакка мухтож эди.

1840 йилда у “Гротеск ва Арабеск эртаклари" («Tales of the Grotesque and Arabesque») номли икки жилдли хикоялар тўпламини нашр эттирди, аммо бу хам унга молиявий кўмак бера олмади. Яхши хаёт қидириб Эдгар По шахарларни кўп алмаштирди: Ричмонд, Нью-Йорк, Филадельфия, Вашингтон ва яна Нью-Йорк. По нафақат шеърлар, хикоялар, балки кўплаб адабий ва танқидий мақолалар ёзса хам унинг турмуш тарзига таьсир қилмади.

1845 йилда унинг “Қарға ва бошқа шеърлар" ("The Raven") номли назмий тўплами нашр этилди.Унинг шухрати тобора ўсиб бормоқда, лекин унинг молиявий ахволи ўша ўша. 1846 йилдан Эдгар По ва унинг оиласи учун энг оғир даврлар бошланди. Марузаларни тўхтатиб у доимий маошдан айрилди ва тушкунликка тушиб қолди.Оиласи янада қашшоқлашди.1846 йил декабрь ойида "New York Morning Express" газетасида Эдгар По ва унинг рафиқаси касаллиги ва уларнинг оилавий ахволи хақида хабар пайдо бўлди. Хабар ёзувчи дўстларини оғир пайтда унга ёрдам беришга чақириш билан якунланган. Шоир хайр-эхсонларни қабул қилишга мажбўр бўлди; Виржиния ялонғоч холатида, сомон тўшагида, совуқ кулбаларнинг барида хаётдан кўз юмди. Эдгар По аламларини шароб билан тўкди. Адабиётдаги душманларининг аёвсиз хужумларига қарамасдан ўз фаолиятидан тўхтатмади. 
Хаётининг сўнгги йилларида По энг яхши шеьрий асарларини яратди: “Қўнғироқлар” ("Bells", 1849), “Анабель Ли” ("Annabel Li", 1849); “Эврика” ("Eurika", 1848), астрономик ва фалсафий асар “ва яна бир қатор сатирик эртаклар.У омма олдида марўзалар ўқиди, уларда ўзининг эстетик қарашларини тарғиб этди.

Ўз амакиваччасининг қизига, Виржиния Клемга, эрта уйланиб (қиз ўн тўрт ёшда бўлади) оиласини амалда қайнонаси -аммаси боқишидан азият чекади. Виржиния туберкулёз билан оғриб қолади ва ўлим билан курашади. Эдгар По ўзининг ожизлигидан қийналиб кетади, ақлдан оза ёзади. Мехнат лаёқатини йўқотиб боради, барчасини унутиш учун вино ва опиумга зўр беради.

Бироқ ичимлик унинг сохлигига шу қадар зарар етказгандинки, у кўпинча ўзини унутиб қўяр эди."Хеч нарса менга ёқмай қолди, менинг хаётим бехуда кетди-1849 йил май ойида Анна Ричмондга шундай ёзади,-келажакни жуда хира куряпман, аммо мен барибир курашаман ва умидим яна тикланади".

Қашшоқлик ва омадсизликларга қарамай Эдгар По ўзини йўқотмади.Унинг хаёти қай даражада аччиқ бўлганлигидан унинг сўнгги ойлардаги хатлари хабар беради; улардан ноумид садолар эшитилади. “Бу ерда яна икки доллар топдим уларни сизга юбораяпман,- деб ёзади По Клемм хонимга,-Эй Худо,онажон яна учрашамизми? Иложи бўлса келинг, мен қаттиқ бетобман".

Унинг ўлими сирли юз берди. Ричмондда “Шеьрий тамойил” мавзусида маьрўза ўқиб катта миқдорда пул олганидан кейин По Балтимор шахрига келди ва у ерда бир неча кундан кейин кўча ўриндиқларининг бирида бехуш холатда топилди; унинг маст бўлганлиги ва талон тарож қилинганлиги тахмин қилинади.1849 йилда Эдгар Аллан По Балтимор касалхонасида мияга қон қуюлиши сабабли вафот этади.

Бу асл ёзувчининг асарлари адабиётда ўша даврларда хукм сўрган романтизм йўналишга мос келади.У хаётнинг патриархал нормалари бузилган ва тез ривожланаётган капитализмнинг шаклланиш даврида яшади.Ўша пайтда АҚШда биринчи темир йўллар қурилди, божхона ва қуллик масалаларида шиддатли кураш, Мексика билан уруш бошланди.

Эдгар По қулдорлик мавжуд бўлган штатда туғилиб улғаяди ва жанублик қулдор-плантаторларнинг айрим фикрларигагина кўшилади. У ўзи киноя билан таъкидлаган “негр уруғи кўкатларини” ўстирмаган, типик пролетар-зиёлиси эди. Аммо ўз дунёқарашига қарамасдан у қул ва қулдор, унинг боласи ва негр энагаси ўртасида узвий алоқалар мавжуд, уларнинг кескин узилиши, гуманизмга зиддир, деб хисоблаган. Унинг ижодида хам қул ва эгаси ўртасидаги патриархаль муносабатларни химоя қилиш оханги кузатилади. “Тилла қўнғиз” («The Gold Bug», 1843) хикоясида негр қул Юпитер образадигаи комик жихатлар унинг ўз хўжасига қанчалик садоқатли эканлигини кўрсатиб туради. Аммо хўжайин ўз эркинлигини суиистьемол қилса, уни савалаш учун дарра тайёрлаб қўяди. По негрлар билан оила аъзоси сифатида муносабатда бўлишни таклиф қилиб, пишиб-етилган зиддиятни юмшатмоқчи бўлади, унга фақат эстетик жихатдан қарайди.

“Жанубликлар” билан ёзувчини бошқа нарсалар хам “боғлайди”. АҚШ жанубидаги инглиз аристократияси авлодлари йўқсилликка учрашса хам, ўз имтиёзларига ёпишиб олишган, ўзларини нозик маданият ворислари хисоблашиб, геральдикалари билан ғурурланишган. Жанубда бу холат шунчалик “жони қаттиқ”лик қиладики, хатто ярим аср ўтиб хам хажвчи Марк Твен жануб задогонларининг “киборликларини" ўзининг “Америкалик номзод” асарида аччиқ кулгуга олади. Дастлаб ёпиқ инглиз пансионида, сўнгра ричмондлик киборлар даврасида ўралашиб улғайган Эдгар По Жанубга хос услубни ўзлаштиради, ўзини хам "киборлардан" хисоблайди, аммо моддий ва ижтимоий жихатлардан у хеч қачон бу давраларга алоқаси бўлмаган. 
Воқейликни эстетик бахолаш ва саньатнинг хаётдаги ролини белгилашдан Эдгар Понинг буржуа Америкаси билан келишмовчилиги бошланди.

“Пул жазманлари” дея Эдгар По тадбиркорларни атайди.; унинг фикрига кура доллар америкаликларнинг байроғига айланган, агар АҚШда келиб чиқиши кибор бўлганлар бўлмаса хам, “доллар аристократлари, бойлик билан мақтанувчилар” кўп топилади.

Фақатгина фойда, даромад олиш шиор хисобланадиган бу оловли дунёда шеьрият ва гўзаликка жой йўқ. Бу ўртада эса хақиқат камёб ва кадрсиздир. Лекин инсон гўзалликка мухтождир. Бадиий адабиёт билан танишиш кўнгилни кўтарадиган кувонч бахш этади, дея тасвирлайди Эдгар По “Композиция фалсафаси” мақоласида («Philosophy of Composition»,1846).

Адибнинг ишончли фикрлари гўзаллик ва улуғворликка йўғирилган эди.У туйғуларни шиддатли акс эттирищга харакат қилган, аёлларни доно ва чиройли фаришталар сифатида тасвирлаган. Қадимий маьнавий қадриятлар дунёсини адабиётга жо этиш кераклигини хис этган.Унинг фикри бўйича эски қадриятлар дунёсининг сифатлари факатгина АКШнинг Виржиния ва Мериленд штатларида сақланиб қолган.

Адабиётлар:

1 Poe.E.A. The complete poetical works. Ed. by A.B.Johnson-London: Oxford University. 1919-LX. $316 \mathrm{p}$ 2.По. Э.А Избранные произведения: В2-х Томас - М: Худож. лит,1972

3.Poe. E.A. Collected works of Edgar Allan Poe. Vol.1, Cambridge (Mass.), The Belknap press of Harvard univ. press, 1969.

4. М. Холбеков. Эдгар По ва юлдуз қисмати."Ўзбекистон адабиёти ва санъати" газетасининг 2009 йил 24-сони.

\section{NEMIS SHOIRI GENRIX GEYNENING \\ “LORELEY” SHE'RI O'ZBEKCHA “SUV PARISI” TALQINIDA}

Toshpo'latova Nargizaxon Mamarizayevna Xalq Ta'limi Vazirligi Farg'ona viloyati XTXQTMOHM o'qituvchisi

Annotation: In this article says about poet Heinrich Heine who, he was born in 1797 year in City Dusseldorf State Germany and facts his Poem "Lorelei" and translation.

Key words: Volksongs ,century, Poem, great, literature, work

Buyuk nemis shoiri Genrix Geyne 18-19 asrlarda nemis adabiyoti gullab, yashnagan davrida o'zining ijodi bilan nemis adabiyotiga kirib keldi.Genrix Geyne 1797-yil 13-dekabr kuni Germaniyaning Dyusseldorf shahrida tug'ilgan. U ijodiy faoliyatini boshlab, romantik,lirik she'rlari va xalq qo'shiqlarini 1821-yilda yozdi. Geyne dastlab Bonn va keyinroq Gottinger va Berlin Universitetiga borib,shu vaqtning o'zidayoq adabiyot,sana't,falsafani o'qib o'rgandi.1825 yilda oliygohni tamomladi.U hamma she'rlarini 1817-1826 yilda yozib tugatdi. Keyinroq „Qo'shiqlar kitobi“da jamladi.1824- yilda u 1- proza asari „Gersga sayohat"ni yoritdi.Uning buyuk asarlari "Vaqt she'rlari" va siyosiy she'ri "Germaniya.Qish ertagi“ xalqchil, romantik,mumtoz top'lamlaridir.U o'zining asarlari, shoirlik ijodi bilan nemis she'riyatga ulkan hissa qo'shdi hamda yanada rivojlantirdi. GenrixGeyneningshe'rlarihaqiqatdanhamuningmahoratlishoirekanligidandalolatdir.

\section{Lorelei.}

(Heinrich Heine)

Ich weiss nicht was soll es bedeuten,

dass ich so traurig bin; ein Märchen aus alten Zeiten, das kommt mir nicht aus dem Sinn.

\section{Suv parisi}

( Nargiza Toshpo'latova tarjimasi) .

Nima bo'lganin bilmay,

Men g'am-anduh chekaman.

Uzoq davrdan qolgan ertak, Mening yodimdan hech ketmas Havo salqin va qorong'ilashmoqda, 
Die Luft ist kühl, und es dunkelt, und ruhig fliest der Rhein; der Gipfel des Berges funkelt im Abendsonnenschein. Die shönste Jungfrau sitzet Dort oben wunderbar, ihr goldnes Geshmeide blitzet, sie kämmt ihr goldenes Haar. Sie kämmt es mit goldenem Kamme Und singt ein Lied dabei: Das hat eine wundersame, gewaltige Melodei. Den Shiffer im kleinen Schiffe Ergreift es mit wildem Weh, er schaut nicht die Felsenriffe, er schaut nur hinauf in die Höch Ich glaube,die Wellen verschlingen Am Ende Schiffer und Kahn; Und das hat mit ihrem Singen Die Lorelei getan.
Reyn daryosi ham sokin oqmoqda.

Tog'larning cho'qqisi ham yaltiramoqda, Kechqurun, oqshomqosh qoraygan vaqtida

Bir go'zal qiz o'ltirardi

U o'sha ajoyib tepalikda.

U go'zalning kokillari yaltiirardi, Sochlarin ham shu chog'da tarar edi. Ul pari sochlarini oltin taroqla tarar edi, Va yana shu on go'zal qo'shiq kuylar edi.

Shunday qilib ajoyib ohangrabosi bilan o'ziga tortuvchi bir kuy paydo bo'lgandi.

Kichik qayiqdagi qayiqchini

Bir ajoyib his, qo'rquv chulg'ab olgandi.

Va u qoyatoshlarga emas hamon,

Boqar o'sha yuqori tomon.

Men o'ylaymanki, to'lqinlar toshib ketdi, Qayiq va qayiqchilar daryoga g'arq bo'lib ketdi.

Shunday qilib u qizning qo'shig'i ila, Lorelay ham shundan buyon paydo bo'ldi.

“Lorelay” bir afsonaviy qiz bo'lib ya'ni u o'zbek tilidagi „Suv parisi“ kabidir. Ushbu afsonalar orasida Geyne o'zining „Lorelay“she'rini yozgan. Xalqning o'y-hayollari tarixiy hodisa sifatida bezatilib, sh'eriy tarzda aks etgan.

Alois Schrayber quyidagilarni ta'riflagan. Lorelay -Suv parisi .

Reyn daryosi yaqinida Lorelay qoyasi bor. Nemis xalq afsonasida aytilishicha, odamlar tez-tez o'sha qoyada bir qizni ko'rishgan.U qizning ismi Lorelay bo'lib, oqshom tushgach, qoyaga kelib bir ajoyib qo'shiq kuylardi. Go'zal qiz qo'shiqni shunday chiroyli kuylardiki,baliq tutgani kelgan baliqchilar Reyn daryosiga tushib, cho'kib ketardilar. Chunki, ular faqat go'zal parining qo'shiqlarini tinglashar, qoyalarni ko'rishmasdi. Ba'zan go'zal pari daryoning qirg'og'iga kelib baliqchilarga qayerdan baliq tutish kerakligini aytardi ham. Baliqchilar har yerda chiroyli nozanin, nafis qiz haqida aytib yurardilar.Bir kuni bir grafning o'g'li Suv parisi haqida eshitib qoldi.U o'zi u qizni ko'rishni istadi. U bir qayiqni oldida hamda Lorelay qoyasi yaqiniga keldi.Ushbu dam go'zal oqshom edi. Osmon tiniq oy ham yorug', yulduzlar ham nur taratib turardi.Shunda grafning o'g'li to'satdan qoyaning yuqorisida go'zal qizni ko'rib qoldi.Shu payt u qiz oltin sochlarini tarab, qo'shiq kuylar edi.Grafning o'g'li qayiqda qirg'oqqa yaqin kelganda yerga sakradi, ammo u suvga tushib ketdi.Shu bilan uni hech kim qaytib ko'rmagan.Keksa Graf o'glining o'limidan xabar topgach, o'z odamlarini chaqirib dedi:"Menga osha qizni tirik yoki jasadini olib keling!".Keyingi oqshom grafning odamlari Lorelay qoyasiga keldilar.Ular qoyaga chiqdilar. Shunda to'satdan, bir qizning tovushini eshitishdi.

„Kimni qidiryapsizlar, bu yerdan yerdagi odamlar?“ dedi suv parisi.

„Seni qidiryapmiz,--deya javob berishdi odamlar. Shunda Lorelay kulib dedi:“Qani tutib olinglarchi meni!“ Yana qo'shiq kuylashni boshladi.

To'satdan osmon butunlay qorong'ilashdi, dovul boshlandi. Reyn daryosidan ikki to'lqin qoyaning cho'qqisigacha ko'tarildi.Bu to'lqinlar huddi otlar kabi parini daryodan yuqoriga ko'tardilar.Grafning odamlari esa to'lqinlarda vafot etdilar.Shu kundan e'tiboran go'zal pari Lorelay qoyaga kam keladigan bo'ldi.

1.Lesebuch zur Geschichte der deutschen Literatur.

\section{Adabiyotlar:}

2.Deutsch. I.L.Bim. E.I.Passow.Lehrbuch.Lesebuch. Moskow."Verlag"1990 J.

3.Lesebuch. Verlag"Prosvesheniye“ 1974 Jahre. Seite 64,65,66, . 


\section{Турсунова Наргиза Хамрокуловна \\ Самарқанд Давлат Чет Тиллар Институти ўқитувчиси \\ E-mail:_tursunova@samdchti.uz}

Annotation: The article highlights the work of Albert Camus, an existentialist writer and moralist philosopher of the twentieth century. The author of the article touches on the question of the stages of the French writer's creativity: the first stage is the cycle of the Absurd; the second stage was called the cycle of Revolt by Camus himself; the third stage is the cycle of love, or Nemesis. Unfortunately, the third stage of the work was never completed due to the premature death of Camus in a car accident in 1960.

Камю ижодининг биринчи даври “Абсурд давр” деб номланган (Сycle de l'Absurde), бу даврга унинг “Сизиф хақида афсона” номли эссеси (1942), “Бегона” (1942), “Англашилмовчилик” (1944) ва “Калигула" (1945) номли драмаси киради. Ижодиниг бу даврида асосий мавзу “абсурд” бўлади ва у турли вазиятларни қамраб олади, баъзида кутилмаган режалар тузади: афсонавий (Сизиф образи), Худо билан тенглаштирилган ("ягона Христос тенглаштирилган" - Мерсо); ақилсизлик билан хам тўқнашамиз, бемани император Калигул, куракда турмайдиган вазиятлар, текин даромад учун қотиллик кабиларни (“Англашилмовчилик”, 1944) асарларда учратиш мумкин. Камюнинг ўзи ижодининг биринчи даврига “абсурд хукумронлик қилади, мухаббат қутқаради" деб формула тузади.

Камю ижодининг иккинчи даври “Исён” бу даврга: “Исёнчи одам" (1951) эссесини киритади, бу асарида муаллиф қўзғолончилар харакатига таъриф беради: “Йуқ” дейдиган одам" , “Вабо” (1947) аллегорик романи, фашистларга қарши қўйилган “Адолатпарвар" (1949) эссеси ва “Қамал холати” (1948) номли асарлари киради. А. Камю ижодини ўрганувчи адабий танқидчи шундай ёзади: “Ўз-ўзини бахолаш жуда қийин. Бу ўтмиш билан видолашишга ўхшайди: бошқача бўлиш учун самимий эхтиёж кечаги ўзи хақида чиқарилган хукумлардаги каби бўлиб қолишни талаб қилади. Камюнинг “Немис дўстига ёзган мактублари”да ва қисман “Тушунмовчилик”да олиб борган қарашларни аниқлаштириш уришдан сўнг дархол тугади, чунки у ўзининг навбатдаги ижодий босқичига кўтарилиши “Исён доираси” да деб бахолади $[1,99]$.

Учинчи давр “севги”, ёки Немезидани ўз ичига олади: авлодининг тарихий тақдирига бағишланган “Биринчи одам” романи, “Дон Фауст” пьесаси. Немезида образи муаллифнинг ижодий онгида ўлчов ва адолат ғоясини акс эттиради, Сизиф “абсурд” каби, Прометей эса - “исён”. 1950 йилларда Камю “Қувғин ва қироллик” (1957) қисқа хикоялар тўплами ва “Ағдарилиш" (1956) романини яратди.

Шундай қилиб, Камю ижодий тафаккурининг эволюцияси даврийлигини тиклаш мумкин: “илк ижоди” (1932-1938), “абсурд” (1933-1941), “исён” (1941-1952), “севги” (1952-1960) йиллар.

1947 йилда Камюнинг "Вабо” » (La Peste, 1947) романи нашр этилди. “Вабо" романига сўзбоши сифатида муаллифнинг ўзи шундай деб ёзади: “Абсурд хисси,агар харакатлар қоидалариундан олинса, қотилликни хеч бўлмаганда бефарқ қилади ва шундай қилиши мумкин. Агар ишонадиган хеч нарса йўқ бўлса, агар бирон бир нарсада маъно бўлмаса ва бирон бир нарсанинг қийматини тасдиқлашниг иложи бўлмаса, унда хамма нарса жоиз ва хамма нарса мухим эмас. Хеч қандай яхши томони хам, ёмон томони хам йўқ, қотил хам тўғри хам, нотўғри хам эмас. Сиз крематория печларини иситишингиз мумкин, моховларни даволашни амалга оширишингиз мумкин. Ёмонлик ёки яхшилик - бу шунчаки имконият ва инжиқликтир"[2, II, 415]. 1955 йилда Камю: “Бегона” билан таққослаганда, “Вабо”, шубхасиз, ёлғиз исёндан тортиб биргаликда курашиш керак бўлган жамоани тан олишни англатади. Ва агар “Бегона” дан “Вабо”га 
қадар эволюция бўлса, у бирдамлик ва хамжихатлик йўналишида содир бўлади" деган фикрда қатий турди [3, p.1966]. Шунга қарамай, “абсурд” яна ижоднинг ушбу босқичи марказида тургани аниқ. Адабиётшунос Д. Наливайко Камюнинг "Вабо” романини шундай тарифлайди: “Камюнинг ушбу асари ибратли роман бўлиб, у сўнгги интелектуал насрда кенг тарқалаган, универсаллиги, кўпмаънолиги, мазмуни билан ажралиб турадиган жанрга тегишли. Бундан ташқари “Вабо”, “Жараён” ва Кафканинг “Қалъа"си, Платоновнинг “Чукур”и, Голдингнинг “Чивинлар шохи” бу жанрдаги энг катта ходисалардан биридир.

А. Камю асарларини яқиндан ўрганган рус адабиётшуноси С. Великовский роман хақида қуйидагича сўз юритади: “Вабо совуқ, хатто камбағал китоб бўлиб, унда лирик гумбазлар хрониканинг бефарқлиги билан бостирилади ва воқеаларнинг драматик намойиши бу ерда портретли эскизлар керак бўлган одамлар рўйхати, таржимаий холлари каби эслатма сифатида намойиш этилади, шахсий маълумотлари ва қахрамонлари жонли бўрттиришларга, рухий мустахкамликка эга эмаслар, охироқибат, айтиш мумкинкибу китоб бироз кўнгилочар ва зерикарлидир.Тақиблар, четдан қараганда, бир қарашда хақиқатпарвар ... “Вабо" - бу ахлоқшунос- тахлилчининг китоби, аниқ улардан бири Франция учун унчалик истисно бўлмаган холатлардан, агар спекуляция адабиётга аралашмаса аксинча уни озиқлантирса. У кўп асрлик маданий анъана асосида ўсган Монтень, Ларашфуко, Монтескье, Вольтерларнинг манбааларидан эди [1, 118-119]. Бу хақиқатдан хам шундайми? Буни аниқлашимиз лозим.

Романнинг эпиграфида у фантастик қиссага нисбатан муаллифнинг эркилигини таминлайди: «Il est aussi raisonnable de représenter une espèce d'emprisonnement par une autre que de représenter n'importe quelle chose qui existe réellement par quelque chose qui n'existe pas » (Daniel Defoe, écrivain anglais, 1660-1731). - “Агар озодликдан махрум этишни бошқа қамоқ жазоси билан тасвирлаш жоиз бўлса, унда хақиқатдан хам мавжуд бўлган бирон бир нарсани умуман мавжуд бўлмаган нарса орқали таъсвирлаш жоиздир" (инглиз ёзувчиси Даниель Дефо, 1660-1731). Шубхасиз, романда гап юқумли кассалик вабо хақида эмас “194...йилда Жазоирда” тўсатдан пайдо бўлган шунга ўхшаш фалокатни назарда тутади, муаллиф аллегория (белги) сифатида одамларни вабога ўхшаш нарса тақиб қилаётганини англашини истайди. Бундан ташқари, роман номининг талқинлари жуда кўп, жумладан: уруш, Худонинг жазоси, инсоннинг ўз айби , бахтсизлик кабилардир.

Замон ва макон. Муаллиф романинг биринчи сатрларида ва ёзилиш вақтида (1940 йил охирида - 1942 йил бахорида) кўрсатилган асарнинг хронотопи (194...), шунингдек, асар нашр этилган сана (1947) бу нуқтаи-назардан вабо уруш билан боғлиқлигини аниқ кўрсатиб турибди. Иккинчи жахон уруши (1939-1945) бутун дуёни ларзага келтирди ва хар бир инсоннинг хаётига таъсир қилди. Тажрибали ақл эгалари ва ёзувчилар ушбу бахтсиз ходисани тушинишга ва тахлил қилишга, уларнинг аксарияти сиёсий “одилона" (“одилона” - номақбул ўз мнфаати учун, ўзининг аниқ сиёсий позициясини химоя қилиш) харакат қилмоқдалар. Романда вабо ва иккинчи жахон уруши ўртасидаги параллелга ишора қилувчи тафсилотлар: “Оран” “ёпиқ шахар” («ville fermée») сифатида тақдим этилган, деярли денгиз йўқ, каламушлар томонидан қўлга олинган, кейинчалик эса касаллик (муаллиф асосан “босқинчилик” «invasion» сўзидан фойдаланади) [4, p.p.19,72]). Асарда тасвирланган вазият, Франция нацистлар армияси томонидан босиб олинган хақиқий воқеаларга асосланади.

Фашистлар армияси “жигарранг вабо” (немис армияси формасининг ранги) лақабини олди. Икки офат, иккита дахшатли фалокат, миқёсига тенг:«Il y a eu dans le monde autant de pestes que de guerres. Et pourtant pestes et guerres trouvent toujours les gens aussi dépourvus»[4, 40]. - Дунёда урушлар каби вабо эпидемиялари кўп бўлган. Шунга қарамай, вабо хам, уруш хам одамларни доимо хайратда қолдиради (Н.X. 
Турсунова таржимаси). Ушбу икки бахтсизликнинг натижаси бир хил: яқин ва севикли оилаларнинг ажралиши, эркинликни чеклаш, халқларнинг қирилиши, умумий ғазаб қайғу. Муаллиф тез-тез харбий луғатдан фойдаланади: «vie de prisonniers » ("махбуслар хаёти" [4, 77]), «ville menacée» ("шахар хавф остида" [4, 114]), «interminable défaite» (“чексиз мағлубият" [4, 128]). Ушбу талқиндан сўнг, доктор Риэ - бош қахрамон - ва унинг дўстларининг немис истилоси даврида Франциядаги қаршилик харакатини жонлантиришга қаратилган эди.

Вабо - Худонинг жазосими? Ўзининг вазларида, романнинг бош қахрамонларидан бири бўлган рухоний Панлю, Орандаги вазиятни инжил хикояси билан таққослайди: тошқин, Содом ва Гоморранинг вайрон бўлиши, Мисрнинг ўнлаб қатиллари ва Иованинг синовлари: «Depuis le début de toute l'histoire , le fléau de Dieu met à ses pieds les orgueilleux et les aveugles. Méditez cela et tombez à genoux » [4, 98]. Рухоний юқумли касалликни Оллохдан юборилган жазо сифатида қабул қилади: у эпидемиянинг бошида шахарга ёққан “кучли ёмғир” («pluies diluviennes » [4, 36])ни эслайди.

Адабиётлар:

1. Великовский С.И. Грани несчастного сознания. Театр, проза, философская эссеистика, эстетика Альбера Камю. Москва, «Искусство», 1973.

2. Camus A., Essais, Paris, Bibl. de la Pléiade, 1965, p.415.

3. Camus A., Théâtre. Récits. Nouvelles, Paris, Bibl. de la Pléiade, 1962, p.1966.

4. Camus A. La peste. Edition Bélin/Gallimard, 2012. - 351 p.p.

\section{ASSIA DJEBARNING «L'AMOUR, LA FANTASIA» ASARIDA YORITILGAN MAVZU XUSUSIDA}

\section{Yahyoqulova Nigora Shuxratovna Samarqand veterinariya meditsinasi instituti o'qituvchisi}

Annotation: The history of women's literature in Algeria has been studied by many writers. They studied women's literature at all levels, as well as in romantic genres: general and thematic, critical. They also put forward topics that reveal the realities of cultural and social life in Algeria. For these writers, creativity was also a battleground for a closed society that did not stop discriminating against and discriminating against women. We have tried to dwell at least a little in this article on the topics covered in the works of Assia Djebar, one of the most famous women writers in the East and perhaps the first Algerian writer to be known for her intricate style of writing.

Key words : Algerian women's literature, creativity, creative style, "L'Amour, la fantasia".

Assia Djebar - Jazoirning eng sevimli yozuvchilaridan biri va uzoq vaqtdan beri "Shimoliy Afrika adabiyotining eng muhim shaxslaridan biri" sifatida tanilgan. 2015 yil 7fevral kuni Fransiya Akademiyasi Assia Djebarning Parijda vafot etganini e'lon qildi. 1936 yilda Jazoirning Cherchill shahrida tug'ilgan Djebar o'zining yetmish sakkiz yillik umrini Jazoir, Fransiya, Tunis va AQShda yashab, yozuvchi, tarixchi, kino arbobi va professor sifatida o'tkazdi. Garchi Jebarning adabiy asarlari erkaklar hukumronlik qiladigan Islom dunyosidagi ayollarga bag'ishlangan bo'lsa-da, u arab-barbar, musulmoncha va fransuzcha qarashlarni, his-tug'ularni o'z ichiga olgan ko'plab asarlari bilan mashhur. «Figaro» da uning o'limi e'lon qilingan kuni Djebarga hurmat bajo keltirar ekan, prezident Fransua Olland uni quyidagicha ta'riflagan: "cette femme de conviction, aux identités multiples et fertiles qui nourrissaient son œuvre, entre l'Algerie et la France, entre le berbère, l'arabe et le français».

2005 yil iyun oyida Fransiya Akademiyasiga qabul qilingan Djebar fransuzlar tomonidan tan olingan birinchi Shimoliy Afrika ayol yozuvchisi edi. U, shuningdek, 1955 yilda Ecole Normale Supérieure de Sèvresga qabul qilingan birinchi Jazoir talabasi va birinchi musulmon ayol edi. 
Djebar o'z asarlarida Jazoirdagi patriarxal va kolonial tuzumni qoralab yozgan bo'lsada, Jazoirda yashab ijod qiladigan akademiklari tomonidan hurmatga sazovor bo'lib, u bunday hurmatga Jazoir musulmon ayollarining ozodligi hamda colonial tuzum haqida yozganlari orqali erishgan. Djebar, o'zining adabiy ijodi Arab va barbar madaniyatiga asoslanganligini «foi musulmane» («musulmon iymoni»), « langue de souche... la langue berbère» («ona tili ... Barbar tili ») ekanligini takidlasada, shuning bilan birga oltmish yil davomida fransuz mustamlakasi hukmronligi davrida erishgan yutuqlari haqida to'xtalar ekan va aynan nima uchun fransuz tilida yozishini shu orqali izohlashga harakat qiladi. Aslida, Djebarning ko'plab asarlari uning tilga bo'lgan munosabati bilan bog'liq, chunki u Jazoirda so'zlashiladigan tillar, xususan fransuz, arab va Barbar tillari uning shaxsan o'zi uchun qanday ahamiyatga ega ekanligini aytib o'tadi.

Jazoir adabiyoti nafaqat Fransiya mustamlakachiligi zulmni emas, balki hozirga qadar shakllanmagan va tartibga solinmagan mafkuraviy bo'shliqlarning mustaqilligi uchun kurashni ham tasvirlaydi; shuning bilan birga, Assiya Djebar asarlari asrlar davomida Jazoirda ayollar ongini mavjud bo'lgan ijtimoiy tuzum g'oyalaridan ham ozod qilishga urinishining ideal taqdimotidir. Djebar o'zining birinchi « La Soif » (1957) romanini nashr etgandan so'ng ketma - ket bir nechta asarlarni , "Les impatients" (1958), "Les Enfants du Nouveau Monde» (1962), "Les Alouettes Naives" (1967), "La Nouba des Femmes du mont Chenoua» (1977), va «Femmes d'Alger dans leur Appartement» (1980) kabilarni nashr ettirdi. Biroq, 1960 yillarning oxiriga kelib u sotsiologik nuqtai nazardan o'z vatandosh ayollari bilan uchrasha olmadi va ijodda chekinish qilishga qaror qildi.

Islom mamlakati bo'lgan Jazoirda, ayollar erkaklarga qaraganda kam savodli; bosib olingan mamlakat mustamlakachi mamlakat tilida so'zlashishi ehtimoli esa kam. [ 2. 206223bb;208.] Shunday qilib, Djebarning asarlari to'laligicha u istagan o'quvchi auditoriyasi (chegaralangan Jazoir ayollari) ga yetib bormadi. Djebar ijod qilmagan ushbu «sokin o'n yil»» davomida, u mamlakat bo'ylab sayohat qildi va Jazoir ayollaridan og'zaki dalillar to'pladi. Ushbu dalillar uning eng murakkab asari - «L'Amour, la fantasia» asarinining yaratilishi uchun material bo'ldi. Ushbu roman Djebarning Jazoir ayollari hayot yo'li tarixini qay darajada yorita olganligini, va bu jarayonda uning ste'dodi turli manbalarda o'rganilgan. Uning tarixiy tayyorgarligi asarda sezilarli edi, shu bilan $\mathrm{u}$ fransuz arxividan olingan ma'lumotlardan foydalanib, mustamlaka qilingan mamlakatda ayollarning ovozlarini eshitish uchun ayollar kurashiga dalil sifatida og'zaki hikoyalarni hujjatlashtirdi. Djebarning asari ayollarni Jazoir tarixidan chetlatish muammosini hal qilishga urinish sifatida qaraladi, $u$ ozod qilingan, savodsiz Jazoir ayollari uchun qarshi xotira yaratishga ijodini o'z xotiralariga topshiradi.[ 4. 1-10;10 b.] Bundan tashqari, "L'Amour, la fantasia» da zo'ravonlik urushidan keyingi ayollarning sukunatiga barham berish muammosiga oydinlik kiritib, milliy va tarixiy munozarada ayollar o'rnini tan olishga intiladi.

"L'Amour, la fantasia» da zamonaviy Jazoir ayollarining o'zlari uchun ikon yaratishda olib borgan kurashini o'rganish, bunda ular erkaklar bilan bog'liq bo'lmagan holda o'z o'rinlarini i belgilashga intilishi, shuningdek Jazoir tarixidagi ayollarning rolini tushunish istagini aks ettiradi, Djebar ayolning sukutini tanqid qiladi va shuu orqali u ularni jonlantirishga harakat qiladi. [7b] Uning romanida zamonaviy dunyoga ko'chib o'tgan Jazoir ayollari va jismoniy hamda ruhiy jihatdan izolyatsiya qilingan boshqa ayollar tasvirlangan. Uning asarlarida islomning dastlabki davrida yashagan taniqli ayollarning hayotidan aniq voqealar haqida ko'p fikr yuritiladi. Biroq, u «La fantasia» da Jazoir Mustaqillik urushini tasvirlar ekan, u o'sha davrdagi oddiy ayollarning hikoyalarida ularning tajribasiga ham e'tibor berishga harakat qiladi. «La fantasia» da ayollarga tarixda ijtimoiy va qonuniy ravishda rad etilgan, mustamlaka sharoitida bo'ladimi yoki yangi mustaqil Jazoirda ham ovoz va o'rin berishga qaratilgan. Muallif Jazoir ayollarining zulm va qarshilikni, ozodlikka bo'lgan kurashni yanada yorqin tsvirlash uchun ularning o'zlari so'zlab bergan hikoyalarni to'liqroq o'rganib chiqishga . Inqilobiy urushda aynan mana shu ayollar ham jangchilar, hamshiralar, 
jangchilarning vafodor xotinlari ularning ko'makchilari yoki qurbonlar sifatida katta rol o'ynaganliklariga qaramay; mustaqillikdan keyin ham ularning jamiyatdagi roli haliham chegaralanganligiga e'tibor qaratadi. Jazoir tarixi Assia Djebarning feministik qarqshlari orqali tasvirlanadi, tasvirda Jazoirni go'yoki mag'rurligi va tarixdan mahrum bo'lgan kelin sifatida tasvirlanadi va bu ayoli ham patriarxal tuzumga bo'ysunadi, bu esa uni tabiiy huquqlaridan foydalanishga imkon bermaydi.

Assia Djebar ayollarning holati va Jazoir tarixiga qo'shgan hissini tasvirlash bilan bir qatorda, Fransiyaning Jazoirni bosib olishini tarixiy ham yoritadi. Tarixchi sifatida ish olib borgan Djebar Fransiya arxivida rasmiy hujjatlar va askarlarning o'z oilalariga yuborgan xatlaridan o'ttiz ikkita harbiy hujjatlarni topadi. Ushbu fransuz askarlarining hikoyalari Djebar tomonidan Jazoir tarixini qayta ko'rib chiqish va qayta tiklash uchun ishlatilgan. Djebar Jazoirni Dey shaxsiy daxlsizlik va Jazoir dinini hurmat qilishni kafolatlovchi shartnoma imzolash bilan taslim bo'lishga majbur bo'lgan «ochiq shahar» deb ta'riflayd. Ammo bu shartnoma qog'ozdagi siyohdan boshqa narsa emas edi. "Ochiq shahar»da 1831 yil fevralgacha to'rt mingdan ortiq fransuz fuqarolari istiqomat qilgan. Ushbu "g'ayratli kelgindilar» bosib olingan shaharni qiynoqqa solishni juda xush ko'rishardi. «La capitale est vendue: le prix de son trésor légendaire, l'or d'Alger expédié par une caisse à la France [...] Alger, dépouillé de son passé et de sa fierté.» [8.7b]. Bundan tashqari Djebar o'n to'qqizinchi asrda yuz bergan fojiali voqealar haqida hikoya qiladi. U, shuningdek, Fransiya armiyasining taslim bo'lishni va g'orlarga chekinishni rad etgan Uled Ria qabilasiga qilgan shafqatsizligini qoralaydi. Jazoirni baland ruhi bilan bo'ysundirish bo'yicha muvaffaqiyatsiz muzokaralardan so'ng frantsuz armiyasi erkaklar, ayollar va bolalarni tutun chiqarish uchun g'orlarni yoqib yuboradi.[6.12 b.]. Fransiya istilosi davrida Jazoir azoblarini tasvirlaydigan sahnalar juda ko'p, ammo Djebar e'tiborni ko'proq jasur sherlar sifatida tasvirlangan Jazoir ayollariga qaratadi. U askarning yuragini yirtib tashlagan yoki o'z bolasini tirik asirlikka qoldirmasdan qurbon qilishni tanlagan ayol misolini keltiradi.[5. 301-311bb;] Ushbu olijanob va fojiali hayot kechirgan shaxslar qilgan qurbonliklar faqat Djebar qalami orqali to'liq ifodalab berilishi mumkin edi. Bundan tashqari, Fransiya hukumati Jazoirni boshqarish uchun zo'ravonlikdan ko'proq foydalangan; ular mahalliy madaniyatni yo'q qilish va uni fransuzcha bilan almashtirish kabi turli xil strategiyalardan foydalangan. Madaniyatsiz millat mavjud bo'lmaganidek ular millat madaniyatini yo'q qilishga urunishadi, shuningdek fransuz maktablarini qurish va boshqaruvda arab tilidan foydalanishni taqiqlash Jazoir madaniyatiga qarshi jiddiy urinishlar bo'lgan. Djebarning tarixni o'rganib chiqishi unga tarixiy faktlarga ayol nuqtai nazari bilan yondashishga imkon berib, Jazoirliklar, xususan, tarixda jangchilar sifatida qayd etilish huquqidan mahrum bo'lgan ayollar va jabrdiydalarning azoblanishini yoritib berdi.

Shunday qilib, 1985 yilda chiqarilgan «L'Amour, la fantasia» avtobiografik va shuning bilan bir qatorda Jazoir ayollarinig Jazoirni bosib olinishi og'zaki hikoyalarini mohirlik bilan birlashtirilishidan vujudga kelgan ajoyib asar desak yanglishmagan bo'lamiz. Va shuning bilan bir qatorda ushbu romanda o'z o'rnini jamiyatda, oilada topishga intilgan ozodlik uchun qo'rqmasdan kurashgan jasur Jazoir ayollari timsoli tasvirlanadi. Ushbu maqolamiz « La fantasia» ning Jazoir ayollari harakati tarixini to'g'ri ochib berish, inqilobiy urushda shafqatsiz ishtirokini yoritib berishni o'rganishga qaratilgan.

\section{Adabiyotlar :}

1. Assia DjebarL'amour, la fantasia: roman. Front Cover.. A. Michel, 1995 - Fiction - 316 pages

2. Clarisse Zimra, "In Her Own Write: The Circular Structures of Linguistic Alienation in Assia Djebar"s Early Novels," Research in African Literatures, Vol. 11, No. 2, (Summer, 1980), pp.206223; p. 208.

3. Jane Hiddelston, Assia Djebar Out of Algeria (Liverpool: Liverpool university press, 2006, p. 7.

4. Mary Stevens, "The Light in The Heart: Cultural capital versus cultural memory in Assia Djebar"s epigraphs," Francophone post-colonial studies, Vol. 3, No. 2, (autumn/Winter, 2005), pp.1-10; p.10. 
5. Mildred Mortimer, "Language and Space In The Fiction of Assia Djebar And Leila Sebbar," Research in African literature, Vol.19, No.3, (autumn, 1988) ,pp.301-311;p.303.

6. Sanne Boersma, The Powerful Writing Strategies of Assia Djebar and Toni Morrison Differentiation of The Depiction of Otherness through Literature (Utrecht: Utrecht University, 2010), p.12.

7. Yaxyoqulova Nigora Shuhratovna «Ассия Джебар - многогранная алжирская писательница» “ORIENTAL ART AND CULTURE” НАУЧНО-MЕTОДИЧЕСКИЙ ЖУРНАЛ n¹2 26 марта 2020 г c.100-104

8. Yahyoqulova N. Sh «The main trends in the literary process in France in the second half of the 20th century» JournalNX- A Multidisciplinary Peer Reviewed Journal ISSN No: 2581 - 4230 VOLUME 6, ISSUE 4, Apr. -2020

9. Yakhokulova N. Sh. «Algerian post-colonial literature» «RESULTS OF MODERN RESEARCH AND DEVELOPMENT-2020» Part - 1, 27th of April, 2020, p.87-92

10. https://press.umsida.ac.id/index.php/icecrs/article/view/563/439

11. https://press.umsida.ac.id/index.php/acopen/article/view/404/265

\section{L'USAGE DU ROMAN FLAUBERTIEN DANS DES CAMPAGNES CITY BRANDING}

\section{Negmatov Nodir \\ Professeur de l'institut des \\ langues etrangeres de Samarcande \\ E-mail:negmatov@samdchti.uz}

Annotation: In this novel we will analyze the influence and relation of Gustav Flaubert's novel "Madame Bovary" with city branding. In addition, we will compare the text of the novel with the text of the tourist program where the novel was applied.

Key words : city branding, Madame Bovary, festival, Normandy, village, Ry, Yonville-l'Abbaye.

L'œuvre de Flaubert Madame Bovary est devenu un des grands symboles de la culture littéraire française. L'écrivain réaliste a toujours cherché reproduire dans son roman tous les facettes où il avait vécu. Il a exploré la diversité de milieu social normand qui a décrit et a composé les relations entre les individus. Dans le roman Madame Bovary, le lecteur a sous ses yeux la société française et surtout cauchoise du milieu du XIXème siècle dans toute la diversité. Dans le monde provinciale normande qui a servi de toile de fond à l'intrigue a présenté des petits bourgeois, paysannes aisés, paysans miséreux, pauvres, boutiquier et hobereaux. La relation de l'intrigue est du tissue social, qui donne l'illusion de la réalité.

Chaque année au village Ry se déroule au mois d'avril, le festival ${ }^{1}$ dédié à l'œuvre de Gustave Flaubert Madame Bovary. Flaubert ayant vécu et grandi en Normandie, après quelques temps lui est arrivé l'inspiration d'écrire son fameux roman, il était dédié au fait divers normands: le suicide de Delphine Delamare, épouse d'un médecin qui est mort après quelque temps. Cette histoire est passée au village de Ry, au Seine-Maritime. D’après cette histoire dans ce village, chaque année la mairie organise le festival consacré à Madame Bovary. Ce festival donne la possibilité découvrir plus profondément les traces de Madame Bovary. Ce festival est un parcours littéraire qui retrace plusieurs lieux qui étaient inspiré Flaubert. Dans le village Ry il y a les installations qui repassent les principales scènes du roman. Les panneaux ${ }^{2}$ avec QR code, grâce à quoi nous pouvons écouter des grands items du roman relier aux lieux avec le smartphone. Les panneaux interactifs sont consultables toute l'année, mais l'office de tourisme nous donne la possibilité d'aller plus loin, grâce au festival de Bovary. Cette année il va durer deux jours, le 27 et 28 avril, sous forme d'un jeu avec une exposition, quiz et le diner au style de bovarysme. Le premier jour ils ont organisé le mariage à l'église de Ry :

"La mairie se trouvant à une demi-lieue de la ferme, on s'y rendit à pied, et l'on revint de même, une fois la cérémonie faite à l'église. » 
Pendant tous les deux jours ils nous proposent une visite guidée à Ry sur les pas de Madame Bovary, où font des arrêts sur les sept lieux dont un des lieux c'est l'église de Saint-Sulpice où le mariage est passé à Ry qui porte le nom dans le roman Yonville-d'Abbaye où Charles et Emma ont donné le serrement l'un à l'autre :

"Réputé être le "Yonville l'Abbaye" du roman à scandale "Madame Bovary", Ry doit sa notoriété à Gustave Flaubert qui parle de la grande rue "longue d'une portée de fusil et bordée de quelques boutiques". »

C'est une église qui a connu beaucoup d'aménagement successifs. La tour centrale est daté de XIIe siècle, il y a le porche qui était destiné à protéger l'accès principal de l'église. Au sud se trouve la Chapelle de la Vierge dont Flaubert parle : "Et brusquement elle retira sa main, pour entrer dans la chapelle de la Vierge, où, s'agenouillant contre une chaise, elle se mit en prière. ". [3] Cette chapelle a un bel ensemble poinçons avec rageurs et d'entraits qui est finement réalisé. Nous pouvons aussi admirer la statue qui est en bois de Notre Dame de Ry. Elle est comme l'empreinte de la tristesse et de la douceur. Cette chapelle a été faite au début de XVIIIe siècle. La cathédrale curiale a un long mur qui constitue à un beau travail fait au XIXe siècle dans le style néo-gothique. [3]

"L'édifice qui porte le nom du saint patron du village a connu des aménagements successifs du XIIème au XIXème siècle. La tour centrale, d'époque romane est la partie la plus ancienne du monument. La flèche date quant à elle du XIXème siècle, la précédente ayant été détruite par un incendie. La majorité des aménagements a été effectuée au XVIème siècle, dont le porche en bois sculpté, classé Monument Historique, est sans conteste l'élément le plus remarquable. Abritant l'entrée de l'église, le porche aurait été commandité par un seigneur de la famille de Moy" [4]

C'est un des lieux proposé dans le programme sur les pas de Madame Bovary. L'office de tourisme donne une petite description de cette église en faisant la référence au texte de Flaubert, surtout le moment de mariage.

Dans le programme la visite commence par la grande rue. Flaubert a indiqué que cette rue est une seule grande rue où il y a quelques boutiques, mais dans le programme il nous donne une description de cette rue d'aujourd'hui :

$\begin{array}{cc}\begin{array}{c}\text { Flaubert: Madame } \\ \text { Bovary }\end{array} & \text { Ry: programme touristique } \\ \text { «La rue (la seule), } & \text { "Le long de la Grand' Rue se trouvent les commerces et les } \\ \text { longue d'une portée } & \text { maisons de caractère qui font le charme de Ry : colombages, } \\ \text { de fusil et bordée de } & \text { pans de bois, briques. Bourg marchand, Ry a toujours été un } \\ \text { quelques boutiques } & \text { lieu de ravitaillement pour les communs alentours et } \\ \text { s'arrête court au } & \text { comptait de nombreuses boutiques, hôtels et cafés. Le village } \\ \text { tournant de la } & \text { a su garder le charme intemporel des commerces d'antan tels } \\ \text { route» } & \text { que le barbier, la droguerie ou encore l'horlogerie. » }\end{array}$

Dans le programme touristique, nous voyons le changement dans le texte de programme par rapport avec le texte du roman. Il nous semble que les nombre des boutiques ont significativement augmenté, car dans le texte du roman il est noté qu'il avait bordée de quelques boutiques ${ }^{1}$, par contre dans le texte du programme il nous donne une information qu'il avait nombreuses boutiques, hôtels et cafés ${ }^{2}$ dont la perception se change concernant cette rue. 
En passant juste à côté de la maison du XVe siècle ${ }^{1}$, nous arrivons aux halles et la mairie qui garde un style de la moitié du XIXe siècle. En faisant la description, Flaubert nous donne une idée sur les halles, ainsi que la mairie, qui occupent la moitié de la place de Ry. De plus Flaubert compare la mairie avec le style de l'architecture parisienne avec le temple grec qui est juste à côté de la maison du pharmacien dont dans le programme noté comme la maison du XVe siècle, qui est orné en bois avec un rez-de-chaussée ouvert à la circulation. Une description des halles et de la maire est plus détaillé par rapport au texte du roman :

Flaubert: Madame Bovary

Ry: programme touristique

"Les halles, c'est-à-dire un toit de tuiles supporté par une vingtaine de poteaux, occupent à elles seules la moitié environ de la grande place d'Yonville. La mairie, construite sur les dessins d'un architecte de Paris, est une manière de temple grec qui fait l'angle, à côté de la maison du pharmacien.»
"Ce bâtiment quadrangulaire construit en 1855 abrite la mairie et les halles du marché. Couronné d'un fronton central, l'étage est surmonté d'un dôme couvert d'ardoises abritant une horloge, à la mode des grands hôtels de ville. Sous les halles ouvertes, le marché de Ry était le plus important du canton de Darnétal jusqu'au XIXème siècle. Elles accueillent encore aujourd'hui le marché le samedi matin. Sous la verrière, une structure métallique permettait aux pompiers de faire sécher leurs tuyaux en lin. »

Une notice essentielle, c'est ce que sous les halles qui se trouve sur la place de Ry ou comment di Flaubert, Yonville il y a le marché qui est le plus important du canton à l'époque de Flaubert. En s'avançant vers nord, vers la rue de l'église, nous arrivons à l'ancien Presbytère qui date du XIIIème siècle.

«...et, après avoir prié madame Lefrançois de le lui faire remettre au presbytère dans la soirée, il sortit pour se rendre à l'église, où l'on sonnait l'Angelus. (...) En effet, la porte du presbytère grinça, l'abbé Bournisien parut »

Ce bâtiment à une inscription en brique verbissée noire sur le côté de l'édifice ${ }^{2}$, il note le nom du maitre d'œuvre Aubin Barq et il date du 1742. Cette presbytère est juste à côté de l'église où a eu lieu le mariage d'Emma et Charles Bovary. En descendant vers le chemin vers $^{3}$ nous s'approchons à la ferme du Bourg :

"La dernière ferme du bourg cessa son activité en 1995. Des chantiers de réinsertion réhabilitèrent les différents bâtiments qui la composaient aux XVIIIème et XIXème siècles : étable, écuries, grange à foin et à blé. Restaurés, ces bâtiments offrent une belle vue d'ensemble sur tous les matériaux utilisés en Normandie : pierre, silex, brique, torchis et pan de bois. "

Nous allons vous montrer maintenant l'itinéraire de Charles, quand il arrive pour la première fois aux Bertaux

"Ce qui amène Charles à revenir encore une fois sur ses pas. Les Bertaux doivent être situés dans le voisinage de Saint-Victor plutôt que de Vassonville, parce que le soir des noces d'Emma, le père de Charles envoie acheter des cigares à Saint-Victor. Il est probable que Flaubert se soit inspiré, en partie, de la ferme que ses parents possédaient à SaintMaclou-de-Folleville, à une demi-lieue de Saint-Victor (la demi-lieue qui sépare les Bertaux de la mairie ?). »

Ici à la ferme Emma est passé son enfance, nous notons que Flaubert a été inspiré car sa famille avait la ferme qui ne se situait pas trop loin. Dans ce ferme, qui ne fonctionne pas 
désormais, nous donne la possibilité des matériaux qui ont été utilisés. E le dernier lieu à visiter c'est le Phalanstère. C'est un bâtiment du XIXe siècle qui désigne un ensemble de bâtiments communautaires qui sont destinés à créer une organisation sociale.

Pendant de ces deux jours il sera organisé le jeu sous forme du quiz, tous les vitrines seront décorées avec les questions qui va permettre de gagner des petits prix. Ces prix seront remis pendant la fête des voisins le 25 mai.

La pièce théâtrale organisée pendant le deuxième jour du festival, jouée à Avignon qui porte le nom Emma Bovary ${ }^{1}$. Adaptation du roman aux pièces théâtrales ont une grande importance pour la promotion et présentation de l'écrivain, de son œuvre et de city et country branding. La première tentative de l'adaptation du roman flaubertien a été fait par George Taylor, avant de 1888 qui était infructueuse. Et ensuite à partir 1936 jusqu'à 2018 a été fait les adaptations théâtrales de Madame Bovary. Mais aussi il y avait quelques adaptations aux ballets : le premier est en 1996 par Jaques Cesbron, Madame Bovary², sur une musique de Don Freund, à l'université d'Indiana, aux États-Unis, deux autres adaptations de Michael Shanonn : Madame Bovary - one actballet de 1996 et Madame Bovary Pas de deux de 2007. Tous les deux ont été présentés aux Etats-Unis. Et l'autre de François Mauduit qui était créé en 2008 au XXe théâtre de Paris : Madame Bovary, sur les Quatre derniers lieder de Strauss ${ }^{3}$. Si nous regardons les pièces théâtrales, parmi eux, deux adaptations, celle qui a faite à Berlin et l'autre à Moscou ont eu le plus grand succès.

"C'est le 19 février 2011 que la première de Madame Bovary est jouée au Théâtre Maxime Gorki de Berlin, avec un succès certain. Cette Madame Bovary, jouée ensuite dans plusieurs villes (Hanovre, Ludwigshafen), est aujourd'hui reprise pour sept représentations au Théâtre d'Heilbronn, du 8 novembre au 28 décembre 2104. »

C'était une adaptation libre avec de la perspective féministe, qui représente les personnages de Flaubert dans le temps moderne, au mode contemporaine. L'auteur est Tina Rahel Völcker ${ }^{4}$ a fait une sorte de tragédie semi-musicale et féministe, dont le personnage Lheureux a changé de sexe pour devenir Lheureuse, pour donner à ce personnage une sorte de proximité physique corruptrice avec Emma. Par contre le spectacle Bovary 5 au théâtre Vakhtangov à Moscou qui avait aussi un grand succès, était faite par Olga Soubbotina, qui a choisi dans le roman les phrases et les scène les plus significatives. Le spectacle a été fait en deux actes qui est très original et subtil. Il y a l'intégration des événements autobiographiques de la vie de Gustave Flaubert, qui est vraiment important pour avoir l'information sur la préhistoire du roman. Dans le premier temps sur la scène il y a un seul personnage, l'écrivain en personne, qui a prononcé la célèbre phrase "Madame Bovary, c'est moi. "6, ensuite le procès du spectacle continue pour atteindre à la religion et à la morale et l'ordre sociale, donc les spectateurs se transforment en participants du procès, avec Flaubert, l'avocat Senard et le procureur Pinard. Mais le deuxième acte, le metteur en scène a réalisé pour le public un voyage dans le monde de la bourgeoisie française du début du XIXe siècle en France. Ce spectacle comme une guidée dans le passé, pour cela les événements ont été déplacé d'une salle à l'autre en créant l'atmosphère maximum vraisemblable de la Normandie. C'est un spectacle tragique et comique en même temps qui donne l'ambiguïté des émotions.

C'est une brochure sur le programme à Ry, Sur les pas de Madame Bovary qui est était pratiqué pendant le festival. Il porte une brève information sur les lieux à visiter avec la carte pour simplifier le chemin touristique. 
Un autre festival de Madame Bovary a été organisé près du lac de Lugano, pour célébrer et rendre l'hommage à l'héroïne passionnante de Flaubert. De 24 à 28 octobre 2018. Pendant ce festival Madame Bovary est le fil conducteur de la huitième édition de la revue littéraire Piazza Parola ${ }^{1}$, dont le lac de Lugano a devenu le lieu de rencontre qui sont amoureux à la culture flaubertienne. La protagoniste de Gustave Flaubert était au centre de toute l'exposition qui était ouvert pendant la cérémonie inaugurale intitulée "Madame Bovary nella letteratura, nella pittura e nella musica $»^{2}$, qui a présenté la figure de l'héroïne romantique par excellence dans une édition organisée par la société Dante Alighieri de la Suisse italienne et du Lac Lugano Art and Culture qui s'adresse aux écrivains, aux éditeurs, aux journalistes, aux essayistes, aux poètes et aux historiens, aux femmes qui lisent.

"Quanto a Emma, evitava di domandarsi se lo amasse. Era convinta che l'amore dovesse arrivare di colpo, accompagnato da luci e fragori, simile a un uragano celeste che piomba sulla vita, la sconvolge, travolgendo la volontà come foglie secche, e trascina ogni sentimento nell'abisso. Non sapeva che la pioggia a goccia a goccia crea laghetti sulle terrazze delle case, quando le grondaie sono otturate, e avrebbe continuato a credersi al sicuro se d'improvviso non avesse scoperto una falla nelle sue difese ».

Ces lignes a été écrites par Flaubert dans son célèbre roman. Ce festival commence par une soirée consacrée au rôle de la femme au XIXe siècle, en racontant leurs désirs et leurs passions au cours d'un siècle.

Tous les jours les sous thèmes pendant le festival qui explorent différents aspects d'être une femme, un lecteur et une écrivaine était développés.

Rouen a été mentionné maint fois dans les romans du différentes époques : chez Stendhal, Mémoires d'un touriste, 1838, Guy De Maupassant, Le Horla, 1886, Annie Duperey, Les chats de hasard, 1999, Gustave Flaubert, Madame Bovary, 1857 et etc.

"On entendait le ronflement des fonderies avec le carillon clair des églises qui se dressaient dans la brume. Les arbres des boulevards, sans feuilles, faisaient des broussailles violettes au milieu des maisons, et les toits, tout reluisants de pluie, miroitaient inégalement, selon la hauteur des quartiers. Parfois un coup de vent emportait les nuages vers la côte Sainte-Catherine, comme des flots aériens qui se brisaient en silence contre une falaise. "

Flaubert a présenté avec un grand amour Rouen. Il y a plusieurs variantes des programmes touristiques, qui présente la vie de Flaubert et ses romans, surtout Madame Bovary. Un des programmes touristiques qui nous amène au passé, à l'époque de Flaubert, s'appelle «Sur les pas de Gustave Flaubert „ ${ }^{3}$ parle sur sa vie et ses œuvres : Salambô, L'Éducation Sentimentale, La Tentation de Saint-Antoine, Bouvard et Pecuchet, mais surtout Madame Bovary. Ce programme dure quatre jours et nous ramène aux lieux vécus par Flaubert et mentionnés dans ses romans. Mais nous allons parler sur la cathédrale de Rouen dont Flaubert a présenté dans une manière intéressante.

"Promenez-vous dans les ruelles très animées de Rouen et visitez la cathédrale. Arrêtezvous devant le vitrail de Saint Julien l'Hospitalier (13ème siècle), dans le déambulatoire. $»^{4}$

Cette promenade ouvre une nouvelle vision sur la cathédrale de Rouen, c'est une vision flaubertienne. Il présente la cathédrale en tous les détails. Du côté de la réalité, Flaubert a fait peu de mention de la cathédrale dans sa correspondance, mais dans Madame Bovary, si nous allons parler le côté de la fiction, quand Léon et Emma se sont donné rendez-vous dans la cathédrale, c'est une scène étonnante qui a marqué le début de leurs rencontres à Rouen.

Bibliographie: 
1. Albert Cassagne, (1959) La théorie de l'art pour l'art en France, chez les derniers romantiques et les premiers réalistes, Paris, L. Dorbon : Genève.

2. Eshuis, J., Klijn, E.-H., \& Braun, E., (2014), Marketing territorial et participation citoyenne : le branding, un moyen de faire face à la dimension émotionnelle de l'élaboration des politiques ? Paris : Revue Internationale des Sciences Administratives.

3. Gustave Flaubert, (1921), Madame Bovary, mœurs de province, en CEuvres complètes illustrées de Gustave Flaubert, illustrations de Pierre Laprade, Paris : édition du Centenaire.

4. Gustave Flaubert, (1927) Madame Bovary, Mœurs de province, illustrations de Pierre Rousseau, Henri Cyral éditeur, Paris.

5. Chebat Jean-Charles, Hénault Georges M. L'efficacité de l'image publicitaire. In: Communication et langages, $\quad n^{\circ} 22, \quad 1974 . \quad$ pp. 107-117. https://www.persee.fr/doc/colan 033615001974 num 2214106 consulté le 07.05.19

6. Colletis, Gabriel et Bernard Pecqueur, 2005, «Révélation de ressources spécifiques et coordination située», Économie et Institutions, nos 6-7, p. 51-74, http://journals.openedition.org/ei/900

7. Delphine Jayot, " Le bovarysme, histoire et interprétation d'une pathologie littéraire à l'âge moderne », Flaubert [En ligne], Résumés de thèses, mis en ligne le 14 février 2009, consulté le 01 mai 2019. URL : http://journals.openedition.org/flaubert/411

\section{СПЕЦИФИКА «ФРАНЦУЗСКОЙ ЖЕНСКОЙ ПРОЗЫ» ВТОРОЙ ПОЛОВИНЫ ХХ И НАЧАЛА ХХІ ВЕКОВ}

\section{Холбекова Умида Мухаммадовна} Преподаватель СамГИИЯ

Annotation: This article is devoted to the issue of gender stereotypes in literary texts of French women writers of the second half of XX and beginning of XXI. The author examines the evolution of the issue of "French female prose", the socio-cultural reasons for this process and its representation in literature.
Key words : literature studies, feminism, gender issues, French literature, female prose.

Модернизация жизни и отстаивание прав женщин привели к тому, что традиционные место и роль женщин в обществе стали рушиться. В 50-60-е годы прошлого века вопрос социальной дискриминации женщин, перевода женщины из маргинального положения в центральное как в общественно-экономическом, так и в семейно-бытовом плане стало первостепенной задачей феминизма.

Несмотря на то, что этот феномен наблюдается уже в античной Греции, а точнее, в классический период афинской демократии, философских идеях Сократа, поэзии Сафо, трагедии Еврипида «Медея», терминологическое понятие «феминизм» регулярно стало использоваться только в XX веке. В это же время в гуманитарных науках появилось понятие «гендер». В литературоведении исследуются такие вопросы, как специфика «женской литературы», вопросы гендерных стереотипов в литературных текстах, а также сюжеты произведений, где действие сконцентрировано вокруг проблемы поиска собственной гендерной идентичности.

Литературный феминизм активно формировался во Франции. А потому самую долгую и самую яркую литературную историю имеет «французская женская проза». Особенно выделяются имена Жермены де Сталь, Жорж Санд, Эльзы Триоле, Маргарет Юрсенар, Симоны де Бовуар, Франсузы Саган. Сегодня традиции этих ярких звёзд французской литературы продолжают Ирэн Фрэн, Амели Нотомб, Анна Гавальда.

Выход в 1949 году книги Симоны де Бовуар «Второй пол» стал важнейшим переломным моментом истории феминизма. Именно Бовуар, придала женскому вопросу подлинно гендерный характер. «Второй пол» впервые поднял проблему эмансипации женщин глобально, охватывая историю, мифологию, культуру. Труд Симоны де Бовуар относится к периоду «второй волны» феминизма, когда после 
движения суфражисток за избирательное право стали актуальными и другие проблемы женщины в социуме. Писательница сделала акцент на проблеме мужского доминирования в структуре власти, на личном выборе современной женщиной ее жизненного поведения. Ей было необходимо подчеркнуть общность человеческой природы, разрушить миф о «женском уделе». А потому очень часто феминизм Бовуар называют «личностным». Основной тезис книги «Второй пол» [1]: «Женщиной не рождаются, ею становятся». Тем самым Симона де Бовуар утверждает, что не существует такого явления, как женская природа и женственность. Эти понятия, утверждает автор, обусловлены культурно и исторически.

«Только ее поведение, ее качества, все, в чем ее обвиняют, не предопределено ей природой, ее женскими гормонами, и не заложено в клетках ее мозга: общество, общественное устройство, принуждает женщину вырабатывать в себе определенные качества и диктует ей формы поведения, которые предопределены ее “ситуацией” [1, c. 674]. Симона де Бовуар подробно описывает, каким образом конструируется неравенство полов в процессе социализации детей через взаимодействие с родителями и другими взрослыми.

«Родители и воспитатели, книги и сказки, женщины и мужчины всячески расхваливают девочке прелести пассивности, ее учат наслаждаться ими с раннего детства <...> Перед мальчиком, будь он честолюбивым, легкомысленным или робким, будущее открывает множество дорог: он может стать моряком или инженером, остаться в деревне или уехать в город, отправиться в путешествие или разбогатеть. Глядя в будущее, где его ждут разнообразные возможности, он чувствует себя свободным. Девочка выйдет замуж, станет матерью, бабушкой, она будет заниматься домашним хозяйством точно так же, как ее мать, будет воспитывать детей, как воспитывали ее самое. В двенадцать лет она уже точно знает, что ей уготовано, она будет жить день за днем, но строить свою жизнь, ей не дано» [1, с. 339].

Таким образом, источником социального подавления женщины Бовуар видит во внушении обществу идеи о том, что биологическая половая принадлежность - это судьба, что женщина обречена на инертность, на неизбежное репродуцирование, а не изменение, как мужчина.

Реальное освобождение женщины без экономической независимости невозможно утверждает автор.

«Один только труд может гарантировать ей реальную свободу. Как только женщина перестает вести паразитический образ жизни, система, основанная на ее зависимости, рушится, исчезает необходимость в посреднике-мужчине, который связывает ее с внешним миром. Проклятие, тяготеющее над зависимой женщиной, заключается в том, что ей не дозволено делать что-либо самой» [1, с. 759].

Ещё один аспект «Второго пола» заключается в том, что стремясь заставить мужчин признать равенство с ними женщин, Бовуар не предполагала тождества полов, при том, что утверждала необходимость для женщин стать такими же умными, как и мужчины. Тем самым она выступила против тех, кто, полагал, что женский разум более слаб, чем мужской, и, стало быть, считал закономерным подчиненное положение женщин в общественной жизни.

Ещё одной популярной представительницей феминистской женской прозы является Франсуаза Саган, которая признана основателем нового типа художественного мышления.

«Франсуаза Саган - одна из немногих писательниц, способных столь мастерски передать глубину и непредсказуемость женского чувства. Ее героини - женщины сильные и независимые, они ломают правила ради своих избранников, но в то же время сильно зависят от обстоятельств и своих чувств. Именно это противоречие и отличает женщину XX века, непредсказуемую, глубокую и думающую, женщину, 
которая отказывается подчиняться мужчине, но не может найти свой собственный путь» [2, с. 127].

Точный психологический рисунок Франсуазы Саган раскрывает её героинь любящих и любимых, но одновременно одиноких и неудовлетворенных жизнью. Им всё ещё трудно найти свой собственный путь. Так главная героиня романа «Любите ли вы Брамса?» [3] Поль материально независима от мужчин, когда-то она отказалась от брака, не приносящего ей счастья. Тридцатидевятилетняя героиня Ф.Саган, гордится свободой, независимостью, любимой работой. На первый взгляд, кажется, что у Поль есть все то, к чему так стремились феминистки XX века. Но Поль тяготится своей свободой и независимостью в любовных отношениях, она хочет стабильности, законности той любви, которую испытывает к своему мужчине Роже.

В молодости слова «свобода» и «независимость» у героини приравнивались к слову «счастье». Сейчас, когда ей тридцать девять лет, Поль не хватает того, от чего она когда-то отказалась. «Потом я, наверное, я бы так и жила: со временем стала бы, не задумываясь изменять Марку... не знаю... Знаю, что у меня был бы ребенок... И только ради этого...на замолчала <... В двадцать лет все было иначе. Сейчас она уже не пыталась взять, она пыталась лишь сохранить. Сохранить профессию и мужчину, и, несмотря на свои тридцать девять лет, она ни в чем не была уверена» [3, с. 85]. Свобода для главной героини - одиночество.

Таким образом, писательницы-феминистки «второй волны» продолжая бороться за независимость и свободу женщины, наряду с вопросами социальной дискриминацией, поднимали вопросы семейной и интимной жизни.

Установки феминисток о семье и браке, о свободе межличностных отношений, свободе профессиональной ориентации легли в основу данного романа, где героиня независима экономически, может сама обеспечить себе существование. Писательница, следуя феминистическим доктринам о равноправии отношений между полами, предоставляет своей героине выбор. Поль выбирает путь любви, но любви «зависимой» от ее мужчины. Роже по-прежнему будет изменять ей и оставлять в одиночестве. Но таков выбор главной героини. Феминистки предоставили женщине свободу выбирать: терпеть мужские измены или же жить одной в свое удовольствие.

Сегодня для современных французских писательниц актуальным стал вопрос не борьбы за социальные права женщин и освобождения от стереотипов, а утверждения женственности, женской идентичности посредством литературного творчества.

Уже в середине 1980-х годов целостность феминистического движения уступила место наличию творческих индивидуальностей женщин-писательниц, не принадлежащих к определенному течению, движущихся каждая своим путем, создавая не общую идеологию, а личностное письмо.

К писательницам такого плана относится и Анна Гавальда, которая в своих произведениях демонстрирует независимость от общих настроений, от выходящего из моды феминизма. Она обладает даром писать так, что вроде и событий нет, и жизнь как у всех, как каждый день. В её произведениях нет ни надрыва, ни преувеличения.

Роман Анны Гавальда «Просто вместе» [4], при всей своей незамысловатости, очень чётко обрисовывает две социальные проблемы современности: одиночество и создание семьи. Развитие сюжета доносит до читателя идею о том, что семья единственный выход из состояния одиночества. Она же, то есть семья обеспечивает духовную гармонию и развитие личности.

Одна из центральных персонажей романа Камилла испытывает физическую и психическую слабость. У девушки проблемы с питанием, ужасные отношения с матерью, она страдает от анорексии. Эта слабость и тот факт, что из этого состояния ее выводят двое мужчин, является символом того, что Камилла воплощает собой женщину как слабый пол. Быть может, что её анорексия это нечто вроде бунта против 
образа, которого от нее ожидают окружающие. Мать Камиллы Катрин осуждает дочь, но упреки бесполезны. Камилла меняется только тогда, когда обретает мужчину, которого она считает достойным её, пусть поначалу и не признается себе в этом.

«Ради независимости? Тоже мне, достояние... Она много лет молилась на это слово - и чего добилась? К чему пришла? Живет в полуразрушенной хибаре и проводит время в размышлениях о своей несчастной судьбе, не выпуская изо рта сигарету! Как трогательно... Она и сама до невозможности трогательная... Ей скоро двадцать семь, а она ничего не накопила прозапас. Ни друзей, ни воспоминаний, похвастаться было нечем. Как это случилось? Почему она так и не сумела вцепиться мертвой хваткой и удержать при себе то, чем действительно могла бы дорожить? Ну почему?» [4, с. 69]

Социальное одиночество деформирует гендерные роли героев. Как только атмосфера становится более положительной, все трое начинают духовно меняться. Камилла занимает место хранительницы очага, когда начинает беспокоиться о квартире, пытается установить определенный порядок в доме и распорядок для мужчин. Франк бросает разгульный образ жизни, начинает готовить блюда не только на работе, но и дома, так как наконец есть для кого готовить, а Филибер становится более уверенным и решительным, избавляется от дефектов речи, противостоит ханжеским нравам своей семьи и находит себе невесту.

Феминистическая литература во всех ее вариантах выступает против представления о женщине как субъекте, нуждающемся в обязательной встрече с Прекрасным принцем. В этом отношении «женская проза» противостоит феминистской прозе. Тем не менее, между двумя литературными течениями собственно феминистическим и женским происходит своеобразный взаимообмен.

Несомненно, феминизм имеет историческую ценность: он был необходим, «когда женщины не имели права голосовать, когда их зарплаты были меньше, чем у мужчин. Сегодня женщины могут существовать свободно. И хотя современные молодые женщины не хотят быть феминистками, их романы содержат феминистические идеи уже потому, что представляют собой не «розовые» описания, а жесткие и жестокие жизненные наблюдения.

\section{Библиография:}

[1] Бовуар С. Второй пол. М.: Прогресс; СПб: Алетейа, 1997.

[2]. Засепская,Л.И.Творцы XX века: любовь и судьба / Л. И. Засепская. - СПб. : КАРО,2002. 168 с.

[3]. Ф. Саган // Любите ли вы Брамса?, Дивные облака, Немного солнца в холодной воде ; пер с фр. Т. Л. Черноситовой. — Ростов-н/Д. : Феникс, 2000.

[4]. https: // knigochei.net. Просто вместе. Анна Гавальда.

\section{INGLIZ BOLALAR YOZUVCHISI LYUIS KERROLL IJODIDA ALISA OBRAZINING YARATILISHI VA O'ZIGA XOS XUSUSIYATLARI}

\section{Sherqulov Sardor Komilovich ToshDO'TAU tayanch doktoranti}

Annotation: This article is about great Victorian writer Lewis Carroll's Alice Books, which was written as a gift to his children friends Alice Liddell and her two sisters. In Alice books, writer described Alice's adventures in Wonderland through fantastic situations in nostalgic mood.
Key words : Alice,

Victorian era, wonderland, fantasy, adventure, nostalgic mood.

Ingliz adibi, Viktoriya davri bolalar adabiyoti namoyondalaridan biri Lyuis Kerroll Alisa va uning sarguzashtlari haqida to'rtta asar yozgan bo'lib, asosan uning asarlari yosh bolalar uchun yozilganligiga qaramasdan o'smir kitobxonlar qalbidan ham joy olgan. Dastlab, "Alisaning yer ostidagi sarguzashtlari" (1864) asari yozuvchining uchta bolalar do'sti, Alisa 
Liddell hamda uning ikki singlisi bilan birga 1862-yildagi Iyul oyi tush paytdagi vaqtlarini Temza daryosi bo'ylab qayiqda o'tkazganlarida, ularga so'zlab bergan hikoyalar to'plamidan iboratdir. Alisa haqida hikoyalarini yozishda davom etgan ijodkor o'zining hikoyalarini yozib, Rojdestvo sovg'asi shuningdek birga o'tkazgan vaqtlaridan esdalik sifatida ularni taqdim etgan. Adibning ikkinchi kitobi "Alisaning mo'jizalar mamlakatidagi sarguzashtlari" (1865) asari haqiqiy ertaklarlar to'plamidan iborat bo'lib nashrdan chiqqan, ammo u Sir Jon Tennel tomonidan mahorat bilan rasmlar ishlangan, qo'shimcha qahramonlar Ahmoq Hatter, Quyon, badbashara gertsoginiya, uning sevimli mushugi Cheshire qo'shilgan. Yetti yildan so'ng, Kerroll ertaklar dunyosidagi bolalik davriga qaytadi, ammo o'sha vaqtda Alisa eski quyon teshigiga kirmaydi. "Alisaning Ko'zgular mamlakatiga sayohati va u yerda topganlari" (1871) asarida Alisa buning o'rniga xonadagi kamin ustidagi katta ko'zgu orqali Ko'zgular mamlakatiga sayohat qiladi, u yerda hikoyalar to'plami hamda bola uchun she'rlar kitobini topib oladi hamda shaxmat doskasining joylashish taritibini yaxshilab o'rganib olishni uddalaydi. Kitobning oxirgi nashrida "Bog'cha "Alisa" (1890), Mo'jizalar mamlakatidagi ko'p yillar avvalgi o'tkazgan vaqtini esga oladi, ammo bu kitob Kerrollning birdan besh yoshgacha bo'lgan juda yosh kitobxonlari uchun edi, chunki Kerroll epizodlarni muxlislarning ichki hissiyotlariga mos qilib yaratgan edi.

Alisa haqidagi asarning to'rtala nashrida ham, Kerroll bolalik haqidagi shirin xotiralar hamda XIX asrda Buyuk Britaniyada tarqalgan adabiy shakllarni yoritgan. Viktoriya davri o'smirlarining shuuriga bolalik ulkan kuch va yaxshiliklarni joylagan, shuning uchun ham bu davr avvalgi davrlar bilan qiyoslaganda uzoq davom etib, tez insonni tark etadigan shirin damlar ekanligini kitobxonlarga tushuntirishga harakat qilgan. Viktoriya davridagi ota-onalar bolalikni qadrlagan, hamda uni "yagona aybsizlik" deb aytab, bolalikni asrab, himoya qilib hamda uzoq davom etishini ta'minlab bergan. Bunday munosabat yosh bolalarning o'yinchoqlari, o'yinlari va kitoblariga ijtimoiy qadriyatlarni va bolalarining dam olishini qo'llab-quvvatlovchi vositalariga qiziqishning kengayishi va kuchayishiga olib keladi. Viktoriya davri asosiy mavzuni eskilardan asta-sekin voz kechish va kelajakka intiluvchi yangi g'oyaning asosi bo'lgan asr sifatida tasvirlangan.[5,121]

Afsuski, industrializatsiya va modernizatsiya kuchlari shu qadar chuqur madaniy o'zgarishlarni keltirib chiqargan ediki, ko'plab Viktoriya davri odamlari muqarrar taraqqiyot foydalari va mexanik ixtironing xavotirlari bilan tashvishlanishdi. Asrning so'nggi o'n yilliklarida, kattalar ko'pincha katta bo'lganda o'zlarining himoya va xavfsizligini eslab qolishgan va bolaliklarini tobora o'tmish Oltin asr g'oyasi bilan bog'laganlar.

Lyuis Kerroll o'z davridagi madaniy qo'zg'olonlarga javoban bolalar fantaziya adabiyotni yaratdi hamda bu orqali odamlar va jamiyatga yaxshi o'zgarishlar bo'lishini ko'rsatdi. Hayot tajribasi tufayli oxir-oqibat charchagan yoki qo'rquvga tushadigan kattalardan farqli o'laroq, bolalar hayotni boshqacha bir qiziqish bilan qabul qilishdi va o'z tasavvurlari orqali yangi dunyoni ishtiyoqlari bilan yaratishga kirishdi.

Ushbu matnlarda, avvalo, Alisani u uchratgan jumboq, tez aytishlar va personajlar, yodlagan she'rlar va qiziquvchan personajlarning nafisligi maftun etadi. Afsuski, xayoliy qahramonlarning aksariyati tanqidiy, talabchan va hatto tahdidli ekanligini namoyish etadi. Ammo, tobora qizg'in to'qnashuvlar paytida, Alisa o'zini o'zini haddan tashqari har bir narsadan ogoh bo'lib, uni obro'sizlantiradigan, beparvo va shafqatsiz kattalarga qarshi o'zini himoya qilishni o'rganadi va u o'ziga ishonch bilan voyaga yetadi. [3,45]

Bolaligida Alisa ham vaqti-vaqti bilan o'zini odamlardan olib qochadi, ammo uning o'zini anglash darajasi xayoliy dunyo madaniyatiga moslashish qobiliyati oshiradi, u duch kelgan mavjudotlar esa statik va bir tomonlama bo'lib qoladi. Alisaning psixologik o'sishi va Kerrollning hayotga nisbatan qat'iy nuqtai nazari bilan bolaning hayotga munosabatini aks ettirgani sababli, uning sarguzashtlari oxir-oqibat Alisa uchun ajoyib xotiralar qoladi va ushbu xotiralar kitobxonlarga manzur bo'ladi. [1,119] 
Biroq, Kerroll odob-axloqni butunlay esdan chiqargan desak xato bo'ladi, albatta u faqat kitobxonlarni xushnud etish uchun yozgan. Ikki g'aroyib orzular mamlakatida sayr qilib yurgan bu qiziquvchan yosh qizlar haqidagi hikoyalari yanada chuqurroq, o'zgaruvchan maqsadga ega va kuchli paradoksni yaratadi: orqaga nazar tashlab, ikkita g'alati xayolot olamini bola, yosh va qari kitobxonlarning nigohi bilan o'rganish orqali har xil ma'lumotni olish mumkin hamda hayotning qiyinchiliklarni yengib o'tish uchun insonda ishonch hissini hosil qiladi.[4,55] Kerroll aqlli so'z o'yinlari va mavzuga aloqadorligi bo'lmagan kitoblar nomutanosibligi orqali ertak tuzilishini mohirona aniqlab beradi va bolalarning xayoliy adabiyotiga shunday chuqur xayoliy iborani qo'shadi, shunda F.J.Xarvi Darton birinchi nashr etilgan Alisa haqidagi asarni: "Bolalar kitoblarining ma'naviy vulqoni" deb belgilaydi.

Ushbu asar dastlab nashrga berilmagan hamda hujjatsiz shaklda bo'lib, u faqat bolalar kitobidagi fikr erkinligiga muhtoj bo'lgan kitobxonlargagina xos bo'lgan. O'sha davrlarda axloqiy qadriyatlar, mulohazalar, ijoyib sifatlar haqida vahima uyg'otishga hatto vaqt ham bo'lmagan. Ushbu xislatlardan rohatlanish mumkin edi, afsuslanish o'rniga tadbirlilik muhim o'rin tutgan. Kerroll o'tmishni qayta yaratilishi yoki hatto taqlid qilinishi kerak bo'lgan narsa sifatida qaramaydi, garchi Mo'jizalar mamlakatida Alisaning orzusudagi go'zal bog' mavjud bo'lsa-da, bu xayolot dunyosida o'ylab topilgan joy sifatida hisoblamaydi. Aksincha, "Mo'jizalar mamlakati" va "Ko'zgu ortidagi mamlakati" - yashash uchun xos bo'lmagan noqulay joylar chunki bu yerda Alisani haqorat qiladigan va unga yomon munosabatda bo'lgan o'z-o'ziga xizmat qiladigan, hukmron va sezgir kattalar bilan gavjum joylardir. Natijada, Alisa o'zligini, odatiy shakl-o'lchamini hattoki, hayotini yo'qotayotgandek his qilardi. Alisa bilan uchrashgan katta insonlar jamiyatning turli xil vakillaridan edi, masalan, ta'lim, jamiyat, siyosat va boshqalar, ularning harakatlari Alisa va kitobxonlarga ahmoqona tuyular edi.

Xayolot dunyosida kattalarning ahmoqona xatti-harakatlari Kerrol ko'rsatib bergan hamda ularning harakatlari bolalar adabiyotida oqilona va mulohazali deb yoritilgan, ammo bolalar esa kuchsiz va adolatli qilib tasvirlab berilgan. Ammo Kerolning ta'kidlashicha, agar turli xil xayoliy belgilar bilan ifoda etilgan ijtimoiy va madaniy mafkuralar tekshirilmagan bo'lsa, mantiqiy chegaralarga olib borilganda ular bema'nilik bo'lib ko'rinishi mumkin, ammo ular cheklovchi, vayronkor va shafqatsiz bo'lishi mumkin. U qiziquvchan boladan foydalanib, ushbu pozitsiyalarning qonuniyligini va ularni qat'iy ushlab turadigan ijtimoiy tizimlarni borligiga ishonchsizligini bildirgan. Alisa xayoliy olamda hayot bilan kurashishning an'anaviy usullarini mutlaqo samarasiz deb bilganida,u qonuniyatdagi amaliy madadni xohlaydi va Viktoriya davrining ta'lim va ijtimoiy me'yorlariga muvofiq ravishda har doim to'g'ri bo'lishini istaydi va bolalarcha tabiatiga murojaat qiladi. Ushbu jarayonlarda Alisa atrofidagi g'alati vaziyatlardagi chidamliligini hamda inson sifatida o'zining shaxsiy sifatlarini shakllantiradi. Alisaning xayolot dunyosidagi Kerrolning asosiy vazifasi umidning birgina uchqunining borligi, bolalarning shaxsiy ishonchga hamda jadal rivojlanayotgan dunyoni o'zgartirishga qodir ichki hissiyotlarning majmuasiga egalik qilayotganini yaqqol ko'rishimiz mumkin. Kerrollning shaxsan o'zi uchun Alisa bir necha bor xayoliy qahramonga aylandi, u maxsus kichkina qiz va uning singillari bilan bo'lishgan yoqimli haqiqiy voqeani aks ettirdi va uni butun hayotni qadrlaydigan hissiy aloqa bilan bog'ladilar.[2,260]

Tomoshabinlar Alisaning sarguzashtlarini o'zlarining ibtidosidan farqli ekanligini angladilar, Kerrolning mahoratli ijodi, murakkab namoyishlari, kulgili parodiyalari ham bolalar ham kattalar qalbidan joy oldi. Hozirgi hamda kelajakdagi hayotning ma'suliyatlarini yengib o'tgan katta kitobxonlar kitobda mavjud bo'lgan qo'shiqlar, she'rlar, hikoya qahramonlari, bolalar she'rlaridagi ajib bir go'zallikni anglashdi. Hayot tajribasiga hamda kuchli aqliy ongga ega bo'lgan kattalar ma'no-mazmun darajalari, chalkashlik nashidalari hamda filosofik qiyinchiliklarni keng qamrovda tushuna olishadi. Shu sabablarga ko'ra, Kerroll realistik yo'nalishga qaraganda fantaziya yo'nalishini tanlagan, chunki kattalar 
xayolida kulgili parodiyalar hamda kinoyalar ayrimlar insonlar uchun tanqidiy, ayrim inson guruh yoki turlari uchun kuchsizlik belgisi bo'lib ko'rinishi mumkin.

Keyinchalik Kerrol tomonidan yaratilgan matnlar matnlari madaniy bir ko'zguga aylanib, xayoliy yozishda tabiiy ravishda mavjud bo'lgan ekstremallar tomonidan buzib ko'rsatildi, ammo shunga qaramay, ijtimoiy dinamikani va madaniy taxminlarni o'rganishni rag'batlantiradigan ijtimoiy tuzatuvchi sifatida qaraladi. Biroq, Kerrol bu asarni birinchi navbatda bolalar uchun yozgan. Ko'pincha hayotning o'zgaruvchanligini boshdan kechiradigan va ko'pincha katta bo'lishni va kattalar rolini qo'lga kiritishni intizorlik bilan kutayotgan bolajon kitobxonlar Alisani o'zini o'zi bilan kurashda va uning atrofidagi g'alati kattalar bilan bo'lgan yomon muomalalarida qay holatda bo'lganligini ko'rib, unga yaqinlashishadi. Xayoliy muhit bolalar uchun xavfsiz muhitni ta'minlaydi, chunki bu ularning haqiqiy dunyosidan uzoqdir va bu o'zlarining qo'rquvlarini o'rganishga imkon beradi, chunki bolalik, shuningdek, madaniy konventsiyalarni qabul qilish yoki rad etish bilan birga, shaxsiyati shakllantiradigan davrdir. Shunga qaramay, bolalar an'anaviy adabiy janrlarni qadrlaydilar, ular o'zlarining intertekstual adabiy qobig'larini yaratish bilan birga, o'zlarining o'tmish bilan bog'liq qadriyatlarini o'zgartiradilar va yangi usullarni kashf etadilar. Ular hikoyaviy motivlarni taniydilar va psixologik jihatdan ishonchga ega bo'ladilar, chunki ular Alisaning qiyin sarguzashtlari oxir oqibatda baxtli yakun topishiga ishonadilar.

\section{Adabiyotlar:}

1. Charles Frey and John Griffith, The Literary Heritage of Childhood (Westport, CT: Greenwood Press, 1987).

2. Children's Books in England, 3d ed. (Cambridge, England: Cambridge University Press, 1982).

3. Edmund Little, The Fantasts (Amersham, England: Avebury, 1984).

4. Jackie Wullschlager, Inventing Wonderland (New York: The Free Press, 1995).

5. Karen Smith, The Fabulous Realm: A Literary-Historical Approach to British Fantasy, 1780-

1990, (Metuchen, N.J.: Scarecrow Press, 1993).

\section{ADABIY TA'SIRNING IJOBIY NAMUNASI}

Ochilov E.

QarshiDU o'qituvchisi

Annotation: This given article is about the role of artistic translation with interinfluence and interaction of the national literature on the examples of English and Uzbek prose. The famous English novel "The Picture of Dorian Grey" by O.Wilde and the Uzbek short story "Oh, Life!" by Zulfiya Kuralbay qizi are under consideration.

Umumjahon adabiy jarayoni murakkab hodisa bo'lib, unda ishtirok etuvchi milliy adabiyotlar bir-birlari bilan uzviy aloqada bo'ladilar. Hozirgi kunlarda jahon adabiy jarayoni, jumladan adabiy aloqalar jadal sur'atlar bilan rivojlanib bormoqda. Bunga badiiy tarjimalarning salmog'i tobora oshib borayotgani alohida hissa qo'shmoqda.

Biz ushbu maqolada yosh o'zbek adibasi Zulfiya Qurolboy qizining ijodida atoqli ingliz adibi Oskar Uayldning, jumladan uning O.Sharafiddinov tomonidan tarjima qilingan «Dorian Greyning portreti» nomli mashhur asarining sezilarli darajada ta'siri haqida to'xtalmoqchimiz.

Darhaqiqat 1855-1900-yillarda yashab ijod etgan ingliz adibi Oskar Uayldning «Dorian Greyning portreti» romani hayot haqida, insonning azal-azaldan o'limni yengib, abadiy yashash istagini amalga oshirishga urinishi haqida. Zulfiya Qurolboy qizining «0, hayot!» nomli hikoyasi ham aynan shu mavzuda. Bu ikki asarni bir-biridan farqlovchi jihatlari birining roman, ikkinchisining hikoya ekanligi bo'lsa, birining qahramoni yosh ingliz yigiti Dorian Grey, ikkinchisining qahramoni esa keksa o'zbek kishisi Nazar choldir.

Dorian Grey o'zining rassom Bezil Xolluord chizgan portretini ko'rib, o'z chiroyidan o'zi lol qoladi va rassom qarshisida quyidagicha xitob qiladi: 
«- Naqadar qayg'uli! Men qariyman, jirkanch bir badbashara kimsaga aylanaman, suvratim esa mangu navqiron bo'lib qolaveradi... Oh, koshki buning aksi bo'lsa? Ana shu suvratim qarisa-yu, men mangu yoshligimcha qolaversam!... Buning uchun men olamdagi bor narsani berishga tayyorman. Ha, hech narsamni ayamas edim. Buning uchun hatto jonimni ham beraman!» $[2,19]$.

«0, hayot!» hikoyasining qahramoni Nazar chol ham yetmish beshga chiqqaniga qaramay uzoq umr ko'rishni, abadiy yashashni orzu qiladi. Nazar chol birdan ko'rpa-to'shak qilib yotib qoladi...O'g'li otasini do'xtirlarga ko'rsatadi, kunora tanish-bilishlar, qo'niqo'shnilar kirib undan hol so'rab turishadi. Bir kuni hol so'rab chiqqan qo'shnilarga kampiri Oynisaning sekingina:

«-Vaqti-soati yetgan bo'Isa ne qilamiz! Hammamiz ham bir kunmas bir kun ketamizda u dunyoga, - deganini eshitib qoldi-yu, cholning butun vujudi titrab ketdi» [3,34] va o'rnidan irg'ib turib, hovliga chiqib ketdi.

Nazar chol hovlida shunday fikr yuritadi: «Mayli, hech kim bor-yo'g'idan xabar olishmasa ham, shu yorug' dunyoni, hayotni tark etmasa. Hech narsa kerak emas, hech narsa! Hammasini berdim ularga! Manavi hashamatlar - hovli-joy, mol-hol, qo'r-quti - hech biri kerak emas. Bir vaqtlar shu anjomlar uchun jonini jabborga berib ishlagan kunlarini eslab cholning jahli chiqdi. Hammasi behuda, hammasi arzimas matoh! Faqat yashash, yashash, yashash! Qaniydi mangu yashasa...» [3,34].

Nazar chol hamisha o'zini navqironman, deb hisoblaydi, atrofida jo'sh urayotgan hayotdan zavqlanadi, shu go'zal hududni tashlab ketishni aslo istamaydi:

«Chol bundan 75 yil muqaddam emas, xuddi kecha tug'ilgandek olamga hayrat nigohi ila boqib, hech undan ko'ngil uzolmasdi. O, hayot! Qanchalar go'zal! Tip-tiniq osmon, yorug'lik, yam-yashil barglar, allaqanday, chol hatto nomini ham bilmaydigan chiroyli gullarning yoqimli hidi, ariqchada jildirab oqayotgan suv! E-he, bularni qanday qilib ko'z qiyadi» [3,34].

Ikkala asar qahramonlari uzoq umr ko'radilar, biroq ularning do'st-birodarlari, yaqinlari, sevimli insonlari turli sabablar bilan olamdan o'tadilar: Dorian Greyni chin dildan sevib qolgan aktrisa Sibila Veyn sevgisi rad etilgach, o‘z joniga qasd qiladi, portretini chizib bergan do'sti Bezil Xolluordni Dorianning o'zi pichoqlab o'ldiradi, yana bir do'sti Alan Kempbel uni deb o'zini-o'zi o'ldiradi, singlisi Sibila uchun o'ch olmoqchi bo'lib yurgan uning akasi Jeyms Jeffri Klaustonning o'qidan halok bo'ladi.

Nazar cholning o'g'li Alisher halokatga uchrab, dunyodan ko'z yumdi, bu ayriliqqa chidamagan kampiri bahor kunlarining birida "puf» dedi-yu, jon taslim qildi-qo'ydi», kelini «oltmish besh yoshida, yerto'laga tushayotgan mahal qoqilib ketib o'sha yerning o'zida jon taslim qildi».

Biroq har ikkala qahramonni ham faqatgina o'zini o'ylaydigan, xudbin insonlar deb bo'lmaydi. Ularning ham qalblari bor, ularning ham qalblari mehr-muhabbatni biladi, ular ham ba'zan kuladi, ba'zan yig'laydi. O'g'li Alisher olamdan o'tganida Nazar chol «tirik arvohdek hovlida g'imirlab yurardi. U ham og'ir ahvolda qolgandi. O'g'lini qo'msab, pana-panada yig'lab olar, ammo hech vaqt kampiri, kelini singari o'ziga o'lim tilay olmasdi» [3,35] yoki «kunlarning birida hovlidan qiy-chuv, yig'i-sig'i ovozi eshitilib qoldi. Evaralaridan biri olamdan o'tdi shekilli! Chol to'ng'ich nevarasining o'g'lini elas-elas ko'z oldiga keltirib, yuragi bir hapqirdi. Anchadan beri ko'ngli bu qadar yumshamagan edi. Nahotki yolg'izlik jonidan o'tgach yaqinlarining yo'qligi bilingan bo'lsa?» [3,36].

Dorian Grey esa o'zi amalga oshirgan jinoyatlariga pushaymon qiladi: «Ertasiga Dorian kun bo'yi uydan chiqmay, vaqtning ko'p qismini o'zining xonasida o'tkazdi... Nega u telbaligi tutgan mudhish daqiqada qadrdon do'stini o'ldirdi? Bu manzarani eslashning o'zi naqadar mudhish!... Lord Genri soat oltida Dorianning yotog'iga kirib kelganda u alamli ko'z yoshlariga g'arq bo'lib o'tirgandi. Dorian qalbi g'am-g'ussadan pora-pora bo'lib ketgan odamday ho'ngho'ng yig'lardi» $[2,43]$. 
Dorianni vijdon azobi ko'p qiynaydi, qilgan jinoyatlariga loyiq jazo olishini istaydi va Bezil portretini chizayotgan paytda abadiy navqiron qolish haqida xudodan iltijo qilgan kuniga la'natlar o'qib, ixtiyoriy ravishda hayotdan ko'z yumadi. Biroq O.Uayldning «Dorian Greyning portreti» romanidan farqli o'laroq, Zulfiya Qurolboy qizining «0, hayot!» hikoyasining yechimi o'zgacha.

Nazar ota Dorian singari gunohlarga botmagan, yaqinlarining o'limida ham uning aybi yo'q. Biroq uning yagona aybi, istagi - mangu yashash. Kampiridan keyin kelinining o'limidan so'ng uni oshxona yonidagi hujraga ko'chirib o'tqazishadi, yana bir muncha vaqt o'tib Nazar chol yoshini hisoblashdan adashadi, ko'zlari ko'rishdan, quloqlari eshitishdan qoladi - hamma uni endi o'lsa kerak, deb o'ylardi. "Chol esa ularni ko'rmasdi, eshitmasdi, ammo g'ayri-shuuriy ravishda kimlardir tomosha qilayotganini sezib qolib, qo'liga ilingan narsani - kosami, choynakmi olib, eshikni mo'ljallab turib uloqtirardi.

So'ng esa avvalgidan ham teranroq, avvalgidan ham ravshanroq mulohaza yuritib, ko'ngli quvonchga to'lardi. Men endi haqiqiy hayotimni yashayapman! Men yashayapman!» $[3,36]$. Xulosa shuki, mustaqillik davrida jahon xalqlari adabiyotlaridan o'zbek tiliga qilinayotgan tarjimalar, xoh ular bevosita bo'lsin, xoh bilvosita, o'z samaralarini bermoqda. Biz bu bilan jahon adabiyoti klassiklari o'zbek adiblariga to'g'ridan-to'g'ri ta'sir o'tkazmoqdalar, demoqchi emasmiz. Eng muhimi shundaki, bu tarjimalar bilan yaqindan tanishib, yosh o'zbek adiblari dolzarb mavzular topishni, yorqin obrazlar va xarakterlar yaratishni o'rganmoqdalar, yangicha mushohada yuritib, yangi yo'nalishlarga chiqmoqdalar. Zulfiya Qurolboy qizining biz yuqorida ko'rib chiqqan hikoyasi fikrimizga dalil bo'la oladi.

\section{Adabiyotlar:}

1. Ўзбекистон адабиёти ва санъати, 2005 йил, 20 май.

2. Уайльд, О. Дориан Грейнинг портрети. Озод Шарафиддинов таржимаси. // Жахон адабиёти, 2000, № 1 .

3. Зулфия Қуролбой қизи. 0, хаёт! // Ёшлик, 2001 йил 2-сон.

\section{THE INFLUENCE OF SHAKESPEAREON THE WORLD LITERATURE}

\section{Egamnazarov Kobil SamSIFL, teacher}

Annotation: This article provides statements on the theoretical and practical significance of the research of the famous Czech linguist V. Matesius on the theory of the separation of speech into relevant parts and the phenomenon of accession. Attempts have been made to explain the concepts of rema and topics, which are important parts of speech, in the framework of the connecting structure.
Key words : William Shakespeare, the world literature, period, Hamlet influence.

William Shakespeare was an English playwright, poet and actor, widely regarded as the greatest writer in the English language. He is often called England's national poet. He had a greater influence on the world literature than any other author. His plays have been translated into every major living language.

William Shakespeare was born in 1564, on April 23 in Stratford-on-Avon. His father, wasJohn Shakespeare, was a prosperous glove maker of Stratford. Shakespeare's mother, came from family of landowner. Together they had eight children. Shakespeare became eldest child in family. In his childhood Shakespeare attended the Stratford Grammar School. At the age of 18, he married Anne Hathavay. They had three children:Susanna and twins Hamlet and Judith.

His extant works including collaborations, consist of approximately 39 plays, 154 sonnets, two long narrative poems, and a few other verses. Shakespeare produced most of his known work between 1589 and 1613. Some of Shakespeare's plays were published in quarto 
editions, beginning in 1594, and by 1598 his name had became to appear on the title pages. He continued to act in his own and other play after his success as aplaywright.

Throughout his career, Shakespeare divided his time between London and Stratford.In 1599 the best known of Elizabethan theatres, the Globe, was built and Shakespeare became a leading shareholder and the principal playwright to the theatre company. He was also an actor, but not a first- rate one :the parts he played. In 1613, after the Globe had been destroyed by fire he retired and stopping writing.

Shakespeare's Plays

Most scholars agree that there that there exist 37 plays written by Shakespeare. Traditionally, his plays have been divided into three groups: comedies, histories and tragedies. All of the works of the playwright are written in four periods of his literary career.

THE FIRST PERIOD includes all plays written in 1590- 1594. His comedies "The Comedy of Errors", "The Taming of the Shrew", " The Two Gentlemen of Verona", the histories "Henry VI" , " Richard III" , and the tragedy "Titus Andronicus" were written during this period. The plots of these plays follow their sources more mechanically then do the plots of Shakespeare's later works.

During SECOND PERIOD(1595-1600) Shakespeare brought historical drama and Elizabethan romantic comedy to near perfection. The comedies " A Midsummer Night's Dream", Love's Labour's Lost", " As you like it", the tragedies " Romeo and Juliet" , " Julius Caesar" and the histories " Richard II" , "Henry V" were written at this period, the great playwright demonstrated his genius for weaving varuos dramatic actions into a unified plot.

During THE THIRD PERIOD(1601-1608) wrote his tragedies, which made him truly immortal. Every play of this period shows Shakespeare's awareness of the tragic side of life. And also Shakespeare's sonnets were also written during the third period of his literary career.

THE FOURTH PERIOD(1069-1613). During this final period Shakespeare wrote three comedies and the history "Henry VIII".

The last year of Shakespeare's career as a playwright are characterized by a considerable change in the in the style of drama.

The ten best Shakespeare plays of all time:

1. HAMLET - was written in 1600 and about a student ponders the meaning of life when he should be on a killing spree.

2. MACBETH - is about a Scottish lord is persuaded to commit brutal murder by his wife, who promptly gets all guility about it(1605)

3. MIDSUMMER NIGHT'S DREAM - this = play is about a bunch of insane fairies attempt to solve the romantic problems of some mortals lost in a wood(1595)

4. MUCH ADO ABOUT NOTHING - was written in 1598 and about extreme sassiness in the Sicilian countryside.

5. KING LEAR - is about a father of three takes early retirement and goes a little bit nuts(1605)

6. OTHELLO - was written in 1604 and about what happens when race relations in sixteenth century Venice don't terrible well

7. TWELFTH NIGHT - was written about a Shakespeare trope overload: romantic cross-dressing with twins and a shiowreck(1599)

8. THE TEMPEST -is about Sorcerer and single dad Prospero takes revenge on his enimies - magic style(1611)

9. ROMEO AND JULIET - is about the children of mortal enemies fall for each other. It gets a bit(1594)

10. THE MERCHANT OF VENICE - this play was written in 1596 and about things get a teeny bit anti-Semantic when a Venetian noble defaults on a loan to a Jewish merchant(1596) Shakespeare's Sonnets 
In addition to his plays and two narrative poems , he wrote 154 sonnets. Shakespeare's sonnets occupy a unique place in the Shakespearian heritage, because they are only lyrical pieces, the only things he was written about himself. By reading between the lines of the sonnet, we may see a tragedy in Shakespeare's life. Scholars and critics have made many attempts to discover all the mysteries of Shakespeare's sonnets, as they may shed light on his life, but generally to no avail. It is important to remember that his sonnets were written at a time when such sequences were fashionable, and thus the sonnets maybe more an exercise in literary convention than in autobiography.

Throughout the 20th and 21st centuries, Shakespeare's have been continually adapted and rediscovered by new movements in scholarship and performance. His plays remain popular and are studied, performed, and reinterpreted through various cultural and political contexts around the world.

Shakespeare died on 23 Aprel in 1616 at the age of 52 .

In conclusion, William Shakespeare undeniable made a huge impact on the world. To this day,Shakespeare still manages to influence people, young and old, through his works. Shakespeare helped create the literature we know today by combining classical and medieval literature also influencedtheatre by emphasizing literary devices and combining genres. William Shakespeare has not been alive for many centuries, he still leaves behind an everlasting legacy.

1. Adams , Joseph Quincy.

List of used literatures:

2. A life of William Shakespeare.Boston

3. Schoenbaum 1987.

4. M. Barakayeva, E. Muratova, M. Ochilova. English literature.

5. U. Hamdamov, A. Qosimov. Jahonadabiyoti.

\section{ТОҒАЙ МУРОД ҚИССАЛАРИДА ЎХШАТИШ ТАСВИРИЙ ВОСИТА СИФАТИДА}

\section{Кобилов Номоз Ўролович Самарқанд Давлат Университети мустақил изланувчиси}

Annotation: This article provides feedback on the role of analogy in the expression of the Uzbek mentality. The author of the article tried to express his views on the basis of factual materials taken from the stories of uncle Tagay Murad.
Key words : analogy, text, image lingvoculturology, speech, medium, linguocultural unity, verbal communication, narrative, work, protagonist and so on

Бугунги кунда миллий тилшунослигимизга замонавий тилшуносликнинг социолингвистика, психолингвистика, нейролингвистика, прагмалингвистика, лингвокультурология сингари йўналишлари дадил кириб келмоқда. Уларнинг асосий тадқиқот объекти бўлган матн орқали инсон омилининг лисоний хусусиятларини очиб беришдан иборатдир.

Инсон нутқи орқали унинг ўзига хос менталитетини ифодаловчи воситалардан бири ўхшатиш хисобланади. Нарса ва ходисалар ўртасидаги ўхшашликка асосланиб, уларнинг бири орқали иккинчисининг белгисини, мохиятини тўлароқ, аниқроқ, бўрттириброқ кўрсатиб бериш ўхшатиш дейилади[1.,99]. Демак, матнда инсон нутқининг ўзига хослигини таъминловчи воситаси бўлган ўхшатишларни лингвомаданий бирлик сифатида тадқиқ этиш тилшунослик фанининг долзарб 
масалаларидан бири эканлиги билан мухим ахамият касб этади. Албатта, бу жараён кўпроқ сўзлашув нутқига оид мулоқотлар натижасида намоён бўлиши, табиийдир.

Хақиқатан нутқий мулоқотнинг юзага чиқиши учун мухит зарур восита бўлиб, бу бевосита бир шахс нутқ фаолияти билан боғлиқ бўлган худуд ёки миллатга хос менталитет билан боғлиқ равишда юзага чиқади. Бу эса проф. Ш. Сафаров таъкидлаганидек, “Нутқий мулоқотда ахборот узатиш “юки”, сўзсиз, лисоний бирликлар “елкаси”га тушади, аммо шахслараро муносабат нормасини, миллиймаданий қадриятлар тизимини эгалламасдан туриб, тўлақонли мулоқотга киришишнинг имкони йўқ"[2., 108]. Шу боис хам бадиий асар қахрамонларининг прагматик нутқини ўрганиш орқали инсон омилини жиддий тадқиқ этиш мумкинлиги кейинги йилларда яратилаётган тадқиқотларда ўз аксини топмоқда.

Мазкур ишимизда хозирги ўзбек насрининг яловбардорларидан бири бўлган Тоғай Мурод қиссаларида қахрамонлар нутқий мулоқотида қўлланган ўхшатишлар юзасидан олиб борган кузатишларимиз юзасидан олган мулохаза ва хулосаларимизни баён қилишга харакат қиламиз.

Адиб ўз асарларининг мазмундорлигини ошириш мақсадида халқона бадиий тасвир воситаларидан унумли фойдаланган. Жумладан, у метафоранинг бир ажралмас бўғини бўлган ўхшатишдан халқона охангларга уйғун тарзда қўллашга харакат қилган. Эътиборингизни адиб қиссаларидан олинган қуйидаги далилиларга қаратамиз:

Полвонлар кўпкарига боқилмиш отдай асов- асов бўлади[3., 19]. Бу ерда чавондозларнинг улоқ ўйинига тушишларидан олдинги холати тасвирланган бўлиб, уларнинг бу жараёндаги ўзларини тутиш жараёнлари, рухий холатлари минилмаган асов отларга ўхшатилган.

Полвонлар мисоли оғир тош бўлади[3.,25]. Бунда полвонларнинг оғир табиатли бўлиши оғир тошга ўхшатилиб, унча-мунча гап-сўзларга жахли чиқавермаслиги ва майд-чуйда гапларга эътибор бермаслиги тасвирланган.

Фарзандлар ўзлари минаётган машинага ўхшайди! [3.,29]. Машинани бошқариш мураккаб жараён бўлгани каби фарзанд тарбиясини ўта хушёрлик олиб борилиши зарурлиги назарда тутилган холда уларнинг фаолияти машинани бошқаришга ўхшатилганлигини кўриш мумкин.

Теварак сув қуйгандай жимжит бўлди. [3.,58]. Бу ерда маълум бир холатдан кейин хамма томонда сокинлик хукмрон бўлиши сув сепганда чанглар босилиши холатидагидай жимжитликка ўхшатиляпти.

Юлдузлари тандирдан энди узилган нондай қизил,мўйловли бир одам улоқ бошига келди. [4.,74]. Бу ерда истараси иссиқ, юзи қизил рангли киши, мўйловли киши хозир тандирдан узилган иссиқ нонга ўхшатилган холатда тасвирланган.

Кўпкари томошага келганлар шу тут шохларида деворда турган чумчуқдай тузилиб ўтирди.[4.,74]. Дарахтда ўтириб кўпкари томоша қилаётган ишқибозларнинг холати дарахтда тизилиб ўтирадиган қушлар холатига ўхшатилган.

Тошдай қоронғу тушди[4.,35]. Атрофнинг инсон кўриб бўлмайдиган даражада жуда қоронғи эканлигини кучайтириш мақсадида ифодаланган.Сув илондай чопди! Улоқни кетма-кет икки бор айирди. [4.,96]. Сув илони бошқа илонларга қараганда тез харакат қилиш полвоннинг чаққон харакат қилишига моманд тарзда тасвирланган.

Эртаси куни Душанбега учдим.Ўтирганлар шаходат бармоғини ликкиллатиб, ўртада лайлак қушдай лўкиллаб юрган қизни имлади[4.,96]. Самолёт учаётган пайтда страдюссанинг харакати лайлакнинг юриш холатига ўхшатилган.

Тарлон юлдуз учгандай чопди[4.,100]. Отнинг тез чопиши осмондан юлдузнинг учиш холатига ўхшатилган тарзда тасвирланган.

Майиз бизда бор-да! Олти унхалта!Саратондай сариқ майиз! [4.,101]. Майизнинг ранги ўта сариқлиги ва яхши пишганлигига ишора қилинмоқда. 
Қўчқордай-қўчқордай ̆ғнлларим бор! [4.,101]. Ўғлиларининг ўта бақувватлигини бошқаларга мақтанган холда тасвирланмоқда.

Ботинкалари товони от туёғидай-от туёғидай қалин -қалин эди. [4.,103]. Полвонларнинг оёқ кийимлари ўкчаси қалинлиги отнинг туёғидек қалинлига ўхшатиляпти.

Ёмон от -ёмон аёлдай гап! (115-бет, 62). Бу ерда отнинг ёмони, яъни кўпкарида хар хил қилиқлар чиқариши характери унчалик яхши бўлмаган аёлнинг қайсарлигига менгазиляпти.

Теваракда майда-майда адирлар бўлди. Арғамчидай йўл бир юқорилади бир адоқлади [4.,131]. Тоққа олиб чиқувчи сўқмоқнинг арқондай узунлиги ва торлиги тасвирланган.

Адиб қиссалари тахлиллари шуни куррсатдики, унинг қиссалари қахрамонлари мулоқотида ўхшатишлар сурхондарёликларга хос худудий менталитетни ифодаловчи луғавий бирликлар сифатида адабий тил меъёрларига хамоханг тарзда импровизацион махорат билан уйғунлаштирилганлиги боис асар сюжетининг янада пишиқ ва қизиқарли бўлишини таъминлашга қаратилганлиги билан мухим ахамият касб этади. Бу эса ёзувчи асарларининг линвокультурологик хусусиятлари кенг ва атрофлича тадқиқ этиш тилшунослар олдида турган долзарб масалалардан бири эканлигидан далолат беради.

\section{Адабиётлар}

1. Қўнғуров Р., Бегматов Э., Тожиев Ё. Нутқ маданияти ва услубият асослари.Тошкент: Ўқитувчи, 1992.

2. Сафаров Ш. Прагмалингвистика. -Тошкент: “Ўзбекистон миллий энциклопедияси" Давлат илмий нашриёти,2008.

3. Тоғай Мурод. Юлдузлар мангу ёнади. -Тошкент: Шарқ нашриёти, 2008

4. Тоғай Мурод От кишнаган оқшом. -Тошкент: “Sino-standart”, 2017.

\section{ТАРЖИМАДА МИЛЛИЙ ҚАДРИЯТЛАРНИ САҚЛАШ МУАММОЛАРИ}

\section{Халмуратов Иззатилла Наъматиллаевич Ўзбекистон Давлат Жахон Тиллари Университети магистр талабаси}

Annotation: Compound words and their translation, preservation of mentality, national values and customs in the text of translation, linguocultural aspects of translation are discussed in this article. The author of the article tried to explain the reader the complexities, which the translator faces during his work. He gave number of examples that clearly show the difficulties in the translation process.
Key words: compound words, equivalency, values, spirituality, transliteration, transcription, transference, word components.

Таржимашуносликда замонавий тадқиқотларнинг объекти хисобланадиган бир неча муоммолар мавжудки, улар кўп жихатдан тадқиқ қилинишни талаб қилади. Ана шундай долзарб муаммолардан бири қўшма сўзлар ва уларни таржима қилиш билан боғлиқдир. Таржима жараёнидан қўшма сўзларни таржима қилиш таржимон учун бир мунча қийинчилик туғдиради. Чунки, таржимон таржима жараёнида қўшма сўзлар компонентларини тўлиқ идрок этмаслиги мумкин. Бундан ташқари, миллий қадриятларни англатувчи қўшма сўзларни таржимада акс эттириш хам таржиманинг ўзига хос муаммоларидан хисобланади. Таржимашунослик хусусида Ўзбекистонда Ғ.Саломов, Қ.Мусаев, Г. Ғафурова, Л.Абдуллаева, С. Саломова, 3. Умарбекова, М. Турсунхужжаева, Д. Ғуломова, Х. Авлоновалар, хорижда эса Швецер, Рацкер, Бархударов, Крупнов, Миньяр-Белоручев, Нида, Савори,Чернов, Ширяевлар тадқиқот ишлари билан шуғулланишган. Аммо бадиий таржимада миллий қадриятларни англатувчи 
қўшма сўзлар, уларни таржима қилиш усуллари, эквивалентлик муаммолари хусусида тадқиқотлар етарлича олибборилмаган.

Таржима-бир тилда яратилган муайян асарнинг ўзга бир халқ маънавий эхтиёжига хизмат қиладиган, ундан бадиий завқ олиши учун имконият яратувчи коммуникатив воситадир. Таржима матни хам аслият матнига тенг бўлиб, у билан бир яхлитлик тасаввурини уйғотиши керак. Шунга биноан, таржима вазифаларидан биритаржима матни аслиятнинг тўлиқ коммуникатив ўрнини эгаллаши ва аслият ўқувчиси имкониятига тенг даражадаги бадиий завқ мундарижавий (структуравий) уйғун мувозанатни таржима ўқувчисига тақдим этишидир.

Бу борада профессор Ғ.Хошимов хам ўзининг «К теории метаязыка транслятологии» номли мақоласида қимматли маълумотларни келтириб ўтган. Хусусан, олим таржиманинг назарияси унинг амалиётига нисбатан кейинроқ пайдо бўлган деган фикрни илгари суради. Бу фикрни биз хам қўллаб-қувватлаймиз, чунки қадимги илк аккат-шумер луғатлари хам айнан таржима амалиётининг илк дебочаси хисобланади. Ғ.Хошимов яна таржимашунослик билан шуғулланган баъзи олимлар хақида гапириб ўтади. Олим бундан ташқари, транслятология, транслятолог, транслятор, транслятема, транслят, транслитерация, транскрипция, трансференция, трансформация каби таржима терминларининг изохини хам бериб ўтади $[2,22]$.

Ўзбек тилида сўз ясалиши, умуман янги сўз яратиш масалаларини ўрганиш ва у билан боғлиқ холда тилнинг ўзига хос қонунларини очиш, асосий луғат фондининг янги сўз яратилишида база эканлигини аниқлаш жуда хам мухим ва долзарб масалалардан биридир.

А.Хожиевнинг кўшма сўз компонентлари ўртасида грамматик муносабат мавжудлиги хақида билдирган фикрига тўлиқ қўшиламиз. Қўшма сўзларнинг сўз бирикмаси ва гапга нисбат қилиниши хам, бизнингча, илмий асослидир. Бироқ қўшма сўз компонентлари ўртасидаги грамматик муносабат жонли эмаслигини хам хисобга олмоқ лозим кўринади. Аввал эслатиб ўтганимиздек, бундай грамматик муносабат динамик характерга эга эмас, балки статик характерга эгадир.

Лингвокультурология - лингвистика ва маданиятшунослик ўртасида вужудга келган янги мустақил фан. У халқлар маданиятининг вужудга келиш тарихи ва унинг тилда акс этиш жихатларини ўрганади. Лингвокультурологиянинг ривожланиш даврини иккига бўлиш мумкин: биринчи давр - фаннинг вужудга келиш даври. Бу асосан В.Гумбольдт, Я.Гримм, А.А.Потебня, Э.Сэпиришларида ўз аксини топган. Иккинчи давр: лингвокультурологиянинг мустақил фан деб тан олинишидир. («Лингвокультурология» атамаси илк бор В.В.Воробьев, В.Н.ТелияваВ.А.Маслова ишларида қайд этилган). Энди миллий қадриятларга оид қўшма сўзларни таржима қилиш ва маъносини сақлаш йўллари хусусида мунозара юритсак. Миллий қадрият тушунчасига диссертация параграфларида қисман маълумот келтириб ўтилган бўлсада, биз ушбу тушунчага яна тўхталишни жоиз деб билдик. Миллий сўзи барчамизга маълум хар бир халқнинг ўзига тегишли анъана, урф-одатлар, яшаш тарзи, дунёқараши каби тушунчалар мажмуини англатади. Қадрият сўзи эса, Ўзбек тилининг изохли луғатида қуйидаги маъноларни англатишини кузатдик. Қадрият (арабча. -қиймат, ахамият; қимматбахо буюмлар; халқ бошлиғи) - воқеликдаги муайян ходисаларнинг умуминсоний, ижтимоий-ахлоқий, маданий, маънавий ахамиятини кўрсатиш учун қўлланиладиган тушунча. Инсон ва инсоният учун ахамиятли бўлган барча нарсалар, мас., эркинлик, тинчлик, адолат, маърифат, хақиқат, яхшилик, моддий ва маънавий бойликлар ва бошқалар қадрият хисобланади. Аммо ошкоралик дегани кимсанинг хохлаган пайтда қадриятларимизни оёқости қцлиши дегани эмас.[3, 207]. Демак, ўзбек халқи яратган моддий ва маънавий бойликлар, минг йиллардан буён инсонлар орасида яшаб келаётган анъана ва урф одатларни биз ўзбек халқининг миллий қадриятлари сифатида талқин этамиз. Қуйида эса Адхамжон Ашировнинг “Ўзбек халқининг қадимий эътиқод ва 
маросимлари"[2, 141] монографиясида учраган баъзи бир қадриятлар ва уларни англатувчи сўзлар, айнан қўшма сўзларни таржима хусусиятлари ва миллий қадриятлар маъносини сақлаш йўллари хақида фикр юритамиз. Ушбу китобда миллий қадриятлармиздан бири бўлган “куёвнавкар” сўзига дастлаб эътибор қаратамиз. Ушбу сўз синтактик жихатдан икки “куёв" ва "навкар" сўзларининг кўшилишидан хосил бўлади. Ушбу сўз иштирок этган қуйидаги гапга эътибор қаратамиз: Унинг нигохуи куёвнавкарлар ичидан Тўра акани топди(Ёшлик). Ушбу гап миллий қадриятни англатувчи куёвнавкар қўшма сўзи қатнашгани билан ақамиятлидир. Ушбу гап инглиз тилига қуйидагича таржима қилинади: She looked at groomsmen and found Tura aka among them. Куёвнавкар сўзи инглиз тилидаги groomsman сўзига эквивалент бўлади. Бу ерда биз Харвей томонидан миллий қадриятга оид сўзларни таржима қилиш учун таклиф этилган таржима усулларидан вазифавий эквивалент таржима муаммосини бартараф этади деб ўйлаймиз. Чунки, Ўзбек тили изохли луғатида куёвнавкар сўзининг "тўй маросимида куёв билан бирга бўлувчи жўралар" маъноси мавжуд. Oxford Advanced Learner's Dictionary луғатида эса groomsman сўзига қуйидагича таъриф берилган: a friend of the bridegroom at the wedding, who has special duties. Бундан куриниб турибдики, бу сўз икки тилда вазифаси жихатидан бир-бирига эквивалент бўла олади.

Тилимизда яна миллий қадриятни англатувчи белбоғ қўшма сўзи мавжуд бўлиб, бу сўзни таржима қилишда прагматик таржимага эришиш, миллий қадриятни таржима тилида хам сақлаб қолиш таржима жараёнида ўзига хос қийинчилик туғдиради. Белбоғ сўзи иштирок этган қуйидаги жумлага эътибор қаратсак. Нозим Зухранинг бошини аста силаб, ўз кўз ёшини белбоғи учига артди. Ушбу гап инглиз тилига қуйидагича таржима қилинади: Nozim caressed Zuhra's head slowly and rubbed tears with his belbog'.Ушбу гапда иштирок этган белбоғ сўзини юқорида олимлар томонидан таклиф этилган тасвирий эквивалент усулида таржима қилинди. Агар таржимон ушбу сўзни инглиз тилида эквивалент сифатида belt билан таржима қилса, миллий қадрият сақланиб қолинмайди. Чунки, белбоғ сўзи инглиз тилидаги beltcy̆зига эквивалент бўла олмайди. Belt ўзбек тилидаги камар сўзини англатиши мумкин. Вахолангки, камарни учи билан кўз ёшини артиб бўлмайди. Бу холатда таржимондан сўзнинг лексик-семантик ва лингвокультурологик хусусиятларини тўғри тушуниш талаб қилинади. Ўзбек тили изохли луғатида белбоғ сўзининг қуйидаги маънолари мавжуд: 1. Белга боғланадиган, тўртбурчак рўмол шаклидаги гулли ёки гулсиз, четлари тикилган мато парчаси қийик, қийиқча. 2. Умуман, белга белбоғ каби боғланадиган нарса. 3. Хар нарсанинг ўрта белидан ўтган фаразий чизиқ ёки халқа; экватор.Beltcy̆зининг эса Oxford Advanced Learner's Dictionary луғатида қуйидаги маънолари бор: 1 . Long narrow piece of leather, cloth, etc. that you wear around the waist. 2. A continuous band of material that moves round and is used to carry things along or to drive machinery. 3. An area with particular characteristics of where a particular group of people live. 4. An act of hitting smth./smb.hard. Демак, миллий қадрият маъносини англатувчи белбоғ кўшма сўзининг бош маъноси ЎТИЛдаги биринчи маъноси хисобланади. OSLD луғатидаги бунга яқин маъноси биринчи ва иккинчи маъноси хисобланиб, кўпроқ ўзбек тилидаги камар сўзига тўғри келади. Таржима жараёнида белбоғ сўзининг эквиваленти қилиб, Beltcy̆зининг олиниши таржимоннинг хатога йўл қўйиши ва миллий қадрият маъносини йўқотишига олиб келади. Бундай холларда таржимон descriptive equivalent (сўзга таржима тилида тавсиф бериш) усулидан фойдаланиши мақсадга мувофиқ бўлади. Яъни belbog(it is piece of material sewed in form of quadrangle kerchief and you wear around the waist).

Маданий бирликларни таржима қилиш жараёнида қуйидаги таржима трансформацияларидан фойдаланиш мақсадга мувофиқ бўлади: транслитерация, анъанавий эквивалент, бетарафлаштириш (вазифавий ёки изохланган эквивалент), сўзма-сўз таржима, мослаштириш, таркибий тахлил, ўчириб ташлаш, жуфтлик, стандартлаштирилган таржима, изохлаш, шарх, ва таснифлаш. 


\section{Адабиётлар:}

1. А.Аширов.Ўзбек халқининг қадимий эътиқод ва маросимлари.Тошкент:2017,270 б.

2.Ғ.М.Хошимов. К теории метаязыка транслятологии. “Таржиманинг лингвокогнитив, коммуникатив-прагматик ва лингвокультурологик аспектлари" Республика илмий-амалий анжумани материаллари тўплами. Андижон: Андижон нашриёт-матба. 2015. 21-23-бетлар.

3. Ўзбек тилининг изохли луғати. "Ўзбекистон миллий энциклопедияси" давлат илмий нашриёти. Тошкент, 2007. 3-жилд. 207-бет.

\section{“SHUM BOLA” ASARI LUG'AT TARKIBINING TARJIMADA AKS ETISHI}

\section{Halmuratov Izzatilla Ne'matullayevich O'zbekiston Davlat Jahon Tillari Universiteti magistr talabasi}

Annotation: This article discusses the difficulties of literary translation as well as vocabulary used in the translation of famous work "Shum bola" (" $A$ Naughty Boy") by Gafur Gulyam. The author analyses lexical, contextual and other problems occurring during the translation and recommends the ways of their solution. Particular attention is paid to linguistic-cultural aspects of the work.

\author{
Key words: \\ language \\ atmosphere, context, \\ lexical problems, \\ linguistic-cultural \\ aspects, tearoom.
}

Tarjima jarayoni nihoyatda mushkul vazifa hisoblanadi.Tarjimon hamma vaqt so'z bilan ish ko'radi. Ikki yoki bir necha tilning muhiti va so'zlari dunyosida ham ijodkor, ham tadqiqotchi lingvist va stilist sifatida harakat qiladi. Tarjimon original asarning mazmuni va mundarijasiga ko'ra qo'llangan so'zlar, jumlalar, gaplarning ma'nolarini chiqaradi va ularni asarning umumiy mundarijasi, uslubi, shakliga moslaydi, muvofiqlashtiradi.

Tarjimon jumla va gapni tashkil etuvchi alohida so'zlarning ma'nolarini faqat va faqat kontekstga va uning oqimiga qarabgina chiqaradi, so'zning ma'nosini jumlaga, jumlaning ma'nosini gapga, gapning ma'nosini alohida tugallangan parchaga va parchaning ma'nosini asarning butun mundarijasi, shakli hamda uslubga moslaydi. Zero, so'zning, jumlaning maqsadi, vazifasi, undan muallif kuzatgan mazmun faqat kontekstda to'la ochiladi [1,122].Aynan shularni inobatga oladigan bo'lsak, badiiy asarlarni tarjima qilish jarayonida tarjimon leksik muammolarga ko'proq duch keladi. Chunki bir tilda mavjud bo'lgan terminlar boshqa tilda umuman bo'lmasligi mumkin, bu esa o'z navbatida tarjimondan yuksak mahorat va bilimni talab qiladi.

Ikki til xususiyatlarini bilish zamirida asarni har tomonlama o'rganish, uning lug'ati va realiylari ustida ishlash tarjimon uchun juda muhim va bu uni ma'lum darajada olim va tadqiqotchi bo'lishini ham taqozo etadi. O'zbek tilida "til topish" degan ko'p ma'noli ibora bor. Birovning qulf-kaliti ochilmagan yuragiga yo'l topishni aytishadi. Ikki odamning hayotda biror ish, muammo ustida bir-birini yaxshi tushunishi, bilishi va shunga ko'ra ish ko'rishi ham shu ibora bilan ifodalanadi. U o'zaro kelishish, ahd-paymon ma'nolarini ham ifodalaydi.

Tarjima qilinadigan muallif va uning asari bilan tarjimon o'rtasida ham shunday til topishish bo'lishi zarur. Bunda til topish deganda muallifning o'ziga xosliklarini va muayyan asaming badiiy xususiyatlarini teran anglash va shunga yarasha jarayonni tashkil etishni tushunamiz $[3,73]$. Tarjima qilinadigan muallif va uning asarini tarjimon sevgandagina, uning o'z o'quvchisiga katta ma'naviy foyda keltirishini bilgandagina til topish juda katta ijodiy foyda keltiradi.

Tarjimaning leksik muammolarini hat etishda ikki tilli lug'atlar ma'lum jihatdan ahamiyati katta hisoblanadi.Biroq odatda lug'atlarda so'z ma'nosining muqobillarigina beriladi.Tarjima lug'ati qanchalik mukammal bo'lmasin.unda so'zlaming barcha ma'nolari yoki ma'no nozikliklarini qamrab olishning iloji yo'q, chunki lug'at ikki til tizimi unsurlari bilan ish ko'radi $[2,5]$.Tarjima uchun til tizimlari emas, balki nutq, aniqroq qilib aytadigan 
bo'lsak, nutq mahsuli bo'lmish matn muhimroqdir.Tarjiima jarayonida tarjimon ko'p ma'noli so'zning qaysi ma'nosi qo'llanilganligini kontekst asosida o'zi aniqlamog'i lozim.

G'afur G'ulomning "Shum bola" asari ingliz tiliga Ilhom To'xtasinov va Ulug'bek Yo'ldoshev tomonidan tarjima qilingan. Asarning ingliz tilidagi tarjimasini boshidan oxirigacha o'qib chiqdim.0'qish jarayonida tarjimadagi ayrim leksik birliklar, atamalarni o'zbek tilidan ingliz tiliga tarjima qilingandagi o'ziga xosliklarga duch keldim.Ya'ni bunda asosiy xususiyat ikki til madaniyatining bir-biridan tubdan farq qilishi, o'zbek tilidagi o'ziga xos milliylikni, turmush tarzini, an'analarini ifodalovchi realiyalar mavjudligi, o'zbek xalqi dunyoqarashining ingliz xalqidan mutlaqo o'zgachaligi hisoblanadi.Aynan shu kabi jihatlarni inobatga olgan holda tarjima jarayonida asar lug'at tarkibining tarjimada qay tarzda aks ettirilganini tahlil qilib chiqishga jazm qildik. "Shum bola" kitobining I bo'limi boshlanishida dastlabki gaplardan biriga e'tibor qaratsak:

"Qaymoq bozorining burilishida, Mahkamaning boshida Ilhom samovarchining kattakon choyxonasi bo'lib, unda grammofon chalinadi."

Ilhom To'xtasinov va Ulug'bek Yo'ldoshev tomonidan tarjima qilingan "A Naughty Boy" kitobagi ingliz tilidagi tarjimasi:

"At the corner of the sour-milk market, next to the office, there is a big teahouse of Ilhom samovarmaker and a gramophone is playing there all the time."

Ushbu gapda yozuvchi G'afur G'ulom "Ilhom samovarchi” deb bergan qahramonni tarjimonlar o'z tarjimasida "Ilhom samovarmaker" deb keltirishgan.0'zbek adibi bu o'rinda "samovarchi" so'zini "choyxona egasi, choyxonani boshqaruvchi” ma'nosida bergan, ammo tarjimon ingliz tilida "samovarmaker" deb "samovar yasovchi" ma'nosida tarjima qilgan. Ya'ni bu tarjima orqali o'zbek tilidagi gapning asl ma'nosi o'zgargan, aslida "samovarchi" so'zini "the owner of the teahouse" deb tarjima qilinganda ko'proq maqsadga muvofiq bo'lardi. Bundan tashqari yana bir jumlaga e'tibor qarataylik: "a gramophone is playing there all the time". Bu tarjima orqali biz u yerda tinimsiz ertalabdan kechgacha grammafonning qo'yilishi, uni tinglashlarini tushunamiz, ammo asarda bunaqa mazmun ko'rsatilmagan, yozuvchi shunchaki choyxonada grammafon borligi, ayrim paytlarda uni tinglashlarini yozgan, ammo hamma vaqt tinimsiz qo'yiladi deyilmagan.Bu ham tarjimadagi qaysidir ma'nodagi kamchilikni ko'rsatadi.Va aynan ushbu o'rinda shuni alohida ta'kidlashimiz mumkinki, bu yerda muallif, ya'ni G'afur G'ulomning o'ziga xos talqinini ko'rstamiz, ya'ni u "grammafon chalinadi" deb yozgan. Grammafon chalinmaydi, u plastinkadagi yozuvni ovoz qilib baland chiqarib beruvchi asbob, mexanizmdir.Shuning uchun ingliz tilida "to play" fe'li, rus tilida esa "проигрывать" fe'li ishlatilgan.Ammo aslo "chalinadi" fe'li emas.Shuningdek, "choyxona", "samovar" kabi so'zlar linguokulturologik xususiyatga ega bo'lib, aynan o'zbek xalqigagina tegishli hisoblanadi.Tarjimada "samovar" so'zi transliteratsiya usuli bilan xuddi shu ko'rinishda berilgan, "choyxona" so'zi esa tarjima qilingan.Ya'ni tarjima orqali asliyatdagi pragmatik xususiyat deyarli saqlab qolingan.

"Shum bola" kitobining 3-betidagi yana bir gapga e'tiborimizni qaratsak.

"Turli-tuman plastinkalar orqali To'ychi hofiz, Hamroqul qori, Hoji Abdulaziz va Farg'ona yallachi xotinlari ketma-ket maqomlar, yallalar, ashulalar aytadi. Choyxonada joy yetishmaydi."

"On different disks, Tuychi singer, Hamrakul, Hoji Abdulaziz, and woman singers from Fergana sing their songs. The tearoom is full of people."

Bu gapdagi tarjimada ko'rishimiz mumkinki, Hamroqul qori tarjimada "qori" so'zi tashlab ketilgan, To'ychi hofiz - "To'ychi singers" deya tarjima qilingan, lekin o'zbek tilida hofizlar deyilmagan, balki birgina hofiz ismi keltirilgan xolos, tarjimada esa "singers" bo'lib ko'plikda berilgan va aynan "singer" so'zi o'zbek tilidagi "hofiz" ma'nosini butunlay ko'rsatib bera olmaydi. Bundan tashqari "woman singers from Fergana" tarjimasi "Farg'ona yallachi xotinlari" birikmasi o'rnida keltirilgan. Bunda ham ko'rishimiz mumkinki, "singers" so'zi "yallachi" ma'nosida berilgan, umuman olganda asarning ingliz tilidagi tarjimasini o'qigan 
kitobxon aynan asardagi o'sha davr va muhitni to'liq his qila olmaydi, yozuvchining ko'rsatmoqchi bo'lgan manzarasini asl holida tasavvur qila olishi nihoyatda mushkul deb o'ylayman. Va yana ushbu gap tarjimasida "maqomlar, yallalar, ashulalar" kabi so'zlar birgina "songs" bilan berilgan. Tarjimonlar gapni aslicha korsatib bera olishmagan, ya'niki asarning o'zbek tilidagi lug'at tarkibi ingliz tilida to'laligicha o'z aksini topa olmagan. “Choyxonada joy yetishmaydi" jumlasi tarjimada "the tearoom is full of people" deb berilgan.Biz bilamizki, "full of" iborasi "to'la, to'liq" degan ma'noni ifodalaydi, lekin bu gapni tarjimada "the teahouse is overcrowded" deb berilganda o'zbek tilidagi gap ma'nosini ko'proq ochib bergan bo'lardi.

"Shum bola" asari leksikasining tarjimada qay tarzda aks etganini yana keying gaplar misolida tahlil qilishda davom etamiz.

"Uzun rasta, Juhud rasta, attorlik va boshqa rastalarning boyvachchalari savdodan bo'sh vaqtlarida bu choyxonaga yig'ilib mexmonxonalardek o'rtada katta barkashlardan qand-qurs, pista-bodom, murabbo-nisholda, obi non, shirmoy nonlar bilan shamaloq bezatilgan dasturxon atrofida chaqchaqlashib o'tirishardi. Ba'zi boyvachchalarning dasturxonida qorniga qaldirg'och surati solingan, ustiga poxoldan to'r to'qilgan konyaklar ham ko'rinar edi."(3-bet "Shum bola")

"The rich of long rows, haberdashery rows and other rows gather there at the table served with lumps of sugar, nuts, jam, hot-bread and oil-bread, and they are having endless chattering. There are also bottles of cognacs on the tables of some rich men." (5-bet "A Naughty Boy")

Birinchi navbatda jumlaning hajmiga e'tibor beradigan bo'lsak, ko'rinib turibdiki, ingliz tilidagi tarjimasi o'zbek tilidagidan deyarli 2 baravar qisqa.Aynan shu jumla tarjimasini o'qigan kitobxon tarjima jarayonida ayrim so'zlarning butunlay tushirib qoldirilganligini sezishi unchalik ham qiyin emas.Masalan, birinchi gapdagi "Juhud rasta" birikmasi tarjimada gapga kiritilmagan.Bundan tashqari boyvachchalarning savdodan bo'sh paytlarida choyxonaga yig'ilishlari ko'rsatilmagan. "Pista-bodom" shunchaki "nuts" deb, "murabbonisholda" esa birgina "jam" bilan ifodalangan.To'g'ri, balki "nisholda" ingliz madaniyatida mavjud bo'lmaganligi sababli ularning lug'atida bunday so'z yo'qligi uning tarjima qilinmay qoldirilganiga asos bo'lar, ammo uni tarjimada izoh bilan birga berilishi o'zbek madaniyatini, yashash tarzini yorqinroq, aniqroq aks ettirgan bo'lardi. "Shamaloq bezatilgan dasturxon atrofida" jumlasi tarjimada "at the tables served with" deya keltirilgan. Bunda ham ko'rishimiz mumkinki, o'zbek tili lug'atining qanchalar boyligi va aynan shundan adib mahorat bilan foydalanganligi tahsinga loyiq. Keyingi gapdagi “qorniga qaldirg'och surati solingan, ustiga poxoldan to'r to'qilgan konyaklar" esa tarjimada deyarli to'liq tasvirlanmagan, tarjimonlar shunchaki osongina "bottles of cognacs" deb tarjima qilib qo'ya qolishgan xolos. Asardagi yozuvchi tasvirlamoqchi bo'lgan choyxona manzarasi, undagi muhit, o'zbek xalqi dasturxonidagi turli-tuman noz-ne'matlaru o'ziga xos tashqi ko'rinishi bilan ajralib turadigan konyaklar ingliz tilida yuksak mahorat bilan yoritib berilmagan deb o'ylayman.

Umuman olganda, "Shum bola" qissasini boshidan oxirigacha o'qib chiqib, uni ingliz tilidagi tarjimasi bilan solishtirsak, tarjimadagi bu kabi leksik kamchiliklarni, o'zbek tili lug'atidagi ayrim ingliz tilida ekvivalenti yo'q bo'lgan so'zlarni tarjimada aks ettirilmay tushirib qoldirilganiga ko'p jumlalarda duch kelishimiz mumkin.Shuning uchun badiiy tarjima muammolari bugungi kungacha tarjimashunoslikning eng dolzarb muammolari sifatida ko'rilmoqda.

\section{Adabiyotlar :}

1. G'ofurov, O.Mo'minov, N.Qambarov. Tarjima nazariyasi. - Toshkent: "Tafakkur bo'stoni", 2012, 122123-bet.

2. Newmark P. A Textbook of Translation. - London :Prentice Hall, 1988/1995. 234P.

3. Саломов Ғ. Таржима назариясига кириш. -Т.: Ўқитувчи, 1978. 236 б. 
FRANSUZCHA BADIIY TARJIMADA SINONIMLARNING O'RNI

(Antuan de Sent-Ekzyuperining „Kichkina shahzoda” falsafiy ertagi misolida)

\section{Suvonov Behruz \\ Samarqand davlat chet tillar instituti talabasi Ilmiy rahbar: f.f.n., dots. Suvonova N.N. Email:suvonov@samdchti.uz}

Annotation: In this article, it is focused on the synonymes and the semantic and pragmatic particularities of synonymes used in the literature works of Antoine de Saint-Exupéry „, Le petit Prince”(,The little Prince"). Here it is learned that the synonymes words in French linguistics play an important roles to discover the ability of expressions andit is used some examples from the descriptionpictures of the personages in the work of French literature. So, to be more precise to learn in detail the theme in question, it is focused mainly on the adjectives synonymes words.
Key Words: synonymes, pragmaticism, semantic words, word-analyse, sentenceanalyse, pragmalinguistics, description words, absolute synonymes, partial synonymes, character of words and forms, literature speech.

Sinonimlar, yunoncha - synonymos- bir nomli - bir umumiy ma'noga ega bo'lgan \{denotativ ma'nosi bir xil\}, qo'shimcha \{konnotativ\} ma'nosi \{ekspressiv, uslubiy va boshqa munosabat kabilarni ifodalovchi xususiyatlari\} bilan farqlanadigan til birliklari - so'z, ibora, sintaktik birlik va boshqalar. Masalan boshqatdan, qayta, qaytadan, yangidan, yana, takror so'zlari sinonim so'zlar hisoblanadi. Til birliklarining bir xil ma'noga ega bo'lishi sinonimiya hodisasi deyiladi. Bu hodisa qanday til birliklariga xosliligiga ko'ra lug'aviy sinonimiya, frazeologik sinonimiya kabilarga bo'linadi. O'zaro sinonim bo'lgan so'zlar guruhi sinonimlar qatori deyiladi ${ }^{1}$. Sinonimlar qatori ikki va undan ortiq so'zlardan tashkil topadi. Masalan , buloq-chashma sinonimlar qatori ikki so'zdan, yuz- aft- bashara-bet sinonimlar qatori esa ko'p so'zdan tuzilgan . Ko'p ma'noli so'zlar muayyan ma'nosi yoki ma'nolari bilan bir yoki birdan ortiq sinonimlar qatoriga kirishi mumkin. Masalan, bitirmoq so'zi bir ma'nosi bilan tugatmoq, tugallamoq, tamomlamoq... so'zlari qatoriga, boshqa ma'nosi bilan ado qilmoq, yo'qotmoq, yo'q qilmoq so'zlari qatoriga kiradi. Fransuz linvistik adabiyotlarida sinonimlar bir xil ma'noli so'zlar yoki bir-biriga yaqin ma'noli so'zlar sifatida ta'riflanadi. Misol uchun, ushbu mavzuda qator ilmiy izlanishlar olib borgan fransuz tilshunosi M. Bréal fikriga qaraymiz: La synonymie est une phénomène précaire et provisiore, de courte durée qui se détruit infaillaiblement du fait que les mots-synonymes sont sujets à l'évolution sémantique et acquièrent, par conséquent, des acceptions distinctes ${ }^{2}$. Tarjima aytib turganidek, sinonimlar tilshunoslikda semantik evolutsiyaning mahsuli bo'lib, ular o'zaro yaqin ma'nodagi so'zlar majmuyida aks etadi.

Har bir badiiy asar o'ziga xos va takrorlanmas sujet, obraz va personajlarga ega. Misol uchun, XX asrning eng mashhur ertak-qissalaridan biri hisoblanuvchi fransuz uchuvchi-adibi Antuan de Sent-Ekzyuperining „Kichkina shahzoda” falsafiy ertagi hisoblanadi. “Kichkina shahzoda" - allegorik ertak, Antuan de Sent-Ekzyuperining eng mashhur asari. Ertak koinotdagi, shu jumladan, Yerdagi turli sayyoralarni ziyorat qilgan Kichkina shahzoda haqida hikoya qiladi. U yolg'izlik, do'stlik, sevgi va yo'qotish mavzulariga bag'ishlangan.

Antuan de Sent-Ekzyuperining „Kichkina shahzoda” ertagida ko'plab sifat sinonimlarining boshqa so'z turkumlari bilan ma'nodoshligini ko'rishimiz mumkin, bu esa badiiy asarning yengil va quvnoq o'qilishi uchun ishlatilagan bo'lsa, ba'zi joylarida jarayon va holatni yanada to'kisroq ifoda etish uchun qo'llanilgan. Bu kabi sinonimlarning ishaltilishi 
ayniqsa badiiy asar personajlari va obrazlarini yaratishda juda imkoniyatlar ochib beradi. Misol uchun, le roi yoki le géograhpe obrazlarini yaratishda bu usuldan unumli foydalanilgan: La première était habitée par un roi. Le roi siégeait, habillé de pourpre et d'hermine, sur un trône très simple et cependant majestueux ( $p$ 41) ... Car le roi tenait essentiellement à ce que son autorité fût respectée. Il ne tolérait pas la désobéissance. C'était un monarque absolu. Mais, comme il était très bon, il donnait des ordres raisonnables. ( $p$ 43) ... Car non seulement c'était un monarque absolu mais c'était un monarque universel. ( $p$ 44)

$\mathrm{Bu}$ yerda universel- absolu, majestueux-raisonnableskabi birikmalarni ham kuzatish mumkin. Demak, sinonimlarning badiiy adabiyotda pragmatik qo'llanilishi nafaqat so'z turkumlari doirasida, balki so'zlarning ma'no ottenkalariga ham bog'liq. Zamonaviy fransuz tili mutaxassislari sinonimiya hodisasiga quyidagi fikr bildiradi:

Des mots peuvent être définis comme synonymes lorsqu'ils peuvent être remplacés les uns par les autres sans changer du sens. Ces mots peuvent avoir plusieurs significations différentes (NB : cette phrase contredit la précédente, car si la signification est différente, alors le sens change).

- Les mots peuvent montrer des intensités différentes (ex. : triste < déprimé < bouleversé)

- Les mots aussi présentent des connotations différentes (individuelles ou collectives). Certaines personnes peuvent penser que les mots sont synonymes, mais d'autres ne pas penser la même chose

L'usage des synonymes permet donc d'éviter les répétitions. Cependant, il peut aussi provoquer des glissements de significations dommageables pour la compréhension ${ }^{1}$. La synonymie est un rapport de similarité sémantique entre des mots ou des expressions d'une même langue. La similarité sémantique indique qu'ils ont des significations très semblables. Des termes liés par synonymie sont des synonymes. Synonyme et équivalent. L'équivalent remplace un mot par une locution qui signifie la même chose ; par exemple quand on met la définition au lieu du terme lui-même. Le synonyme offre des nuances d'acception qui le distinguent plus ou moins d'un mot à signification voisine. ${ }^{2}$

Xulosa sifatida aytish mumkinki, sinonimlarning leksik-semantik xususiyatlari ularning turli shakl va ma'no ottenkalariga ega bo'lishi bilan xarakterlanadi. Shuningdek, hozirgi kunda sinonimlar va variantdosh so'zlar o'rtasida ko' plab o'shash xususiyatlar kashf etilmoqda. Ular o'rtasidagi farqlarni L. G. Barlas quyidagicha izohlaydi: variantlilik bir xil, sinonimiya har xil til birliklariga xos xususiyat. Variantlar deyilganda, shakliy jihatdan bir oz farq qiladigan bir til birligining turli ko'rinishlari tushuniladi. Ular bir so'z, bir so'z shakli yoki qurilishini tashkil etgani uchun ham leksik va grammatik ma'nolarda farqlar bo'lmasligi kerak. Sinonimlar esa ma'nolari bir-birlariga yaqin bo'lgan turli so'zlar, so'z shakllari, qurilmalardir.

\section{Adabiyotlar:}

1. Sh.M.Mirziyoyev Erkin va farovon, demokratik O'zbekiston davlatini birgalikda barpo etamiz. O’zbekiston Respublikasi Prezidenti lavozimiga kirishish tantanali marosimiga bag'ishlangan Oliy Majlis palatalarining qo'shma majlisidagi nutq

2. Safarov Sh Pragmalingvistika- Toshkent 2008. 318 bet

3. Suvonova N.N Matn tahlili(grammatik va leksik). Samarqand 2010

4. O'zbek tilidan ma'ruzalar to'plami" N.Erkaboyeva.103 bet. T..2017

5. M.Bréal. Essai de sémantique(chap. , la loi de la répartition”), 1997

6. Revue Communication et traces numériques, Presses universitaires Rouen Le Havre.

7. A. de Saint-Exupéry Le Petit Prince. 1943. Novembre 2008 - Élaboration de ce livre électronique : Les membres de Ebooks libres et gratuits qui ont participé à l'élaboration de ce livre, sont : PatriceC, Coolmicro et Fred 


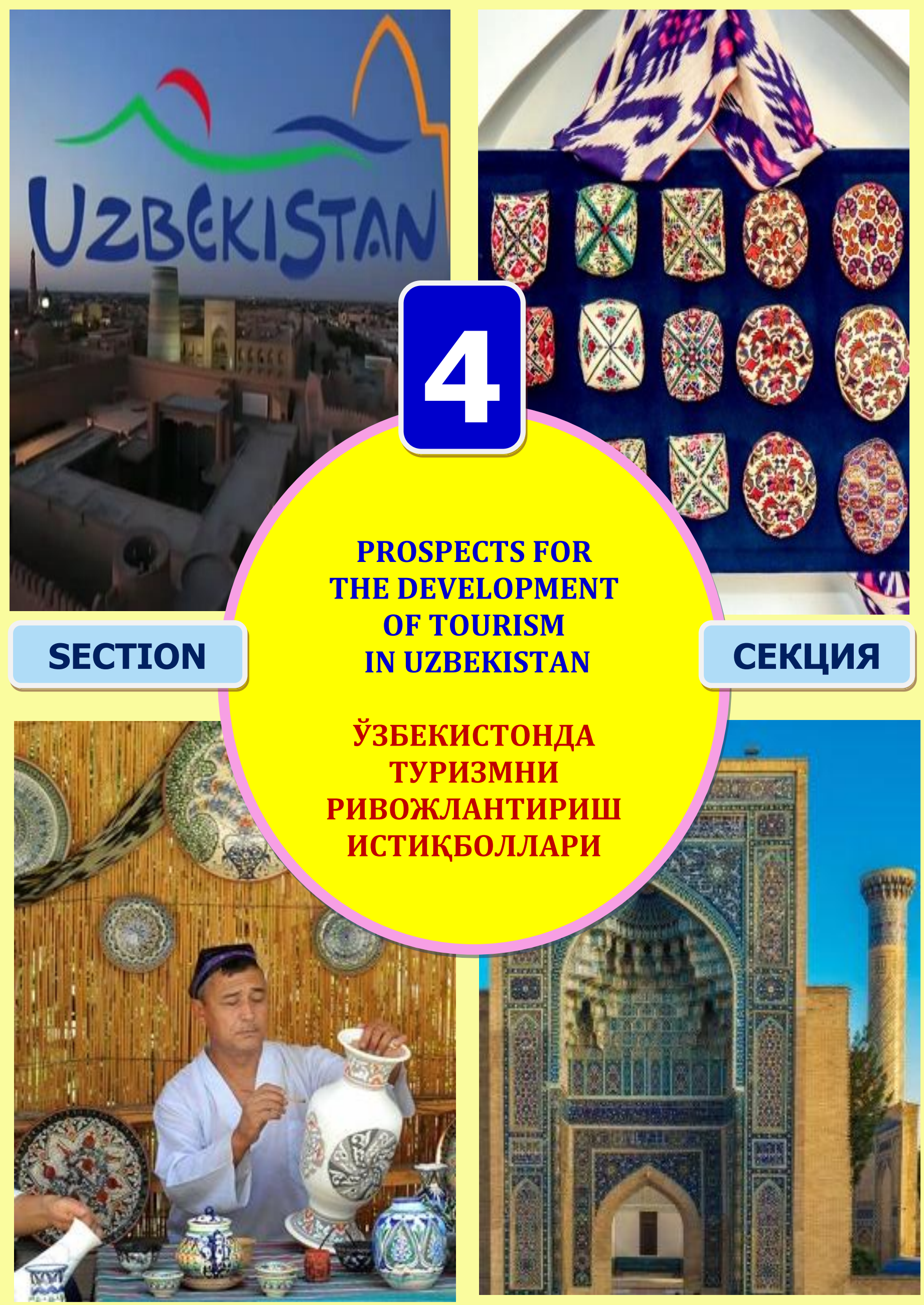


PARTICIPANTS :

1. Carlos Uriarte Sánchez Profesor de Derecho de la Universidad Rey Juan Carlos, Madrid, España

2. Холиқова Рахбар Эргашевна Тарих фанлари доктори, профессор Тошкент давлат техника универ.

3. Hubert Boone

Musicien, membre du groupe Limbrant, Belgique

4. Sabirov Kodir Head of International Affairs of Bukhara Branch of Tashkent institute of Irrigation and agricultural mechanization engineers.

5. Алимова Машхура Иқтисод банлари доктори, доцент, "Ипак Йўли” Туризм халқаро Университети проректори

6. Аллаёров Р.А. Самарқанд Иқтисодиёт ва Сервис Институти таянч докторанти

7. Исмоилов Салохиддин Исмоилович Филология фанлари номзоди, доцент Самарқанд давлат чет тиллар институти

8. Сувонова Нигорабону

Низомиддиновна Филология фанлари номзоди, Сам ДЧТИ доценти

9. Ўринбоева Мўътабар Якубовна, Самарқанд вилоят ўлкашунослик музейи бўлим мудири

10. Ражабов Хусниддин Жахон иқтисодиёти ва дипломатия университети докторанти

11. Хакимов Эркин Тўйчиевич Фарғона Давлат Университети доценти

\section{ИШТИРОКЧИЛАР:}

12. Мирзарахимов Бахтиёр Хошимович Фарғона Давлат Университети ўқитувчиси

13. Nasimov Ulug'bek Orif o'g'li Samarqand Davlat Universiteti o'qituvchisi

14. Умаров Тохир Облакулович “Ипак йўли" туризм халқаро универ. стажёр-тадқиқотчиси

15. Muqumov Toshqobil

SamDCHTI o'qituvchisi

16. Rakhimova Sadokat Makhmudovna Urgench state UniversityTourism and economy faculty, PhD student

17. Eshboyeva Tursuntosh Soxatmamatovna Samarqand davlat chet tillar instituti magistri

18. Xayrullayeva Aziza SamDCHTI talabasi

19. Islamova Ozoda SamDCHTI talabasi

20. Saidova Shaxnozabonu Shaxobiddin qizi Samarqand viloyat 54-maktab iqtidorli o'quvchisi

21. Mustofoqulov Farhod SamDCHTI o'qituvchisi

22. Burxonov Utkir Samarqand davlat chet tillar instituti o'qituvchisi

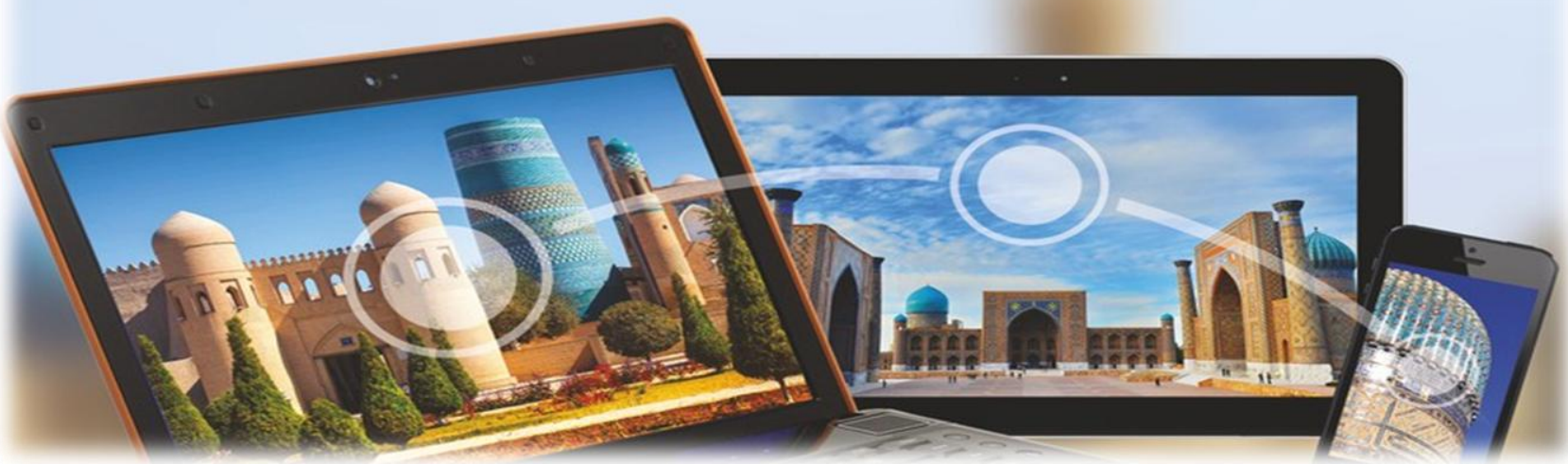


RETOS Y OPORTUNIDADES DE UZBEKISTÁN DENTRO DEL SECTOR TURÍSTICO: CALIDAD, SOSTENIBILIDAD Y DERECHO

\section{Carlos Uriarte Sánchez \\ Profesor de Derecho de la \\ Universidad Rey Juan Carlos, \\ Madrid, España \\ Carlos.uriarte@urjc.es}

Es para mí un privilegio poder participar en tan interesante congreso en la ciudad de Samarcanda, que he podido visitar en dos ocasiones, en 2018, durante una conferencia de la OSCE y en 2019 como observador internacional independiente durante las últimas elecciones parlamentarias. En esta ocasión, no ha podido ser presencialmente como hubiera sido mi deseo debido a las restricciones que vivimos para los desplazamientos debido a la pandemia mundial del Covid-19. No obstante, debo de felicitar a las autoridades uzbekas por el excelente trabajo que han desarrollado en la gestión de esta crisis sanitaria mundial sin precedentes donde Uzbekistán ha demostrado ser un ejemplo de contención de la pandemia para el resto del mundo.

1) LA VISIÓN DE UZBEKISTÁN DESDE EUROPA: LA EXPERIENCIA ESPAÑOLA

Muchas veces los europeos no sabemos situar Uzbekistán en un mapa. Sabemos que fue una antigua república socialista de la Unión Soviética y poco más. Sin embargo, cuando profundizamos un poco más en este maravilloso país nos damos cuenta que está situado en un cruce de caminos entre Oriente y Occidente; al oeste: el mar Caspio, Azerbaiyán y Turquía; al norte: Kazajistán y Rusia; el este: China; y al sur y sur este: Pakistán y la India. Dentro de los denominados 5 "tanes” del Asia Central es el centro de todos ellos: Kazajistán (al norte), Turkmenistán (al sur) y Tayikistán y Kirguistán al este.

La Ruta de la Seda, quizá es lo primero que viene a nuestra mente cuando hablamos sobre Uzbekistán, porque ciudades como Samarcanda (2750 años), Bujará (más de 2500 años) y Jiva (más de 2000 años) eran los cruces más importantes en la Ruta de la Seda.

A lo largo de la historia de Uzbekistán ocurrieron muchos acontecimientos importantes que influyeron y que han dejado en la actualidad tienen una gran influencia y reflejo: el territorio de Uzbekistán formaba parte de antiguas y eminentes civilizaciones, como Corasmia y Sogdiana. Aquí llegaron los imperios poderosos como los de Alejandro Magno, Chingishan, o el Gran Tamerlán. Aquí se construyeron grandes maravillas de la arquitectura que nos sorprenden hasta hoy en día por su perfección y belleza y que pueden visitar los turistas en la actualidad. Uzbekistán fue además territorio un territorio que ha dado lugar a grandes científicos y filósofos

He tenido la oportunidad de viajar tres veces al Uzbekistán, conocer Tashkent, Samarcanda y Bujará. Viajar de Tashkent a Samarcanda y a Bujará en el tren de alta velocidad Afrosiyob,tecnología española de la empresa Talgo. Un tren de alta velocidad puntual, seguro y rápido. En la actualidad se está construyendo el tramo Bujará-Jiva.

Viajando a Uzbekistán tendrá la oportunidad de adentrarse en un mundo de leyendas y cuentos de "Las mil y una noches", descubrirán la historia y los misterios de los monumentos de las ciudades declaradas Patrimonio de la Humanidad por la UNESCO, degustarán los variados y deliciosos platos de la gastronomía uzbeka, como su plato nacional "el plov" (la paella uzbeka) y sentirán los aromas de las especias de la Ruta de la Seda. Escucharán los sonidos de los bailes nacionales y el jaleo de los mercados orientales. Conocerán la artesanía local visitando los talleres de telas de seda y algodón, cerámica, tallado en madera, etc. 
Uzbekistán se presenta para el europeo como un país fascinante, distinto, diverso y enriquecedor, que provoca que la visita de cualquier europeo nos haga remontarnos a los tiempos del gran conquistador de todo el Asia Central, el Gran Kan Emir Timur, conocido como Tamerlán y del embajador español Ruy González de Clavijo.

En la actualidad Uzbekistán cuenta con los siguientes lugares declarados como Patrimonio de la Humanidad por la UNESCO: Itchan Kala, en la provincia de Corasmia, ciudadela del antiguo oasis de Jiva, última etapa de las caravanas antes de empezar la travesía del desierto rumbo a Irán; el centro histórico de Bujará, situada en la Ruta de la Seda y con más de 2000 años de antigüedad. Es el ejemplo más completo de ciudad medieval existente en el Asia Central y su tejido urbano primigenio se ha conservado intacto en su mayor parte. Posee numerosos monumentos, entre los que destacan la célebre tumba de Ismail Samani, obra maestra dela arquitectura musulmana del siglo $\mathrm{X}$, y varias madrasas del siglo XVII; el centro histórico de Shakhrisyabz; la ciudad de Samarcanda, fundada con el nombre de de Afrasyab, alcanzó su apogeo en los siglos XIV y XV bajo los timúridas. Entre sus principales monumentos destacan la mezquita y las madrazas del Registán, la mezquita Bibi-Khanum, los conjuntos arquitectónicos de Shah i-Zinda y Gur i-Emir, y el observatorio de Ulugh-Beg; y el Tien Shan occidental.

Además, Uzbekistán posee seis elementos en la lista del Patrimonio Mundial Inmaterial como son el espacio cultural del distrito Boysun; la música shashmagom; el kata ashula o "gran canto"; el novruz o Festividad del Año Nuevo; el askiya, arte oratorio jocoso; la tradición y cultural del palov.

Así mismo, la sociedad uzbeka se destaca por su hospitalidad, su tolerancia religiosa, sus valores familares, que hacen que todo europeo se sienta en Uzbekistán seguro y como en su casa. Si quieres entrar en conversación con uzbeko es sencillo. Simplemente debes de preguntarle por su familia y él te preguntara por la tuya.

\section{2) POSIBILIDADES DE COLABORACIÓN EN EL ÁMBITO ACADÉMICO, CIENTÍFICO Y UNIVERSITARIO ENTRE ESPAÑA Y UZBEKISTÁN.}

Uzbekistán ha mostrado en numerosas ocasiones su voluntad de colaborar en los campos de la educación superior universitaria con España y otros países europeos. En este sentido, la parte uzbeka está interesada en implementar programas conjuntos, crear facultades conjuntas en Uzbekistán con España y otros países europeos y abrir sucursales de las universidades españolas en Uzbekistán en los campos de la arquitectura, la medicina, las tecnologías de la información y la comunicación, tecnologías para el procesamiento de productos agrícolas y otras áreas técnicas.

Cuando un español y un europeo viaja a Uzbekistán lo hace porque sabe que el país es distinto, seguro y ofrece unos paisajes y monumentos que son una joya en el mundo islámico de los que poder disfrutar en un marco de libertad, tolerancia y seguridad. Pero el español también demanda calidad. Los españoles y europeos somos afortunados por pertenecer a partes del mundo prósperas y por tanto, es importante, que Uzbekistán haga un esfuerzo en lograr la calidad y la excelencia en dicho sector si quiere ser líder en el mismo no sólo en el Asia Central sino como centro turístico mundial. Cómo conseguirlo:

- Formando a buenos profesionales que vayan a desarrollar trabajos en dicho sector: no basta con ser acogedor, sino que se debe ofrecer un servicio de calidad. El personal ha de estar bien formado tanto a nivel de dirección, por ejemplo, en la gestión de un hotel como a nivel de servicio de atención al huésped, por ejemplo, en el campo de la hostelería (los cocineros y camareros deben de estar bien formados).

- Haciendo un esfuerzo para que los profesionales del sector sepan lenguas extranjeras: como mínimo deben de saber inglés y si es posible otras como español, francés o alemán. Posiblemente de todos los turistas, el turista europeo sea el más exigente. 
- Estableciendo unos estudios integrales de turismo generales con sus respectivas especialidades a nivel universitario. Así como, formaciones profesionales de calidad como por ejemplo en el campo de la restauración.

- Favoreciendo la conectividad área con los países que aportan mayor número de turistas al país.

- Implementando un marco legal en el campo del turismo que aparte de establecer un marco regulador a los operadores del sector tanto nacionales como internacionales, ofrezca a los turistas seguridad jurídica como consumidor (creando por ejemplo sellos de calidad para establecimientos que hayan recibido una supervisión por parte del gobierno y que cumplen unos estándares de calidad internacionales, la creación de un portal del turista donde pueda llevar a cabo quejas, la facilitación de un sistema de arreglo de controversias mediante arbitraje como el que ofrece en España "Confianza on-line o establece la Directiva Europea de Derecho de los Consumidores ...

- Fomentando que el sector turístico contribuya a la cohesión social del país y a la distribución de la riqueza, haciendo del mismo, en elemento clave en la vertebración de Uzbekistán por ejemplo en los campos del transporte, las infraestructuras y las nuevas tecnologías que redunden no sólo en el turista extranjero sino en toda la población uzbeka en su conjunto.

- Garantizando que la responsabilidad y la sostenibilidad sean los ejes vertebradores de la industria turística. Unos servicios que deben de ser de calidad para el visitante, pero ante todo deben contribuir a que la característica del sector sea la auto exigencia y la continua búsqueda de la excelencia.

En resumen, Uzbekistán posee las condiciones necesarias para que la industria turística sea uno de los sectores fundamentales en el desarrollo del país desde un punto de vista económico y social. Para ello, es importante que Uzbekistán aprenda de la práctica de otros países turístico en el mundo. Sus monumentos históricos, su rica historia, sus paisajes, su gente, hacen que este sector tenga todavía mucho más potencial y ser un elemento de desarrollo, cohesión y sostenibilidad de todo el país.

Es importante que Uzbekistán se dote de la legislación más avanzada del mundo en el sector turístico y en los derechos de los consumidores, pues para que el turismo se desarrolle la confianza y la seguridad por parte del turista, del consumidor son fundamentales.

Espero que estas reflexiones contribuyan a mejorar la cooperación entre España y Uzbekistán por medio del intercambio de las buenas prácticas y experiencias en el campo universitario en este campo y en otros.

\section{ЎЗБЕКИСТОНДА ТУРИЗМ РИВОЖИ ВА ПАНДЕМИЯ}

\section{Холиқова Рахбар Эргашевна \\ тарих фанлари доктори, профессор \\ Тошкент давлат техника университети @tdtu.uz rahbarkholikova@mail.ru}

Annotation: The article touches on the fact that during the years of independence, the tourism sector has risen to a new qualitative level, as in other areas, and that many countries have introduced a visa-free regime.It is also indicated that the legislation was amended in order to liberalize liability for violations of the separation rules in our country.It will be noted about the work being done to reduce the negative impact of the corona virus pandemic.
Key words :

tourism, investment, cultural norms, international sphere, visafree regime, tourism, domestic tourism, legislation, passport system, administrative responsibility, consequences of a pandemic 
Ўзбекистонда туризмни ривожлантириш давлат сиёсати даражасига кўтарилди. Кундан кунга туризмнинг Ўзбекистон иқтисодиётига қўшадиган хиссасини ошириш асрлар оша кўз қорачиғидек асраб келинган тарихий ва маданий қадриятларимизни тарғиб қилиш бўйича аниқ чора-тадбирлар ишлаб чиқиш заруратга айланди.

Тарихан хам саёхат хам зиёрат учун қулай мамлакат бўлган Ўзбекистон деб аталган она заминимизда бутун дунёга маълум ва машхур бўлган буюк алломалар яшаб ижод қилганлар. Аждодларимиз қолдирган бой илмий-маданий мероси халқаро майдонда катта қизиқиш уйғотиши табиий. Мамлакатнинг туризми салохиятини биринчи навбатда инвестицияларни фаол жалб қилиш, сохага инновацион ғоя ва технологияларни жорий этиш, шунингдек мамлакатнинг бой табиий, маданий ва тарихий меросининг мавжуд ресусрлари ва имкониятларидан хар томонлама фойдаланиш хисобига ривожлантириш учун янада қулай шароитлар яратиш кераклиги таъкидлаб келинмоқда. Зеро бугунги кунда туризм барча мамлакатларда миллий иқтисодиётга салмоқли даромад келтирувчи сохалардан бири хисобланади.

Жамият хаётининг ижтимоий-иқтисодий ва маданий-маърифий сохаларида кенг қамровли ислохотлар амалга оширилиб бу жараёнда сифат ўзгаришлари ва туб муаммоларини хал этишда айниқса иқтисодиётни ривожлантиришда туризмнинг ўрни йилдан йилга ортиб бормоқда.

Ўзбекистон Республикасини 2017-2021 йилларда ривожлантиришнинг бешта устивор йўналиши бўйича Харакатлар стратегиясининг “Иқтисодиётни ривожлантириш ва либераллаштириш" деб номланган учинчи устивор йўналишида хам туризм индустриясини жадал ривожлантириш, иқтисодиётда унинг роли ва улушини ошириш, туристик хизматларни диверсификация қилиш ва сифатини яхшилаш, туризм инфратузилмасини кенгайтиришга хам катта эътибор қаратилган.

Туризмни ривожлантириш давлат қўмитаси ташкил этилди. Туризм тўғрисидаги қонун, шунингдек Президент ва хукуматнинг тармоқни ривожлантиришга қаратилган норматив-хуқуқий хужжати қабул қилинди. Туризм сохаси бошқа сохалар каби янги сифат босқичга кутарилди. 2016-2018 йилларда биргина туризм сохасида 30 дан зиёд норматив хужжатлар ва иккита стандарт ишлаб чиқилди. [1, 27]

2018 йил 10 февралдан бошлаб Исроил давлати, Индонезия Республикаси, Жанубий Корея Республикаси, Малайзия, Сингапур Республикаси, Туркия Республикаси ва Япония фуқаролари Ўзбекистон Республикаси худудида 30 кун визасиз яшаш имконияти берилди. Шунингдек, 101 мамлакат фуқароларига республикамиз аэропортларидан транзит саёхатчи сифатида харакатланишларида беш суткагача визасиз Ўзбекистонда бўлиш имконияти яратилди. 2018 йил 15 июлдан e-visa.uz сайти орқали хорижий сайёхларга электрон виза бериш тартиби жорий қилинди [2].

Шунингдек мехмонхона хизмати, транспорт ва сервис хизмати яхшиланди. Бугунги кунда Ўрта Осиё республикалари ва 100дан ортиқ давлатлар билан виза тизимининг енгиллаштирилиши зиёратчиларга ташриф буюриш имкони яратилди.

2019 йил 19 июль куни президентимиз томонидан “Туризм тўғрисида" қонун имзоланди. Ушбу қонун туризм сохасидаги муносабатларни тартибга солишга қаратилган бўлиб, туризмни ривожлантиришни хамма имкониятлари инобатга олинган

Виза режими соддалаштирилди. Қўшимча тарзда яна 47 мамлакат фуқаролари учун визасиз режим тадбиқ этилди. 2020 йил 1 январдан бошлаб эса республикага визасиз кирувчи мамлакатлар сони 86 тага етди. 
Мамлакатимизда туризм сохасининг ривожланишига берилаётган эътибор ва бу сохада олиб борилаётган ислохотларнинг туб мохияти мамлакатимизда иш ўринларини кўпайтириш, ахоли даромадларини ошириш, экспорт таркибини кенгайтириш ва инвестицион салохиятни ошириш орқали ахоли фаровонлигига эришишдир. Яратилаётган иш ўринларига муносиб кадрлар тайёрлаш тизимини такомиллаштириш мақсадида кўплаб олий таълим муассасаларида туризм сохасига кадрлар етказиш учун қўшимча мутахассисликлар очилишига алохида эътибор қаратилди. Хозирги кунда Тошкент давлат иқтисодиёт университети, Тошкент кимё технологиялари институти, Ўзбекистон халқаро Ислом академияси, Самарқанд иқтисодиёт ва сервис институти, Бухоро давлат университети, Урганч давлат университети, Фарғона давлат университети, Қарши давлат университети ва Наманган давлат университетида туризмнинг у ёки бу сохасига тааллуқли таълим йўналишлари ва мутахассисликлари бўйича бакалавр ва магистратура босқичларида мутахассислар тайёрланмоқда. Шунингдек, республикада 16 та касб-хунар коллежларида туризм сохаси учун ўрта махсус касбга эга мутахассислар тайёрланмоқда. Бу борада шуни алохида таъкидлаш керакки, 2018 йилда Президент қарори билан Самарқанд шахрида «Ипак йўли» туризм халқаро университети фаолияти ташкил этилди.[3, 197]

Мамлакатимизда туризмни ривожлантириш учун барча имкониятлар ишга солинмоқда. Айнан туризмни ривожлантиришда телекоммуникацияларнинг ўрни беқиёсдир. Сайёхлар кўп келадиган тарихий масканлар симсиз ва тезкор интернет тармоғи билан қамраб олиниши керак. Ўрганиш натижаларига кўра республикамизнинг энг катта тарихий шахарларидан бири бўлмиш, Самарқанд шахрида жами 107 та мехмонхона мавжуд бўлиб, шундан 11 таси оптик толали кабель орқали, қолганлари эса ADSL технологияси асосида интернет тармоғига уланган.

Шунингдек, Хоразм вилоятининг Хива шахридаги жами 37 та мехмонхонадан 32 таси симли телефон алоқаси хамда интернет тармоғига уланган. Бу холатни Бухоро шахрида хам кузатиш мумкин.

Президентимизнинг 2017 йил 19 майдаги 2017-2019 йилларда Бухоро шахри ва Бухоро вилояти сайёхлик салохиятини жадал ривожлантириш чора тадбирлари тўғрисидаги қарорида вилоятдаги сайёхлар тўпланадиган гавжум жойларада Wi-Fi худудларини яратиш билан боғлиқ вазифалар белгиланган эди.

Қарор асосида Бухоро шахридаги барча тарихий қадамжолар жумладан Пойи Калон, Лаби ховуз, Тоқи-Саррофон, Тоқи-Телпакфурушон, Тоқи Заргарон, Абу Али ибн Сино хиёбони, қадимий Арк майдони, Бухоро аэропорти хамда Бухоро автошох бекатлари, Ситори Мохи Хосса қасри, Темир йўл вокзали ва Бахоуддин Нақшбанд зиёратгохларига узоқ масофада ишловчи Wi-Fi узаткич қурилмалари ўрнатилиб, тайёр холга келтирилди. [4].

Йилдан йилга сайёхларнинг ташрифи кўпайиши, республикамизда бўлиш қоидаларига риоя этишини хам талаб қила бошлади. Эндиги кунда Ўзбекистон Республкасида бўлиш қоидаларини бузганлик учун жавобгарлиги масаласи кун тартибига чиқди. Қонунчиликда мамлакатда бўлиш қоидаларини бузганлик учун жиноий жавобгарлик белгиланган. Жумладан уч йилгача озодликдан махрум этиш жазоси назарда тутилган. Охирги уч йилда бу борада 76 та жиноят иши кўрилган.

Бундан ташқари қонунчиликда паспорт тизими ва Ўзбекистон Республикасида бўлиш қоидаларини бузганлиги учун маъмурий жавобгарлик хам белгиланган. 2016-2018 йилларда шу бўйича 18026 киши маъмурий жавобгарликга тортилган бўлса, улардан 11997 нафари хориж фуқаросидир. Кейинги йилларда хорижликларга мамлакатимизда бўлиш қоидаларини бузганлик учун жавобгарликни либераллаштириш борасида самарали чоралар қабул қилинди. 
Шу муносабат билан Ўзбекистон Республикаси Жиноят кодексининг 224моддасини чиқариб ташлаш бўйича қарор қабул қилинди. Унда чет эл фуқаролари ва фуқаролиги бўлмаган шахсларни ушбу қоидани бузганликлари учун жавобгарликка тортмаслик назарда тутилди.

Жарималар миқдорларини сезиларли равишда камайтириш эвазига маъмурий жазо чора-тадбирлари хам жиддий такомиллаштирилди. [5]

Бугунги кунда дунёдаги барча давлатлар қаторида Ўзбекистон хам пандимия оқибатида барча сохалардаги каби туризм сохасида хам инқирозни бошдан кечирмоқда. Дунё туризмида одамлар саёхат қилмаяптилар Хозирги кунга келиб тахминан 3 млрд. нафар одам изоляцияда ўтирибди. Дунё туризмида 75 млн.га яқин иш ўрни йўқотилган. Айни дамда ички туризмга кўпроқ эътибор қаратишга тўғри келади. Туризм сохаси вакиллари иқтисодий инқироз шароитида бу қийинчиликларни бартараф этиш бўйича таклифлар ишлаб чиқмоқдалар.

“Маълумки жорий йилнинг 16 мартидан Ўзбекистон ташқи ва ички саёхат учун ёпилган эди. Бунинг оқибатида 1,5 мингдан ортиқ туроператор, 1,2 мингта мехмонхона фаолиятини вақтинчалик тўхтатилган, бу эса гидлар, миллий хунармандчилик, зиёратгох ва сихатгохлар, умумий овқатланиш, транспорт ва бошқалар билан қўшиб хисоблаганда 250 мингдан ортиқ ахоли даромадига жиддий таъсир кўрсатаётганди. Пандемия даврида "Uzbekistan. Safe travel guaranteed" ("Ўзбекистон. Хавфсиз саёхат кафолатланган") бренди остида туристлар учун санитария-эпидемиологик хавфсизлик лойихасини татбиқ этилиши Ўзбекистон учун сайёхлик тизимини яна қайта тиклаб олиш билан бирга сайёхлар хавфсизлигини таъминлашда анча ахамиятлидир"[6].

Халқимиз пандимия шароитида бирлашиб бу офатни енгишга харакат қилаяпти. Тарихга назар солсак бундай офатлар жуда кўп бўлган, лекин бу офатлар инсонлар иродасини синдира олмаган. Инсонлар асрлар давомида бу каби офатларни ақл заковати билан бартараф этган.

Шундан келиб чиқиб, Президентимиз Шавкат Мирзиёев бошчилигида туризм сохаси барқарорлигини таъминлаш масаласига алохида эътибор қаратилмоқда.

Пандемиянинг оқибатларини юмшатиш мақсадида бу сохага хам қатор енгилликлар берилди. Жумладан, 1750 субъектга мол-мулк, ер ва ижтимоий солиқлардан 60 миллиард сўмга яқин имтиёз тақдим этилди, лекин бу имтиёз ва преференциялар вақтинчалик. Доимий барқарор ривожланиш учун пандемия шароитига мослашиб ишлашни ўрганиш керак.

Президентимизнинг 28 майдаги «Коронавирус пандемиясининг салбий таъсирини камайтириш учун туризм сохасини қўллаб-қувватлашга доир кечиктириб бўлмайдиган чора-тадбирлар тўғрисида»ги фармони айни муддао бўлди.

Ушбу фармон билан Ўзбекистон МДХ давлатлари орасида биринчилардан бўлиб 1 июндан ички туризмни қайта тиклаш бўйича ўзининг тартибтамойилларини маълум қилди. Бунда туризм сохаси субъектларининг белгиланган санитария-гигиена меъёрлари ва талабларига қатъий риоя этган холда 1 июндан «яшил» ва «сариқ» тоифадаги худудларда ички туризмни қайта йўлга қўйиши билан биргаликда ёндош ташкилотлар хам ўз фаолиятини бошлайди. Шунингдек, Ўзбекистон Республикасига киришга рухсат этиладиган мамлакатлар руйхатини белгилаб олган холда, ташқи туризмни босқичма-босқич қайта тиклаш режалаштирилган.

Фармонда тадбиркорлик субъектлари фаолиятини қўллаб-қувватлаш, уларга енгилликлар бериш кўзда тутилган. 2020 йил 1 июндан 31 декабрга қадар фойда солиғи ставкасини белгиланган ставкага нисбатан 50 фоизга камайтириш, 2020 ва 2021 йил якунлари бўйича зарарларни Ўзбекистон Республикаси Солиқ кодексида назарда тутилган миқдор билан чекламаган тарзда ўтказиш хуқуқи берилиши, 2021 
йил 1 январгача бўлган даврда туристик (мехмонхона) йиғимини хисоблаш ва тўлашни тўхтатиш кабилар шулар жумласидандир.[6]

Амалга оширилаётган ислохотлар, улкан бунёдкорлик ишлари Ўзбекистоннинг халқаро миқёсдаги обрў-эътиборини янада юксалишига хизмат қилади.

\title{
Адабиётлар :
}

1.Мансуров М.Ш. Фарғона водийсида туризмнинг ривожланиши жараёнлари ва холати (1980-2018 йиллар) 07.00.01-Ўзбекистон тарихи тарих фанлари бўйича фалсафа доктори (PhD) диссертацияси автореферати. -Т.,2019 йил.-Б.27.

2. Хива янада гўзал шахарга айланмоқда. Халқ сўзи. 2018 йил 31 октябрь. №225.

3.Ўзбекистон Республикаси Президенти Шавкат Мирзиёевнинг Олий Мажлисга Мурожаатномасини ўрганиш ва кенг жамоатчилик ўртасида тарғиб этишга бағишланган илмий-оммабоп қўлланма. -Тошкент.: Маънавият, 2019. 197-бет

4.Шухрат Мамажонов. Шарқона мехмондўстлик таомили .Халқ сўзи.2019. 9 октябрь.

5.Туризм ривожида телекоммуникация тармоқларининг ўрни. Халқ сўзи 2018 йил 4 апрель. №63.

6.Абдухакимов А. Ўзбекистон МДХ давлатлари орасида биринчилардан бўлиб ички туризмни тикламоқда. http//uza.uz/oz/seapch.

\section{DEVELOPMENT FOUNDATION OF LINGUISTIC AND SOCIO-CULTURAL SKILLS OF TOURISM SPHERE REPRESENTATIVES}

\section{Ashurov Shahobiddin Saidovich Associate Professor, Samarkand State Institute of Foreign Languages E-mail: ashaxobiddin@umail.uz}

\begin{abstract}
Annotation: $\quad$ The given article is forwarded to analysing of bases of development of linguistic, sociocultural attainments of representatives of tourism scope. In the article it has been analyzed the role of tourism in developing of country's social and cultural legacy and full information about basis of linguistic progress and studying of historical heritage during the practical occupation or preparatory courses of tourism sphere members. Furthermore, it is given some information about preparation of guides and interpreters in Uzbekistan.
\end{abstract}

Key words : tourism sphere, sociocultural, representative, linguistics, international, practical, professional preparation.

Nowadays, tourism is becoming the main source of income and progress of economic life in myriads of countries throughout the world. And representatives of tourism sphere play main role in provision prosperity and development of not only this sphere but also social, cultural and historical heritage of their country. Therefore, considerable attention should be placed on property and level of professional preparation of representatives of tourism sphere. It is undeniable fact that modern changing world of competence and practical skills requires necessity of constant training and staff's preparatory and its educational development.

Progress of tourism began in XX century in several European countries. Yet, today as it was mentioned, it has already spread all over the world, but educational system and practical skills of preparation of guides and interpreters are changing almost every year, because of traditional views, social norms, linguistic changes.

The main foundation of development of this specialty is qualitative higher education plaited with self-development and self-study, which became new educational paradigm of not «informational» but «notional» personally orientated study. Because future representatives of tourism sphere should understand substance of their professional preparation by experience themselves with not only scientific books or researches but also practising with people of another language. For practising guide or interpreter main reliance should not be only history 
or historical event, because their sphere must also be based on social and cultural heritages and skills, so as tourism is known as polyhedral scope. However, the professional preparation of representatives of this sphere should also be based on peculiarities of entrepreneurial activity. For this reason, nowadays there are great changes are held in order to improve the quality of cultural communication during the practical occupations of tourism sphere members. For example, development of material based on systematically theoretical knowledge, devoted to cross-cultural communication, to progress of cultural receptivity, ability of right interpretation of specific demonstration of communicative behaviour in cultural surroundings. Thus, nowadays, significant condition for foundation of practising students is given by using traditional and innovative technologies. And this experience evidenced that it is becoming useful to apply smart use of traditional lessons and also actual forms of united learning such as dialogues or analysing of multicultural or historical problems. Elaboration of system of guides' or interpreters' cultural preparation is based on finding out and firming of foundation of studying process by following skills: readiness for perception of culture and manners of foreign countries and nations, tolerance for different religions, ability to multicultural communication during the professional activity in tourism scope.

Representatives of tourism sphere are not only orderly person between different cultures and languages, they are converters who are responsible for transferring concepts and linguistic units, which may exist in one language but in another not. And therefore, linguistic preparation is very important for members of this scope. While translating proverbs and sayings guide or interpreter should be able to transfer them instantly but accurately and masterly into the other language, so as not all proverbs are may be translated literatim ${ }^{11}$ for example if we say: East or West home is best - Шарқми ёки Ғарб энг хши жой уйинг but analogue would be: Ўз уйинг ўлан тўшагинг. Another example: It is never late to learn Ўқишнинг хеч қачон кечи бўлмайди, but analogue would be: Бешикдан қабргача илм изла. If translate this proverbs word for word we can drastically change meaning of the word, and doing this guides may show not only that foundation of their practical skills are not good enough but also may render their disrespect to person of another language and culture. So good translation is one of the basic arms of interpreters.

Formation of linguistic competence of the tourism sector representatives contributes, on the one hand, to more effective professional training of future specialists, on the other hand, enriches theoretical and methodological foundations of foreign language education in tourism profile universities. And nowadays there is a task to teach students to elicit with the professionally significant information independently and develop sociocultural and linguistic skills for account of fixation materials.

The other main foundation of elaboration of development of skills in tourism scope, as it was mentioned above is theoretical studying which accentuate the professionally skilled character of specialists in this sphere. By way of progress of educational programs may be used «prognostic model» which is made by specialists in tourism sphere that is peculiar standard, elaborated on the basis of studying experience of headmost highly qualified specialists in this scope.

Interestingly, organized by the Decree of the Uzbekistan Republic President on November 8, 1994, Samarkand State Institute of Foreign Languages is one of the results of national independence of our country. At present, the institute has become one of the leading, internationally recognized centers for training highly qualified specialists in foreign philology for higher, secondary and secondary special education, as well as guides and interpreters for the tourism industry.

In light of this, training and education of intellectually and spiritually advanced youth meeting modern requirements has become a priority of our state policy. The need to solve this 
problem defines the main activities of our institute, which consists of 4 faculties, 20 departments, 10 language and cultural centers, Confucius Institute for Teaching Chinese Language and Culture at SamSIFL, a regional center for teaching foreign languages, a center for innovation and quality assurance in education, an information and resource center equipped with modern multimedia equipment. Training at the Institute is conducted in 14 Bachelors', 13 Masters' and 5 Doctoral specialties.

In the current academic year, 4975 students are studying at the Institute at the bachelor's level, 286 at the master's level and 21 at the doctoral level. The highly qualified faculty of the Institute provides educational, methodical, research, spiritual and educational work. The scientific potential of the Institute is high: 326 professors and teachers, including 18 doctors of science, professors, 57 candidates of science, associate professors, 251 teachers. There are also about 27 foreign specialists working at the Institute.

All the facts mentioned above certify that the foundation of development of linguistic and socio-cultural skills of tourism sphere representatives is being supervised on a high level and with great effort at our institute.

Tourism sphere appears as one of the important developing tendencies of social abd cultural connection between different nations and cultures. This polyhedral scope requires special professional preparation and eternal practicing. Therefore, the preparation of representatives of tourism sphere shouldn't be only based on development of linguistic, historical, social and cultural heritages, but also economical, religious and tolerance. Tourism based on this definition, the field of educational tourism covers all types of training and education that are carried out outside of a permanent place of residence. Thus, summing up the above, the following additions and clarifications in the conceptual apparatus tourism-specific educational tourism.

\section{References:}

1.Kudrina E.L., Iudina A.I., Mukhamedieva S.A. Sotsial'no-kul'turnye tekhnologii turistskoi deiatelnosti: proektnyi podkhod [Socio-cultural technology of tourist activity: design approach]. 2015, no 31, pp. 207-216. (In Russ.).

2. Malyshenko K.M. Modern problems of training the employees for river cruise tourism. Molodoi uchenyi [Young Scientist], 2011, no 9, pp. 221-224. (In Russ.).

3.Tel'manova A.S., Iudina A.I., Kulemzin A.M., Nasonov A.A., Rodionova D.D., Koveshnikova E.A., Tel'manova A.S. The first regional «Forum of Museum Workers on «Historical and Cultural Heritage of Kuzbass» 2012, no 20, pp. 258-262.

4. Alekseeva I.S Interpreters'professional training 2001. 287pp

5. Barhudarov L.S Language and translation. Questions of general and private translation's theory M., $1975.240 \mathrm{pp}$

6. Latishev L.T About some main competence of interpretation and their formation //Linguistics. Cross cultural communication. 1999. C.3-12.

7. Trusova N.M. The competitiveness of the tourist destinations. Internal tourism as a basis for sustainable development of the regions of Russia. Ed. E.L. Kudrina, D.D. Rodionova 2015, pp. 111-120.

8. https://eduscan.net/standart/100103

9. http://www.world-tourism.org/ruso/index.htm

10. http://ipk.admin.tstu.ru/bpi/bpiweb.exe/doc1263.doc? id=1263.

\section{SOUVENIRS ET APPRECIATIONS DE SAMARKAND}

\section{Hubert Boone \\ Musicien, membre du groupe Limbrant, Belgique}

Comme musicologue et violoniste non professionnel dans deux ensembles de musique traditionnelle belge, j'ai eu le privilège de pouvoir participer à une centaines de festivals, dont 
quelques dizaines à l'étranger. C'est ainsi que j'ai pu visiter une trentaines de pays ou régions en Europe, Amérique et Afrique. En Asie j'avais seulement visité l'Arabie-Saoudite, la Corée-duNord et plusieurs fois l'Arménie. Quand on participe un festival de musique dans un pays lointain, on a très souvent la chance de visiter quelques lieux ou les touristes ne passent pas, et on a la possibilité de s'entretenir avec la population locale. Après tout cela, les gens qu'on a rencontré, les souvenirs, les monuments et les beaux paysages font partie de la mémoire. Mais je n'ai jamais pu imaginer qu'un jour toutes ces souvenirs seraient en grande partie effacé par un seul voyage, plutôt inattendu, en Ouzbékistan.

En 2017 j'étais invité avec mon ensemble Limbrant pour participer au festival Sharq Taronalari à Samarkand. Un ami arménien m'avais déjà parlé avec beaucoup d'enthousiasme de ce lieu magique, appelé 'bijoux de la route de la soie'. Mais l'Asie centrale était une région que je n'avais jamais visité avant. Je connaissais Samarkand plutôt comme Marakanda, nom cité dans quelques textes historiques que j'avais lu sur Alexandre le Grand. Une fois arrivé, j'ai constaté bien vite que tous les grands mots et commentaires que j'avais déjà entendu, n'étaient pas exagéré. Samarkand, qui a été conçu en grande partie au 15ième siècle par le célèbre astronome Ulugh Beg, est un bijoux incomparable. Quand les guides du festival ont amené notre groupe à la place du Registan, la beauté nous a coupé le souffle : les différents monuments de ce lieu forment une unité parfaite, le style et les couleurs sont féeriques, et il reste des multiples détails d'une beauté époustouflante à découvrir et admirer. Le Registan a frappé le plus notre imagination, mais ce n'est pas le seul monument historique avec une beauté exceptionnelle. D'autres lieux qui nous ont fait rêver par leur charme et qui méritent une grande considération, sont par exemple Gur-e-Emir (15ième siècle.), le mausolée du grand conquérant Timour Lenk et la mosquée de Bibi-Khanum, construit pour la femme de Timour Lenk. Un autre endroit à ne pas manquer est le cimetière Shak-i-Zinda, un des plus importants exemples de l'Asie Centrale. Pour ceux qui s'intéressant à la science, il y a l'observatoire conçu par Ulugh Beg, qui était non seulement un conquérant, mais aussi astronome avec une réputation qui dépassait largement son pays. Son observatoire, un sextant construit en marbre, a une longueur de 63 mètres et permettait à déterminer la position du soleil, la lune et un bon nombre de planètes et étoiles.

En dehors de sa grande histoire et ses monuments exceptionnels, Samarkand, et l'Ouzbékistan en générale, a encore des multiples curiosités à offrir. On peut y faire des belles promenades et flâner dans les boulevards avec des grands arbres, réservant de l'ombre quand il fait trop chaud. Il y a des centaines de magasins avec autant de spécialités. Et à ne pas oublier, l'hospitalité et la gentillesse des Ouzbek. Même si on ne connait pas la langue, un contact avec l'habitant peut se faire sans problème. Pendant la période du festival en 2017, mon groupe a été assisté par deux guides parlant bien le Français, d'autres parlaient Anglais, Allemand etc. Le Français est en remonte dans cet partie de l'Asie, et il y a régulièrement des activités pour promouvoir les langues étrangères. C'est aussi avec ce but que le Samarkand State Institute of Foreign Languages organisera au mois de juin de cette année une conférence international pour le développement de son tourisme et la langue française.

Après la visite avec mon groupe en 2017, je suis déjà retourné trois fois à Samarkand accompagné de ma femme, et on y a fait des amis uniques. Nous y avons visité des petites manufactures où l'on réalise des tapis de grande inspiration artistique, un atelier où l'on fait du papier à la manière ancienne, un magasin d'instruments de musique traditionnelle. Pour passer les soirées, il y a des multiples restaurants et cafés. Samarkand compte plusieurs dizaines de bons hôtels à un prix payable et un service bien soigné. Samarkand est un lieu historique exceptionnelle à marquer dans ton carnet de voyages et à visiter au plus vite. 
Head of International Affairs of Bukhara

Branch of Tashkent institute of Irrigation

and agricultural mechanization engineers.

E-mail: sabirov.kodi@gmail.com

By now, tourism has become one of the leading sectors of the world economy. In this regard, Uzbekistan pays special attention to the modernization of the tourism industry, the development and improvement of the legal framework for the sustainable development of the industry, and the organization of services for foreign guests in accordance with international standards.

During the years of independence, Uzbekistan made a significant breakthrough in this area, along with the preservation and enhancement of the historical and cultural heritage of the people, the revival of national traditions and customs, the restoration and arrangement of attractions of the Republic.

In order to create a modern, highly efficient and competitive tourist complex, a strong legal framework has been formed in the Republic, based on the Law "on tourism", adopted on August 20, 1999. There are programs of targeted measures to improve the tourism infrastructure, including attracting investment, diversifying tourism products, activating educational and informational activities, and training and improving the skills of specialists in the sphere.

An important step in the formation of the national model of tourism was the creation Of the national company "Uzbektourism" in 1992 by decree of President Islam Karimov. Since then, the structure coordinates the activities of industry organizations, trains relevant personnel, promotes the inflow of internal and external investment in the creation of new and expanding existing material and technical base, encourages the development of all types of tourism, actively participates in foreign events, organizes major international forums.

The result of the measures taken in this direction is an increase in tourists arriving in Uzbekistan. Thus, every year Uzbekistan is visited by more than two million people from different parts of the world. The geography of foreign visitors is wide. Our country is particularly popular among citizens of Germany, France, Italy, the Republic of Korea, Japan, China, Malaysia, Russia, and India.

Since the first years of independence, Uzbekistan has been actively increasing its cooperation with international organizations and regularly takes initiatives to deepen cooperation in this promising area.

An important milestone in the history of domestic tourism was the Republic's entry into the UN world tourism organization (UNWTO) in 1993. Within the framework of cooperation with it, in 1994, 19 countries of the world adopted the Samarkand Declaration on tourism along the silk road. In 1999, the Khiva Declaration on tourism and the preservation of cultural heritage was adopted, supported by the UNWTO, UNESCO and the Council of Europe. In 2002 - the Bukhara Declaration on tourism along the silk road, which emphasizes the advantages of sustainable tourism and defines concrete steps to promote cultural and ecological tourism in this direction.

Moreover, in recognition of the Republic's special place in the world tourism industry, the UNWTO regional office for coordinating the development of tourism on the Silk road was opened in Samarkand in 2004. It should be noted that such an office 
exists only in two countries - Japan and Uzbekistan. Its main function is to identify directions in the development of not only regional but also international tourism.

Uzbekistan's capabilities are evidenced by the presence of more than seven thousand objects of material cultural heritage of different eras and civilizations, including the historical centers of Bukhara, Khiva, Samarkand and Shakhrisabz, which are included in the UNESCO world heritage list. World-famous historical monuments, modern cities, unique nature of Uzbekistan, unique national cuisine, as well as unsurpassed hospitality of our people attract travel lovers.

Thanks to the efforts of the Republic's leadership, the tourist infrastructure has been raised to a fairly high level in recent years. In particular, 1,176 tourist organizations, including 621 tour operators and 555 hotels, are successfully operating in the country. An extensive network of hotels with more than 25 thousand seats meets modern international standards.

Over the years of independence, thanks to truly large-scale construction and reconstruction of infrastructure facilities in Uzbekistan, 11 airports have received the status of international harbors. Modern comfortable aircraft of the national airline "Uzbekistan Airways", consisting of Airliners manufactured by Boeing and Airbus, perform regular flights to more than 40 cities in Europe, Asia, the Middle East and America. In 2016, the country's civil aviation fleet will be replenished with two modern "Dreamliners" - the Boeing Dreamliner.

Tourists visiting Uzbekistan have the opportunity to get to the sights of the Republic by rail. So, in addition to regular and high-speed trains, high-speed trains "Afrosiab" produced by the Spanish company Talgo run daily between Tashkent, Samarkand and Karshi, which significantly improved the quality of service to guests and reduced the travel time. In addition, in June 2016, the world witnessed another breakthrough in the development of the tourism and transport industry of Uzbekistan-the opening ceremony of the electrified railway line "Angren - PAP", which connected the picturesque Ferghana valley with the rest of the country.

In recent years, Uzbekistan has been actively introducing new types of travel, including eco-tourism. The presence of nature reserves, national parks, nurseries, nature reserves, natural monuments, biosphere reserves in the Republic makes ecotourism a very promising direction.

In addition, geotourism, medical tourism, mountaineering and rafting have developed in Uzbekistan. Recreation areas and comfortable infrastructure facilities are being built in the regions. For example, in the sports and recreation centers "Chimgan", "Beldersay" and "Charvak", located in the Tashkent region, the necessary conditions for skiing and other winter sports have been created. There are mountain trails of various types with a length of 300 to 3 thousand meters. Vacationers can climb the cable car using a special lift.

In Uzbekistan, the gastronomic direction of tourism is also gaining popularity, the development of which has made pilaf and other national dishes a recognizable brand of the country.

The current growth dynamics of the tourism industry confirms the need to modernize the training system for it, taking into account existing realities and prospects. The establishment of a number of educational institutions for training qualified specialists in this field was facilitated by the Decree of the President of the country "on training qualified personnel for tourism in Uzbekistan" dated 30 June 1999 and the Decree of the Cabinet of Ministers "on measures for further support and development of tourism in the Republic of Uzbekistan" dated 10 October 2012.

Today, there are five higher educational institutions in the country that produce specialists in this field: the Samarkand Institute of Economics and service, the Tashkent 
state University of Economics, the Bukhara and Urgench state universities, and the Singapore Institute for management development in Tashkent. Every year, more than 500 students who have graduated from universities in this specialty receive bachelor's degrees, and more than 40 - master's degrees. In addition, more than 3,500 employees graduate from 12 specialized professional colleges.

Major events regularly held in the Republic play a significant role in ensuring the accelerated development of the tourism sector of Uzbekistan, forming and maintaining the country's image on the world market. One of the most important annual events is the Tashkent international tourism fair "Tourism on the Silk road". Today it is the largest forum in Central Asia where industry professionals meet, negotiations are held in various formats, including business-to-business, the Hosted Buyers program is implemented for buyers of national tourist products, conferences are held on topical issues of the development of the tourism industry in Uzbekistan and the world as a whole.

Representatives of Uzbekistan also regularly participate in international fairs and exhibitions held abroad in order to present the tourism potential of the Republic. Participation in them allows you to stay up to date with the latest trends in the world tourism market, conclude business contracts, and develop cooperation with foreign partners.

Thus, the intensive development of the tourism industry in Uzbekistan, including a careful attitude to the historical and cultural heritage, the creation of infrastructure that fully meets international standards, and the strengthening of international relations have turned our region into one of the most visited countries in the world.

\section{ТУРИСТИК КЛАСТЕРЛАР: НАЗАРИЙ ЖАБХАЛАР ТАХЛИЛИ}

\section{Алимова Машхура \\ Иктисод фанлари доктори, доцент Илмий тадқиқотлар, инновациялар ва тижсоратлаштириш ишлари бўйчча проректор, “Ипак Йўли” Туризм халқаро Университети Аллаёров Р.A. \\ Самарқанд Иқтисодиёт ва Сервис Институти таянч докторанти}

Annotation: The article initially substantiates the proposal to use a cluster approach to increase the competitiveness of tourist regions of the Republic of Uzbekistan. Moreover, based on an analysis of theoretical approaches the essence of the tourist cluster, the principles of its formation and development have been developed
Key words : tourist cluster, competitiveness, transaction costs, synergistic effect, cooperation, cooperation, concentration, innovation

Ўзбекистонда туристик худуднинг рақобатбардошлигини оширишга қаратилган янгича назарий ёндашувларни ишлаб чиқишга бўлган эхтиёж дунё тажрибасини ўрганиб чиқишни талаб этмоқда. Бу борада тўпланган назарий ва амалий тажрибаларни тахлил қиладиган бўлсак, инновацион ёндашувларга асосланган худудий кластерлар худуд рақобатбардошлигини оширишнинг энг самарали шаклларидан бири хисобланади.

«Кластер» тушунчаси инглиз тилидан келиб чиққан бўлиб, “попук”, “бир шингил”, “тўп”, “тўплам” каби маъноларини англатади. “Кластер” тушунчасини биринчи бўлиб фанга Гарвард бизнес мактаби профессори Майкл Портер киритган. 
Портер эътироф этишича, «кластер - бу бир-бири билан рақобатлашувчи, лекин шу билан бирга бутун кластернинг рақобатбардошлигини таъминлаш мақсадида ўзаро хамкорликда фаолият юритувчи, географик жихатдан концентрациялашган ташкилотларнинг ўзаро боғланган гурухлари, улар фаолиятига ихтисослашган хизмат кўрсатиш ташкилотлари, жихозлар етказиб берувчи ташкилотлар, уларга хамрох тармоқ ташкилотлари, шунингдек, уларнинг фаолияти билан боғлиқ турли соха ташкилотлари (илмий-тадқиқот институтлари,ОЎЮлари, стандартлаштириш бўйича агентликлар, савдо уюшмалари ва х.к.) ва бошқа бир қатор ташкилотлар гурухидир». (1) Портер ўз тадқиқотлари натижасида, халқаро миқёсда битта тармоқ доирасидаги ўзаро рақобатбардош ташкилотларнинг географик жойлашуви жихатидан тизимсиз равишда турли хил давлатларда сочилиб кетмасдан, балки айнан битта давлат, хаттоки битта худуд доирасида концентрациялашув хусусиятига эга эканлигини аниқлаган.

Ушбу холатнинг юзага келиши тасодифий эмас. Халқаро бозорда бир ёки бир гурух ташкилотлар рақобатбардошликка эришгач, худудий жихатдан ўзларига географик жихатдан яқин жойлашган хом-ашё етказиб берувчи ташкилотлар, рақобатчи ташкилотлар ва бир қатор бошқа хамкор ташкилотларнинг иқтисодий фаолияти ва холатига таъсир эта бошлайдилар. Шу билан биргаликда, уларнинг ютуқлари мазкур ташкилотлар рақобатбардошлигининг ошишига ижобий таъсир этади. Бунинг оқибатида “кластер”, яъни бир-бири билан узвий боғланган, хамда рақобатбардошлигини ўсишига ўзаро кўмаклашувчи ташкилотлар уюшмаси вужудга келади. М.Портер, худуд рақобатбардошлигини оширишнинг асосий харакатлантирувчи кучи бўлмиш кластерлар: “ташкилотлар, давлат тузилмалари ва бошқа хамкорлик ташкилотлари (мактаб, университетлар) ўртасида ўзаро мулоқот ўтиши мумкин (хаттоки зарур) бўлган майдонни ташкил этади" (1), - деб таъкидлайди.

Россиялик олим Н.А.Корчагинанинг фикрига кўра: “Кластерлар рақобатни рағбатлантируви очиқ тизимлардир. Уларнинг мақсади, белгиланган нархларни ушлаб туриш (фиксация) ёки рақобатни чеклаш эмас. Зарурий ахборотнинг ўзаро алмашинуви, хамкорликда илмий тадқиқотлар ёки экспортга қаратилган харакатлар рақобатни чекламайди, аксинча ташкилотлар рақобатбардошлигининг ошишига олиб келади. Горизонтал ва вертикал алоқалар орқали бир-бири билан узвий боғланган ташкилотларнинг талаб ва истакларини ўзаро мувофиқлаштириш хамда ахборотлар харакатини таъминловчи шароитлар кластерни самарали фаолият кўрсатишининг асосий механизмлари бўлиб хизмат қилади» (2).

Кластерларга хос бўлган хусусиятлар қуйидагилар:

- кластердаги ташкилотлар географик худудда бир-бирига яқин жойлашганлиги;

- самарали ахборот тизимининг шакллантирилганлиги сабабли кластер элементлари ўртасида ахборот алмашув тезлигининг юқорилиги;

- бизнесда шериклар ўртасида ўзаро ишончнинг мавжудлиги;

- ташкилотлар ўртасида бир вақтнинг ўзида шерикчилик ва рақобатнинг мавжудлиги хамда ушбу муносабатларнинг ўзаро боғлиқлиги;

- кластерни ривожлантиришга йўналтирилган инвестицияларнинг бир вақтнинг ўзида кластерда қатнашувчи бир нечта ташкилотларга самара келтириши;

- инновацион лойихаларни ишлаб чиқиш йўлида бизнес, илм-фан ва давлатнинг ўзаро хамкорлиги;

- кластерга кирган ташкилотларнинг географик жихатдан яқин жойлашганлиги сабабли худуддаги ресурслар ва хомашёлардан баравар фойдаланиши туфайли трансакцион харажатларнинг камайиши хамда худудий кластерларда синергетик самаранинг вужудга келиши натижасида худуд хамда бутун мамлакат иқтисодиётининг сезиларли ривожланишига сабаб бўлиши. 
Агар дунё амалиётига назар соладиган бўлсак, сўнгги икки ўн йиллик давомида кластерларнинг шаклланиши жараёни жадал амалга ошган. Экспертларнинг фикрича, дунё миқёсида етакчи давлатлар иқтисодиётининг 50 фоизини кластерлар қамраб олган. Мисол учун, бугунги кунда АҚШ иқтисодиётида фаолият юритаётган ташкилотларнинг ярмидан ортиғи кластерлар томонидан қамраб олинган бўлиб, мамлакат ЯИМининг деярли 60 фоизи уларнинг хиссасига тўғри келади. Европа Иттифоқи давлатларида эса 2000га яқин кластерлар мавжуд бўлиб, уларда дунё миқёсида мехнатга лаёқатли ахолининнг 38 фоизи фаолият юритмоқда. Масалан, Финляндияда енгил саноат, ахборот технологиялари, ўрмон хўжалигини қамраб олган 9та кластер, Германияда фармацевтика, косметика, автомобилсозлик, биотехнологиялар, электроника сохаларини қамраб олган 32та кластер, Буюк Британияда биотехнологиялар, биоресурслар ва бошқа бир қатор сохаларни қамраб олган 168та кластер, Данияда тиббиёт, фармацевтика сохаларини қамраб олган 34та, Италияда агросаноат, озиқ-овқат саноатини қамраб олган 206 кластерлар, Францияда 96та, Голландияда 20та кластерлар мамлакат иқтисодиётида фаолият юритмоқда. Жахон хамжамиятига тобора кучлироқ киришиб бораётган мамлакатимизда хам кластерларни ташкил этиш долзарблашиб бормоқда. Хусусан, юқори туристик салохият жамланган худудларда туристик кластерни шакллантириш ва ривожлантириш мамлакат иқтисодиёти учун мухим ахамият касб этади.

Демак, худуд иқтисодиётининг ривожланишида кластерли ёндашув унинг хусусий сектори, йирик ташкилотлари, давлатнинг маъмурий тузилмалари ва таълим ташкилотлари ўртасида узвий боғлиқлик ва алоқадорликни таъминловчи асосий ташкилий-иқтисодий механизм бўлиб хизмат қилиши мумкин. Бунда хукуматнинг асосий вазифаси, худудлар ижтимоий-иқтисодий имкониятларидан келиб чиққан холда, керакли кластерларни аниқлаш, уларни шакллантириш ва ривожлантириш бўйича стратегик режани ишлаб чиқиш, кластерли ёндашув асосида ривожланишнинг институционал асосларини шакллантириш хисобланади.

Кўпчилик олимлар ўз тадқиқотларида кластерли ёндашувлардан келиб чиққан холда, “туристик кластер" тушунчасинининг мохиятини очиб беришга қаратилган таърифларни келтиришган. Ушбу таърифларда “туристик кластер” тушунчаси уч хил ёндашув, яъни тизимли, тузилмавий ва жараёнли ёндашувлар асосида тахлил қилинган.

Илмий асарларда “туристик кластер” тушунчасига келтирилган таърифларнинг илмий-назарий тахлиллари шундан далолат берадики, П.М.Маевский, О.Н.Лучко, Е.В.Кулагина, М.А.Грицай, Г.И.Мокеев, Е.Г.Кропинова, М.Монфорт, С.К.Куна каби олимларнинг илмий қарашлари ушбу тушунчанинг мазмун ва мохиятини очиб беришда тизимли ёндашувга асосланган бўлиб, “туристик кластерлар” уларнинг объектлари (туристик аттракторлар, туристик инфратузилма) ва субъектларининг (туристик кластер қатнашчилари) мажмуаси сифатида талқин этилган.

Тузилмавий ёндашувлар асосида ишлаб чиқилган таърифларда “туристик кластерлар" субъектлар тузилмаси сифатида изохланган. Хусусан, И.Г.Шепелев, Ю.А.Маркова, О.Д.Коль, А.Д.Осминкина, А.И.Тарасенок каби мутахассислар томонидан берилган таърифларда туристик кластернинг субъектлари сифатида фақатгина тадбиркорлик фаолияти субъектлари кўриб чиқилган. Аммо Ю.Ю.Морозова, В.И.Кружалин, 3.И.Созиева, Ф.Капоне томонидан берилган таърифлар бирмунча комплекс тавсифга эга бўлиб, улар туристик кластер субъектлари доирасига тадбиркорлик фаолияти субъектлари билан бир қаторда, давлат хукумати органлари ва ижтимоий ташкилотларни хам киритишган.

Жараёнли ёндашувга асосланиб берилган таърифларда туристик кластер биргаликдаги харакатлар, кооперация жараёни сифатида талқин этилган. Бундай 
нуқтаи назарни А.И.Митрофанова, А.Н.Хваджа, Б.И.Рассадин каби олимлар ўз илмий асарларида илгари суришган.

Туристик кластерларга берилган таърифларга асосланиб, уларнинг шаклланиши ва амал қилишининг қуйидаги тамойилларини алохида ажратиб кўрсатиш мумкин: 1) хўжалик юритиш бирликларининг худудий концентрацияси; 2) “қўшилган қиймат яратиш занжири”да қатнашиш асосида кластер аъзоларининг чуқур технологик коооперацияси; 3) кооперация ва рақобатнинг уйғунлиги; 4) инновацион жараёнларнинг хослиги; 5) давлат ва хусусий бизнеснинг хамкорлиги. Ушбу тамойилларнинг амал қилишини қуйидагича изохлашимиз мумкин:

Биринчидан, туристик кластер шаклланишининг асосий шарти хўжалик юритиш субъектларининг географик жихатдан яқинлиги хисобланиб, бу ўз навбатида, транспорт ва коммуникация харажатларининг камайиши, тезкор иқтисодий таъсир орқали тежаш ва ижтимоий капитал билан ўзаро айрибошлаш имкониятларининг вужудга келишини таъминлайди. Туристик кластерларнинг географик кўлами локал, худудий ва худудлараро даражаларгача чўзилган бўлади.

Иккинчидан, туристик кластер мураккаб ички тузилмага эга. Унинг доирасида туристик махсулотларни ишлаб чиқувчи ва реализация қилувчи туристик ташкилотлар (туроператорлар ва турагентлар), уларнинг контрагентлари, хамкор ташкилотлар, шунингдек, таълим муассасалари, илмий-тадқиқот ташкилотлари фаолият юритади. Туристик кластер аъзолари "қўшимча қийматнинг яратилиши занжирлари"да ва “қийматнинг тўпланиши" тизимида қатнашиш асосида ўзаро мураккаб технологик кооперацияга киришади.

Учинчидан, кластернинг мохияти, унга аъзо ташкилотлар ўртасида ўзаро хамкорлик ва рақобат алоқалари хослиги билан намоён бўлади. Бир хил ёки ўхшаш махсулотлар ишлаб чиқарувчи хамда қўшимча қиймат яратиш занжирининг битта бўғинида қатнашувчи ташкилотлар тўғридан-тўғри рақобатчилар хисобланиб, аммо туристик кластер доирасида улар бир вақтнинг ўзида турли йўналишдаги стратегик альянсларга бирлашадилар. Шундай шаклдаги рақобатчи-қўшничилик ишлаб чиқариш унумдорлигини оширишга йўналтирилган барча технологик ва махсулотга доир янгиликларни тадбиқ этишнинг асосий харакатлантирувчи кучи сифатида хизмат қилади.

Тўртинчидан, туристик кластерларга юқори даражадаги ички рақобат мухити хосдир. Ушбу мухит чекланган географик худудда катта миқдордаги туристик ташкилотлар, уларга хамрох тармоқлар ташкилотларининг хамда иқтисодий ресурслар хамда туризм бозорининг самарали фаолият юритишини таъминловчи катта хажмдаги зарурий ахборотларнинг тўпланиши натижасида яратилаётган туристик махсулот турларининг кўпайиши ва сифатининг ошишига эришилади. Бунда кластер доирасида ўзига хос инновацион мухит шаклланади, бу холат мухитда фаолият юритаётган ташкилотларнинг халқаро миқёсда рақобатбардошлигини таъминлаш учун хизмат қилади.

Бешинчидан, туристик кластерлар давлат ва хусусий бизнеснинг хамкорлиги негизида шаклланади ва ривожланади. Давлат туристик кластерни шакллантириш ва ривожлантириш жараёнида мухим ахамиятга эга бўлган мувофиқлаштирувчи, тартибга солувчи ва рағбатлантирувчи вазифаларни бажаради. Айниқса, кластер шаклланишининг бошланғич босқичларида унинг ўрни алохида ахамиятга эга. Шунингдек, давлат ўзига ажратилган вазифани хусусий бизнес билан хамкорлиги орқали амалга оширади.

Шундай қилиб, бизнинг фикримизча, туристик кластер - бу худуднинг туристик салохиятидан самарали фойдаланиш асосида худудий туризм тизимининг рақобатбардошлигини таъминлаш мақсадида туристик махсулотни шакллантириш ва реализация қилишнинг технологик жараёнида бевосита ёки билвосита 
қатнашувчи ва давлат бошқарув органлари, таълим муассасалари, илмий тадқиқот институтлари билан ўзаро узвий алоқада бўлган, географик жихатдан яқин жойлашган ташкилотлар хамда уларнинг ўзаро хамкорликдаги ижтимоий-иқтисодий муносабатлари мажмуидан иборат очиқ иқтисодий тизимдир.

Туристик кластерни шакллантириш асосида кластер доирасидаги турли тармоқ корхоналари ўртасида туристик махсулотни яратиш ва реализация қилишнинг барча босқичларида зарурий ахборотлар эркин харакатининг таъминланганлиги ётади. Ўзаро рақобат курашида устунликка эришиш мақсадида, ушбу корхоналарнинг мавжуд ахборотлардан ўз мақсадларида якка тарзда фойдаланиш истаги тадбиркорлик фаолияти субъектлари ўртасида ахборотларнинг эркин харакатига тўсқинлик қилиши мумкин. Аммо, бу ташкилотларнинг ўзаро эркин ахборот алмашинуви орқали, ташқи рақобатчиларга нисбатан устунликка эришиш имкониятини келтириб чиқарувчи шароитларнинг вужудга келтирилиши, уларнинг ички бозордаги "рақобатбатга дош бермаслик" каби хавотирларидан устун турувчи манфаатдорликни келтириб чиқаради. Бизнинг фикримизча, туристик кластер доирасида унинг барча иштирокчилари фаолияти хақида, худуднинг мавжуд туристик объектлари тўғрисидаги ахборотлар мажмуини қамраб олган маълумотлар базасининг яратилиши хамда уларни узатиш механизмининг ишлаб чиқилиши туристик кластер таркибидаги турли ташкилотлар ўртасида узвий алоқаларни таъминловчи асосий восита бўлиб хизмат қилади.

\section{Адабиётлар:}

1. Портер М. Конкуренция. Пер. с англ. - М.: Издательский дом «Вильямс», 2005, с. 256.

2. Корчагина Н. А. Кластерная политика - технология повышения эффективности управления компаниями:моногр. - Астрахань: Изд. дом «Астраханский университет», 2009. с.68

\section{ФРАНЦУЗ ТУРИЗМИ ДИСКУРСИДА VOYАGЕ ОЛАМИНИНГ ЛИНГВОМАДАНИЙ МАНЗАРАСИ}

\section{Исмочлов Салохиддин Исмоилович Филология фанлари номзоди, доцент Самарқанд давлат чет тиллар институти E-mail: ismoilov@samdchti.uz}

Annotation: This report examines the linguocultural picture of the world of the conceptvoyage in the French tourism discourse. The semantic and national cultural specifics of linguistic units that serve to express the conceptual components of the Voyage concept are described on the basis of lexicographic sources.
Key words : travel, concept, conceptual content, lexicographic source, synonymous lexical units.

Бугун туризм, пандемиянинг мавжуд сифат ва миқдор кўрсаткичларига қарамасдан, бутун дунёдаги энг жозибадор ва сердаромад сохалардан бирига айланиб улгурган. Шу туфайли хам Жахон сайёхлик ташкилоти томонидан 1997 йилдан буён хар йили 27 сентябрь санаси "Халқаро туризм куни” сифатида нишонланади. Барчамизга маълумки, қадимда Марказий Осиё худудидан Буюк Ипак Йўлининг ўтганлиги юртимиз худудида яшаган ахолини бошқа мамлакатлар билан маданий, савдо-сотиқ алоқаларини ўрнатишга ундаш билан бирга, ўзга юрт ахолиси онгида хам халқимизнинг яшаш тарзи, урф-одатлари, тарихи, маданияти, иқтисоди тўғрисида қизиқиш тасаввурларининг пайдо бўлишига замин яратиб келган.Бундай мавхум тасаввурларнинг кенг миқёсда воқеликка айланишига таъсир этувчи омиллардан бири, назаримизда, мустақилликнинг дастлабки йилларидан бошлабтуризмга, давлат сиёсати даражасида, 
эътиборнинг кучайишидир. Ўзбекистон Республикасипрезидентининг 1992 йил 27 июлдаги фармонига мувофиқ “Ўзбектуризм" миллий компанияси ташкил этилди. Орадан бир йил ўтиб, мамлакатимиз жахон сайёхлик ташкилотига аъзо бўлди. 1999 йилга келиб эса “Туризм тўғрисида”ги қонун қабул қилинди.Туризм сохасига бундай стратегик ёндашувлар юртимизда хам сўнгги йилларда туризмнинг шиддат билан ривожланиб бораётган сохалардан бирига айланишига таъмал тошини кўйди. 20192025 йилларда Ўзбекистон Республикасида туризм сохасини ривожлантириш Концепциясимувофиқ, туризмконцептининг барча таркибий қисмлари бўйича амалга оширилиши лозим бўлган истиқболли тадбирлар ишлаб чиқилди. Шундай тадбирлардан бири туризм тармоғи учун кадрлар тайёрлаш, қайта тайёрлаш ва малакасини ошириш тизимини такомиллаштириш тадбиридир.

Туризм жамият хаётида маданий-тарихий ходиса сифатида иқтисодий, ижтимоий психологик, идеологик, маънавий ва коммуникатив томонлардан тавсифланади. Халқаро ва миллий маданий омилларни бирлаштириш ушбу ходисанинг маданий хусусиятларидан биридир. Туризмнинг кенг миқёслилиги ва оммавийлигига асосланган холда, уни маданиятлараро мулоқотнинг мухим омилларидан бири, ижтимоий-маданий макондаги харакат сифатида кўриб чиқиш мумкин. Туризм табиатан коммуникативдир. Сайёхат пайтида сайёх дуч келадиган асосий муаммолардан бири - бу хорижий маданиятни англашдир. Сайёхнинг муваффақиятли мослашиши ташқи ва ички омилларга боғлиқ бўлиб, уларнинг энг асосийси маданият ва таълимнинг умумий даражасидир.

Мазкур маърузада voyageконцептининг тушунчавий, бахоловчи ва қадриятли таркибий қисмларидан фақат биринчисига эътибор қаратилади. Бунда voyage тушунчасининг луғат мақолалари ва таърифларида ифодаланган ва француз лисоний онгида шаклланган турли семантик қирраларини тақдим этишга хизмат қиладиган лексик бирликлар кўриб чиқилади. Тахлил, француз тилининг Dictionnaire Hachette encyclopédique illustré [1], Le Nouveau Petit Robert [2],Littré [4], Dictionnaire des synonymes par Henri Bénac [6], Dictionnaire de synonymes et contraires par H. B. du Chazaud [5], Dictionnaire étymologique de français par Jacqueline Picoche[3] луғатлари маълумотларига асосланган холда, voyage тушунчасини ифодалашга хизмат қиладиган лисоний бирликларнинг мажмуини тизимлаштиришни назарда тутади. Зеро бу лисоний бирликлар асосида турувчи фон билимларини идрок этиш ва эгаллаш саёқатнинг муаффақиятли амалга оширилишида мухим рол уй̆найдиган гид-таржимон учун хаводек зарур.Бундай лексик бирликлар қаторига қуйидагиларни киритиш мумкин:pèlerinage (зиёратларга пиёда бормоқ, саёхат қилмоқ), exploration (илмий экспедиция), expédition (экспедиция, саёхат),périple (дунё бўйлаб саёхат, туристик саёхат), pérégrination (узоқ ерларга сафар қилиш, узоқ сафар), tournée (турне, гастрол сафари), campagne (саёхат, харбий флотнинг узлуксиз харакат даври),déplacement (кўчиб юриш, жойни ўзгартириш), croisière (денгиз саёхати), incursion (рейд, юриш), odyssée (одиссея), voie (йўл), trajet (саёхат, парвоз). Санаб ўтилган хар бир тушунчанинг асосида қандйдир бир аниқ нарса туради. Шу нуқтаи назардан ушбу лексик бирликларни кўриб чиқамиз.

Pélerinage биринчи бўлиб XI асрнинг бошларида "voyage entrepris dans un but religieux, vers un lieu saint" (диний мақсадда муқаддас жойга саёхат) маъносида қўлланган. XII арга келиб pélerinage сўзининг маъноси croisade (салиб юришлари) сўзининг маъносига мос келган. Бир вақтнинг ўзида "voyage" (саёхат) маъноси пайдо бўлган. XIII acp бошида pélerinage сўзи "la vie humaine" (инсон хаёти) етафорик талқинини олган. XIX асрда унинг хозирги: "voyage fait en un lieu pour rendre hommage, se recueillir" (ўз рухий мушохадасига берилиши асосида амалга ошириладиган саёхат) маъноси пайдо бўлган.

Expédition сўзи лотин тилиданўзлаштирилган: expeditio -"préparatifs de guerre, campagne" (урушга, харбий сафарга тайёргарлик). XIII асрда "action d'exécuter ce qu'on a à 
faire" (зарур нарсани бажариш бўйича харакат) маъноси ва XVI асрда "opération militaire exécutée au loin" (узоқ масофали харбий операция) маънолари қайд қилинган. XVII асрнинг охирига келибсўзлашув тилида expédition сўзи "voyage, équipée" сифатида икки хил талқин қилинган: 1) ўйламай қилинган, дадил ташаббус; хийла-найранглар; 2) (эркин) сайр қилиш; қисқа вақт бирор жойга чиқиб кетиш.

Croisièreлексемаси croix (хоч) сўзининг хосиласи. XIII асрдасroisade (салиб юриши) сўзи пайдо бўлган.Croisièreлексемаси croiser феълининг дериватидир. Бу феъл «disposer en croix» (крест шаклида жойлаштирмоқ), «couper la route à un navire» (кема йўлини тўсиб қўймоқ), «aller et venir dans les mêmes parages» (битта худудда юрмоқ) маъноларига эга бўлиши мумкин. Croisière лексемаси «parage où les vaisseaux vont croiser» (кемалар қатнайдиган йўл) ёки «action de croiser» (навигация харакатлари)денгиз атамаси сифатида XVII асрда пайдо бўлган. Фақат XX асрда «voyage d'études ou touristique» (таълим сафариёки туристик саёхат) маъноси қайд қилинган.

Déplacementлексемаси déplacer феълининг деривати бўлиб, XVII асрда қайд қилинган: desplacement "action de déplacer quelque chose" (бирор нарсанинг жойини алмаштириш харакати).

Campagne лексемаси лотин тилидагисаmpus - «terrainplat» (текис ер, майдон) сўзидан келиб чиққан. XII асрда қайд қилинган ушбу лексема «éspace découvert» (ким томондандир кашф этилган ер) маъносига эга бўлган. Кейинчалик XVI ва XVII асрларда armée en campagne (сафардаги армия) ва campagne militaire (харбий кампания) маъноларида қўлланган.

Odyssée лексемаси "récit de voyages et d'aventures" (саёхат ва саргузаштлар хақида хикоя) маъносида қўлланган. XIX асрда odyssée лексемасининг маъноси «voyage semé d'aventures» (саргузаштларга тўла саёхат) маъносига ўзгарган. Уша асрнинг охирида odyssée intérieure (ички саёхат, чуқур ўзини кузатиш) ибораси пайдо бўлган. Шундай қилиб, Улусснинг саёхатларига бағишланган Гомернинг “Одиссея" достони номидан образли фойдаланиш юқорида таъкидланган тўғри ва метафорик маъноларнинг пайдо бўлишига олиб келган.

Périple лексемаси лотин тилдаги periplus сўзидан ўзлаштирилган бўлиб, «naviguer autour» (бирор нарса атрофида кемада сузиб ўтиш), «денгизда сузмоқ, юрмоқ» маъноларига эга бўлган. XVIII аср охирида "voyage, randonnée par voie de terre, circulaire ou non" (халқа йўли бўйича ихтиёрий саёхат, ер устида уюштирилган саёхат) маъносида қўлланган, унинг хозирги маъноси хар доим хам айланма саёхатни англатмайди, кўпроқ нейтрал «қисқа муддатли саёхат; туристик саёхат» маъносида қўлланади.

Кўриб чиқилган лексик бирликлар кенг қамровли voyageконцептининг муайян тушунчавий таркибий қисмларини ифодалашга хизмат қилмоқда. Саёхат даврида жойни ўзгартириш семаси барча лексемалар учун умумий асосий сема бўлиб, voyageкомпонентли турли сўз бирикмалари воситасида ифодаланиши хам мумкин: entreprendre, faire un voyage (саёхат қилмоқ); faire le voyage de Samarkand, de Boukhara (Самарқандга, Бухорага саёхат); il faudra faire plusieurs voyages (бир нечта саёхатлар қилиш керак); être en voyage (саёхатда бўлмоқ); partir en voyage (саёхатга жўнаб кетмоқ) ва х.з.

Маърузада voyageтушунчаси билан боғлиқ муайян атрибутлар (vêtements, couvertures, sacs de voyage; notes, carnets, souvenirs de voyage; livres, recits de voyage ва б.), саёхатни амалга оширадиган транспорт воситалари (voyage à pied, en voiture, en avion), макон омили (voyage à travers l'Europe, voyage par mer, voyage circulaire), замон омили (balade, chevauchée, circuit, croisière, déplacement, excursion, itinéraire, méharée, microturisme, navigation, pérégrination, périple, promenade, raid, rallye ва б.), саёхат мақсади (voayged'affaires, voyage d'agrement, voyage de noces, voyage touristique, voyage d'études, d'exploration, d'information) лингвомаданий ва лингвопрагматик аспектларда талқин этилади. 


\section{Адабиётлар:}

1. Dictionnaire Hachette encyclopediqueillustré [Текст]. - Paris. : Hachette livre, 2001. - 2066 c.

2. Le Nouveau Petit Robert [Текст] / Rey-Debove J., Rey A./Dictionnaire Le Robert. -Paris, 2006. -2949 c.

3. Dictionnaireétymologique de français par Jacqueline Picoche. - Paris : Les usuels du Robert, 1991. $830 \mathrm{p}$.

4. DictionnaireLittré [Электронныйресурс]. -Режимдоступа : http: // francois. gannaz. free. fr / Littre / accueil. php.

5. Dictionnaire de synonymesetcontraires par H. B. du Chazaud. - Paris : Le Robert, 1999. - 768 p.

6. Dictionnaire des synonymes par Henri Bénac. -Paris : Hachette, 1981 - 1026 p.

\section{МАХСУС ЛОЙИХАЛАР - ТАЪЛИМ ВА ТУРИЗМ УЗВИЙЛИГИНИ ТАЪМИНЛАШ ВОСИТАСИ СИФАТИДА}

\section{Сувонова Нигорабону Низомиддиновна \\ Филология фанлари номзоди, доцент \\ Самарқанд давлат чет тиллар институти \\ E-mail: suvonova@samdchti.uz}

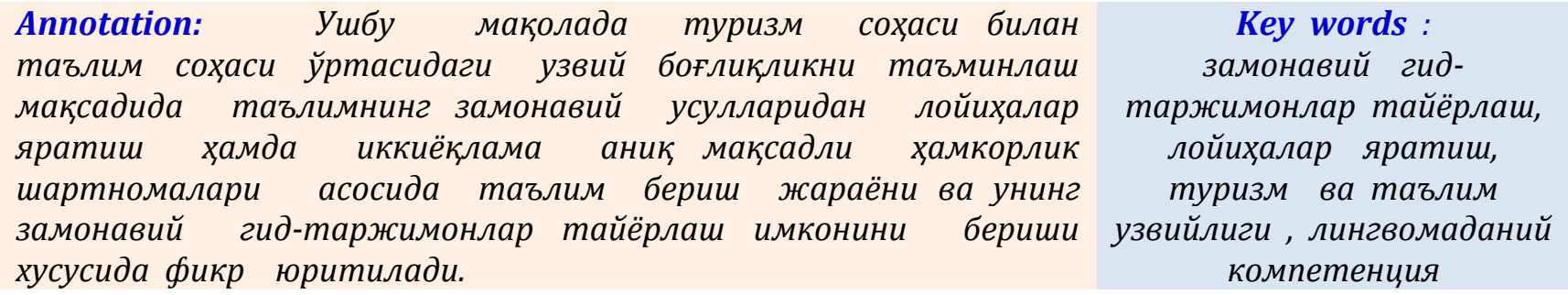

Респубикамизда туризмни ривожлантириш жараёнида замонавий гид таржимонларни тайёрлаш масалалари хорижий тил мутахассисларини тайёрлаб чиқарувчи олий таълим муассасалари олдига масъулиятли бир вазифани юклайди. Бинобарин, Ўзбекистон Республикаси Президентининг 2016 йил 2 декабрдаги ПФ-4861-сонли «Ўзбекистон Республикасининг туризм сохасини жадал ривожлантиришни таъминлаш чоратадбирлари тўғрисида» номли Фармонига мувофиқ, туризм сохаси ва туризм инфратузилмасини ривожлантиришни янада қўллаб-қувватлаш, миллий туризм махсулотлари ва брендларини халқаро туризм бозорларида фаол тарғибот қилиш масалаларига алоқида эътибор қаратилган.

Хусусан, Республикамизда туризм сохасини қўллаб-қувватлаш мақсадида мехмонхоналар, туризм базалари ва мажмуалари, дам олиш уйлари ва зоналари, пансионатлар, кемпинглар, мотеллар, миллий мехмон уйлари, ўтовли оромгохлар, санаторийлар ва бошқа мехмонхоналарда хорижий тилларни мукаммал ўзлаштирган, салохиятли хамда замон талабларига мос лингвистик ва маданий компетенцияларга эга малкакали гид-таржимонлар фаолияти мухим ўрин эгаллайди. Хозирги кунда туризм сохасидаги мақсадли дастурларни амалга ошириш бўйича гид-хамрохлик қилувчи мутахассисларни тайёрлаш борасида юртимизда талайгина ишлар амалга оширилмоқда. Замон талабига кўра махсус гид-таржимонлар тайёрлаш таълим йўналишларининг очилганлиги фикримиз далилидир.

Туризм сохасида кадрлар тайёрлаш ва уларни қайта тайёрлаш, шунингдек, уларнинг малакасини ошириш, шу жумладан сохавий хорижий ўқув марказларида ва таълим муассасаларида стажировкалардан ўтиш масалаларига алохида эътибор қаратиш лозим. Ўзбекистоннинг туризм салохиятини чет эл туризм бозорларида тарғибот қилиш мақсадида 
ташкилий ва реклама-ахборот тадбирларини амалга ошириш, шу жумладан, махаллий ва хорижий босма ва электрон оммавий ахборот воситаларида мақсадли рекламалар, мақолалар ва бошқа материалларни жойлаштириш каби вазифаларни амалга оширишда хам албатта, малакали хорижий тил мутахассислари асқотади.

Зеро, улар хорижий туризм ярмаркаларида, кўргазмаларда, лойихалар ва дастурларида қатнашиш жараёнида хорижий тил кўникмалари хамда соха бўйича олган билим ва малакаларига таяниши табиий. Уларнинг бундай лингвомаданий компетенциялари қуйидаги таълим факторлари тизими билан чамбарчас боғлиқ бўлиб, улар замонавий гид-таржимонлар салохиятини акс эттирувчи асосий омиллар бўлиб хисобланади.

Масалан, хорижий тил буйича мутахассислар, хусусан, таржимон ва гидхамрохлар ёки хорижий тил бўйича филологларга бакалавр даражасидаги таълим жараёнида турли хил лойихалар яратиш шароитини яратиш лозим. Яъни, таълимда туристик лойиха яратиш бўйича махсус курслар ёки алохида мутахассислик фани жорий этилиши мақсадга мувофиқдир. Бундай лойиха туризм сохасини ривожлантириш ва туризм сохаси мутахассисларининг лингвомаданий малакаларини юксалтириш хамда уларни замон талабига кўра шакллантириш, шунингдек, ушбу жараённи ахборот-коммуникацион технологиялар асосида инновацион ўқитиш метод ва технололгияларини ишлаб чиқиш ва уларни амалиётга жорий этиш каби долзарб масалалар ечимига ёрдам беради.

Шунингдек, бундай лойихалар келгусида талаба-ёшларни Республикамизда туризм сохасини ривожлантиришга, хусусан, гид-таржимонлар касбий махоратини оширишга ёрдам берадиган амалий ва назарий натижаларга эришиш имконини беради.

Бундан ташқари, бундай лойихалар бугунги куннинг долзарб масалалари ечимини топишга қаратилганлиги боис уларни ахборот технологиялари мутахассислари билан хамкорликда амалга ошириш хам таълимда яхши самара беради.

Яна шундай омилларлдан бири замонавий гид-таржимлонлар тайёрлаш жараёнида амалиётга алохида эътибор қаратиш лозим, яъни талабалар амалиётини махсус сайёхлик фирмалари билан тузилган шартномалар асосида амалиёт жараёнларини айнан сайёхларнинг энг гавжум пайтига мослаштирган холда амалга ошириш режасига эътибор қаратиш мақсадга мувофиқдир. Бунда талабаларнинг амалиёт жараёнлари асосан қуйидагиларни қамраб олиши зарурдир:

- сайёхлик фирмаларининг маъмурий иш юритиш жараёни билан яқиндан танишиш;

- сайёхларга гид-таржимонлик қилиш ишларида иштирок этиш;

- сайёхлик фирмаси сайтини турли хил тилларда янгилаб туришда таржима буйича кўмаклашиш ;

- хамкорликда расмий хужжатлар таржимасига доир ўқув-услубий сайёх тавсияномаларини тузиш ;

- таржимада аниқликка эришиш;

- Ўзбекистоннинг тарихий жойлари хақидаги маълумотлар базасини хорижий тилларда мукаммал ишлаб чиқиш.

Сайёхлик фирмалари эса, талабалар амалиётини ташкил этишда ўзаро хамкорлик асосида кўмаклашиши икки томонлама тузилган шартномалар ижросини тўла қонли таъминлашга ёрдам беради. Масалан, туризм сохасини узлуксиз ривожлантириш мақсадида сайёхлик фирмалари талабалар учун 
қуйидагича турли хил амалий тадбирларни амалга ошириши бу борадаги икки ёқлама харакатнинг бир хилда амалга оширишни таъминлайди:

- Гид таржимонлик сохасига оид семинарлар ва давра сухбатлар ўтказиш;

- Талабалар ўртасида гид таржимонлик сохасига бўлган қизиқишни ошириш ;

- Ёзги амалиёт курсларини хамкорликда ташкил қилиш ;

- Сайёхлик фирмаси муаммолари бўйича илмий-тадқиқот ишлари (магистрлик диссертацияси, битирув малакавий иш ва курс ишлари) олиб бориш имкониятини яратиш.

Таълимнинг бундай амалий шакли келгусида талаба-ёшларни туризм сохасига янада қизиқишини оширишга, қолаверса, Республикамизда туризм сохасини ривожлантиришга, хусусан, гид-таржимонлар касбий махоратини оширишга ёрдам беради. Бундан ташқари, таълимда бундай лойихалар асосида ўқитиш бугунги куннинг соха бўйича долзарб масалалар ечимини топишга қаратилган бир йўл сифатида хизмат қила олади.

\section{Адабиётлар :}

1. Ўзбекистон Республикаси Президентининг 2016 йил 2 декабрдаги ПФ-4861-сонли «Ўзбекистон Республикасининг туризм сохасини жадал ривожлантиришни таъминлаш чора-тадбирлари тўғрисида» номли Фармонига .https://lex.uz/docs/4143188

2.Ўзбекистонда туризмни

https://moluch.ru/archive/117/32279/

ривожлантириш

истиқболлари.

3. M.Abduvohidov, F.S.Qutlimurotov . TURIZM IQTISODI, darslik. -T., 2011.

\section{ОСОБЕННОСТИ СОЗДАНИЯ СВОБОДНОЙ ТУРИСТСКОЙ ЗОНЫ: АНАЛИЗ ТЕОРЕТИЧЕСКИХ АСПЕКТОВ}

\section{Алимова М.т. \\ доктор экономических наук, доцент, проректор по научным исследованиям, инновациям и коммерциализации МУТ «Шёлковый Путь» Аллаёров Р.A. \\ базовый докторант, СамИЭС}

Annotation: The article substantiates the scientific expediency of creating free tourist zones for the accelerated development of tourism in the country. Based on a theoretical analysis of scientific results, it is substantiated that the features of creating free economic zones of a tourist type depend on the level of socio-economic development of the country, the socio-economic situation, geographical and natural conditions, the country's place in the international division of labor and some other circumstances.
Key words : tourism infrastructure, free tourist zone, thematic clusters, tourism industry, analysis, problems, premises.

За последние десятилетия туризм превратился в одну из наиболее динамично развивающихся и прибыльных отраслей мирового хозяйства. На долю международного туризма приходилось около 10\% мирового ВВП, более $9 \%$ всех занятых в глобальной экономике 1 .Высокие темпы роста, способность к усилению деловой активности в смежных секторах экономики (строительство, транспорт и связь, торговля, финансы и т. д.), весомый вклад в повышение уровня занятости населения делают туриндустрию все более значимой отраслью национального хозяйства. 
Однако на сегодняшний день сфера туризма в Узбекистане еще не получила должного развития, на что указывает существенное отставание ее основных отраслевых параметров от аналогичных показателей ведущих экономик мира. Так, показатели, характеризующие долю занятых в сфере туризма $(2,7 \%)$ и ее вклад в структуру производства ВВП (менее 3,1 \%), уступают общемировым в 3-4 раза1. Обеспеченность гостиничным фондом, предприятиями общественного питания, качество предоставляемых туристам услуг в Узбекистане также значительно уступают уровню стран - лидеров мирового рынка туризма.

Туризм, являясь отраслью экономики, аккумулирует мощные финансовые потоки и вносит значительный вклад в региональную экономику, способствуя развитию региона. Развитие индустрии туризма оказывает стимулирующее воздействие на такие секторы экономики, как транспорт, связь, торговля, строительство, сельское хозяйство, производство товаров народного потребления. Это позволяет государству решить вопрос о пополнении- доходной части как республиканского бюджета, так и бюджетов других уровней.

Мировой опыт показывает, что эффективным механизмом реализации возможностей той или иной территории для развития туризма является организация туристских особых экономических зон. Туристские особые экономические зоны являются своеобразным катализатором инвестиционных процессов и обеспечивают технологическое обновление производства при одновременном усилении его конкурентоспособности как в экономически развитых странах, так и в странах с переходной экономикой. В Узбекистане подобный опыт еще не получил широкого распространения.

Основные, цели создания свободных экономических зон туристского типа следующие:

- обеспечение за счет создания свободных экономических зон диверсификации экономики региона;

- стимулирование развития депрессивных регионов с низким промышленным потенциалом;

- повышение занятости населения;

- улучшение здоровья и качества жизни населения за счет роста доступности получения гражданами страны туристских и санаторно-курортных услуг;

- рост туристских потоков;

- сохранение окружающей среды, природных и культурных ценностей;

- развитие инженерной; транспортной и социальной инфраструктуры.

Туристские особые экономические зоны - не новое явление в мировой, практике, функционирования разнообразных особых экономических зон. В 120 странах насчитывается свыше трех тысяч различных СЭЗ с годовым оборотом 600 млрд. долл. В историческом плане, процесс анклавизации (enclavisation) туристической отрасли, то есть выделения специальных туристических зон на территории того или иного государства, начался с середины 1960-х годов в период активной деколонизации в мире. Экономический рост, охвативший страны Западной Европы, США в послевоенное время, способствовал образованию широкой прослойки людей с высокими доходами и потребностью к отдыху и путешествиям. В то же время во всем мире стали возникать новые независимые государства из числа бывших европейских колоний. Эти страны, еще недостаточно развитые в экономическом плане, оказались идеальными площадками для формирования туристско-рекреационной индустрии. ${ }^{2}$

${ }^{1}$ www.wttc.org 
Изначально, процесс анклавизации туристической отрасли был поддержан мировыми финансовыми институтами (Всемирный банк, Международный валютный фонд), предоставлявшими заемные средства властям вновь возникших государств для организации специальных зон развития туризма, объясняя, необходимость их создания тем, что они позволят создать новые рабочие места и привлечь инвестиции. Первые туристские анклавы появились в Египте, Тунисе, Марокко, Мексике, Индонезии, Кении, Танзании, Гамбии, островных странах Карибского бассейна (Ямайка, Барбадос и др.). В них приезжали туристы преимущественно из европейских стран (Великобритании, Франции, Голландии, Испании, Германии, Португалии), а также Японии и США.

Следует отметить, что на сегодняшний день в Узбекистане уделяется особое внимание развитию свободных экономических зон как важного фактора привлечения иностранных инвестиций, прежде всего прямых, для создания современных высокотехнологичных производств, обеспечивающих выпуск конкурентоспособной продукции с высокой добавленной стоимостью на базе углубленной переработки местных минерально-сырьевых ресурсов, комплексного и эффективного использования производственного и ресурсного потенциала регионов республики, создания на этой основе новых рабочих мест и повышения доходов населения.

Создана прочная законодательная и нормативная база, регламентирующая деятельность СЭ3, сформирована широкая система налоговых и таможенных льгот и преференций, способствующая привлечению в развитие СЭЗ как иностранных, так и отечественных инвестиций. В настоящее время функционируют 17 СЭЗ (СЭЗ «Джизак» ${ }^{1}$, СЭЗ «Ангрен» ${ }^{2}$, СЭЗ в Навоийской области ${ }^{3}$, СЭЗ «Ургут», СЭЗ «Гиждуван», СЭЗ «Коканд», СЭЗ «Хазарасп»4, СЭЗ «Нукус-фарм», СЭЗ «Зомин-фарм», СЭЗ «Косонсой-фарм», СЭЗ «Сирдарё-фарм», СЭЗ «Бойсун-фарм», СЭЗ «Бустонлик-фарм», СЭЗ «Паркент-фарм» ${ }^{5}$, СТЗ «Чарвак» 6 , СЭЗ «Сирдарё»7, СЭЗ «Спорт» 8 , СЭЗ «Балик ишлаб чикарувчи»9 ) и одна СТ3 «Чарвак».

В частности, при создании зон касающихся туристической сферы, справедливо учесть ряд условий, созданных в последнее время, т.е. Постановление Кабинета Министров Республики Узбекистан «Об организационных мерах по реализации проекта «строительство туристской зоны «Кадимий Бухоро»» (№ 825 от 14 октября 2017 г.) и Постановление Президента Республики Узбекистан «О мерах по созданию туристской зоны «Эски Шахар» в городе Ташкенте» (№ ПП-3260 от 7 сентября 2017 г.). Данные указания были установлены в целях дальнейшего повышения туристского потенциала республики, в частности развития туристской отрасли с использованием имеющихся ресурсов. Еще одним из актуальных задач страны можно считать Постановление Кабинета Министров Республики Узбекистан «0 мерах по организации деятельности свободной туристской зоны «Чарвак»» (№ 365 от 15 мая 2018 г.). на основании Указ Президента Республики Узбекистан «0 создании свободной туристской зоны «Чарвак» (№ УП-5273 от 5 декабря 2017 г.).

В процессе исследований нами были изучены ряд научных трудов зарубежных ученых по международным базам научных исследований, таких как SCOPUS, 
ScienceDirect, WebofScience и т.п. На первом этапе мы постарались сгруппировать научные результаты отражающие, как теоретико-методологические основы деятельности СЭЗ и зарубежный опыт их создания, так и специфику СЭЗ туристского типа.

На 22-ой международной экономической конференции IECS 2015 ученые во главе Л.Франтишека обратили внимание на основные принципы создания объектов особой экономической зоны, в частности применение кластерного подхода при формировании СЭЗ, а также подчеркнули в нем использование оптимальных производственных коммуникаций, которые обеспечивают устойчивое развитие с учетом экологических, экономических и социальных факторов [1].

Китайский ученый Дж.Вонг предлагает руководствоваться основами концептуальной политики экономической зоны, т.е. учитывать результаты:

во-первых, увеличение прямых иностранных инвестиций в объеме $58 \%$ на душу населения за счет экспорта;

во-вторых, рост внутренних инвестиций страны;

в-третьих, увеличение темпов роста общей производительности, т.е. прирост производства на 0,6 процентных пункта с учетом деятельности СЭ3 [2].

Он считает, что принятие во внимание вышеизложенных условий и их реализация, приведет к увеличению значимости, особенно экономической эффективности СЭЗ.

В 2011 году М.Ливейн в своей статье по вопросам юридических прав на собственность при СЭЗ предлагает обратить внимание на ее экстро экономический процесс, который требует устранения дисбаланса в деятельности всех участвующих хозяйствующих структур, т.е. субъектов экономической сферы [3].

В своем научном исследовании П.Пакденурита обращает особое внимание возможностям специальных экономических зон, с учетом специфики, касающихся развивающихся стран [4].

Среди ученых стран СНГ большинство научных исследований направлено на изучение методологических подходов совершенствования свободных туристских зон. Например, Л. И. Поройко в своих исследованиях обращает внимание на кластерный метод при развитии туристско-рекреационных зон [5].

Вавилонская Т.В. рассмотрела структуры туристско-рекреационных комплексов (ТРК), где представлены результаты анализа мировой практики проектирования ТРК. А также в научных трудах показана взаимосвязь местоположения рекреационных территорий и урбанизированных систем; для каждого случая подсчитано функциональное наполнение комплекса и его процентное соотношение, где выявлены два принципиальных композиционных приема проектирования ТРК [6].

В научных исследованиях доктора экономических наук Ерохиной В.Е. проводится обзор и анализ практики становления и развития территорий с особым экономическим статусом, в том числе специальных (особых) экономических зон (СЭ3), наукоградов, территорий опережающего развития [7].

Из отечественных ученых занимающихся изучением специфики свободных туристских зон, является Халим Хамраев. Главная цель его исследований - оказание услуг туристическо-рекреационного характера, а также эффективное использование потенциала региона для активизации внешнеэкономических связей. Он считает, что создание таких туристических зон в Узбекистане даёт большое преимущество для развития экономики, так как туризм является для республики перспективной отраслью экономики [8].

Нами было выявлено, что в большинстве научных исследованиях изучены специфические особенности экономических зон, с учетом возможностей 
формирования при экономических и юридических условиях, в частности в развивающихся странах. Мы согласны, что для развития национальных экономик развивающихся стран при создании СЭЗ государством отводится важная роль в реализации преследуемых целей и задач, решаемых в экономическом и социальном развитии. Цели, преследуемые странами, образующими СЭЗ, зависят от уровня их экономического развития, социально-экономической ситуации, географических и естественных условий, их места в международном разделении труда и ряда других обстоятельств.

\section{Литературы:}

1. Туристско-рекреационные зоны: оценка социально-экономической эффективности в условиях современной российской экономики. Л.И.Поройко // Вопросыпредпринимательстваиэкономики, № 4, 2013 г.

2. The Economic Impact of Special Economic Zones: Evidence from Chinese Municipalities. Jin Wang. Hong Kong University of Science and Technology This Version, Sept, 2010

3. Special Economic Zones and Accumulation by Dispossession in India. Michael Levien // Journal of Agrarian Change, Vol. 11 No. 4, October 2011, pp. 454-483

4. Special Economic Zone: Facts, roles, and opportunities of investment. Pakdeenurit, P.A., Suthikarnnarunai N.B, Rattanawong W.A. Lecture Notes in Engineering and Computer Science, January, 2014

5. Туристско-рекреационные зоны: оценка социально-экономической эффективности в условиях современной российской экономики. Поройко Л.И. // Вестник академии. №4-2013 (38). http://www.vestnik-mosap.ru/

6. Принципы проектирования туристско-рекреационных комплексов в условиях свободной экономической зоны. Вавилонская Т.В. // Вестник СГАСУ. Градостроительство и архитектура, 2014, № 2 (15). С. 6-12

7. Влияние территорий с особым экономическим статусом на пространственное развитие регионов. Ерохина Е.В. // Национальные интересы: приоритеты и безопасность 2015, № 36 (15). С. $12-29$

8. Концепция создания туристической экономической зоны “БУХОРО”. Х.Хамраев // ALATOO ACADEMIC STUDIES. 2016. № 2, C. 231-235

\section{ТУРИЗМНИ РИВОЖЛАНТИРИШДА МУЗЕЙЛАРНИНГ ЎРНИ (Самарқанд вилоят Ўлкашунослик музейи мисолида)}

\section{Ўринбоева Мўътабар Якубовна, Самарқанд вилоят ўлкашунослик музейи бўлим мудири}

Annotation: The article deals with work in the tourism sector in our country and the role of museums in this. At the same time, it contains information about rare exhibits and exhibitions stored in the Samarkand Regional Museum of Local Lore. In addition, the article discusses the ways and prospects of development of the cultural and tourist spheres, in particular, museums.

\section{Key words :} tourism in our country, rare exhibits and exhibitions, museum of local lore, tourist spheres, history of Bukhara Jews, portable exhibition, architecture.

Бугунги кунда юртимиз жадал суръатлар билан ривожланиш, дунё меъморчилик талабларига тўла мос келадиган янгидан-янги бинолар, шахарлар, қишлоқлар бунёд этилмоқда. Нафақат архитектура ва қурилиш сохаси балки қолган барча сохалар хам ривож топиш қаторида, туризм сохасида хам кўплаб янгиликлар Президент қарор ва фармонлари, режалар амалиётга тадбиқ қилинмоқда. Жумладан, Ўзбекистон Республикаси Президентининг "Ўзбекистон Республикасининг туризм сохасини жадал ривожлантиришни таъминлаш чора-тадбирлари тўғрисида" 2016йил 2-декабрдаги ПФ-4861-сонли Фармон хамда "Ўзбекистон Республикаси 
туризмни ривожлантириш давлат қўмитаси фаолиятини ташкил этиш тўғрисида"ги, 2018-йил 3-февралдаги ПФ-5326-сонли Фармони, ички туризмни жадал ривожлантириш, фуқароларни мамлакатимизнинг маданий-тарихий мероси хамда табиий бойликлари билан таништириш мақсадида “Ички туризмни жадал ривожлантиришни таъминлаш чора-тадбирлари тўғрисида" 2018-йил 7-февралдаги Пқ-3514-сонли қарорлари, Республиканинг туризм салохиятини, сохага инновацион ғоя ва технологияларни жорий этиш, шунингдек мамлакатнинг бой табиий, маданий ва тарихий меросининг мавжуд ресурслари ва имкониятларидан хар томонлама фойдаланиш хисобига ривожлантириш учун янада қулай шароитлар яратилмоқда[2,208]. Ўз навбатида 2020-йил 26-майда қабул қилинган “Ўзбекистон Республикаси Маданият вазирлиги фаолиятини такомиллаштириш чора-тадбирлари тўғрисида"ги ПҚ-4730-сонли қарори маданият ва санъат сохаси учун дастурамал бўлиб хизмат қилади. Шунингдек, 2020-2025 йиллар давомида мамлакатимизнинг хар бир туман ва шахрида Ўлкашунослик музейларини ташкил қилиш белгиланди. Бу республикамизнинг барча худудларида мавжуд бўлган тарихий ашёларнинг музейларда тўпланишини тезлаштиради. Бундан ташқари, хар бир худудда яшаётган ахоли ўртасида ўзи яшаётган макон табиати, тарихи, илм-фани, маданияти ва санъати тўғрисида маълумотларни билишга замин яратади.

Мамлакатимизда халқимизнинг тарихий, илмий ва маданий мероси, маънавий қадриятларини ўзида асраб келаётган 130 га яқин музейлар фаолият кўрсатмоқда. Музейлар юртимиз табиати, ривожланиш тарихи, маданияти, ижтимоий-маданий сохаларда эришган ютуқлари хақида хикоя қилувчи ўзига хос маскан бўлиб, Ўзбекистон Республикасининг “Музейлар тўғрисида"ги қонуни асосида музейлар фаолиятини қўллаб-қувватлаш ва такомиллаштириш, сақланаётган ноёб экспонатларни асраб-авайлаш, ўрганиш ва тарғиб этишга хизмат қилиб келмоқда. Бу борада Самарқанд давлат музей-қўриқхонаси тасарруфидаги Самарқанд вилоят ўлкашунослик музейи хам алохида ўрин эгаллайди. Музейга 1896-йилда асос солинган. 1981-йилдан музей Самарқанд вилоят ўлкашунослик музейи деб атала бошланди.

Самарқанд вилоят ўлкашунослик музейи Чор Россиясининг бадавлат савдогарларидан бири Абрам Қалантаровга тегишли бўлган тарихий бинолардан бирига жойлашган. Ховли тўрида, таниқли рус меъмори Е. Нелле лойихаси асосида қурилган, XX аср меъморчилигига хос бўлган эклектик услубдаги икки қаватли бинода жойлашган. Ховлида 1902-1916 йиллар давомида бешта бино қад кўтарган. Айни вақтда ушбу бино давлат меъморий ёдгорликларни сақлаш идораси химоясига олинган. Самарқанд вилоят ўлкашунослик музейининг хилма-хил коллекциялар асосини Зарафшон вохасининг турли худудларидан топилган қадимдан то XX асрнинг бошигача хикоя қилувчи тарих бўлимига оид ва тарихий археологик ашёлар ташкил этади.

Музей жойлашган бино хўжайини Абрам Қалантаровнинг мехмонхоналари ўша даврга мослаштириб қайта жихозланган, унинг кабинети, кичик ва катта мехмонхоналари, Наполеон даври мебеллар жамланмаси, Германия фирмаси томонидан ишлаб чиқарган плиткалар билан қопланган камен печлари, Варшава қандили, Венеция кўзгулари олиб келиб ўрнатилган. Музейнинг кириш дарвозаси хам ўзига хос хуснга эга бўлиб, дарвоза махсус буюртма асосида Россияда юқори сифатли рехта темиридан ясалган бўлиб, панжарали, темир гуллар билан безатилган ва келтириб ўрнатилган. Самарқанд давлат музей-қўриқхонаси, Бухорий яхудийлари Самарқанд бўлими ва АҚШнинг «Джойнт» номли яхудий ташкилоти Самарқанд вилоят ўлкашунослик музейи биносида Ўзбекистоннинг бухорий яхудийлари тарихи ва хозирги хаёти хақида хикоя этувчи кўргазма ташкил этилиб, яхудийлар маданияти ва тарихини тўла-тўкис ифодалаб туради[1,41]. 
Музейнинг фондлари хамиша тўлдирилиб турилиб, музей экспонатлари вақтивақти билан экспозицияга намойиш учун қўйилади. Музейида вилоятимиз худудидан топилган ноёб экспонатлар кўргазмалари ташкил қилинган. Бу эса “Жавохирлар сандиғи” хисобланган музей ашёларини томошабинларга яқиндан таништириш имконини беради.

Музейда сақланаётган турли даврларга оид бўлган тарихий ашёлар, яхудийлар маданиятига оид ашёларни кўришга, ўрганишга чет эллик сайёхлар ўртасида хам қизиқишлар жуда каттадир. Музей хозирда Самарқанд вилоятнинг энг сергавжум масканларидан бири бўлиб, айниқса Исроил, Корея, Хитой, Россия, Япония каби бир қатор давлатлардан чет эллик сайёхлар ташриф буюришади. Музей ва туризмнинг уйғунлиги махаллий ва чет эллик сайёхларга маънавий озуқа бериш билан биргаликда, тарихий ва маданий меросимиз билан яқиндан таништиришга имкон яратади. Бу турдаги туризмни йўлга қўйиш учун нафақат чет давлатлар билан балки ички туризмга юртимиздаги барча ташкилотлар ва таълим муассасалари билан хамкорлик шартномаларини тузиб, кўргазмалар ва кўчма кўргазмалар, қизиқарли тадбирлар, мусиқий кечалар ташкил этиб томошабинларни жалб қилиш мумкин.

Халқаро туризм сохасида малакали кадрлар тайёрлаш тизимини ташкил этиш хамда илмий-тадқиқот ишлар ва ижодий ишлар олиб бориш мақсадида 2018-йил 28-июнда Ўзбекистон Республикаси Президентининг қарорига мувофиқ Самарқандда “Ипак йўли халқаро тузим университети" ташкил этилди. Хозирда ушбу университет профессор-ўқитувчилари музей ходимлари хамкорлигида талабалар билан мавзувий дарслар ва амалий машғулотлар олиб бормоқдалар.

Хулоса қилиб айтадиган бўлсак, махаллий ва хорижий сайёхларни жалб қилиш борасида юртимизнинг туристик салохият етарли даражада бўлиб, туризм сохасига берилаётган эътибор унинг ривожланишида мухим ўрин тутади. Бу имкониятлардан тўғри фойдаланиб, туристик имкониятларимизни чет давлатларга тарғиб қилиш орқали юртимизга ташриф буюрувчи туристлар сонини ошира олсак мақсадга мувофиқ бўлади. Бу давлатимиз давлат буюджетини тўлдириб, халқимизнинг фаровон хаёт кечиришига ёрдам беради.

\section{Адабиётлар:}

1. Самарқанд давлат музей-қўриқхонаси. Самарқанднинг тарихий обидалари ва музейлари. Самарқанд. 2010, -41 б.

2. Маданиятлараро мулоқот Ўзбекистон туризм нигохида: Тажриба, долзарб муаммолар ва истиқболлар. Халқаро илмий амалий анжуман материаллари. Самарқанд. 2019, -209 б.

\section{ХОРИЖИЙ САФАР ВА САЁХАТЛАРНИНГ МАДАНИЯТЛАРАРО МУЛОҚОТГА ТАЪСИРИ ХУСУСИДА (Самарқанд жадидлари ижоди мисолида)}

\section{Жахон иктисодиёти ва дипломатия университети докторанти}

Annotation: The article is devoted to the influence of foreign travels and travels on intercultural dialogue in the work of Central Asian Jadids.

Мамлакатда туризмни, миллий иқтисодиётни диверсификация қилиш, худудларни жадал ривожлантириш, янги иш ўринларини яратиш, ахолининг даромадлари ва турмуш даражасини ошириш, мамлакатнинг инвестициявий жозибадорлигини оширишни таъминловчи стратегик тармоқлардан бири сифатида 
ривожлантириш бўйича комплекс чора-тадбирлар босқичма-босқич амалга оширилмоқда.

Шу маънода XIX аср охири - XX аср бошлари Самарқанд зиёлилари чет эллик сафарлари ва саёхатларининг маданиятларо мулоқотларга таъсирини ўрганиш мухим ахамият касб этади.

Саёхатнома маълум бир жанр, саёхат таассуротлари ва тафсилотлари тасвирига бағишланган acap. Саёхатномаларнинг тарихий-бадиий қиймати муаллифнинг мақсади, услуби ва махоратига боғлиқ. Адабиёт тарихида саёхат таассуротларининг насрий ва шеърий тасвиридан иборат ўнлаб асарлар мавжуд. Насрий саёхатномаларда жой ва воқеаларнинг изчил тафсилоти етакчи ўрин тутса, шеърий саёхатномаларда тасвир ихчам ва умумлашма характерда бўлади.

Таниқли жадидчи олим Бегали Қосимовнинг ёзишича, Русия Туркистонга келар экан, у билан бирга, табиийки, европача тартиблар хам (давлат юритиш, маориф тизими, харбий ишлари, маданий-маиший қурилмалар, савдо-саноат каби) кириб келди. Хусусан, театр, матбуот, гимназия кабилар неча асрлардан буён турғунликда келаётган Туркистон халқида катта таассурот қолдирди. Рус маъмурияти махаллий зиёлилардан вакиллар танлаб, уларнинг Москва, Петербургга саёхатини уюштирди. Бир қисмини зодагонларнинг ички хаётига олиб кирди. Турли-туман кўргазмалар уюштирди. Ва булар, табиийки, ўз самарасини берди. Адабиётда Русия мавзуи, рус илм-фани, маданияти-маорифи тарғиби пайдо бўлди [9].

Ўзбек маърифатпарвар адиблари ўзларининг саёхат хотираларида жанрнинг қоидаларига тўлиқ амал қилдилар: китобхон учун қизиқарли бўлган этнографик материаллар, ўзлари бўлган ўлкалардаги таълим тизими, маданият, халқнинг турмуш тарзи, машгулотлари, ижтимоий-иқтисодий ахволи ва хоказолар хақида хикоя қилдилар [11].

Махмудхўжа Бехбудий хаж сафарида бўлган чоғида Арабистон, Миср, Туркияни кезиб чиққан (1899-1900). Саёхат давомида янги мактаб (усули жадид) очиш истаги мустахкамланиб борди.

Бехбудий 1914 йилда иккинчи марта араб мамлакатларига саёхатга чиқади. Саёхати давомида Россиянинг кўпгина шахарларида бўлади, ва июн бошида Туркия пойтахти Истанбулга келади. Ундан Аданага ўтиб, яна Истанбулга қайтади ва 20 июнда Исмоилбек Гаспринский билан учрашади.

Сўнг Бехбудий Қуддус, Байрут, Ёфа, Халил ар-Рахмон, Порт-Саид, Шом шахарларида бўлади. Саёхат хотиралари Самарқанд журналида чоп этилади. Муаллиф унда йўл таассуротларига, кишилар билан учрашувларининг ибратли томонларига кенг ўрин беради, шахарлар тарихи, обидалари, буюк зотлари хақида маълумотлар тўплайди, миллатлар, уларнинг урф-удумлари, турмуш маданияти билан қизиқади, дин, эътиқод масалаларига катта ахамият беради [1].

Олмон олимаси Ингеборг Балдауфнинг «Махмудхўжа Бехбудий Фаластинда» мақоласида шундай фикр бор: «Бехбудий ўқувчиларга Фаластинда яшовчи араб мусулмонларининг тақдирини намойиш этади»[5].

Хожи Муин 1922 йили «Туркистон» ва «Зарафшон» газеталарида эса шундай хулоса қилади: «Бехбудий афанди керак матбуот воситаси билан ва керак Туркистон ўлкасининг каттарак шахарларида килғон саёхатлари билан халқимизга янги фикрлар берган ва шунинг билан ўзига анча мухлислар пайдо қилган эди» [10].

Жадид етакчиларининг барча ўлкаларга сафар қилишидан иккита мақсади бўлган: биринчиси - янги усулдаги мактаблар очишни ташкил этиш, иккинчиси ўз прогрессив ғоялари тарқалиши билан боғлиқ масалалар. Туркистон зиёлилари 
Шарқ ва Ғарб мамлакатларига қилган саёхатлари пайтида у ерлардаги ўзгаришларни кўрганлар ва бу улар фаолиятига таъсир кўрсатган.

«Узун тартибсизликлар орқасида бузулган, биткан ўлкамизнинг оқибат ўлдиргувчи истибдод идораси остида ижтимоий ва иқтисодий хаётимиздаги пастланиш адабиёт тарихимизда очиқ сезиладир. Чунки тарихимизнинг хеч бир даврида иқтисодий ва ижтимоий холимиз бу қадар пастланган даври йўқдир», [2] деб таъкилайди Вадуд Махмуд.

Саидризо Ализода таъкидлаганидек, таълим сиёсатини тўғри йўлга қўйиш давлат, жамият, иқтисод ва маданиятнинг тараққиётига муайян даражада ижобий таъсир кўрсатиши аниқдир. “Аммо биз Туркистон мусулмонлари, - деб ёзган эди С.Ализода, - наинки жадида мактаб ва мадраса очаяпмиз, балки ханузгача, уларни бидъат ва харом санаяпмиз. Билмайман, биз Туркистон мусулмонларига нима бўлган?», [3] - дея, бонг ўрган эди. Самарқанд жадидлари орасида Хожи Муин ўз эътиборини долзарб ижтимоий масалаларига қаратди, ўзининг асарларида долзарб социал муаммоларини ёритишга ва уларнинг ечимини топишга харакат қилган. "Халқнинг олдин бориши, юртнинг тинчланмоғи ва кучли бўлмоғи маориф, аскарлик, иқтисод ва дехқончилик ишларининг тузук бирбирига қўйилиши билан бўладурким, маалтаассуф, бу тўғриларда хануз халқ учун фойдали ва кўзга кўринурлик ишлар қилинғон эмас» [4]. Ёш авлод, энг аввало илм-фан тараққиётидан хабардор бўлишини ўзининг содда ва тушунарли тилда ўша даврдаги самарқандлик жадидлардан Исматулла Рахматуллаев ўзининг педагогик фаолиятида ёшларга таълим берди [5].

Миллий уйғониш (жадид) адабиётида кўтарилган муаммолар ва мавзуларни ўрганиб, улар билан XVIII аср Ғарбий Европа маърифатчилик адабиёти ўртасидаги муштаракликларни кузатиш мумкин. Бу адабиётлар ўртасидаги ўхшашликлар халқ орасида онг, билим, маънавият ва маърифатни тарғиб қилишда айниқса, яққол намоён бўлади. Марказий Осиё жадидларининг саёхат хотираларида асосан чет мамлакатлар халқлари хаётидаги ижобий томонларини тасвирладилар, халқимизнинг маданий-маърифий савиясини ошириш учун ўзбек газетхонлари ва китобхонларини улардан ўрганишга, ибрат олишга ва янгиликларни хаётга тадбиқ қилишга чақирдилар хамда бу ишда ўзлари етакчи бўлдилар. Хозирги давр адиблари ва публицистларининг турли мамлакатларга қилган сафарлари натижасида хам бир қатор насрий саёхатномалар юзага келди. Улар услубида очерк ва публицистика учун характерли хусусиятлар кўпроқни ташкил этади.

\section{Адабиётлар:}

1. Қосимов Б. Махмудхўжа Бехбудий (1875-1919)//«Ziyo.uz»кутубхонаси -http://n.ziyouz.com.

2. Вадуд Махмуд.Турк шоири Ажзий // Инқилоб.- 1924.- №11-12.

3. Фарход Ализода. Сайид Ризо Ализода. Тарихий - библографик очерк. - Тошкент. 2011.

4. Х Хожи Муин. Танланган асарлар. - Тошкент, 2010.

5. Ашурова Х.C. Самарқанд жадидларининг ижтимоий-сиёсий қарашлари (XX асрнинг биринчи чораги). - Самарқанд, 2020.

6. Улуғбек Долимов. Жахонгашта ижодкор // Жахон адабиёти. - 2015. - №10.

7. Бегали Қосимов. Абдурауф Фитрат(1886-1938)//«Ziyo.uz»кутубхонаси- http://n.ziyouz.com.

8. Шерали Турдиев. Хаётбахш алоқалар (ўзбек ва турк адабий алоқаларининг ривожланиш тарихидан) // Жахон адабиёти. - 2011. - №1.

9. Бегали Қосимов. Хулоса // «Ziyo.uz» кутубхонаси - http://n.ziyouz.com.

10. Бойбўта Дўстқораев, Нилуфар Намозова. Бехбудийнинг муносиб шогирди // «Ziyo.uz» кутубхонаси - http://n.ziyouz.com.

11. Nuriddinova D.K. G'arbiyYevropaadabiyotida "Sayoxatnoma" janrining ma'naviy-ma'rifiy xususiyatlari. - Namangan, 2014.

12. Абдивохидов С.А. Жадидчилик харакатининг ижтимоий-сиёсий жихатлари ва хозирги замон. - Самарқанд, 2020. 


\section{ДИНИЙ БАҒРИКЕНГЛИК ЎЗБЕК ТУРИЗМ МАДАНИЯТИНИНГ МУХИМ ОМИЛИ СИФАТИДА}

\section{Хакимов Эркин Тўйчиевич \\ Фарғона Давлат Университети доценти (Ўзбекистон) \\ Мирзарахимов Бахтиёр Хошимович \\ Фарғона Давлат Университети ўқитувчиси (Ўзбекистон) \\ E-mail: alfargoniy.uz@gmail.com}

Annotation: The article describes the factors of tourism Key words: development through the long-standing traditions and customs of the hospitality, religious Uzbek people. Recommendations are given for the development of tolerance, Islamic culture, tourism culture in Uzbekistan through national values pilgrimage etiquette

Ўзбекистонда азалдан турли урф-одат, маданият, тил,турмуш тарзига эга бўлган, хилма-хил динларга эътиқод қилувчи бир-бирига ўхшаш бўлмаган бир нечахалқлар яшаган ўлкадир. Ўзбекистон Буюк ипак йўли чоррахасида жойлашгани, кўплаб давлатлар билан иқтисодий, маданий алоқалар ерли халқнинг диний ва маданий хаётига катта таъсир кўрсатган. Миллати ва диний қарашидан қатъий назар, мехмондўстлик, инсонни ардоқлаш ва ўзгаларни қадрлаш,катталарга хурмат ва бошқаларни иззат қилиш каби туйғулар Марказий Осиё халқларининг юксак сифатларидир. Айнан шу омиллар халқимизнинг нафақат маънавий-маърифий, балки диний бағрикенглигинингмаънавий асосини ташкил этади. Бу сифатлар бугунги кунда хам давом этиб келмоқда. Бунинг натижасида, бугунги кунда, Ўзбекистонда хам диний туризм, айниқса, бошқа динлар муқаддас қадамжоларига бўлган қизиқиш туристларда ортиб бормоқда.

Ўзбекистон замини илк диний қараш ва тасаввурлар пайдо бўлган энг қадимий ўлкалардан бири сифатида кўплаб тарихий манбаларда зикр қилинган. Қадим замонларданоқ минтақада зардуштийлик, буддавийлик, яхудийлик, насронийлик каби мураккаб идеологик тизимга эга динлар тинч-тотув фаолият олиб боришган. Тешик-Тош ғорларидаги қадимий қабрлар, Фаёзтепа, Қоратепадагибуддавийлик топилмалари, вапроқалъа Қўйқирилганқалъаёдгорликларидаги зардуштийлик ибодатхоналари, бугунги кунда япон ва француз археологлари мехнати натижасида аллақачон туристларнинг севимли масканларига айланиб улгурган.

Хитойлик Сюань-Цзянь берган хабарга кўра, VII асрнинг бошларида Термизда 10 та буддавийлик хонақохи ва мингта рохиб фаолият олиб борган. Ўзбекистонда диний бағрикенглик ва муросанинг илдизлари узоқ асрларга бориб тақалади. Ўзбекистонда фаолият кўрсатган турли динлар маданияти бўйича изланишлар олиб бораётган япон олими Като фикрига кўра, Сурхондарё вохасида аниқлаган ноёб Будда маданияти ёдгорликлари, яхудий ёдгорликлари, Бухорода насронийларнинг зиёратгохлари юртимиздаги ислом обидалари билан бир қаторда туриши хеч кимни ажаблантирмайди, деб таъкидлаганда шубхасиз адашмаган.

Академик В.Бартольднинг фикрича, VI асрда Самарқандда христиан епископи ва бевосита араблар келишидан олдин эса митрополити бўлган. Хозирги Тошкент ва Хоразм вилоятлари худудида хам христиан динига мансуб ахоли мавжуд эди. Бугунги кунда, Ўзбекистон худудидаги христиан дини билан боғлиқ черковлар асосан Чор Россияси босқинидан кейин бунёд этилган бўлсада, лекин христиан дини хам бошқа динлар сингари бу худудда узоқ ўтмишга эга. Шуни инобатга олиб асосан Ўзбекистонга ташриф буюрадиган сайёхларнинг асосий қисмини 
Европаликлар ташкил этишини хисобга олган холда христиан дини билан зиёратгохларни хам туризм маршрутларига киргизиш зарур.

“Тинчлик шахри”, “Дўстлик шахри”, “Жасорат шахри”, “Нон шахри”, “Боғроғлар шахри”, “Шарқ дарвозаси” сифатида машхур Тошкент шахрига 2007 йили “Тошкент - ислом маданияти пойтахти” деган юксак ном берилди, Ислом хамкорлик ташкилоти хұар йили мусулмон мамлакатларидаги 3 та шахұарни Ислом маднияти пойтахти деб эълон қилади. Уларнинг бири Араб мамлакатларидан, бошқаси Осиё ва учинчиси Африкадаги мусулмон мамлакатларидаги шахарлардир. Ташкилотдаги мадният вазирлиги IX ислом конференсияси томонидан 2020 йилда Бухоро, Қохира (Миср) ва Бамако (Мали) шахарлари Ислом маданияти пойтахти сифатида тасдикланган.[2].

Ўзбекистон Республикасида диний бағрикенглик тамойиллари асосида мамлакатда тинчлик ва тотувликни таъминланганини жахон хамжамияти томонидан тан олинганлигининг юксак ифодасидир.

Бугунги кунда эътиқоди, қайси дин вакили бўлишидан қатъий назар турли диний қарашлар, анъана ва қадриятларини ўз кўзлари билан кўришга бўлган интилиш рухий сокинликка эришишга бўлган интилиш, диний бағрикенглик тамойиллари авж олиб бормоқда. Ер юзи ахолисининг асосий қисми христиан, ислом, буддавийлик каби динлар билан бир қаторда турли миллий динларга хам сиғинишади. Бундан ташқари аждодлари томонидан муқаддас саналган диний қарашлар хам дунё халқлари томонидан муқаддас қадрият даражасида кўтарилган. Жумладан, Жанубий Американинг Мексика ва Бразилия ахолиси асосан христиан динига эътиқод қилсаларда қадимдан шу худудларда истиқомад қиладиган махаллий халқларнинг ибтидоий диний қарашлари ва маросимлари турли давлатлардан ташриф буюрадиган сайёхлар учун эгзотик туризм тури сифатида эътироф этилади. Махаллий хинду қабилаларининг анъана ва қадриятларини ривожлантириш ва асраб қолиш мақсадида мунтазам равишда турли фестиваллар карнаваллар ташкил этишга алохида ахамият бериб келинмоқда.

Ёшларни муқаддас қадамжолар хақидаги аждодларнинг турли қарашларини муқаддас қадрият сифатида келажак авлодга етказишда хам туризмнинг урни беқиёс хисобланади. Жумладан, муқаддас қадамжоларга ёш авлодни ташрифи ўз навбатида ёшлар ва кекса авлод ўртасидаги мулоқот майдони вазифасини ўтаб, муқаддас қадамжолар уларнинг тарихи, анъана ва қадриятлар, зиёрат одоблари, маросимлар хақида қимматли маълумотлар олиш билан бирга уларнинг маънавий дунёқарашини кенгайишида хам мухим ахамиятга эга.

Туризм инсонни дунёқарашини ўсишига, турли касалликлардан фориғ бўлишига, маънавий етукликка эришишда катта ахамият касб этади. Бугунги кунда, Ўзбекистон Республикасида ички туризм ривожланиш жараёнларига қарайдиган бўлсак хам, зиёрат туризми, яъни диний туризм етакчилик қилаётганлиги, бу ўз навбатида халқимизнинг бу борадаги диний қарашлари билан боғлиқ эканлиги билан ифодаланади.

\section{Адабиётлар:}

1. Дервиш Р.А., Левтеев Л.Г., Мусакаева А. Памятники истории религии и культуры в Узбекистане. - Т.: Ўқитувчи, 1994. - С.10-12, 56-60.

2. http://islom.ziyouz.com/ 


\section{TA'LIM MUASSASALARIDA TURIZMNI TASHKIL QILISH XUSUSIYATLARI}

\section{Umarov Komil Majitovich \\ Nasimov Ulug'bek Orif o'g'li \\ Samarqand Davlat Universiteti o'qituvchilari}

Annotation: Peculiarities dependent on developing tourism are illuminated in this article. Summaries about organizing effectively leasure time of pupils studying in schools and increasing the results of tourism are given. Recomendations about developing tourism are made.
Key words :

walking, regional

studies, the structure

of tourism.

Mustaqil Respublikamizda turizm xalqaro ahamiyatga ega bo'lgan ijtimoiy-madaniy, siyosiy, iqtisodiy va tarbiyaviy jarayon sifatida mavjuddir. Mamlakatning geografik sharoiti va ijtimoiy-madaniy, iqtisodiy tuzilmalari asosida turizm ikki yo'nalish (ichki va xalqaro turizm) sohasiga ajratilgan. Ular, asosan, sayr (ekskursiya) sayohatlar (piyoda va turli ulovlarda yurish) shaklida olib boriladi. O'zbekiston respublikasi Prezidentining 2017-yil 17-avgustdagi "2018-2019-yillarda turizm sohasini rivojlantirish bo'yicha chora-tadbirlar to'g'risida"gi qarori va ta'lim-tarbiyaga doir rasmiy hujjatlarda tarbiya va o'quv muassasalarida turizm sayohatlarini qo'llash qayd etilgan. $\mathrm{Bu}$ yo'lda kichik yoshdagi bolalarning sog'lom o'sishlari, gavda harakatlari va tuzilish jarayonlari benuqson bo'lishida jismoniy mashqlar, turli xil o'yinlar kabi sayr-sayohatlar ham o'zining maqsad, vazifa va mohiyatlariga ega. $\mathrm{Bu}$ jarayonlarni nazariy va amaliy jihatdan o'rganishda bo'lajak mutaxassislar sayr-sayohatlarni qunt bilan o'rganib, o'zlashtirib olishlariga to'g'ri keladi.

Ma'lumki, yuqorida qayd etilgan oliy va o'rta maxsus o'quv yurtlarining "Jismoniy tarbiya» dasturlarida «Sayohat»ga doir bo'limlar ajratilgan. Shu bilan birgalikda, «Alpomish» va «Barchinoy» maxsus testlarining mezon (normativ) talablarida ham talabalar uchun turizm turi kiritilgan. Shu asosda, o'quv yili davomida 1-2 marotaba bir kunlik sayohatlar tashkil etilmoqda. Sayr-sayohatlarni tashkil qilishda egallangan nazariy bilimlar va amaliy ko'nikmalarga tayanishadi. Shu asosda, tajribalar hosil qilib, ya'ni sayrsayohatlarni o'tkazish kunikmalariga ega bo'lishadilar [1].

Ta'lim muassasalarida tashkil etiladigan sayr-sayohatlar yoshga qarab quyidagi turlarga ajratiladi:

- ta'lim muassasasi hovlisi va uning tashqarisida kichik sayr-tomoshalar uyushtirish (har kuni 15-20 daqiqagacha olib borish);

- ob-havo qulay paytlarida aholi istiqomat qilish va e'tiborga loyiq manzillarga (istirohat bog'lari, kino-teatr, sport inshootlari va h.k.) larga har 2-3 haftada bir marta piyoda 1-2 km sayr-sayohat uyushtirish;

- Mustaqillik kuni, Navro'z bayrami va boshqa ulug' sanalarga bag'ishlab tabiatning go'zal manzarali, go'shalariga piyoda sayr-sayohat uyushtirish (ajratilgan vaqtda borish va qaytish);

- o'quv yili davomidagi kuzgi, qishki, bahorgi va yozgi ta'til paytlari bir kunlik (dam olish kuni) va darsdan keyingi paytlarda sayr-sayohatlar tashkil qilinishni an'anaga aylantirish;

- «Alpomish» va «Barchinoy» maxsus testlarining mezon (normativ) talablari asosida o'quv yilida 1-2 marotaba 4-5 km masofalik yo'nalishda bo'lgan joylarga piyoda yurish sayr-sayohatlarni uyushtirish;

- ta'lim-tarbiya tizimida saboq oluvchi o'quvchi yoshlar va talabalar turizm bo'yicha referatlar tayyorlash, ilmiy-nazariy anjumanlarda ma'ruza o'qish, talabalar ilmiy jamiyatlari (uyushmalari) faoliyatida va sport klub ishlarida faol qatnashish bilan ilmiynazariy bilimlarini chuqurlashtirish va amaliy malakalarini kengaytirish; 
- jismoniy tarbiya o'qituvchisi va sinif rahbari ishtirokida darsdan keyin va dam olish kunlari 1-2 km masofalarga sayr-sayohatlar tashkil qilish;

- jismoniy tarbiya o'qituvchisi va sinf rahbari sayohatlar vaqtida bolalarning shaxsiy xususiyatlari, ruhiy holatlari, jismoniy tayyorgarliklarini yaxshi bilish, ularning ko'p qirrali savollariga aniq va to'g'ri javob berish;

- ta'lim-tarbiya sohasida o'quvchi-yoshlarni jismoniy tayyorgarligi va ongini rivojlantirishga qaratilgan sayr-sayohatlarlarni imkon qadar ko'paytirish;

- mutaxasislar yosh avlodga bilim berish, mehnat va mudofaaga layoqatli qilib tarbiyalashdagi ehtiyojiy xususiyatlarini ilmiy-nazariy va pedagogik jihatdan o'rganish, mulohazalar yuritish, tahlil qilish usullarini egallashga, pedagogik mahorat yo'llari sirlarini bilishga astoydil qiziqishlari zarurdir [1,2].

Ta'lim muassasalarida bolalarning yoshi va sog'lomlik holatlariga qarab sayrsayohatlarni o'tkazish muddati, vaqti, masofalari sharoitlarga qarab tanlanishi hamda belgilanishi lozim. Bunday paytlarda bolalarning ruhiy holati, qiziqishi yoki yoqtirmasligi (bosh tortish) kabi fazilatlariga jiddiy e'tibor berish talab etiladi.

\section{Ta'lim muassaasalarida turizmni tashkil qilish tizimi}

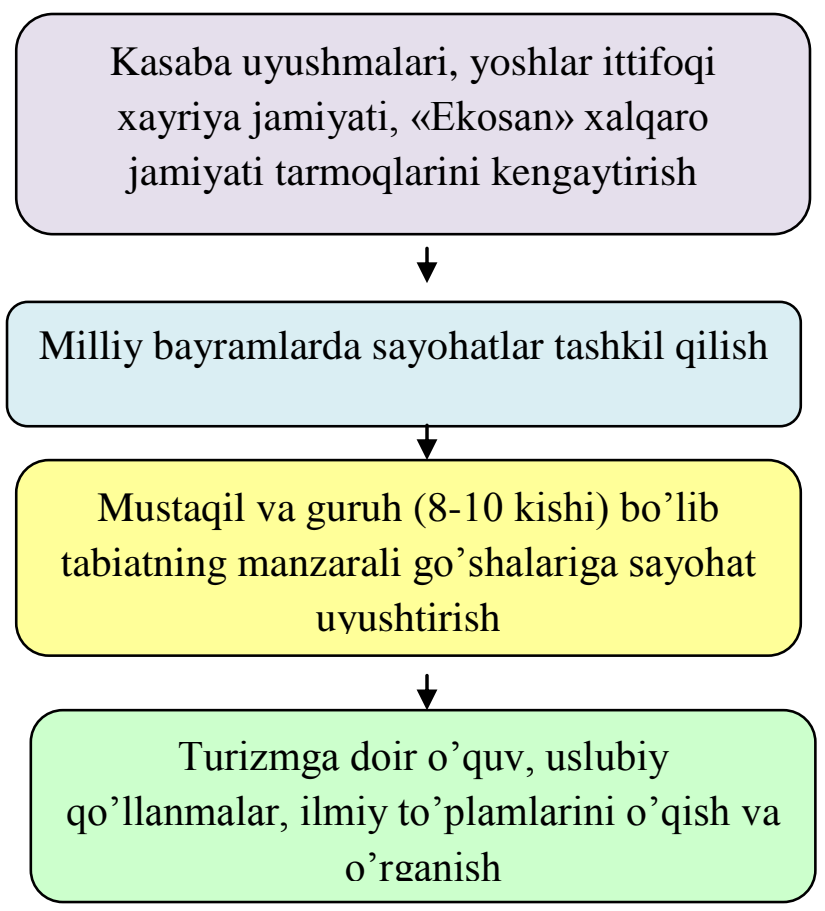

Ta'lim muassasalarida o'quvchi yoshlar bilan utkaziladigan sayr-sayohatlarni uyushtirishda yoshlar ittifoqi yetakchilari bu vazifalarni to'la amalga oshirishda jonbozlik qilishlari zarur. Soha mutaxassislari va turizm havaskorlari bu tizimni chuqur o'rganishi talab etiladi.

Keyingi vaqtlarda geografiya, botanika, zoologiya, tarix o'qituvchilari hamkorligida ko'pgina maktablarda o'lkashunoslik xonalari tashkil qilinmoqda. Ularda o'lkashunoslikning muhim tarmog'i bo'lgan turli gerbariylar, tabiatda uchraydigan xilma-xil toshlar va boshqa jihozlar mavjud. Bir so'z bilan aytganda, o'quvchi-yoshlar sayohat vaqtida uchratgan qiziqarli buyumlarni olib kelib, o'z muzeylariga yig'ishadi, ularni avaylab saqlashadi. Bunda jismoniy tarbiya o'qituvchilari va sinf rahbarlarining hissasi katta. Lekin shuni ham aytish joiz, ayrim sayohatchilar kolleksiya yoki gerbariy to'plashga unchalik e'tibor berishmaydi, buni o'z vazifalari deb qaramaydilar. Natijada maktablarda turizm bo'yicha maxsus muzey yoki burchaklar juda kamchilikni tashkil qiladi. 
Shularni nazarda tutib, har bir ta'lim muassasasida o'lkashunoslik va turistik to'garaklarni jonlantirish, ish faoliyatini kuchaytirish, tegishli jihoz va imkoniyatlar bilan ta'minlash, maxsus muzeylar (burchak) tashkil qilish maqsadga muvofiqdir [3].

Xulosa o'rnida shuni takidlash joizki, turizm mashg'ulotlari o'quvchi-yoshlarni jismoniy barkamol qilish bilan birga, mamlakatimiz hududi, tabiati, iqlim sharoitlari, hayvonot va o'simlik dunyosi hayoti, tarixiy obidalari hamda milliy meroslarini o'rganishga katta yordam beradi.

\section{Adabiyotlar:}

1. R.A. Qosimova Turizm va uni o'qitish metodikasi. O'quv qo'llanma. T., "Aloqachi" nashriyoti. 2008 yil $40-44$ bet

2. X.Tulenova, T.Xoldorov “Turizm”. O'quv qo'llanma.. -Тошкент «Iqtisod-moliya» 2012 yil 29-31 bet

3. B.Egamov, G.Abdusattorova Oromgohlarda sayyohlik va o'lkashunoslik faoliyatini tashkil etish.T.2009 yil 31-33 bet

4.

\section{ЎЗБЕКИСТОНДА ТУРИЗМНИ РИВОЖЛАНТИРИШ ИСТИҚБОЛЛАРИ}

\section{Умаров Тохир Облақулович Ипак йўли" туризм халқаро университети стажёр-тадқиқотчиси E-mail: tohir.umarov.2018@mail.ru}

Annotation: The article highlights the issues of tourism in Uzbekistan, the prospects for the development of tourism business, and the possibility of opening new tourism destinations
Key words : tourism, investment, visa, grant, credit, infrastructure, currency

Кириш. Мамлакатда туризмни миллий иқтисодиётни диверсификация қилиш, худудларни жадал ривожлантириш, янги иш ўринларини яратиш, ахолининг даромадлари ва турмуш даражасини ошириш, мамлакатнинг инвестициявий жозибадорлигини оширишни таъминловчи стратегик тармоқлардан бири сифатида ривожлантириш бўйича комплекс чора-тадбирлар босқичма-босқич амалга оширилмоқда.

Бугунги кунда туризм кўплаб ривожланаётган мамлакатларнинг асосий даромад манбаи бўлиб хизмат қилмоқда. Туризм хизматларини экспорт қилиш иқтисодиётда қўшимча талаб яратиб, ахолини иш билан таъминлайди ва хорижий валюта тушумини оширади. Шу орқали туризм сохаси иқтисодий ривожланишнинг харакатлантирувчи кучи сифатида мухим рол ўйнайди.

Худудларнинг туристик имкониятларни аниқлаш ва туризмнинг ўзига хос турларини ташкил этишнинг назарий ва амалий асосларини ишлаб чиқиш хамда қўллаш мавзусининг долзарблигини ифодалайди. Ўзбекистонда туризмни ривожлантириш бўйича кўплаб чора-тадбирлар ўтказилиб, амалиётда ижобий тасдиғини топмоқда.

Асосий қисм. Жахон сайёхлик ташкилотининг маълумотларига кўра, туризм сектори экспорти жахон саноатида кимё ва ёқилғи ишлаб чиқаришда автомобилсозлик саноатини ортда қолдириб 3-ўринни эгаллайди. Аксарият ривожланган мамлакатлар учун туризм экспортнинг этакчи туридир. 2017-йилда туризм сохаси экспортининг умумий хажми 1,6 трлн. АҚШ доллари, яъни кунига 4,4 миллиард АҚШ доллари (1 туристга 1200 АҚШ доллари), бу халқаро товарлар ва хизматлар экспортининг (22,9 триллион АҚШ доллари) 7 фоизини ва халқаро 
экспортнинг 29 фоизини ташкил этади. Хизматлар (5,4 трлн. АҚШ доллари). 2010 2017-йилларда дунё бўйича туристик хизматлар экспорти ўсишининг ўртача йиллик суръати 4-7 фоизни ташкил этди.

Туризм сохаси жахонда бўладиган жами экспортнинг 10 фоизини беради, хизматлар савдосининг эса 35 фоизи туризмга тўғри келади. Буюк ипак йўлида жойлашган, асрлар давомида қадимий шахарлари билан машхур, тарихий ва маданий ўтмишга эга Ўзбекистон Республикаси туризм тармоғини ривожлантириш учун реал имкониятларга эга. Ўзбекистон ўзининг тарихий ёдгорликлари, бой маданий ва тарихий анъаналарини сақлаб қолган, гўзал ва бетакрор табиат манзараларига эга давлат хисобланади. Юртимизда 7 минг 300 дан ортиқ маданий мерос объектлари мавжуд ва уларнинг аксарияти ЮНЕСКО рўйхатига киритилган. Буюк ипак йўлида жойлашган юртимизда тарихий ва маданий анъаналар асраб-авайлаб авлоддан-авлодга ўтиб келмоқда.Шу боис ; Ўзбекистон Республикаси Президенти Ш.М.Мирзиёвнинг 2019 йил 5 январдаги “Ўзбекистон Республикасида туризмни ривожлантиришни жадаллаштиришга доир қўшимча чора-тадбирлар тўғрисида"ги ПФ-5611-сонли қарорига мувофиқ мамлакатда бир қатор ислохотлар амалга оширилмоқда, жумладан айрим давлатлар билан виза режимини енгиллаштириш, хаво ва йўл транспортлари қатновини ошириш, айрим қўшни давлатлар билан кириш ва чиқиш тизимларини соддалаштириш, хорижий сайёхларнинг Ўзбекистонда қолиш муддатларини узайтириш, туризм сохасига киритилаётган хорижий ва махаллий инвестициялар учун солиқ ва бож тўловларида имтиёзлар бериш, туризм инфратузилмасини замон талабларига мос равишда ривожлантириш, банк кредитлари ва давлат грантларидан унумли фойдаланиш каби масалалар ўз ечимини топмоқда.

Бундан ташқари, Президентимизнинг тегишли қарори билан вилоятларда туризмни бошқариш тизимини янада такомиллаштириш мақсадида Тошкент, Самарқанд, Бухоро ва Хоразм вилоятлари, шунингдек, Хива ва Шахрисабз шахарлари туризм масалалари билан шуғулланувчи хоким ўринбосарлари лавозимлари жорий этилди. Ўтган давр мобайнида давлатимиз рахбарининг топшириғига биноан Хоразм, Бухоро, Самарқанд, Сурхондарё, Қашқадарё, Жиззах ва Фарғона вилоятларида туризм инфратузилмасини яхшилаш, янги сайёхлик йўналишларини ташкил этиш ва худудларнинг сайёхлик салохиятини кенг тарғиб этишга қаратилган дастурлар қабул қилинди. 1

Хулоса ва таклифлар. Хулоса қилиб шуни айтиш мумкинки, яқин келажакда Ўзбекистон хам бошқа туризми ривожланган мамлакатлар қаторига қўшилиб ўз брендини яратади. Чунки мамлакатимизда хорижий ва махаллий сайёхлар учун етарлича туризм масканлари, табиий ресурслар, махаллий ахолининг маънавий бойликлари (қадимий урф-одатлари, анъаналари в.б), табиий иқлим шароитининг (тўрт мавсумнинг ўз вақтида келиши) мослиги, қўшни давлатлар билан дўстона алоқаларнинг мустахкам эканлиги, кўп миллатли Ўзбекистонда тинчлик хукм сураётганлиги бунинг яққол мисолидир. Бундан ташқари сифатли кадрлар ва малакали мутахассисларга бўлган эхтиёж ортаётганлигини инобатга олиб хукуматимиз қолаверса шахсан Президентимиз ташаббуси билан олийгохлар барпо этилмоқда. Бу хам келажакда туризмнинг истиқболли сохалардан бири эканлигидан дарак беради.

Таклиф ўрнида шуларни айтиб ўтишимиз мумкин:

- $\quad$ Ўзбекистон хақидаги тўлиқ маълумотларни турли тилларда бутун жахон оммасига тақдим этиш.

- $\quad$ Янги туристик дестинацияларни ташкиллаштириш. 
- Зиёрат мақсадида келаётган сайёхлар учун объектларда (тахоратхона, автотураргох в.б) қулай шароитларни яратиш.

- Рақамли туризмни ривожлантириш ва бошқалар.

\section{Фойдаланилган адабиётлар:}

1.Ўзбекистон Республикаси Президенти Ш.М.Мирзиёвнинг 2019 йил 5 январдаги "Ўзбекистон Республикасида туризмни ривожлантиришни жадаллаштиришга доир қушимча чора-тадбирлар тўғрисида"ги ПФ-5611-сонли қарори. https:// lex.uz/docs/ 4143188

2.Ўзбекистонда туризмни ривожлантириш асослари. О.Р.Райимбердиев Молодой ученый. 2017. — № 7 (141).

3. Замонавий шароитда туризмни ривожлантириш истиқболлари. Россия давлат педагогика университети А.С.Лесков (Журнал-2017)

4.Ўзбекистонда туризмни ривожлантириш истиқболлари. $\quad$ https:// moluch.ru /archive/ $\underline{117 / 32279 /}$

\section{O'ZBEKISTONNING TURIZM SALOHIYATINI OSHIRISHGA DOIR}

\section{Muqumov Toshqobil \\ SamDChTI o'qituvchisi \\ E-mail : mukumov@samdchti.uz}

Annotation: The article reviews global, regional and national tourism development in some countries. The trends and prospects for the development of modern tourism markets including urban travel, halal tourism and other tourism destinations are covered. Opportunities and perspectives of tourism development in Uzbekistan were also studied based on the experience of foreign countries.
Key words :

tourism, outbound tourism, domestic tourism, visa regime simplification, urban travel, halal tourism, pilgrim tourism, infrastructure.

Bugungi kunga kelib hech kimga sir emaski turizm eng tez rivojlanayotgan iqtisodiy jabhalardan biri hisoblanadi. Mutaxasislarning fikriga ko'ra, hozirgi kunda u dunyo bo'yicha avtomobilsozlik va neftni qayta ishlash sohasidan keyin uchinchi o'rinni egallab turibdi va turizm ushbu asrning eng daromadli sohasiga aylanishi pragnoz qilinmoqda. Turizm sohasi rivojlanishi o'zi bilan birgalikda transport, oziq-ovqat, mehmonxona, savdo-sotiq, hunarmandchilik, qurilish va boshqa sohalarni ham rivojlanishiga olib keladi. Bundan tashqari, mamlakat tashqi qiyofasini zamonaviylashtirish, mehmonxona va restoran industriyasini rivojlantirish hamda transport-kommunikatsiya tizimlari kabi tarmoqlar o'rtasidagi aloqalarni shakillantirishga xizmat qiladi. Turizmning global ravishda rivojlanishi turli davlatlarni bir-biriga yaqinlashtirib, ularning o'zaro munosabatlarini faollashtirishda eng ishonchli va eng mustahkam tizimdir. Turizmning rivojlanishi deyarli barcha sohalarga ijobiy ta'sir ko'rsatib mamlakat iqtisodiyotining dinamik tarzda o'sishiga olib keladi.

Ushbu sohaning har bir davlat ijtimoiy-iqtisodiy hayotidagi ta'sirini mamlakat hayotidagi kichik biznes va tadbirkorlikni rivojlantirish, milliy qadryatlarni saqlash va ularni jahonga namoyon qilish, qolaversa, bugungi kun mamlakatimizdagi dolzarb masalalardan biri bo'lgan ish bilan ta'minlash, shuningdek valyuta tushumida ko'rishimiz mumkin. Shu boisdan hozirgi kunda yurtimizda ham turizmni rivojlantirish, uning iqtisodiyotdagi rolini oshirish uchun katta e'tibor qaratilmoqda va bunga doir qator islohotlar olib borilmoqda. Bu islohotlar mamlakatimiz turizm salohiyatini rivojlantirishda eng muhim omillar bo'lib xizmat ko'rsatmoqda. Buning isboti sifatida davlatimiz rahbari Sh.M. Mirziyoyevning 2017-yil 7-fevraldagi Farmoni bilan tasdiqlangan, 2017-2021 yillarda O'zbekiston Respublikasini rivojlantirishning beshta ustuvor yo'nalishi bo'yicha 
Harakatlar strategiyasida turizm industriyasini jadal rivojlantirish, mamlakatimiz iqtisodiyotida uning roli va ahamiyuatini oshirish, xorijlik mehmonlar uchun xizmatlarni qaytadan shakllantirish va uning sifatini yanada yaxshi tomonga o'zgartirish, turizm infratuzilmasini kengaytirish belgilandi ${ }^{1}$. Qolaversa O'zbekiston Respublikasi Prezidenti Shavkat Mirziyoyev o'zining Oliy Majlisga murojaatnomasida " Hozirgi kunda milliy iqtisodiyotga yuqori daromad keltiradigan istiqbolli tarmoqlardan biri - bu turizmdir. O'zbekiston turizm sohasida ulkan salohiyatga ega bo'lgan davlat hisoblanadi. Yurtimizda 7 ming 300 dan ortiq madaniy meros obyektlari mavjud va ularning aksariyati YuNESKO ro'yxatiga kiritilgan", - deb takidlagani bu soha rivojining naqadar muhim ekanligini ko'rsatib turibdi².

Turizm iqtisodiyotning strategik tarmog'i sifatida mamlakat taraqqiyotini ta'minlashda muhim omil bo'lib xizmat qiladi. Sayyohlarga qulay sharoitlar yaratishga mo'ljallangan xalqaro me'yor va standartlarni mamlakatimizda tatbiq etish, turizm sohasi infratuzilmasini rivojlantirish, sayyoglarga qulay turizm muhitini yaratish, transport logistikasini rivojlantirish, ichki va tashqi yo'nalishlarni kengaytirish, transport xizmatlari sifatini oshirish, O'zbekiston Respublikasi turizm mahsulotini xalqaro va ichki turizm bozorlarida targ'ib qilish, mamlakatning sayohat va dam olish uchun xavfsiz sifatidagi imidjini mustahkamlash hamda turizm tarmog'i uchun yetuk kadrlar tayyorlash kabilar yurtimizda turizmni rivojlantirishning muhim elementlari hisoblanadi. O'zbekiston uchun ham jadal rivojlanib borayotgan turizm sohasiga alohida e'tibor qaratish keng imkoniyatlarini yaratadi. Yurtimizda bugungi kunda hukumat tomonidan muhim e'tibor qaratilayotgan ishsizlik muammosini bartaraf etishda ham turizm muhim rol o'ynaydi. Keyingi o'n yillikda har to'rtta yangi ish joyidan bittasi turizm sektori tomonidan yaratilishini inobatga olsak, turizm O'zbekistonda qo'shimcha ish o'rinlarini yaratib ishsizlik darajasini pasaytirishga katta hissa qo'shishi mumkin. O'zbekistonda milliy iqtisodiyotni ko'p tarmoqli qilish, mamlakatda investitsiylarni kirib kelishini yanada oshirishni ta'minlovchi strategik tarmoqlardan biri bo'lgan turizmni rivojlantirish bo'yicha keng ko'lamli chora-tadbirlar amalga oshirilmoqda. $\mathrm{Bu} \mathrm{o}^{\prime} \mathrm{z}$ navbatida axolining yuqori daromad manbayi hamdir. Ayniqsa qisqa muddatli sayohatlar, shahar turizmi, gastronomik turizm va ziyorat turizmini rivojlantirish o'zbek turizmining asosi deyishimiz mumkin ${ }^{3}$.

Jahon turizmi uchun yurtimizning geografik jihatdan ancha qulay joylashganligi muhimdir. Buyuk ipak yo'li chorrahasi hisoblangan markaziy Osiyo bugungi kunda turizm rivojlangan Yevropa, Yaqin sharq, Janubi-sharqiy Osiyo mintaqlarining markazidir. Bu omil turistlar uchun qisqa mudatli tranzit sayohatlarini amalga oshirishlari uchun muhim hisoblanadi. Yurtimiz transportining ichki va tashqi turlarini hisobga olgan holda sayyohlik oqimini ko'paytirish va diversifikatsiya qilish uchun yagona, xavfsiz va innovatsion transport logistikasini rivojlantirish lozim.

O'zbekiston tarixiy shaharlari bilan dunyo turistlari nigohini o'ziga qaratayotgan davlat hisoblanib, tarixiy madaniy obidalarga boydir. Jumladan: 7200 dan ortiq madaniy yodgorliklardan 200 ga yaqini YUNESKO ro'yxatiga kiritilgan. $\mathrm{Bu}$ o'zbek turizmiga o'zgacha jozibadorlik beradi. Madaniy meros ob'ektlari, muzeylar, teatrlar, san'at galereyalari faoliyati samaradorligini sayyohlarni axborot-ma'lumot bilan ta'minlashning samarali tizimini yaratish, aqlli turizm texnologiyalarini joriy etish va videokuzatuv tizimini o'rnatish orqali oshirish lozim. Albatta o'z o'rnida zamonaviy shaharlarning bunyod etilishi ham xorijlik sayyohlarning qamrovini kengaytirishga yordam beradi ${ }^{4}$. 
Yurtimiz islom olamida o'z tarixi bilan yuqori mavqeyga egadir. Musulmon sayyohlarning Imom Buxoriy, At-Termiziy, Moturudiy ziyoratgohlariga tashrif buyurish uchun istaklari yuqori ekanligi hozirgi kunda islom davlatlaridan yurtimizga kelayotgan mehmonlar miqdori salmoqli ekangligi bilan xarakterlanadi. Shuningdek, musulmon turistik bozori yildan yilga kengayib, talab ham ortib bormoqda. Yurtimizda katta turistik oqimni yo'lga qo'yish musulmon mamlakatlari turistlarini jalb qilish va halol turizmni rivojlantirish orqali amalga oshirish mumkin. Shuning uchun ziyorat turizmi infrastrukturasini shakllantirish, ziyoratgohlar haqida ma'lumotlar bazasini shakllantirish hamda ziyoratchilar uchun qulay sharoitlarni yaratish bugungi kun turizm sohasining dolzarb muammolaridan biri hisoblanadi.

\section{Adabiyotlar:}

1. O'zbekiston Respublikasi Prezidentining «O'zbekiston Respublikasi sayyohlik sohasini rivojlantirishni tezlashtirish chora-tadbirlari to'g'risida»gi farmoni. -T:2.12.2016y.

2. 2017 - 2021-yillarda 0‘zbekiston Respublikasini rivojlantirishning beshta ustuvor yo'nalishi bo'yicha Harakatlar strategiyasi. http://lex.uz/docs/-3107036

3. "O'zbekiston Respublikasini turizmni jadal rivojlantirishga oid qo'shimcha chora-tadbirlar to'g'risida" PF-5611, 05.01.2019y.

4. Ruziyev Sh.R. O’zbekistonda tarixiy-madaniy turizmni rivojlantirishning tashkiliy-iqtisodiy mexanizmini indikativ boshqarish metodikasi// Iqtisod va moliya ilmiy-amaliy jurnal. T.:2018 yil. №11(119). 30-bet.v

5. Safarov B. Turistik xizmatlar bozori istiqbolini aniqlashning innovatsion usullari// Iqtisodiyot va ta'lim jurnali. Toshkent sh., 2017 yil. №4. 47-bet.

\section{THE IMPORTANCE OF DEVELOPING THE MARKET OF MEDICAL SERVICES IN AN INNOVATIVE ECONOMY}

\section{Rakhimova Sadokat Makhmudovna Urgench state University Tourism and economy faculty, PhD student E-mail: Sadoqat8888@mail.ru}

Annotation: This article describes the current state of the medical services market in the context of innovative economy development In addition, measures to ensure the quality, efficiency and affordability of guaranteed health services have been studied and in-depth analysis of market systems of medical services in developed countries. The study investigated many theories of economists in foreign countries, especially in analyzing the market for medical services.
Key words :

medical service, social protection, economic effect, social effect, health insurance, health care, medical activity, medical culture, private medical system, compulsory health insurance.

INTRODUCTION. The role of the service sector in the development of the innovative economy is increasing significantly. Market economy envisages regulation of market mechanisms in society and creation of conditions for production and services through which economic relations are formed.

In recent years, technological diversification of the economy has had an impact on the development of the country's health care services market and put some demands on it.

According to the World Health Organization (WHO), health services are a special human need, and as a result of their consumption, health needs are met, and consumed health services are both socially and economically important. [1]

Health care is a profitable activity, but the service company needs to pay special attention to improving the health (social protection) and rehabilitation of the public property, as well as its social importance. 
Our country is pursuing reforms to further develop the health services market through the creation of a new and modern health care system, the regulation of the forms of ownership of healthcare providers and the use of state benefits.

The Strategy of Action for the Five Priorities of Development of Uzbekistan for 20172020, adopted by the President of the Republic of Uzbekistan, sets the following priorities for further improvement of health care:

First, to learn from the experience of developed countries in the provision of quality health services to the population, to implement measures to improve the quality of life through the introduction of high technologies in the provision of health services; Secondly, the gradual implementation of reforms to improve the availability of medical and social services and the widespread introduction of the compulsory health insurance system to provide services to the entire population; thirdly, the development of electronic health services centers in the country in the provision of health services, and as a result, the history of health care consumers is focused on creating a system to improve their statistical data. [2]

In addition, a number of decisions were made in this field. - State Program on strengthening reproductive health of the population of Uzbekistan in the years of protection of maternal and child health. In the framework of a number of adopted decisions, the development of the market of medical services in the Republic of Uzbekistan, development of investment programs, attraction and provision of permanent and effective access to medical services by the population [4] [5].

On April 1,2017, the issues of improving the quality of medical services in order to control the state of the prices for paid and free medical services in the country and ensure their provision by the state medical and preventive institutions on April 1, 2017 It is reflected in the Decree of the President of the Republic of Uzbekistan № PP-2863 "About measures for further development of the private sector in the health sector", adopted by the President Sh.M. Mirziyoyev [6].

RESULT AND DISCUSSION. The size, structure and level of development of the services sector are important in assessing the economic status of the country.

The major conference, "The Economics of Medical Care," organized by the American Economic Association in 1951, is an important historical event in the study of the role of medical services in the market economy of the world. The establishment of scientific and research centers, research on economic aspects, and a special focus on reducing the economic harm to the population in the health sector have been studied as a first priority [7].

The World Health Organization's first meeting was held in 1973, addressing health issues in countries around the world. The summit will evaluate the biggest health impact recovery, consolidation of human health, and the amount of financial resources spent by the country in the national economy and their revenues.

American economists play a major role in the development of the medical services market. Economist Kenneth Joseph Arrow in his article "Health Wellbeing and Economics" addresses the disadvantages and contradictions of the medical services market explains as follows;

- insufficient information about health care consumers, in particular insured persons, vaccinated for disease prevention,

- Diagnosis of the patient,

- In general, the level of access to health services (medical culture) is considered by the population to be the main disadvantage of the medical services market. This determines the scope and scope of the medical services market, and the increasing demand for services and demand causes expensive trends in the healthcare sector . In modern economics, researchers $\mathrm{L}$. Berry, V. Zaytaml and A. Parasuraman analyzed the basic concepts such as variability in the quality of health services, the concept of health care, and the effectiveness of health care. According to the economists, the development of the market for medical services in the country 
is a social phenomenon, and then it is deeply studied how to improve the health and economic relations of the population through the provision of medical services. Researchers have extensively analyzed a number of concepts in health care services such as "health", health care "medical care", and "medical activity", the social effect of health care, economic efficiency.

\section{References :}

1.Финансирование систем здравоохранения.Путь к всеобщему охвату населения медикосанитарной помощью.WHO Library Cataloguing-in-Publication Data.The world health report: health systems financing: the path to universal coverage.2010y

2. Decree of the President of the Republic of Uzbekistan dated February 7, 2017 № P-4947 "On the Strategy of Action for the Further Development of the Republic of Uzbekistan". Collection of Laws of the Republic of Uzbekistan, 2017, № 6, Article 70

3.Resolution of the Republic of Uzbekistan "On Sanitary Epidemiological Survival of the Population, Decision of the Republic of Uzbekistan-363 August 25, 2015

4. Decision on the prevention of iodine deficiency diseases, 3. Decision of the Republic of Uzbekistan- 97 03.05.2017

5. Resolution of the Government of the Republic of Uzbekistan No. PP-2221 "On the State Program for the Protection of Reproductive Health of the Population of Uzbekistan for 2014-2018"

6.On April 1, 2017 by the decree of the President of the Republic of Uzbekistan Sh.M. Mirziyoev "About measures for further development of the private sector in the sphere of healthcare" DP-2863

7. А. Р. Ильясова Основы экономики здравоохранения. Учебное пособие Казань, 2019.86 с.

\section{TURIZM TERMINI XUSUSIDA BA'ZI MULOHAZALAR}

\section{Eshboyeva Tursuntosh Soxatmamatovna \\ Samarqand davlat chet tillar instituti magistranti E-mail: tanyaeshboyeva@gmail.com}

Annotation: This article discusses the main tools that make up toutism and their types, the origin of the term tourism and decisions about tourism.Based on the above considerations, it can be said that the concepts of tourism and tourism are defferent from each other.In general, it is considered that tourism has a special educational value as an important tool inimproving the health of people, increasing their physical fitness.
Key words : Tourism, relax, healing ,travel, social tourism, tourist, reception of tourists, international tourism, national tourism, sending tourists.

XXI asr jahon iqtisodiyotida turizm sohasi juda katta ijobiy ta'sir qilmoqda. Buni ijtimoiy-iqtisodiy sohalarda ko'rish mumkin. O'zbek tilidagi zamonaviy terminologik tizimlarni o'rganish, soha terminlarini to'plash, saralash, tartibga solish va shu asosida lug'atlar tuzib nashr etish ishlari asosan o'tgan asrning 30- yillaridan boshlangan. Keyingi davrlarda bu sohadagi tadqiqotlar biroz susaygan bo'lsa-da, mustaqillik yilllarida yana rivojlanish pallasiga kirdi.

O‘zbek tiliga Davlat tili maqomining berilishi va respublikamiz ijtimoiy hayotidagi yangicha til siyosati umumtil amaliyoti bilan bir qatorda soha terminologik tizimlarida ham so'z-terminlar va iboralarni o'z o'rnida qo'llashga imkon yaratdi. Bunda ona tili materiallaridan keng foydalanishga jiddiy e'tiborni taqozo etganligi bois turistlar o'rtasidagi muomalaning qulay va tushunarli bo'lishi, turizm sohasida ish yuritishning yengillashtirish maqsadida soha uchun lug'atlar tayyorlanishi zarurati paydo bo'ldi.

Mamlakatimizda mustaqillik yillarida turizmni rivojlantirish uchun zaruriy tashkiliyhuquqiy mexanizmlar vujudga keltirildi, ya'ni tegishli me'yoriy hujjatlar qabul qilindi. O'zbekiston Respublikasi turizm sohasi tezkorlik bilan rivojlanayotgan davlatlar 10 taligi ro'yxatiga kiritildi. Turizm haqida gapiganda, bu so'zning asl kelib chiqish manbasi va izohi ahamiyatlidir. Turizm terminiga adabiyotlarda turlicha ta'riflar beriladi: "Ma'lum marshrut 
bo'yicha ham tomosha qilish va dam olish, ham sport, ham umumiy ma'lumotni oshirish maqsadida uyushtirilgan sayohat va shunday sayohatlar bilan shug'ullanish.

Turizm so`zi fransuzcha "tourisme ,tour "sayr qilish aylanish demakdir. Turizmning tobora rivojlanayotganini e'tiborga olib, turistik poyezdlar marshruti yanada ko'paytirildi.

O‘zbekiston Respublikasining “Turizm to'g'risida”gi Qonunida turizm tushunchasiga berilgan ta'rifni ishonchli deyish mumkin: " Jismoniy shaxslarning doimiy istiqomat joyidan sog'lomlashtirish, ma'rifiy, kasbiy-amaliy yoki boshqa maqsadlarda borilgan joyda (mamlakatda) haq to'lanadigan faoliyat bilan shug'ullanmagan holda uzog'i bilan bir yil muddatga jo'nab ketishi (sayohat qilishi)". Yuqoridagi fikrlardan kelib chiqib shuni aytish mumkinki, turizm va sayyohlik tushunchalari birbiridan farq qiladi. Ya'ni turistlar uchun boradigan manzili va vaqti aniq belgilansa, sayohlarda aniq bir vaqt va manzil inobatga olinmaydi, ya'ni sayohat vaqti aniq belgilanmaydi.Shu jihatdan bu terminlarni o'z o'rnida qo'llash maqsadga muvofiq bo'ladi.

Demak, turizm belgilangan reja asosidagi sayohat demakdir. Uning mazmunida dam olish, hordiq chiqarish, jismonan chiniqish, o'lkani o'rganish, tabiatni muhofaza qilish, tabiiy muvozanatni saqlash (ekologiya) kabi keng qamrovli ijtimoiy-tarbiyaviy hamda madaniy jarayonlar mujassamlashgan.

Ularni amalga oshirishda tashkiliy va boshqaruv faoliyatlar muhim ahamiyat kasb etadi. Ta'kidlash lozimki, turizmning bu yo'nalishidagi vositalaridan dunyodagi ko'p mamlakatlarda maqsadli foydalanib kelinmoqda. Shu sababdan turizmning o'ziga xos tarixiy rivojlanishi mamlakatlaming ijtimoiy-iqtisodiy, madaniy va siyosiy faoliyatlari bilan bevosita bog'liq bo'ladi.

Turizm shaklan sayr (ekskursiya), sarguzashtlar (путешествие, экспедиция) va piyoda yurish (пешеход) kabi turlarni o'z ichiga olib, mazmunan esa insonlarning bilim doirasini kengaytirish, aql-idroki (tafakkur) rivojlantirish hamda jismoniy barkamollikni tarbiyalash kabi eng muhim vazifalarni hal qilishni o'zida qamrab oladi.

Mamlakatimizda turizm sohasini yanada rivojlantirish maqsadida O’zbekiston Respublikasi Prezidenti Sh.M.Mirziyoyevning 2016-yil 2-dekabrdagi “O'zbekiston Respublikasining turizm sohasini jadal rivojlantirishni ta'minlash chora-tadbirlari to'g'risida"gi qabul qilingan Farmoni tarixiy ahamiyatga ega bo'ldi.

Bu Farmonning mantiqiy davomi sifatida 2017-2021-yillarga mo'ljallangan "Harakatlar strategiyasi"da ham turizmni rivojlantirish haqida ma'lumotlarga duch kelamiz: "0'rta muddatli istiqbolda O'zbekiston Respublikasida turizm sohasini rivojlantirish konsepsiyasini, shuningdek, 2017-2021-yillarda Konsepsiyani amalga oshirishga doir aniq chora-tadbirlar dasturini ishlab chiqish".

Ko'rinadiki, turizm sohasini rivojlantirish davlat ahamiyatiga molik masalalardan biridir. Ta 'kidlab o`tish joizki, sayr-sayohatlar (ekskursiya) dunyo miqyosdagi eng ommaviy-madaniy tadbirlardan biridir. Tarixiy-madaniy obidalarni tomosha qilish, ularning tarixi bilan tanishish, zamonaviy qurilishlar, hashamatli uylar, chiroyli bog'-rog'lar, millatlarning urf-odatlarini o'rganish kabi sohalar turistlarning diqqat-e'tiboridan keng joy oladi.

Bugungi kunda O'zbekiston katta turistik resurslar salohiyatiga ega bo'lib, mamlakat hududida 7000 dan ortiq tarixiy-arxitektura yodgorliklari va go'zal tabiiy-iqlimiy resurslari mavjud. Ayniqsa, Samarqand, Buxoro, Xiva kabi tarixiy shaharlar. Toshkent, Navoiy, Guliston kabi zamonaviy shaharlarning ko'rki va yangi jamoli faqat mamlakatimiz aholisinigina emas, balki xorijiy mamlakatlarning ham diqqatini o'ziga jalb etadi. Umuman olganda, insonlarning sihat-salomatligini yaxshilash, ularning jismoniy barkamolligini oshirishda muhim vosita sifatida turizm o'ziga xos tarbiyaviy ahamiyatga egadir. Shu sababdan barcha aholi turizmning u yoki bu turi bilan shug'ullanishlari maqsadga muvofiqdir. 


\section{Adabiyotlar :}

1. 0'zbekiston Respublikasi Konstitutsiyasi. - T.: 0'zbekiston, 2003. 36b.

2. 0'zbekiston Respublikasining «Turizm to'g'risidagi» qonuni.// 0 'zbekistonning yangi qonunlari. -T.: Adolat, 2000. 131-140-b.

3. Karimov I. A. Tarihiy xotirasiz kelajak yo`q. «Sharq», 1998, 8-9 - betlar.

4. Usmon O., Doniyorov R. Ruscha-internatsional so'zlar izohli lug'ati. T., 1965.B-465.

5. 0 'zbek tilining izohli lug'ati. T., 2008. 4-tom, B-195.

6. M.T. Aliyeva, Mirzayev M. va boshqalar. Turizm huquqi. 0'quv qo'llanma. -T: Talqin, 2003. 245-b.

\section{TURIZM INFRATUZILMASI VA UNING YURTIMIZDA RIVOJLANISH ISTIQBOLLARI}

\section{Xayrullayeva Aziza Islamova Ozoda \\ Samarqand davlat chet tillar instituti talabalari E-mail : islamova@samdchti.uz}

Annotation: The main purpose of this article is to Key words : tourism infrastructure, inform students about the internal and external aspects of types of tourism, agrotourism, today's tourism industry autotourism, ecotourism.

Butun dunyo miqyosida turizm industriyasi eng ko'p daromad keltiruvchi sohalardan biri hisoblanib kelmoqda. Aynan mana shuning uchun ham ko'pgina davlatlar mazkur sohaning rivojlanishiga katta e'tibor qaratishmoqda. Shu jumladan O'zekiston respublikasi ham bu borada ir qancha ko'lamdor ishlarni amalga oshirib kelmoqda. Bu soha rivojida esa kadrlar tayyorlash ham yetakchi masalalardan biri bo'lib kelmoqda. O’zbekiston Respublikasi Prizedenti Shavkat Mirziyoyev ta'kidlaganlaridek: "Agar biz turizm hisobiga ish o'rinlari ochamiz desak, turistga shart qo'yish emas, balki sharoit yaratishimiz zarur" Turizm - bu zamonaviy, doimiy ravishda rivojlanib kelayotgan, yuqori daromadli xalqaro industriyadir. Turizm - fransuzcha "tour" so'zidan olingan bo'lib, "sayr, sayohat" degan man'oni bildiradi. Turizm industriyasi esa turizm va uning rivoji uchun tashkil qiladigan turistik markazlar, qolaversa bevosita turistlarga xizmat qiladigan transport infratuzilmasi, mehmonxonalar, motellar va sayyohlar uchun tashkil qilingan maxsus yotoqxonalar, umumiyovqatlanish maskanlari, muzeylar, istirohat va hayvonat bog'lari kabi sayyohlarni o'ziga jalb qila oladigan, hamda ularga malakali xizmat ko'rsatuvchi sohalarning umumiy majmuasidir. Turizm infratuzilmasi 4 asosiy omillardan tashkil topadi. Bular - transport, mehmonxona, animatsiya faoliyatlari (hordiq chiqaruvchi va dam oldiruvchi), turistik tashkilotlar.Turizmni turistik tashkilotlar orqali turistik marshrutlar bo'yicha uyushtiriishi aniq bir maqsadga qaralganligidadir. Aynan shuning uchun turizm juda ko'p turlariga va shakllariga bo'linadi:

1) ko'lamiga ko'ra:

a) ichki turizm - fuqarolarning o'z mamlakati bo'ylab sayohat uyushtirishi

b) tashqi turizm - fuqarolarning boshqa bir mamlakatlarga sayohati, yoki xalqaro miqyosdagi turizm kompleks ravishda dunyo bo'ylab bir nechta mamlakatlarga sayohat uyushtirishi.

2) maqsadiga ko'ra:

a) havaskorlik turizmi - fuqarolarning shunchaki qiziqish yohud ma'naviy hordiq chiqarish,dam olish maqsadidagi sayohat uyushtirishi.

b) ilmiy yoki bilim olish turizmi - fuqarolarning biror joyni o'rganish maqsadidagi uyushgan yoki uyushmagan holatdagi sayohatlar uyushtirishi. 
d) davolanish va sog'lomlashtirish turizmi - fuqarolarning mamlakat ichida yoki xalqaro miqyosda davolanish yoki sog'lom bo'lish maqsadida togli hududlarga, dengiz boylariga va boshqa joylrga sayohat uyushtirishi.

3. Sohalar bo'yicha:

a) agroturizm - mutaxasislar yoki fuqarolarning qishloq xo'jaligini o'rganish maqsadida sayohatlar uyushtirishi.

b) avtoturizm - fuqarolarning avtomobillar yordamida dunyoni aylanib chiqish maqsadida sayohatlar uyushtirishi

c) veloturizm - fuqarolarning velosipedlar yordamida bebosita tabiat qiyinchiliklariga bardosh berib, sayohat davomida barcha hodisalarni kuzatish maqsadida sayohatlar uyushtirishi

d) ekoturizm - mutaxassislar yoki fuqarolarning ekologik vaziyatlarni organish maqsadida sayohatlar uyushtirishi

f) sport turizmi - fuqarolarning turli sport musobaqalariga muxlislik qilish maqsadida mamlakat yoki dunyo miqyosida sayohat uyushtirishi

j) suv turizmi - fuqarolarning bevosita suv havzalarida bo'lish maqsadida sayohatlar uyushtirishi.

Turizm infratuzilmasi tushunchasi - turistlarning turistlik zaxiralaridan bemalol foydalanishini ta`minlovchi binolar tizimi, muhandislik va kommunikatsiya tarmoqlari, shu jumladan yo'llar, turizmning turli xizmat ko`rsatish korxonalari va ularni kerakli darajada ishlatish va ta`minlash tushuniladi. Bu avtomobil va temir yo'llar, yo'l harakatini, havo yo'llarini, dengiz va daryo yo'lari harakatini tartibga soluvchi, issiqlik, elektr va telefon aloqalari bilan ta`min lash va boshqa kommunikatsiya tizimlaridir. Ma'lumki, turizm sohasida turistlik resurslari, yani tabiiy-iqlim, tarixiymadaniy, ma`rifiy, ijtimoiy-maishiy turizm ob`ektlari bo'lgan hududlarda kerakli infratuzilmani yaratish muhim masalalardan biri hisoblanadi. Yo`l qurilishi sohasini olib ko`raylik. Albatta sayyohlar oddiy yo`lovchilar emas. Yo`llarning ravonligiga qarab ham sayyohlar oqimining oshishi yoki kamayishi mumkin. Yo'llar, bozorlar mamlakatning iqtisodiy va madaniy ahvoli qay darajada rivojlanganidan dalolat beradi. Turist - avvalo dam oluvchi bo`lib, unga ko`rsatiladigan xizmatlar iste`molchisi ekanligini unutmasligimiz lozim. Bular nafaqat avtomobil yo`llari, shuningdek, temir yo`llarga ham taalluqlidir. Vokzal va poyezd relslaridan tortib, uning ichidagi kommunikatsiya va muhandislik tarmoqlarining barchasi - turizm infratuzilmasining tarkibiy bir qismi, xolos. Nafaqat avtomobil yoki temir yo`llar, hatto turistlar uchun maxsus ajratilgan yo'llar ham talab darajasida bo`lmog'i kerak. Mehmonxona va shunga tenglashtirilgan joylardagi kommunikatsiya va muhandislik tarmoqlarida ham muammolar bo'lmasligi turizm sohasining yangi pog'onalarga ko`tarilishida o'ziga xos o`rinni egallaydi. Zero, yurtimiz ko`hna tarix va madaniyatga ega.

\section{Adabiyotlar:}

1. "Xalqaro bozorda milliy turizm" O’zbekiston iqtisodiy axborotnomasi, 2010. № 1-2.

2. AliyevaM.T. Развития индустрии туризма. //“Международные Плехановский чтения", 19 апреля РЭА.

3. им. Г. В. Плеханова, 2006.

4. www.world-tourism.org

5. www.treval-library.com

6. www.interunion.ru<http://www.interunion.ru $>$ 


\section{MILLAT URF ODATLARI - MILLAT G'URURI}

\section{Saidova Shaxnozabonu Shaxobiddin qizi Samarqand viloyat 54-maktab iqtidorli o'quvchisi IImiy rahbar : o'qituvchi Xudoyqulova Iroda E-mail : shahnozasaidova87@gmail.com}

Annotation: This article discusses contemplate about Uzbek national value and how to save them, transmission to the next generation and it is also given some ideas of Uzbek national traditions history.
Key words : national value, Uzbek nation, history, Uzbek national traditions, generation

Hammamizga ma'lumki, har bir xalqning o'ziga xos urf-odatlari va qadriyatlari mavjuddir. Milliy an'analar - millat hayotining xususiyatlari, qadriyatlari va xislatlarining avloddan avlodga o'tishi hamda o'tmishdan kelajak-ka meros bo'lib qolishini anglatuvchi tushunchadir. Ming yillik tarixga ega bo'lgan o'zbek xalqi asrlar davomida xilma-xil urf-odatlar va an'analarni yaratdi. Yer yuzidagi har bir millat o'ziga xos an'analari va qadriyatlari bilan bilan ajralib turadi. Mamlakatimiz mustaqillikka erishgandan so'ng milliy an'analarimizga e'tibor kuchaydi. Bugungi kunda avloddan avlodga o'tib kelayotgan bebaho qadriyatlar Navro'z, Xotira va qadrlash kuni, muborak Ramazon Hayiti kabi bayramlar bizning yurtimizda keng miqyosda nishonlanib kelinmoqda.
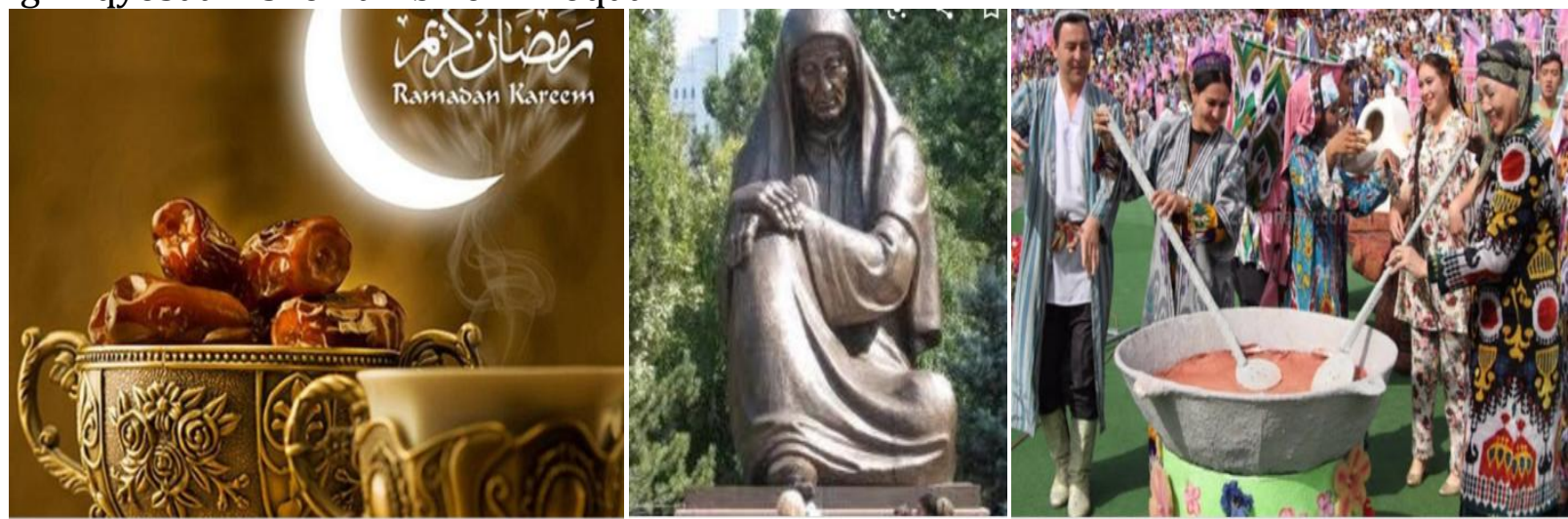

Aslida Qadriyat so'zi “Qadr “ so'zidan olingan bo'lib, ming yillardan buyon insonlar tomonidan qadrlanib kelayotgan rasm-rusumni bildiradi.[4,23] Sobiq sho'ro tuzumi davrida bir qator milliy qadriyatlarimiz taqiqlandi. Ushbu sho'ro tuzumining ayrim rahbarlari o'zbek milliy an'analariga "eskilik sarqiti" deya munosabat bildirib o'zbek xalqining milliy qadriyatlarini oyoqosti qilishdi. Hattoki qozonlarda qaynab turgan sumalaklarni ham ag'darib tashlagani ham hech kimga sir emasdir. Sobiq sovet davrida o'zbek xalqining betakror tarixiy-me'moriy obidalari vayron qilingan, ularning omon qolganlari esa shifoxona yoki omborxonalarga aylantirilgan . Hattoki, o'zbek adiblarining kitoblarini saqlash ham taqiqlandi. Demokritning ushbu so'zlariga e'tibor qarating: "Sen o'tmishga tosh otma. O'tmishga tosh otish, o'likni tepkilash demalkdir. O'lik tirilib, xatolari uchun sendan kechirim so'ramaydi. O'tmishdan saboq olish kerak. Ana shu saboqni xulosalab, bugunni o'ylash kerak".[2,90] Ushbu so'zlardan so'ng shuni anglashimiz mumkinki har bir inson o'z milliy o'zligini unutmasligi kerakdir. Har qanday sharoitda ham qadimiy an'analarimizni asrab avaylab va ularga amal qilishimiz zarur. O'zbek xalqining ajdodlardan avlodlarga o'tib kelayotgan an'analari ham uzoq tarixiy yo'lni bosib o'tishgan. Xalqimizning milliy urf-odatlariga bo'lgan fikrni ushbu so'zlar orqali ham anglashimiz mumkin: "Tarixiy xotirasiz-kelajak yo'q". Qariyib 130 yil avval o'zbek xalqining milliy qadriyatlariga boshqacha munosabat bildirilar edi. Bunga misol qilib, odamlar Ramazon va 
Qurbon hayitini emin erkin nishonlay olishmas edi, ushbu bayramda ishtirok etganlar esa o'tkazilgan majlislarda muhokoma qilinib, izza qilinardi. Ushbu so'zlarga Birinchi Prezidentimiz I. A. Karimov quyidagicha fikr bildiradilar: "Insoniyatning ko'p ming yillik tajribasi shundan dalolat beradiki, dunyodagi zo'ravon va tajovuzkor kuchlar qaysi bir xalq yoki mamlakatni o'ziga tobe qilib, bo'ysundirmoqchi, uning boyliklarini egallamoqchi bo'lsa , avvalambor, uni qurolsizlantirishiga, ya'ni eng buyuk boyligi bo'lmish milliy qadriyatlari, tarixi va ma'naviyatidan judo qilishga urinadi". [1, 25] Darhaqiqat, sho'ro tuzumi davrida Imom Buxoriy, Imom Termiziy singari yuzlab mutafakkir bobolarimizning ma'naviy merosi kamsitildi.[5,68] Milliy qadriyatlar zamirida bir xalqning tarixiy an'analari, turmush tarzi va hayotiy qarashlari mujassam bo'lsa, umumbashariy qadriyatlar butun insoniyatga xos taraqqiyot tajribalarini, har bir odamning bashar farzandi ekani bilan bog'liq umumiy mohiyatni ifoda etadi. Shukurlar bo'lsinki, 1991-yil 31-avgustda O’zbekistonning Birinchi Prezidenti I. A. Karimov butun jahonga yurtimizning mustaqilligini barilla, dadil e'lon qildi. Elyurtimizning buyuk madaniy merosi, ma'naviy qudrati, mustahkam irodasi uning hamisha milliy va umumbashariy qadriyatlarga tayanib yashagani natijasidir. Insonparvarlik umumbashariy qadriyatlarning negizini tashkil etadi. Nazarimda, bizni ming yillar davomida balo-qazolardan asrab kelgan ham shu udum, an'ana, xalqona donishmandlik namunasi bo'lgan buyuk didaktikadir . Hammamizga ma'lumki, hech bir millatni tarixiy qadriyatlarsiz va an'analarsiz tassavur etish qiyindir.[3,1] Milliy udumlar bu ma'lum bir xalqning uzoq yuz yillar davomida shakllangan an'analaridir. [2,17] Har bir xalq o'zining milliy udumlari ajralib turadi. Muhtaram Birinchi Prezidentimiz I. A. Karimov ta'kidlaganlaridek: "O'z tarixi va qadriyatlarini bilmagan inson kelajagini tasavvur qilish qiyindir". Ushbu fikrlardan so'ng shuni anglashimiz mumkinki avvalambor inson o'zligini ya'ni milliy qadriyatlarini bilishi lozimdir.

\section{Adabiyotlar:}

1. Karimov I. Yuksak ma'naviyat - yengilmas kuch. -Toshkent: Ma'naviyat, 2008. -108 b.

2. Qo'chqorov R. Nishonova S. Musurmonova O. Qarshiboyeva M. Milliy istiqlol g'oyasi va ma'naviyat asoslari 6-9. -Toshkent: Ma'naviyat, 2015. -128 b.

3. Mahmud Sattor. O'zbek udumlari . -Toshkent: Cho'lpon, 2007. -192 b.

4. O'rta asrlar Sharq allomalari va mutafakkirlarining tarixiy merosi, uning zamonaviy sivilizatsiya rivojidagi roli va ahamiyati . -Toshkent: O’zbekiston, 2014. -368 b.

5. Karimov I. O’zbekiston Mustaqillikka erishish ostonasida . - Toshkent: NMIU, 2011. -265 b.

\section{„BONJOUR” - XUSHMUOMALALIK IFODASI SIFATIDA}

\section{Mustofoqulov Farhod Samarqand davlat chet tillar instituti o'qituvchisi Email:mustofoqulov@samdchti.uz}

Insonlarning o'rtasidagi o'zaro hurmat va axloqiy qoidalar asososida taraqqiy etgan jamiyatda mustahkam o'rnatilgan qonun-qoidalar hamda belgilangan tartiblarsiz yashashning iloji yo'q. Jamiyatda sodir bo'lishi mumkin bo'lgan turli xildagi zo'ravonliklar hamda tartibsizliklarning oldini olish uchun jamiyatdagi har bir shaxs, jamiyat hayotida o'rnatilgan turli xil tartiblar va qoidalarni hurmat qilishi lozim, jumladan xushmuomalali komunikatsiya ham shunday qoidalardalardan biri sanaladi.

Xushmuomalali komunikatsiya inson hayotini yoqimli va yorqin qiluvchi eng oddiy faoliyatlardan biri hisoblanadi. Xushmuomalalik kategoriyasi jamiyatda kishilar orasidagi interaksiya jarayonining shaklini belgilab beradi. Zeroki, xushmuomalalik kategoriyasidan foydalanmay turib xushmuomalali komuniktsiya jarayonini tashkil etishning imkoni yo'q. 
Chunki, interaksiya jarayonining barcha bosqichlarida xushmuomalalik kategoriyasi o'z o'rniga va vazifasiga ega hisoblanadi.

Komunikatsiya jarayonida xushmuomalalik kategoriyasining qo'llanilishi asrlar davomida taraqqiy etib kelgan jarayon bo'lib hozirda ham u taraqqiy etishda davom etmoqda. $\mathrm{U}$ faqatgina davr va madaniyat jihatidangina bir-biridan farq qilishi mumkin.

Xushmuomalali komunikatsiya-bu jamiyatdagi urf-odatlar va komunikatsiya holatiga muvofiq belgilangan mustahkam interaksiya shakli hisoblanadi. Standart xushmuomalalik kategoriyasi elementlari har qanday o'zaro xurmat va tenglik asosida tashlik etiladigan interaksiya jarayonining negizi bo'lib hisoblanadi. Xushmuomalali komunikatsiya jamiyat hayotida insonlarni birlashtiruvchi jihatlardan biri sanaladi.

Xushmuomalali komunikatsiya insonga noqulay vaziyatlardan chiqib ketishiga yordam beradi. Interaksiya jarayonida u ijobiy muhit yaratadi hamda muammoli vaziyatlarni bartaraf etishda ko'mak beradi.

Komunikatsiya jarayonida xushmuomalalik elementlarining o'z ornida qo'llanilishi interaksiyadan ko'zlangan maqsadga ham o'z ta'sirini o'tkazmasdan qolmaydi. Buni quyidagi xushmuomalalikni ifodalovchi „,bonjour-salom” komponentlar misolida ko'rishimiz mumkin.

Bonjour- kun davomida biror bir kishi bilan salomlashganda qo'llaniladi. [1] Ushbu so'z interaksiya jarayonida tinglovchining jinsi, ijtimoiy statusi kabi omillarni inobatga olgan holda bonjour monsieur- salom janob, bonjour madame- salom xonim, bonjour mon ami- salom do'stim shakllarida qo'llanilishi mumkin.

Ushbu xushmuomalalik elementining komunikatsiya jarayonida qo'llanilishi va uning tahlilini quyidagi misol orqali ko'rib chiqishimiz mumkin.

Le client : - Bonjour, j'ai vu cette paire de chaussures dans la vitrine, les aurez-vous en 42 s'il vous plaît ?

Le vendeur : - Bonjour, je vais voir à la reserve, assyez-vous, je reviens de suite.

Le client : - Si vous les aviez en marron, je préfèrerais.

Le vendeur : - Voilà, monsieur, mais je ne les ai qu'en noir, sinon j'ai ce modèle similaire en marron, voullez- vous les essayer?

Le client : - Je me sens bien dedans, je les prends, combien vous dois- je?

Le vendeur : - $50 €$ monsieur.

Le client : - Je peux vous faire un chèque?

Le vendeur : - Oui monsieur, si vous avez une pièce d'identité. ${ }^{1}$

Ushbu misolgan ko'rishimiz mumkinki, bonjour-salom so'zi interaksiya jarayonining boshlanish qismida qo'llaniladigan eng asosiy xushmuomalalik elementi hisoblanadi. Mazmunan u interaksiya jarayonining kirish qismini to'liq qamarab oladi. Shu jahatdan ham ushbu element interaksiya jarayonining mazmunli va maqsadga muvofiq o'tishiga hamda undan ko'zlangan umumiy maqsadga erishilishida muhim ahamiyat kasb etadi.

Umuman olganda bonjour so'zi interaksiya jarayonida eng ko'p qo'llaniladigan xushmuomalalik elementi hisoblanadi negaki, salomlashishsiz komunikatsiya jarayoniga kirishishni va undan ko'zlangan maqsadga erishishning imkoni yo'q.

Interaksiya jarayonida nutqning pragmatik tasirini oshirish uchun bonjour monsieur, bonjour madame, singari iboralar va so'z birikmalaridan foydalanish ham yaxshi samara berishini ko'rishimiz mumkin.

\section{Adabiyotlar :}

1. Maxsudova M. Muloqot psixologiyasi. - Toshkent: Turon- Iqbol, 2006.

2. Dictionnaire mini Larousse. 2018.

3. Ibragimov X., Mamadaliyev A., Mansurov U., Nishonov A., Soatjonov E., Umbarov N. Dictionnaire français- ouzbek. - Tachkent, 2008.

4. www.françaisfacile.fr 


\section{ISPANIYA TIL TURIZMI TAJRIBASINI O'ZBEKISTON TURIZM SOHASIGA YO'NALTIRISH}

\section{Burxonov Utkir \\ Samarqand davlat chet tillar instituti o'qituvchisi \\ Email: utkirjon24@mail.ru}

Annotation: Today, language tourism is one of the most productive areas of tourism in developed countries, including Spain. The development of this sector in tourism is assessed by having a well-thought-out program in all respects. Such destinations do not have a strong place in Uzbek tourism. Of course, this is directly related to the position of the Uzbek language among the world's languages. The economic potential of language tourism is reflected in the number of summer courses organized by some countries. The purpose of this article is to study the achievements and shortcomings of Spanish language tourism, its adaptation to the conditions of Uzbekistan and its development.
Key words :

language

tourism,

sector in

tourism the

conditions of

Uzbekistan

Bugungi kunda til turizmi degan tushunchadan turizm orqali o'z tili va madaniyatini targ'ib qiluvchi mamlakatlarda, xususan Ispaniya turizmida keng foydalanilmoqda. Tilturizmining obyekti - butildir. Ona tili sifatida ispan tili dunyoda xitoytilidan keyin ikkinchi o'rinda turadi. Shuningdek, ispan tili dunyoda eng keng tarqalgan tillar orasida ham ikkinchi o'rinda turadi. Servantes institutining 2018 yildagi hisob-kitoblariga ko'ra, ispan tilideyarli 480 milliondan ortiq insonlarning ona tilisi hisoblanadi. Uni xorijiy til sifatida o'rganganlar umumiy soni 577 milliondan oshadi, boshqacha aytganda dunyo aholisining 7,6 foizi. Shuningdek, ispan tili internetda ko'p foydalaniladigan tillar orasida uchunchi o'rinda turadi. Ispan tilida so'zlashuvchilar soni ortib borishi bilan ispan tilining mavqeyi kundan-kunga oshib bormoqda.

Hozirgi kunda ispan tili 21 mamlakatda rasmiy til hisoblanadi, borgan sari ispan tilining unga ikkinchi til sifatida qiziqishi tobora ortib bormoqda. Servantes institutining 2018 yilgi hisoboti shuni ko'rsatdiki, dunyoda 22 milliondan ortiq talaba ispan tilini ikkinchi til sifatida o'rganishni tanlagan. Ispan tilini o'rganishga bo'lgan qiziqish sayyohlikning ma'lum bir turini (til turizmi) keltirib chiqardi, uning asosiy maqsadi aynan shu tilni o'rganishdir. Tilning demografik ahamiyatidan tashqari, yana bir narsani alohida takidlash joizki, Ispano-Amerika mamlakatlari madaniyati til o'rganuvchilarning ispan tilini o'rganishdagi eng asosiy sabablaridan biri hisoblanadi.

Ushbu madaniy turizmning ahamiyati, uning o'ziga xos xususiyatlari kundan kunga o'sib borayotganligi, shuningdek, iqtisodiyotga samarali ta'sir o'tkazishiga qaramay, til turizmi bo'yicha dunyo miqyosida kam tadqiqotlar olib borilmoqda 0'zbekistonda esa bu borada deyarli ilmiy tadqiqotlar uchramaydi. Shuning uchun ham tashkilotlarda (til maktablari, sayyohlik agentliklari, mahalliy tashkilotlar va boshqalar) va ilmiy sohalarda ham ushbu masalani ko'rib chiqish kerak. Albatta, til turizmini rivojlantirishdan oldin, tilni rivojlantirish, unga erkinlik berish va uni dunya hamjamiyati tomonidan qiziqish uyg'otish zarurdir. Yuqorida keltirgan ma'lumotlarimiz orqali ispan tilining dunyo aholisi tomonidan juda katta qiziqish borligini va buning natijasida til turizmini rivojlanib borayotganligini ko'rishimiz mumkin. O'zbekistonda turizmning bu yo'nalishini rivojlantirishdan oldin, o'zbek tiliga e'tibor qaratish, unga keng imkoniyatlar yaratish va betakror madaniyatimiz orqali sayyohlarga tilimizga bo'lgan qiziqishni ortirish maqsadga muvofiqdir. So'ngi yillarda o'zbek tiliga bo'lgan e'tibor har qachongidan ham ortgan. Jumladan, O'zbekiston Respublikasi Prezidentining "Alisher Navoiy nomidagi Toshkent davlat o'zbek tili va adabiyoti universitetini tashkil etish to'g'risida" 2016yil 13-maydagi PF-4797-sonli farmoni qabul qilindi. Unga ko'ra, O’zbek tili va adabiyotini, uning o'ziga xos xususiyatlari, ilmiy-nazariy, falsafiy-estetik asoslarini, zamonaviy ta'lim texnologiyalarini chuqur o'zlashtirgan, davr talablariga javob beradigan yuksak malakali ilmiy 
va pedagog kadrlar tayyorlashasosiy maqsadlardan biri qilib ko'rsatilgan ${ }^{1}$ va bu albatta, o'zbek tilini biladigan va uni o'qita oladigan yetuk mutaxasislarni tayyorlash borasida eng ishonchli qadamlardan biri bo'ldi. Shuningdek,O'zbekiston Respublikasi Prezidentining "O'zbek tilining davlat tili sifatidagi nufuzi va mavqeyini tubdan oshirish chora-tadbirlari to'g'risida" 2019-yil 21-oktabrdagi PF-5850-son Farmoni o'zbek tilining moddiy-texnik bazasini yaratish borasida eng ahamiyatli hujjatdir. Ushbu Farmonda davlat rahbari: “O‘zbek tilining qo'llanish doirasini kengaytirish, mamlakatimizda yashayotgan turli millatlarga mansub vatandoshlarimizning davlat tilini o'rganishlari uchun tegishli sharoit yaratib berish, yurtimizda va xorijda o'zbek tilini o'rgatadigan o'quv markazlarini ko'paytirish zarur" - degan fikrlari til turizmini tashkil etish va uni rivojlantirish borasida ahamiyatlidir.

Tilni o'rganish sayohat qilish uchun asosiy turtki bo'lsa ham, sayyohlar manzilni tanlashda boshqa xususiyatlarni, masalan, xavfsizlik, tilning sifati yoki madaniy diqqatga sazovor joylarni hisobga olishadi ${ }^{3}$.Bu esa o'z navbatida turizmning boshqa sohalarini kuchaytirishni taqoza etadi. Albatta, xavfsizlik vasayyohlarning madaniy diqqatga sazovor joylarga tashrifi uchun qulay shart sharoitlar yaratish borasida ham keng va amaliy ishlar amalga oshirildi. Jumladan, O'zbekiston Respublikasi Prezidentining 2019 yil 6 martdagi "Transport va turizm ob'ektlarida jamoat xavfsizligini ta'minlashning samarali tizimini joriy etishga oid qo'shimcha chora-tadbirlar to'g'risida"gi PQ-4229-sonli Qarori va O'zbekiston Respublikasi vazirlar Mahkamasining 2017 yil 23 noyabrdagi "Buxoro, Samarqand, Xiva va Shahrisabz shaharlarida xavfsiz turizmni ta'minlash chora-tadbirlari to'g'risida"gi 939-sonli Qarori mamlakatimizda turizmni jadal rivojlantirish borasidagi sa'y-harakatlar jarayonida xavfsiz turizmni ta'minlash borasida muhim qadamlardan biri hisoblanadi.

Til turizmining yana bir asoslaridan biri bu mavjud tilda jahon standartlariga mos bo'lgan, CEFR talablariga javob bera oladigan til o'rganish normalarining mavjudligi. Ispan tilida bunday mezonlarga javob beruvchi (Chet tili sifatida ispan tili diplomi) DELE til bilish darajasini aniqlab beruvchi xalqaro tan olingan diplom mavjud bo'lib, u 2002 yildan buyun Ispaniya Qirolligi ta'lim, madaniyat va sport vazirligi nomidan Servantes instituti tomonidan belgilangan 4 imtihondan o'tgan talabgorlarga beriladi. Ispaniyaga til o'rganish maqsadida tashrif buyuruvchi sayohlar diplom olish uchun aynan mazkur til (DELE) imtihonini topshirishlari kerak bo'ladi. Afsuski, bugungi kunda o'zbek tili bo'yicha bunday talablarga javob beruvchi imtihon ham diplom ham mavjud emas. Albatta bu borada ham amaliy ishlar boshlangan.

2020 yildan 0‘zbekistonda o'zbek va rus tilini bilish darajasini aniqlaydigan testlar amaliyotga tatbiq qilinishi va malaka darajasi to'g'risida sertifikat berish joriy etilishi kutilmoqda. "CEFR talablariga muvofiq davlat (o'zbek) tili hamda rus tilini bilish darajasini baholash bo'yicha B1 va B2 darajali test savollari ishlab chiqildi. 3ta variantda tayyorlangan testlar Bank-moliya, Davlat boshqaruvi akademiyasi tinglovchilari va DTM xodimlari ishtirokida aprobatsiyadan o'tkazildi. Aprobatsiya natijalari statistik tahlil qilindi hamda bu tahlil xulosalari Vazirlar Mahkamasiga taqdim etilgan. Test savollari takomillashtirilgach, 2020 yildan ularni amaliyotga tatbiq etish rejalashtirilmoqda5. 0'zbek tilining CEFR talablariga mos shaklini yaratish, o'zbek tilini o'rganmoqchi bo'lgan va umuman, o'zbek tilidagi bilim darajasini aniqlamoqchi bo'lganlar uchun birmuncha imkoniyatlar yaratadi. CEFR talablariga javob beradigan o'zbek tilini o'qitish tizimini yaratish ham maqsadga muvofiqdir. Bunga sabab

\footnotetext{
${ }^{1}$ https://navoiy-uni.uz/uz/site/about?id=1

2 https://www.gazeta.uz/oz/2019/10/22/uzbek-language/

${ }^{3}$ María Redondo-Carretero, Carmen Camarero-Izquierdo, Ana Gutiérrez-Arranz, Javier Rodríguez-Pinto: "Language tourism destinations: a case study of motivations, perceived value and tourists' expenditure" - SpringerScience+Business Media New York 2017

${ }^{4}$ https://examenes.cervantes.es/es/dele/que-es

5 https://kun.uz/uz/news/2019/12/28/2020-yildan-ozbekistonda-ozbek-va-rus-tilini-bilish-darajasini-aniqlaydigan-testlaramaliyotga-tatbiq-etilishi-kutilmoqda
} 
sifatida kuzatuvlarim natijasida shuni aytishim mumkinki, O'zbekistonga tashrif buyurgan 5 $10 \%$ sayyohlarning o'zbek tilini bilishga va uni o'rganishga bo'lgan qiziqishi mahalliy aholi bilan bo'lgan jonli muloqatdan so'ng yanada ortadi va tabiiyki, ularda o'zbek tilini o'rganish bo'yicha dasturlar va imtihonlar shakli haqida bir qancha savollar tug'iladi. Ularga o'zbek tilining jahon standardlariga most qulay materiallarni taqdim etish, o'zbek tilini o'rganuvchilar auditoriyasini oshirishga va til turizmini rivojlantirishga hizmat qiladi.

Iqtisodiy hamkorlik va rivojlanish xalqaro tashkilotning ma'lumotlariga ko'ra bugun turizm rivojlanib borayotgan bir vaqtda madaniy turizm eng yirik va eng tez rivojlanayotgan global turizm bozorlaridan biri hisoblanadi. Ko'plab mamlakatlar o'zlarining moddiy va nomoddiy madaniy boyliklarini tobora rivojlanib borayotgan raqobatbardosh turizm bozorida qiyosiy ustunliklarni taraqqiy ettirish va globallashuv sharoitida mahalliy o'ziga xoslikni yaratish vositasi sifatida faol rivojlantirmoqdalar.Madaniyat manzilning o'ziga xosligini yaratadi, turizm esa madaniy meros va madaniy ishlab chiqarishni kuchaytiradigan daromadni oshirishi mumkin.Turizm va madaniyat o'rtasidagi bu o'zaro bo'gliqlik asosida, boshqalarning madaniyatini his etish uchun sayohat qilish tushunchasi muhim o'rin egalaydi.

Madaniy turizmning ko'lami katta. Madaniy iste'mol qilish imkoniyatlari kengayganligi sababli madaniy turizmning xilma-xilligi o'sib bormoqda. Madaniy taklif madaniyat obyektlari, hunarmandchilik, arxitektura namunalari, ijrochilik san'ati, madaniy tadbirlar, ijodiy faoliyat va nomoddiy meroslarni o'z ichiga oladi ${ }^{1}$. Shuningdek, odamlarning turmush tarzi, kundalik madaniyati va urf-odatlari bilan tanishish ham madaniy turizmga misol bo'la oladi.

O'zbekiston turizmining asosini madaniy turizm tashkil etadi. Chunki, O'zbekiston boy tarixiy-madaniy merosga ega bo'lib, jumladan 7300 dan ortiq qadimiy-me'moriy va arxeologik obidalar mavjud. Ularning ko'pchiligi Samarqand, Buxoro, Xiva, Shahrisabz, Termiz, Qo'qon va Toshkent shaharlarida joylashgan. Yurtimizning 200 dan ziyod tarixiy yodgorliklari va obidalari YUNESKOning madaniy merosi ro'yxatiga kiritilgan.

Til turizmini madaniy turizmga kiritish mumkin. Til turizmining tushunchasi Ispaniya Turistik Kengashi tomonidan (Ispaniya Chet Tili sifatida Ispaniyaning Maktablar Uyushmasi Federatsiyasi [FEDELE]) ilk bora Ispanyada qo'llangan bo'lib, ular odatdagi sayohat turlaridan farqli ravishda, sayohatlar davomida boshqa manzillarda bo'lib turgan sayohatchilar tomonidan amalga oshiriladigan turistik faoliyat deb tushuniladi. Ushbu sayohat chet tilini o'rganish va u bilan shug'ullanish uchun doimiy yashash muddati bilan bir yildan kam bo'lmagan davrda amalga oshiriladi. Albatta, chet tili o'rganish dasturiga va sayohatchining til bilish darajasiga qarab muddat bir yildan ham kam bo'lishi mumkin.

Turizmdagi ushbu yo'nalishining moliyaviy ta'siri boshqa tarmoqlar uchun ham muhimdir. Tilni o'rganish diqqatga sazovor joylarni ziyorat qilish va ijtimoiy-madaniy ahamiyatga ega bo'lgan joylarga tashrif buyurish, shuningdek xizmatlar va sport faoliyati, mehmondo'stlik, oshxona va hordiq kabi qo'shimcha mahsulotlarni sotib olish bilan birlashtiriladi. Bunday yo'nalishni bizning yurtda rivojlantirish ham iqtisodiy, ham madaniy rivojlanishga zamin yaratadi.

\section{Adabiyotlar :}

1. María Redondo-Carretero, Carmen Camarero-Izquierdo, Ana Gutiérrez-Arranz, Javier Rodríguez-Pinto: "Language tourism destinations: a case study of motivations, perceived value and tourists' expenditure" - Springer Science + Business Media New York 2017

2. https://navoiy-uni.uz

3. https://examenes.cervantes.es

4. https://kun.uz

\footnotetext{
${ }^{1}$ María Redondo-Carretero, Carmen Camarero-Izquierdo, Ana Gutiérrez-Arranz, Javier Rodríguez-Pinto: "Language tourism destinations: a case study of motivations, perceived value and tourists' expenditure" - SpringerScience+Business Media New York 2017
} 


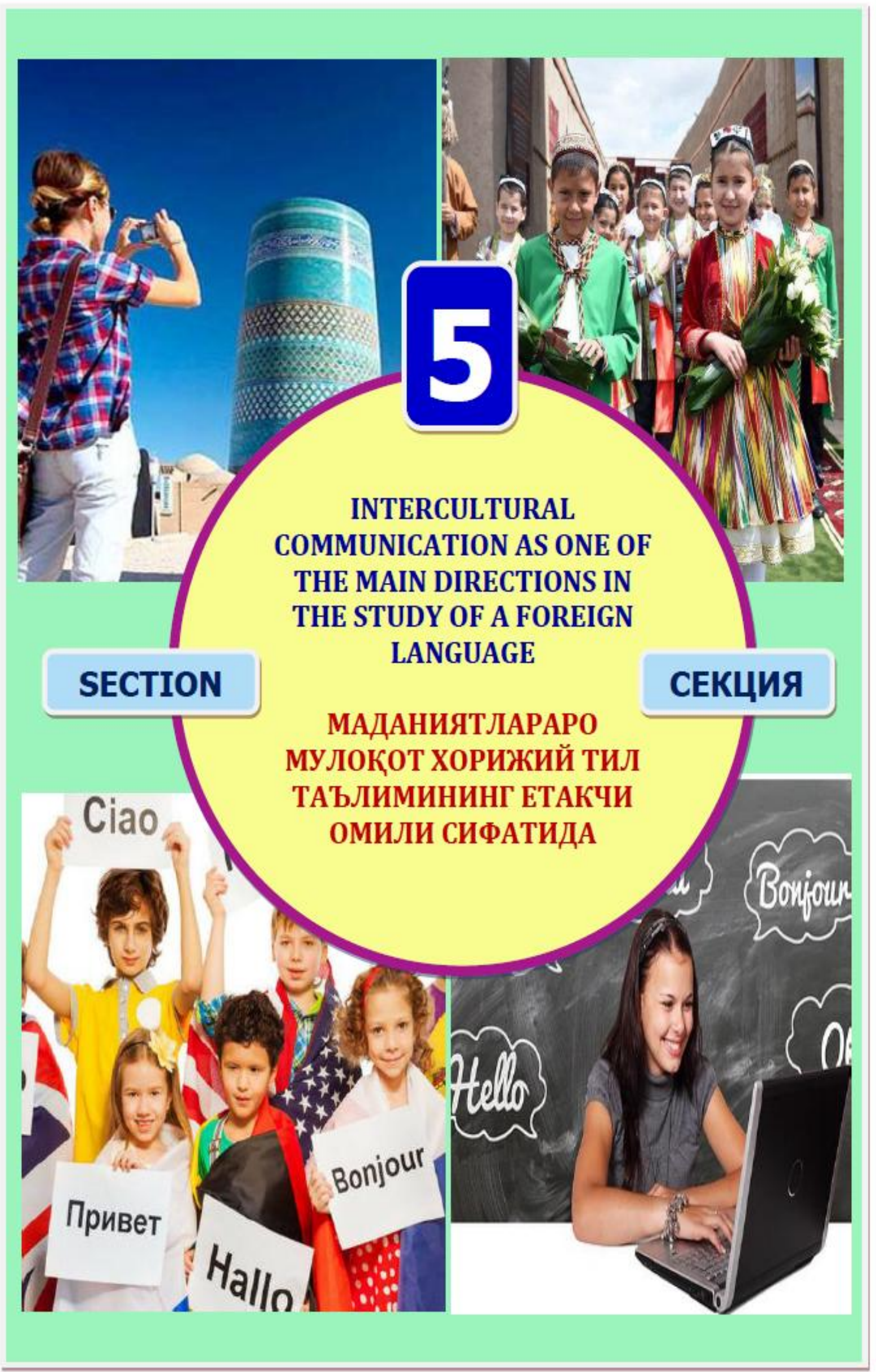




\section{PARTICIPANTS :}

1. Ли Чэньсюй

Преподаватель Института

Конбучия при СамГИИя

2. Miriam Fopiani Roman Professeure d'espagnol et de français de l' institut des langues etrangeres de Samarkand

3. Hashem Esmael Ali

(Misr Arab Respublikasi)

4. Alamov Shavkatjon

(SamDCHTI)

5. Lucie Lavoisier

Professeur de l'Institut des

langues étrangèrtes de Samarcande

6. Djuraeva Gavhar Normuratovna Lecturer at "Silk Road" International University of Tourism

7. Giyasova Umida Erkinovna

Scientific researcher, Head scientific and methodological center

8. Ибрагимова 3. Урганч Давлат Университети катта ўқитувчиси

9. Абдуллаева Г. Урганч Давлат Университети катта ўқитувчиси

10. Исраилова Дилором

Шомахаматовна

ўзджту ўқитувчиси

11. Кучибоев Мансур Абдумуротович СамДАҚИ ўқитувчиси

\section{ИШТИРОКЧИЛАР:}

12. Хамраев Озод Мелиевич СамДАқИ ўқитувчиси

13. Отамуродова Дилафруз Рахмановна ЎзДжТУ катта ўқитувчиси

14. Ummatova Xonimoy Amonovna Samarqand viloyati Jomboy tumani 40 -IDUM o'qituvchisi

15. Holmatova Gulnoza Bahtiyor qizi Uzbek State World Languages University, teacher

16. Юсупова Дилфбуза Икромовна ЎЗДЖТУ мустақил тадқиқотчиси, Гёте-Институти ўқитувчиси

17. Pulatova Nigina Aminovna SamDCHTI o'qituvchisi

18. Avliyoqulova Muqaddas Buxoro viloyati G'ijduvon tumani 17- maktab o'qituvchisi

19. Hayitov To'ymurod Vohid o'g'li SamDU 1-bosqich talabasi

20. Narzullaeva Farzona Farhodovna Student of Samarkand State Institute of Foreign Languages

21. Sattorova Fazilat Ermamatovna Samarkand State University, phd doctorate

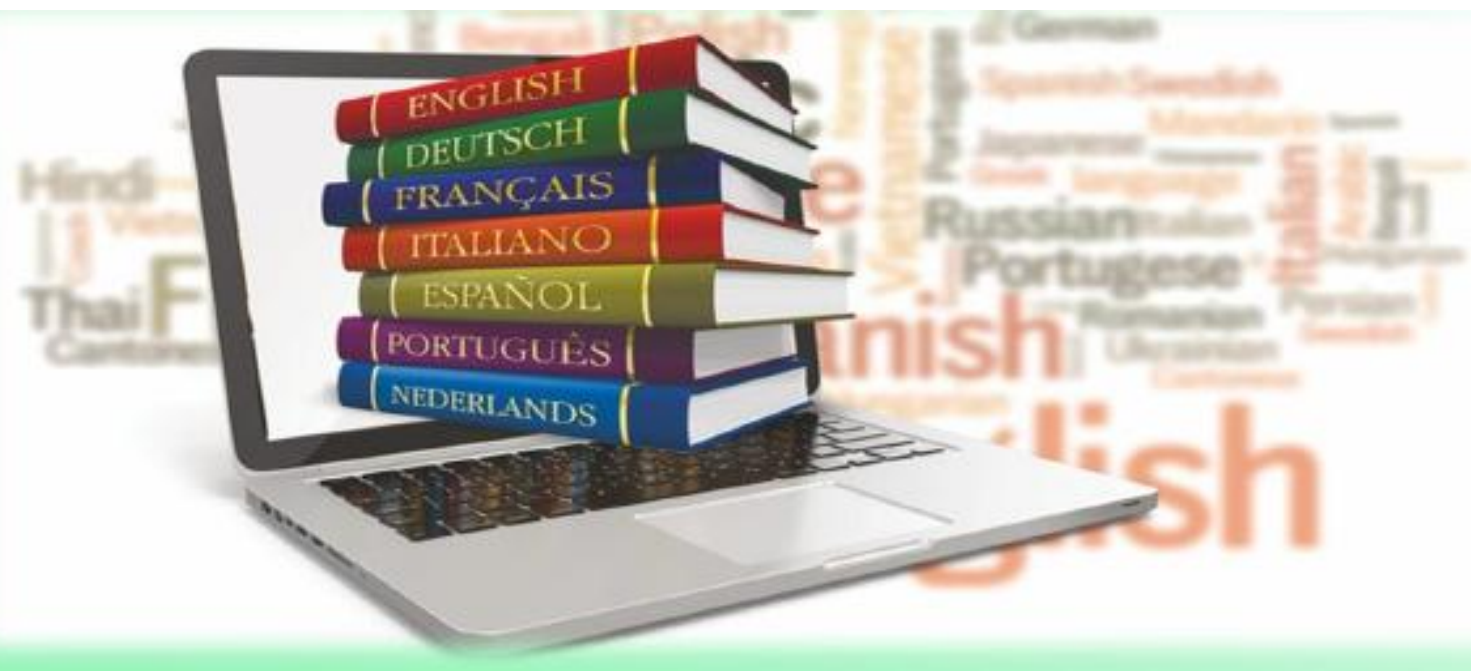




\section{МЕЖКУЛЬТУРНАЯ КОММУНИКАЦИЯ \\ В ПРЕПОДАВАНИИ ИНОСТРАННОГО ЯЗЫКА}

Ли Чэньсюй

Преподаватель Института

Конбуция при СамГИия

李晨旭

撒马尔军国立外国语学院孔子学院

\begin{abstract}
Annotation: Intercultural communication is ubiquitous in and indeed an indispensable part of foreign language teaching, which has been acknowledged by many experts and scholars of foreigh language teaching. This paper elaborates on the topic of intercultural communication from three aspects, the relations between foreign language teaching and intercultural communication, the neccessities of the teaching of intercultural communication in foreign language teaching, and training strategies to nurture students' awareness of intercultural communication in foreign language teaching.
\end{abstract}

Key words : foreign language teaching, intercultural communication, training strategies

В преподавании иностранного языка широко распространен межкультурный феномен. Обучение иностранным языкам и межкультурная коммуникация неотделимы, об этом многие эксперты и ученые пришли к единому мнению.

\section{1.Связи между преподаванием иностранного языка и межкультурной коммуникацией}

«Межкультурная коммуникация» понимается общением между носителями языка и не носителями языка, а также любым общением между людьми из разных языков и культур. Язык является символом культуры, и языки разных народов отражают и документируют различные этнокультурные стили. Культура разных народов, в свою очередь, в какой-то степени сдерживают развитие их языков. По мнению Л. А. Уайта, язык является носителем культуры, и культура каждого народа наиболее полно и совершенно отражается в своем языке. Язык, как носитель национальной культуры и знаний, и хранилищ коллективного опыта, всегда целостно и слаженно отражает культуру на всех этапах ее развития, и ее фиксирует, передает ее из поколения в поколение. Из-за тесной связи языка и культуры обучение иностранному языку неизбежно влечет за собой преподавание культуры и, конечно же, не может обойтись без изучения и понимания культуры страны-объекта языка.

Межкультурная коммуникация является целью изучения иностранного языка, в связи с этим, с самого начала мы должны с этой целью заниматься преподаванием иностранных языков. Конечная цель преподавания иностранного языка состоит в том, чтобы учащиеся использовали изученные знания в реальной коммуникации. Если учащиеся не обладают глубокими знаниями о культуре на фоне другого языка, они только могут общаться с иностранцами своими мышлениями, обычаями и мировоззрениями, сформированными в своей родной культуре, и не могут войти в ту же культурную среду иностранцев. В процессе их коммуникации легко возникает недоумение и непонимание, что делает общение неудачным.

\section{2. Необходимость преподавания межкультурной коммуникации в процессе обучения иностранному языку}

Язык и культура тесно связаны друг с другом. С одной стороны, язык является частью культуры, а также носителем культуры. С другой стороны, культура сдерживает язык.

Различные языковые и культурные контексты приводят к различиям в различных аспектах языка, таких как грамматика, лексика, идиомы и т. д. 
Необходимостью является акцент на преподавание межкультурной коммуникации в обучении иностранным языкам.

Во-первых, интеграция межкультурного коммуникативного сознания в преподавание иностранного языка помогает учащимся использовать и понимать сам язык при изучении иностранного языка. По мнению Н. Келли, культура разделена на два уровня. К одном уровню относится культура «С», то есть литература, искусство, философия и техника. К другому уровню относится «жизнь человека», обозначающая обычаи, традиции и общественные организации. Культура не является независимой дисциплиной, а является частью преподавания языков. Язык и культура зависят друг от друга. Таким образом, акцент на межкультурной коммуникации в обучении иностранному языку способствует более полному изучению иностранного языка.

Во-вторых, если в процессе преподавания иностранного языка акцентируется преподавание межкультурная коммуникация, в реальном языковом общении можно избежать речевых ошибок. Речевая ошибка разделена на два типа: ошибку грамматики и ошибку понимания культуры. В преподавания иностранного языка учителям необходимо не только обучать учащихся правильной грамматике, но и объяснить культуру на фоне другого языка. Таким способом, когда учащиеся общаются с иностранцами, они не могут попасть в смешное положение из-за неправильного использования слов и непонимания культурного контекста.

\section{3. Способы развития сознания межкультурной коммуникации у учащихся в процессе преподавания иностранного языка.}

Во-первых, необходимостью является повышение культурной грамотности самого педагогика. В широком смысле межкультурное знание охватывает все аспекты, такие как политика, экономика, история, география, литература, религия, обычаи, этика, нравственность, мораль, психология и социальная жизнь. В узком смысле, повседневные слова, собственные имена, идиомы, народные пословицы и т. д., а также молчаливые языки, такие как движение тела, мимика, могут отражать большое количество межкультурных знаний. Будучи учителем иностранного зыка, в будние дни должно часто читать газеты и журналы на иностранном языке, смотреть телевизор, слушать радио или общаться с иностранными друзьями, постоянно фокусироваться на том, что происходит в стране изучаемого языка, чтобы адаптироваться к требованиям обучения межкультурной коммуникации.

Во-вторых, изменение образа мышления и понимание культурных коннотаций также являются важными. Из-за различных способов мышления разных национальностей отличаются культурные коннотации некоторых культурных символов, в связи с этим, часто возникают трудности в процессе межкультурной коммуникации, что влияет на коммуникативный эффект, и вызывает некоторые недоразумения. Таким образом, в преподавании необходимостью является развитие способности у учащихся к пониманию и восприятию образа мышления иностранцев, и культурных коннотаций различных культурных символов.

В-третьих, учителя должны внедрять инновационные методы обучения и укреплять межкультурную коммуникативную компетентность. Для достижения лучших результатов межкультурной коммуникации необходимо внедрять инновации в методике обучения. В процессе формирования межкультурной коммуникативной компетентности у учащихся эффективными являются эмпирическая педагогика, индуктивно-перечислительная педагогика и интерактивная педагогика задач.

Межкультурная коммуникация имеет важное практическое значение в обучении иностранному языку. При обучении иностранному языку необходимо уделять особое внимание развитию межкультурной коммуникативной компетентности учащихся, только таким образом учащиеся смогут по-настоящему владеть иностранным языком, и учители смогут добиться наилучших результатов преподавания. 
Литературы:

1.Ху Вэньчжун. Культура и коммуникация. М.: Пекин. Издательство по преподаванию и изучению иностранных языков. 1994.

2.Цзя Юйсин. Межкультурная коммуникация. М.: Шанхай. Издательство по преподаванию иностранных языков в Шанхае. 1997.

\section{UNA EXPERIENCIA INTERCULTURAL: \\ SIMILITUDES ENTRE EL CARACTER ESPAÑOL Y EL CARACTER UZBEKO}

\section{Miriam Fopiani Roman \\ Professeure d'espagnol et de français institut des langues etrangeres de Samarcande}

Annotation: En este breve artículo presento algunas similitudes encontradas entre el carácter de la población uzbeka y el de los españoles; más concretamente parto del cliché sobre el carácter jovial y festivo atribuido a los españoles. Las afirmaciones y asociaciones aquí presentadas deben ser comprendidas como apreciaciones personales que se basan en mi propia experiencia personal $e$ intercultural como profesora de español en Samarcanda, Uzbekistán, durante diez meses. En primer lugar, justifico la elección del tema, y sobre todo, hago algunas aclaraciones sobre los términos utilizados o las ideas expuestas, para más tarde, después de exponer mis apreciaciones, llegar a una conclusión personal.
Key words :

Expérience, Interculturalité, Caractère, Célébration, Espagnols, Ouzbeks

Justificaciones y aclaraciones. Hoy hace nueve meses que me bajé del avión, en la oscuridad de la noche, y me vi en Samarcanda, Uzbekistán, donde pasaría al menos los próximos diez meses. Llegué con la misión de enseñar español en la Universidad Estatal de Samarcanda, pero por diversas circunstancias, comencé también a trabajar como profesora de español y de francés en el Instituto de Lenguas Extranjeras. Puedo asegurar que estoy aprendiendo muchísimo sobre la cultura de los uzbekos y tayikos1 nacidos en este país, y de manera paralela sobre la de los rusos que conviven con ellos. Dada la confluencia de culturas y orígenes presentes en Uzbekistán, he decidido utilizar el término uzbekistano2 para designar a todos aquellos nacidos en Uzbekistán, ya que, a pesar de tener diferentes orígenes, comparten las mismas tradiciones y cultura, en la mayoría de los casos, y forman parte de la misma identidad nacional.

1. En Uzbekistán, y especialmente en Samarcanda y en Bujará, viven muchos tayikos, llamados así no porque hayan nacido en Tayikistán sino porque tienen descendencia tayika, muy diferente a la descendencia uzbeka. A lo largo de la historia, los tayikos (de origen persa) y los uzbekos (de origen turco) han convivido en esta zona de Asia central. Así mismo, la lengua tayika hablada en Samarcanda presenta diferencias al tayiko que se habla en Tayikistán.

2. En muchos textos académicos en inglés se utiliza el término "uzbekistani" para referirse a todo aquel que haya nacido en Uzbekistán, pudiendo tener orígenes tayiko, ruso, azerbaiyano, etc. Sin embargo, debido a la poca investigación académica existente en español sobre el pueblo uzbeko, este término no se ha encontrado en español de manera precedente con tal fin.

Probablemente ningún español se haya parado a pensar que podríamos tener cosas en común con los habitantes de un país tan remoto y desconocido para nosotros, pero a mi parecer hay más de lo que podríamos creer. Aunque de manera general prefiero no entrar en el delicado tema de los clichés, en este caso sí manifiesto estar de acuerdo con algunos de los estereotipos 
asociados al carácter español, como por ejemplo el gusto por la fiesta y la jovialidad. No obstante, es necesario tener en cuenta que los estereotipos hablan de manera general de una comunidad, y no de manera particular, ya que encontraremos muchas personas que no respondan a esta definición de "carácter español". Por eso, no debemos considerar los clichés como verdades absolutas.

Dicho esto, me parecía una pena no plasmar por escrito algunas de mis vivencias, y sobre todo, me parecía curioso e interesante presentar algunas similitudes percibidas entre el carácter de los uzbekistanos y el carácter de los españoles. Por lo tanto, lo que dejo por escrito en este pequeño artículo está basado en mi propia apreciación y experiencia como profesora de español en Samarcanda durante estos nueve meses.

Un carácter alegre y festivo. En cuanto llegué a Samarcanda, mi primera impresión sobre los uzbekistanos fue muy agradable, y debo admitir que los aspectos positivos que remarqué en mi primera semana de expatriada los mantengo aún a día de hoy después de nueve meses. Me encontré con personas muy sociables, con un carácter un poco parecido al español, ya que entablan conversación con todo el mundo. Además, de manera general también percibo lo que llamaríamos en un lenguaje familiar "buen rollo", es una sociedad alegre, de personas risueñas con la que puedes bromear y dar rienda suelta al buen humor, aunque siempre midiendo el tema y las palabras, ya que la mentalidad uzbeka es muy diferente a la española. Todas las mañanas, en la residencia, los trabajadores me dan los buenos días y me preguntan cómo estoy con una enorme sonrisa en la boca, incluso me chocan la mano como buenos colegas. A pesar de la vestimenta seria y formal que todo ciudadano acostumbra adoptar, desde los estudiantes de 17 años a los más mayores, todo ocurre y se construye de manera bastante familiar.

Si continuo hablando sobre la similitud del carácter español con el carácter uzbeko, quizás la más evidente para mí es el festejo. Como cliché de los españoles siempre escucharemos que aprovechamos cualquier excusa para celebrar o montar una fiesta, cosa que tampoco podamos negar que sea cierta, y es que a veces los clichés no son tan clichés, sino que reflejan la realidad. Sin embargo, me atrevo a afirmar que en la cultura uzbeka este aspecto se ve aún más acentuado.

Comenzando por el ámbito personal, todo tipo de acontecimientos como cumpleaños, aniversarios, o graduaciones se celebran con mucha comida y bebida. En el departamento de lengua francesa, cada vez que se acercaba el cumpleaños de algún profesor o profesora, solían comprar una tarta, gran cantidad de samsas, incluso en ocasiones palov, y si era necesario comenzar la clase media hora tarde, no era un problema. Pero la celebración siempre está asegurada.

Cabe destacar, evidentemente, las bodas uzbekas, para las que las familias se llevan toda la vida guardando dinero. Casarse es el principal objetivo de todo uzbekistano, por lo que se pueden imaginar la magnitud de dicha fiesta. En tan solo cuatro meses, desde septiembre que llegué a Samarcanda hasta finales de diciembre que volví a casa por Navidad, asistí al convite de cinco bodas uzbekas, y fui invitada a alguno más al que no pude ir. Para todo aquel que nace en Uzbekistán es muy importante que el día de su boda haya muchos invitados, mucha comida y mucho que beber. Se da prioridad a la cantidad y no a la calidad de invitados para celebrar la mayor fiesta de sus vidas.

Además, pude comprobar que este gusto por la fiesta y las reuniones forman parte de la cultura uzbeka desde hace mucho tiempo. Aproveché el mes de abril, durante la cuarentena, para leer "Historia del gran Tamorlan", la narración escrita por el español Ruy Gonzalez de Clavijo en su embajada a Tamerlan o Amir Timur a principios del siglo XV. Tras un largo viaje de Cádiz a Samarcanda en barco, a pie y a caballo, se encuentran con el emperador turcomongol y, muy a mi sorpresa, durante toda su estancia en Samarcanda Clavijo y sus acompañantes asisten a una fiesta organizada por Amir Timur día tras día. Cada párrafo comienza anunciando un nuevo festejo: 
"E martes siguiente, siete dias del dicho mes de Octubre, el Señor mando facer otra tan gran fiesta [...]" (164: 1782)

"E otro día miércoles siguiente, el Señor mandó facer otra fiesta, é mandó que viniesen allá los dichos embajadores [...]" (164: 1782)

"E jueves siguiente, nueve días del dicho mes de Octubre, Hausada, la mujer de Mirassa Miaxa, el fijo mayor del Señor, fizo una gran fiesta, á la qual mandó llamar á los dichos Emabajadores [...]" (165: 1782)

"E lunes siguiente, que fueron trece días del dicho mes de Octubre, el señor Tamurbec fizo una fiesta, é mandó llevar á los dichos señores Embajadores á ella [...]" (168: 1782)

Sin embargo, este carácter festivo no solo se percibe en el ámbito personal, sino también en el ámbito profesional. Los uzbekistanos conmemoran y celebran todo aquello que significa un auge o un canto a la cultura uzbeka. No han sido pocas las veces que he asistido a "fiestas" o actos oficiales para recordar el nacimiento/muerte de algún intelectual de nacionalidad uzbeka como Alisher Navoi, o para conmemorar la independencia del país. Recuerdo aquel día que llegué a clases y los alumnos me pidieron permiso para ir todos juntos a celebrar El día de la Bandera. Música y bailes alrededor de la gran Bandera uzbeka que se encuentre cerca de la facultad, y todos con una réplica pequeña moviéndola sin parar. Siempre había algún espectáculo en proceso de preparación en el instituto para festejar algún evento, y todas estas fiestas siempre estaban precedidas por un acto conmemorativo oficial en el que el rector del Instituto y otras caras importantes como los decanos dedicaban unas palabras. Por supuesto, este carácter festivo de los uzbekistanos está estrechamente ligado al carácter alegre y social que les caracteriza del que hablábamos al comienzo. No es de extrañar que una de las primeras palabras en ruso que aprendí al llegar fuera "Вечеринка" (vecherinka), que significa "fiesta" en español. Por otro lado, todas mis clases se enmarcaban en un ambiente alegre en el que los estudiantes, no sin dejar de trabajar, se sentían libres de pasarlo bien, gastar bromas y reír. Realizar actividades lúdicas para aprender, como los juegos, era un aspecto de la enseñanza que funcionaba muy bien con los estudiantes uzbekistanos.

Conclusión. Por lo que a mi sorpresa, cuando llegué a este extraño país me encontré con gente con un carácter muy parecido al mío, al de los españoles (sobre todo al de nosotros los andaluces), aunque de mentalidad muy diferente. A pesar de que generalizar siempre será un error, puesto que una nacionalidad no puede definir el carácter de un individuo, me atrevo a decir que el pueblo español y el pueblo uzbeko puede entablar muy buenas relaciones, o al menos pasarlo bien

Partiendo de mi experiencia como base para esta afirmación, me parece muy curioso y un tanto sorprendente constatar que he hecho más y mejores amigos uzbekistanos que franceses en los dos años que he vivido en Francia. A pesar de ser países vecinos y de compartir muchas otras cosas como una lengua de origen común, parte de la historia, etc, me atrevo a decir que el carácter de los franceses dista más del nuestro, y me hace preguntarme de qué depende nuestra personalidad o nuestra manera de interactuar con los demás. Es cuanto menos curioso descubrir que dos países tan diferentes y alejados el uno del otro comparte algunos rasgos sociales, e incluso podríamos considerar que culturales.

\section{Bibliografía:}

1.GONZÁLEZ DE CLAVIJO, Ruy, Historia del Gran Tamerlán. Madrid, Imprenta de Don Antonio de Sancha, 1782. 


\section{Hashem Esmael Ali (Misr Arab Respublikasi) \\ Alamov Shavkatjon \\ SamDCHTI o'qituvchisi}

تعليمية اللغة العربية وفق مقاربات معاصرة للارارسين لهافي أوزبكستان

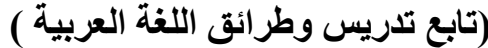

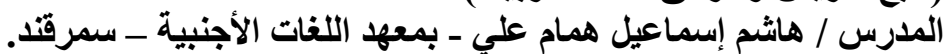
المدرس / أعلوف شوكت جان رحمتوفئش- بمعهد اللغات الأجنبية ـ سمرقند.

إن تعليمبة اللغة العربية وفق مقاربات معاصرة، يؤدي إلى مردود قيم، يتمثل في كسب المتعلم للغة العربية للكفاية التواصلية.

من الواضح أن تعليمية وتدريس اللغة العربية وفق مقاربات معاصرة من القضايا التي شغلت الباحثين والعاملين في مجال تعليم اللغة العربية لغير الناطقين بها، كما شغلت علماء اللسانيات العربية واللسانيات التطبيقية واللسانيات التعليمية منذوقت وقت بعيد، يعمل كل هؤلاء برغبة ودافع عميق في تطوير تعليم اللغة العربية وبخاصة في عصرنا هذا - عصر الثورة المعرفية والتكنولوجية والبرمجة الحديثة المتطورة، نرى ذلك واضحا في استثمار ما جاءت به النظريات اللغوية واللسانية التربوية الحديثة في ذللك المجال، أضف إلى ذلك مسألة الحفاظ والدفاع عن الخلفية المعرفية لهذه اللغة؛ حتى نحمي مستعمليها من كل مظاهر الإنحراف اللغوي كاللحن وغيره من الإشكاليات التي نؤثر سلبا على الحفاظ على تعليم وتقويم ألسنة الناطقين بغيرها، ولذلك تأتي تعليمية وتدريس اللغة العربية وظيفيا وتواصليا للحد من هذه المظاهر حفاظا على مكانة اللغة العربية في حياة الثعوب وحضارتها وتراثها العلمي والثقافي.

يقول عمار : ( وقد شهد ميدان تعليم اللغات اهتماما كبيرا بتطوير مناهج تدريس اللغات الأجنبية وطرائقها، استجابة لللراسات اللغوية والنفسية، والتيارات النظرية الجديدة التي ركزت على المتعلم، والعملية النواصلية في تعليم اللغة، ودعت إلى لى تجاوز تعليم القواعد المجردة، في إطار مايسمى التعليم عن اللغة إلى مستوى أعمق يركز على تعليم التواصل باللغة، وممارسته

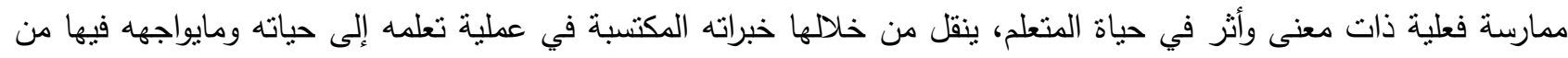

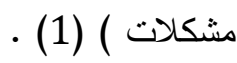

من الواضح أن هناك جهود كبيرة بذلت وتبذل للدفاع عن اللغة العربية وتقويم ألسنة الناطاقين بها أو بغيرها، لكن كل هذه الجهود غير كافية، وأمام هذه التحديات سنلقي الضوء على إحدى قضايا اللغة العربية، من زاوية بيداغوجية تعليمية، لما لهاذين المجالين الحيويين، من أهمية معرفية وتطبيقية ، ساعدا في حلول ومعالجة كثير من القضايا اللسانية، كانت لها نتائج إيجابية وبخاصة ونحن نعيش أزمات لغوية معقدة كالعولمة وأزمة تعليمية اللغة.

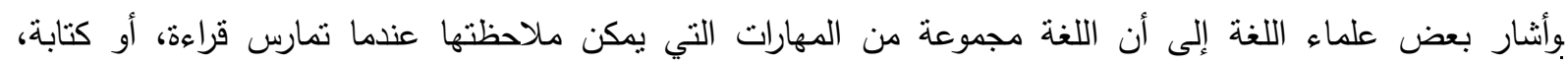

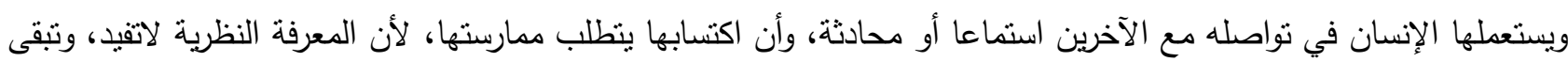
ناقصة إن لم تكن ثمرتها النطبيق، والتعبير السليم. من هنا يتضح لنا أن المظاهر التي تتبين من خلالها أن مستعملي اللغة العربية ينقصهم التحكم في آلياتها الوظيفية عند استعمالها حيث اتضح لنا أن غالبية ومعظم هذه الظواهر المرضية لاتعود إلى اللغة العربية بقدر ما تعود إلى متكلميها أو متعلميها ، وربما بتعلق الأمر بعدة أسباب كـــ : 1. المناهج والمضامين البيداغوجية التي تقدم لمتعلميها. 
2. دور المدرس ، وطريقة التدريس في عملية التعليم. 3. تعديل سلوك المتعلم واكسابه القدرة على تعديل هذا السلوك والتكيف مع مجتمع وليه وبيئة التعلم. 4. الوسائل المستعملة في العملية التعليمية للغة العربية. 5. طرائق واستراتجيات تقويم العملية التعلمية. فعند العودة إلى المناهج المعدة في تعليم اللغة العربية نجد أن أغلبها لايقوم على قواعدات على علمية، فالمناهج مضطربة ويكثر

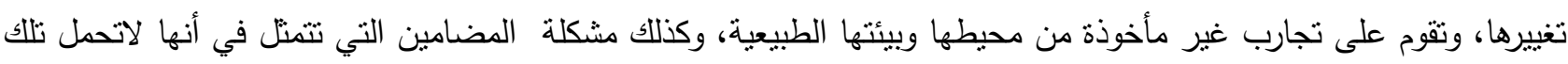

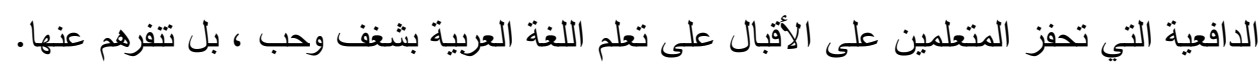

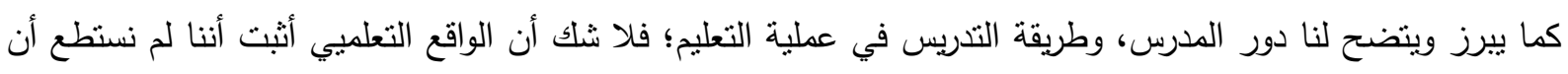

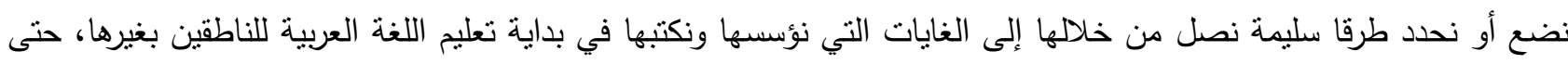
يتمكن المتعلم من التحكم ولو بقدر يفتح له الطريق في بدايته عند تعلم اللغة العربية ، اكتسابا للكفاية التواصلية عند توظيفها.

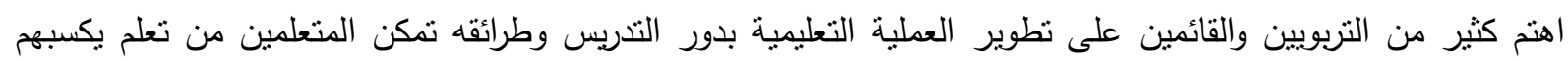
المهارات اللغوية التي تحقق أهدافهم.

أما فيما يتعلق بتعديل سلوك المتعلم واكسابه القدرة على تعديل هذا السلوك والتكيف مع مجتمع وبيئة التعلم؛ فالمتعلم الأجنبي يواجه الكثير من المشاكل عند تعلمه وخاصة أنه لم يعش في بيئة اللغة العربية ولا محيطها الثقافي.

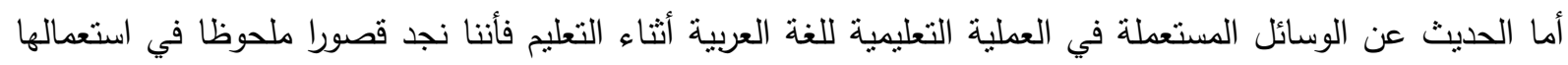

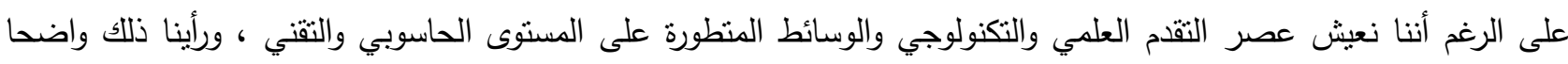

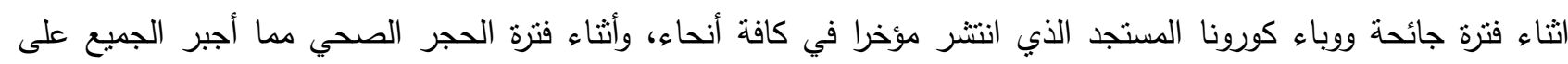
استخدام هذه الوسائل للتعليم عن بعد، وخلال ذلك ظهرت عيوب كثثرة في استخدام هذه الوسائل على الرغم من أهميتها القصوى.

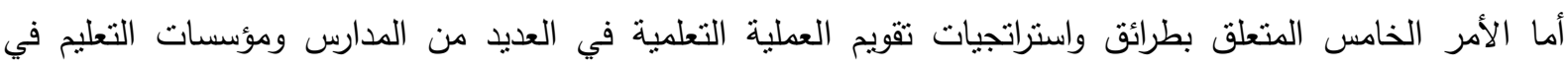

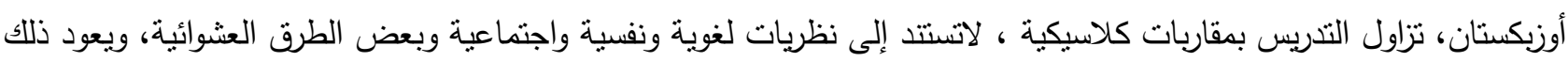

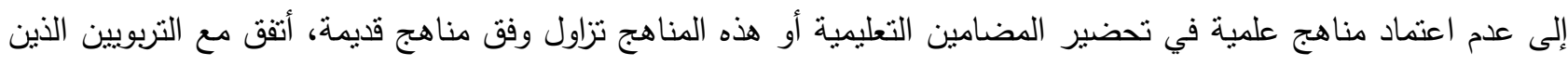
يدعون إلى ابتكار طرائق واستراتجيات جديدة تمكن الدارسين من تعلم يكسبهم المهارات اللغوية التي تحقق أهدافهر.

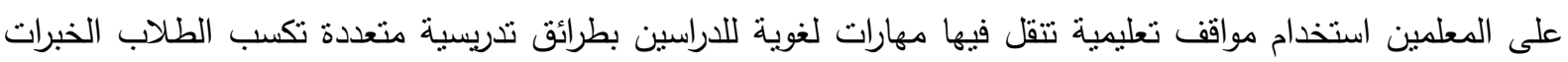

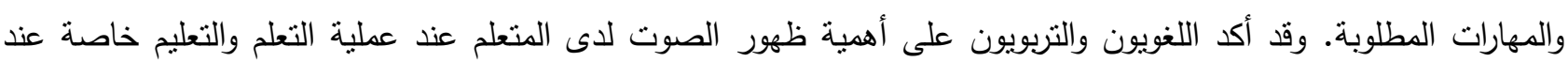

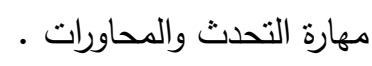

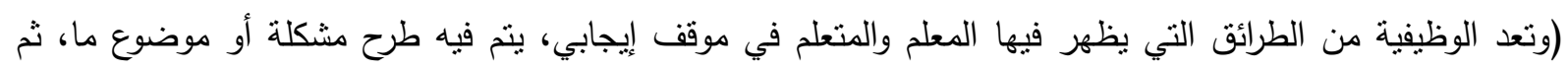

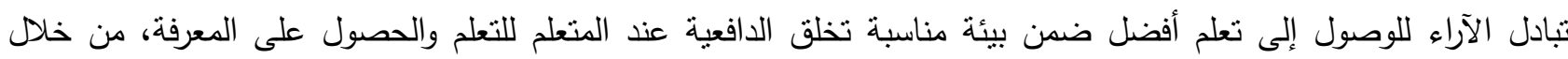

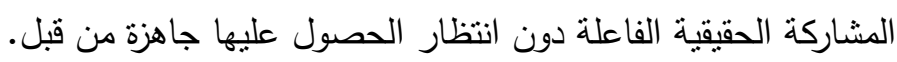
عند البحث وجدت كثثرا من الأسباب التي منعت العملية التعيلمية للغة العربية أن تحقق الأهداف والغايات المحددة لها كمزاولة عملية تعليم اللغة العربية في مؤسسات التعليم الأوزبكي وفق مناهج قديمة لافائدة منها، وعدم استخدام الكفاية التواصلية

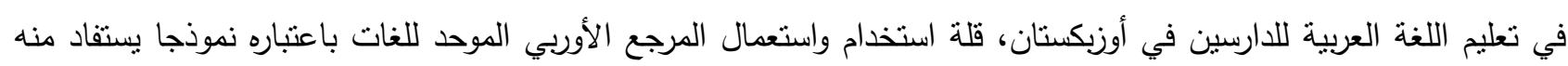

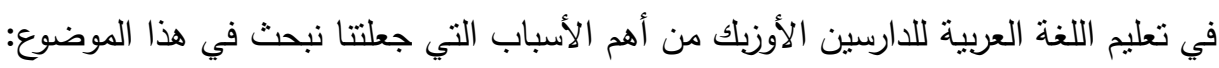
1. الإحساس بعدم كفاية تعليمية اللغة العربية.

2. مزاحمة اللغات الآخرى للغة العربية عند تعليمها ؛ حيث أن اللغات الآخرى نوافرت لها كل الإمكانات المعاصرة في

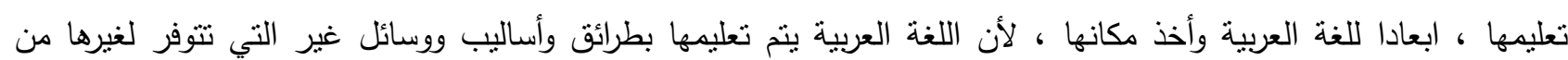


3. اللغة العرية هي إحدى اللغات الرسمية العالمية في الأمم المتحدة ، ولغة تواصل عالمية يضمن لها مكانة عالمية، فمن

$$
\text { الضروي توفير كل ما من شأنه أن يحقق لها ذللك، بكل الطرق والوسائل. }
$$

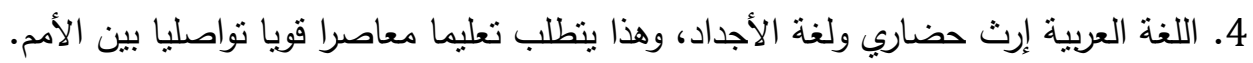

$$
\text { 5. الإقبال الكبير على تعلم اللغة العربية من قبل الناطقين بغيرها في أوزبكستان. }
$$

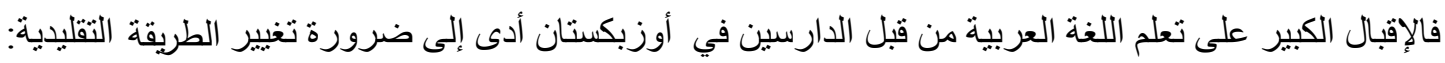

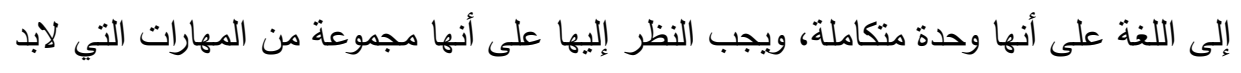

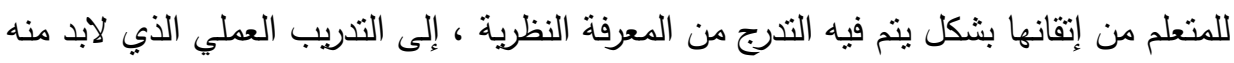

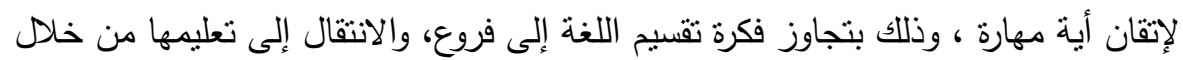

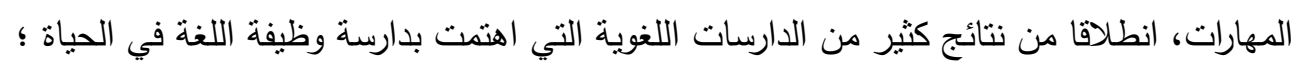

وأثنارت إلى أن الاتصال هو الوظيفة الأساسية للغة، و أن طريقة التدريس لها دور كبير في نجاح التهات

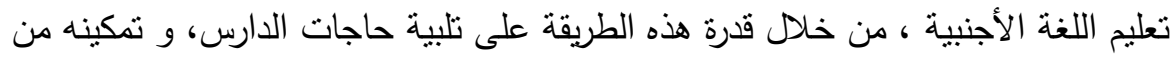

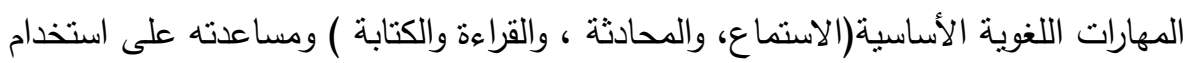

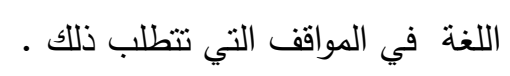

توجد الكثير من الدارسات التي دعت إلى معرفة الحاجات اللغوية للمتعلم، والكثف عن الاتجاهات اللغوية والنفسية التي

تؤثر في تعليم اللغة، وأكدت على أهمية طريقة التدريس في تحقيق تعلم وظيفي فاعل ومؤثر ، وتتمية الكفاية اللغويةالتواصلية عند

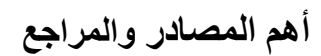

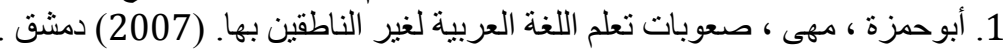

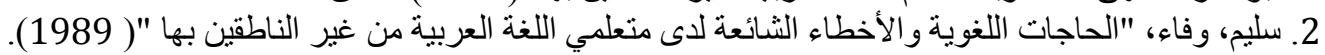

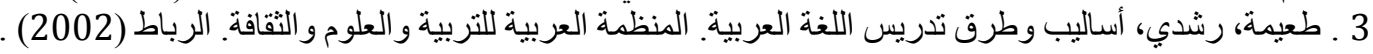

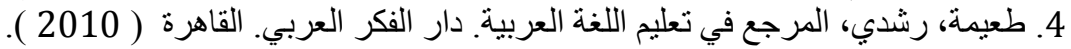

5. عمار ، اتجاهات حديثة في تدريس اللغة العربية. مؤسسة الرسالة. لبنان. (2017)

\section{APPRENTISSAGE DES LANGUES ETRANGERES EN OUZBEKISTAN : OBSERVATIONS PONCTUELLES}

\section{Lucie Lavoisier \\ Professeur de l'Institut des langues étrangèrtes de Samarcande}

Je n'ai qu'une expérience très courte et dans un contexte extrêmement particulier des conditions d'apprentissage des langues étrangères en Ouzbékistan.

Les observations que je ferai dans cet écrit ne sont donc pas à prendre au pied de la lettre, et ne constituent en rien un postulat définitif. En effet, nous n'avons eu, au cours du deuxième semestre de l'année 2019-2020, que 5 à 6 semaines de présence en cours dans les locaux de l'Institut d'Etat des Langues Etrangères de Samarcande avant que le confinement ne soit requis en raison de la pandémie mondiale de coronavirus.

Ce que j'ai pu cependant remarquer au fil de ces premières semaines, c'est avant tout le niveau de compétence élevé de certain.e.s étudiant.e.s en langue française, surtout chez ceux et celles qui combinent les études à l'institut avec une activité professionnelle en relation avec des francophones, en l'occurrence les guides touristiques.

Il va sans dire que l'apprentissage d'une langue va s'approfondir et se perfectionner beaucoup plus facilement chez le locuteur qui en fait un usage régulier et motivé par un 
intérêt, ici professionnel. Ainsi, à l'inverse, d'autres apprenant.e.s du parcours de licence en langue, philologie et culture françaises ne poursuivent pas le même objectif et font montre d'une compétence beaucoup plus faible en interaction. Il me semble que ce constat est toujours valide dans les contextes d'apprentissage "captif», où que se trouve le public concerné.

$\mathrm{Au}$ niveau du contexte d'apprentissage, comme dans tout établissement d'enseignement, les équipements technologiques sont variables d'une salle à l'autre: l'enseignant.e devra alors adapter son programme et ses activités, improviser selon les équipements dont il ou elle disposera au moment du cours. Je pense en particulier aux changements de salle de dernière minute, où la salle finalement assignée ne dispose pas d'équipements audio-visuels, alors que le cours initialement prévu avait une vidéo pour document déclencheur. On peut constater ici une inégalité marquante entre les équipements des salles de chinois, coréen ou anglais, et celles de français ou d'arabe.

En ce qui concerne les relations internationales, j'ai pu remarquer que le réseau francophone ouzbek est bien construit et solidarisé : à l'occasion de la situation exceptionnelle de confinement et d'arrêt des cours en présentiel à laquelle nous avons été confronté.e.s, les établissements d'enseignement francophone, écoles, lycées ou départements d'université, en relation avec la représentation française à l'étranger, l'Alliance française et la coopération universitaire, ont rapidement mis en place, sur les réseaux sociaux, des groupes de partage de ressources didactiques. Un avantage, à mon avis, pour consolider l'esprit d'entraide et de cohésion promu par les institutions de la francophonie. De plus, ce partage spontané et volontaire de ressources s'est surtout concentré sur un aspect ludique et culturel de l'utilisation de la langue, ce qui m'apparaît comme une initiative très motivante pour les apprentant.e.s comme pour les enseignant.e.s : ont été ainsi partagés sur les réseaux des liens pour regarder des films en français, des chansons, des jeux, des concours. Tout ceci a, je l'espère, contribué à maintenir à niveau la motivation de tous ces acteurs de la francophonie, que ce soit dans leur apprentissage ou leur pratique professionnelle, puisque ceux-ci ont été amputés de leur vivacité avec l'arrêt brutal des relations sociales. D'ordinaire, de nombreux concours étaient déjà organisés autour de la langue, dont un de théâtre et une dictée nationale.

A ce propos, il est peut-être utile de souligner que les exigences au niveau de l'acquisition de la langue française sont très fortes (le niveau de difficulté du texte de dictée par exemple), et contribuent ainsi, à mon avis, à garder au français son image élitiste. Est-ce une stratégie pour se démarquer des autres langues dans son parcours (Et en plus, je parle français ! comme atout dans la carrière, mais réservé aux élites) ? Sans nul doute.

Je me demande toutefois si ce niveau d'exigence ne risque pas de décourager celles et ceux qui sont plus timides dans leur pratique de la langue.

Ainsi, j'ai pu remarquer que tous les étudiants ne sont pas investis au même niveau dans la pratique de classe : ce sont souvent les mêmes qui participent, et il devient difficile au fil du temps d'homogénéiser le groupe-classe, la parole revenant souvent aux plus «fort.e.s » en français. Cette disparité provient à la fois de l'investissement personnel des étudiant.e.s puisque notre public est au niveau universitaire donc adulte, mais aussi du rôle de répartition de la parole dans le groupe, qui revient au professeur. Cela dit, une proportion importante des étudiant.e.s à qui j'ai eu affaire montrait une forte motivation, était présente en classe et tentait de s'investir. Ce qui, sur ce point, semble surprenant, c'est qu'on puisse retrouver de grandes différences de maîtrise de la langue chez les 3 ème, 4 ème années de licence ainsi que chez les étudiant.e.s de master: le système d'évaluation est-il alors valide, si deux apprenant.e.s de la même classe peuvent parler et écrire en français au niveau A2 pour l'un, B2 pour l'autre?

Il me sera difficile de trouver une réponse à cette question vu que, à cause de la pandémie, de nouveaux écarts se sont creusés avec l'inégalité d'accès aux moyens numériques 
de communication et diffusion d'informations. Nous avons reçu trop peu d'instructions sur la continuité de l'enseignement et la possibilité d'une évaluation. Il se trouve que la plateforme académique Moodle n'était que très peu en usage jusque là, méconnue des étudiant.e.s qui alors manquaient (et manquent toujours, a priori) de formation à l'utilisation des outils numériques. Il en va de même pour le corps enseignant, habitué à trouver des ressources numériques mais pour les utiliser en classe, non pour les diffuser et les exploiter à distance. On peut toutefois imaginer que cet épisode inattendu et inédit aura contribué à la formation autonome, à la mise en partage d'outils pour la classe, et aura donc eu un effet positif sur l'apprentissage. En ce qui concerne l'accessibilité au numérique, il n'est pas du ressort de l'institut d'assurer le financement du réseau internet dans le pays. Pendant ce temps-là, en Ouzbékistan comme dans de nombreux pays du monde, la continuité de l'enseignementapprentissage n'a pas été la même pour tou.te.s, ce qui est pour le moins regrettable.

Comme je ne connais pas bien le fonctionnement de l'institution scolaire et académique de l'Ouzbékistan, il m'est impossible de porter un jugement définitif ou de prédire le futur, mais d'après ce que mes collègues et étudiant.e.s m'ont rapporté, il s'agit d'un système institutionnel en mouvement, en pleine évolution, qui développe de plus en plus d'opportunités pour son public, tant sur les relations internationales que sur l'adaptation au numérique. Je ne peux alors que saluer les efforts de chacun.e pour animer et développer la grande famille francophone.

\section{THE IMPORTANCE OF DEVELOPING OF SOCIOCULTURAL COMPETENCE OF STUDENTS IN THE PROCESS OF TEACHING FOREIGN LANGUAGES}

\section{Djuraeva Gavhar Normuratovna \\ Lecturer at "Silk Road" International University of Tourism E-mail : djurayevagavhar@gmail.com}

Annotation: This article contains information that considers the concept of socio-cultural competence as the acquisition of English through language multicultural education, which is indispensable without getting closely familiar with the culture of the country of studying and the mentality of the people converse in this particular language, using a foreign language as a transmission of the culture, traditions and regulations of the country of study.

The author separates and discusses the components of socio-cultural and communicative competence, skipping through the prism of historical and social transformations in the country of study and the relationship of different cultures to these modifications. By specifying, refining and characterizing these components, education of students in the application of these competences in various situations, with the aim of achieving mutual understanding in a multicultural society through acceptance and empathy, and learning language to ensure success in intercultural interaction is examined.
Key words :

Sociocultural

competence,

stereotypes, toleration, empathy,

communicative experience, intercultural communicative competence, traditions, sociolinguistic competence, pragmatic competence

Introduction. It is known from ancient times that teaching foreign languages cannot be complete and comprehensive without reference to culture of the country. Since the end of the 19th century, familiarization with the realities (subjects and phenomena inherent to a certain layer of culture) within the framework of teaching process has been an inseparable part of teaching foreign languages. The combination of language learning with studying the culture of the country creates an invaluable motivation for students to learn and also allows to solve all 4 problems of modern learning. Students know about the culture, history and traditions of a certain country using language tools in the process of communication at lessons [Salanovich, 
pp. 18-20]. In addition, the formation of a positive attitude of students to the culture of people who speak a language and to the language itself becomes one of the goals of teaching foreign languages. The obligatory minimum content of educational programs now includes sociocultural knowledge and skills, i. e. information about the country of the language being studied, national values and cultural traditions, peculiarities of national mentality. Thus, socio-cultural competence is of great importance in modern education. This type of competence helps to overcome stereotypes, as well as to develop tolerance towards representatives of other languages and other cultures. At foreign language lessons, sociocultural competence is formed by introducing students to national and cultural specifics of speech behavior and realities of countries: customs, rules, norms, rituals, social stereotypes, country knowledge. Sociocultural competence is a complex phenomenon and consists of linguistic and country studies, sociolinguistic, socio-psychological and cultural components. Formation of socio-cultural competence should be started from the very beginning. This may include texts focused on conversational speech in all its main spheres, detailing the most common everyday situations; carefully selected examples, revealing the basic values and concepts of culture of the studied language, as well as including examples of correct and incorrect use of vocabulary, phraseology and grammar of a given language. Sociocultural competence presupposes that language can be a means of transmission of cultural experience of the country, a reflection of historical changes, as well as knowledge of norms of speech behavior depending on the communicative situation; implies the ability to detect nationallabeled vocabulary in texts of different styles and understand their meaning.

\section{Results and discussion}

Sociocultural competence is a set of knowledge about the country of the studied language, national and cultural peculiarities of social and speech behavior of native speakers and the ability to use such knowledge in the process of communication, following the customs, rules of conduct, etiquette norms, social conditions and stereotypes of behavior of native speakers. Sociocultural competence is a component and part of the communicative competence.

The content of the socio-cultural competence can be represented in the form of four components:

1) socio-cultural knowledge;

2) communication experience (style of communication, adequate interpretation of foreign-language culture phenomena);

3) personal attitude to foreign-language culture facts;

4) mastery of language application methods (adequate use of nationally labeled vocabulary in speech in different spheres of intercultural communication).

It goes without saying that historical changes in a country, cultural peculiarities, differences in traditions and customs usually turn out to be a stumbling block in communication of people of different nationalities. The particular difficulty lies not only in difference of some realities, but in the attitude of representatives of different cultures to them, as these subjects and phenomena live and develop in different worlds. Behind language and cultural equivalence lies the conceptual equivalence, the equivalence of cultural perceptions. The view that knowledge of the specifics of the country in which the language is being studied is very important has led to a reflection on the linguistic and cultural approach to English language learning. The fact is that the country information presented at lessons activates cognitive interest of students, favourably influences the development of their communication skills, motivates them to further study of the language and allows solving a number of educational tasks.

Let us pay attention to features of communicative competence and socio-cultural competence and their interaction.

The components of communicative competence can be described as: 
1) linguistic (or linguistic) competence, involving knowledge about language, knowledge, skills and abilities to understand and produce foreign-language statements to implement the speech and non-speech communication with carriers of the studied foreign language, as well as "ownership of the system information about the target language" [Asimov, Shchukin 2010, p. 123]. This competence includes lexical, grammatical, semantic, phonological, spelling and orthoepic competence, which presupposes knowledge of the system of the studied language and skills of operating language communication tools;

2) sociolinguistic competence, which includes knowledge of language norms and rules of communication, speech and non-speech etiquette and includes "knowledge and skills necessary for effective use of language in a social context" [Asimov, Shchukin 2010, p. 288], which presupposes the ability to understand and generate foreign language statements (different types of discourses), combine them in a single act of communication in accordance with the specific situation of communication, speech task and communicative intent (Federal state educational standard);

3) pragmatic competence, which is a set of knowledge, rules for constructing statements, their Association in the text (discourse), the ability to use statements for various communicative functions, the ability to build statements in a foreign language in accordance with the "peculiarities of interaction of communicants" [Asimov, Shchukin 2010, p. 228];

4) socio-cultural competence, which is knowing the socio-cultural specificity of the country of the target language and "skills and abilities, allowing to carry out speech and non-speech communication with native speakers in accordance with the specific rules governing verbal interaction in a particular linguaitaliana community»;

5) strategic competence, which shows the ability to use their own speech foreign language experience to compensate for gaps in knowledge of the language [pan-European competence of foreign language: Study, training, evaluation. 2005].

Thus, in a number of fundamental studies (I. A. Zimnaya, S. V. Mureeva, T. V. Parfenova, I. L. Pluzhnik, M. N. Razdobarova, T. A. Tkachenko, etc.), the concept of "socio-cultural competence" is considered as a component of communicative competence.

Communicative competence, which functions in the process of communicating with foreign-language interlocutors as an intercultural communicative competence. Intercultural communication competence, in turn, has been defined and interpreted in research by scientists.

As shown by the study of this aspect of the problem, a number of authors give a definition and interpretation in the research of scientists.

As shown by the study of this aspect of the problem, a number of authors define the concept of "intercultural communicative competence" as the ability of a person to exist in a multicultural society [Galskova, GEZ 2006; Plekhanova 2007], to reach mutual understanding with representatives of other cultures [Safonova 1991, 1996; Asimov, Shchukin 2009, p. 134], the ability and desire to achieve understanding in intercultural contacts by verbal and nonverbal means of communication [Irishanova 2007, p. 22], as well as "adequately assess the communicative situation, effectively use verbal and nonverbal means, put into practice communicative intentions and check the results of communication using feedback "[Sadokhin 2009, p. 23].

Analysis of interpretations of the concept of " adequately assess the communicative situation, effectively use verbal and nonverbal means, put into practice communicative intentions and check the results of communication using feedback "[Sadokhin 2009, p. 23].

The analysis of interpretations of the concept of "intercultural communicative competence" allowed us to make the following generalization regarding the significant components of this competence. These components are:

1) substantive, which is understood as a certain amount of knowledge about the culture of the country/countries of the target language (in particular, national and cultural 
concepts, rules of speech and non-speech behavior, etc.) and also about the areas, topics and situations in which they operate knowledge (T. A. Pavlicek, V. P. Furmanova, etc.);

2) active component, podrazumevayut "possession of skills to follow the norms of inoculum" [Pavlicek 2007, p. 20], comparing them with the norms of their culture, ability to acquire essential for the study of culture knowledge and to use the knowledge [of Plekhanov 2007], the ability to compare phenomena of a different culture, a different lifestyle, to find a common and differences when comparing different cultures, the desire to expand their knowledge about the culture and specifics of the country studied language, etc.;

3) cognitive, which "are a synthesis of knowledge about the native culture of the country of the target language, and General knowledge of culture and communication" [Halskov, guez, 2005, p. 73-74], knowledge of the conditions and effort needed for effective intercultural communication; according to some scholars (N. D.Galikova, N. And.GEZ, N. G.Murav'eva, M. V. Plekhanova, V. V. Safonova, etc.), the cognitive component can be considered as socio-cultural competence;

4) strategic-this component includes "verbal, educational and research strategies of the student" [Galskova, GEZ 2005, p. 73-74], the desire to achieve mutual understanding in intercultural communication, the use of verbal and non-verbal means to compensate for gaps in knowledge and skills;

5) affective, which includes tolerance and empathy-the ability to understand the position of another person, take into account the socio-cultural specifics of the communication partner when choosing verbal and non-verbal means of communication, take into account differences in the description and perception of the world by representatives of different cultures, recognize the value orientations of nonnative and own culture [Elizarova 2001, p. 218].

Thus, as shown by the review of the components of intercultural communicative competence, we can say that the socio-cultural competence we are interested in is part of each of the above components of intercultural communicative competence in the form of certain knowledge, skills and abilities.

The condition and product of the functioning of intercultural communication competence is effective intercultural communication, in order to achieve the goals of which the communicant uses knowledge of cultural facts, rules and categories that ensure the success of intercultural interaction. It is also pointed out that the presence of a person's intercultural communicative competence "allows in the process of intercultural communication to choose the necessary speech and language means in accordance with the socio-cultural context, to create a discourse using socio-cultural means, to choose strategies and tactics of communication to achieve the set goals, which increases the effectiveness of intercultural interaction" [Narolina 2010, p.4].

Thus, the goal of forming an intercultural communicative competence is to achieve such a quality of a language personality that will allow it to go beyond its own culture and become a mediator of cultures without losing its own cultural identity [Elizarova 2001].

It should be noted that the content of the concept of "socio-cultural competence "(as part of the intercultural communicative competence) reflects the goal of developing the student's personality, forming his ability and willingness to participate in the dialogue of cultures based on the principles of cooperation, mutual respect, tolerance for cultural differences and overcoming cultural barriers. This value of sociocultural competence is also emphasized by psychologists (B. V. Belyaev, L. S. Vygotsky, T. G. Egorov, I. A. Zimnaya, etc.), who note that the presence in the mind of each participant of communication of their personal baggage, in other words - their own culture (individual worldview), one way or another opposed to him another's world (someone else's image of consciousness) creates a Dialogic personality. It is the Dialogic nature of the individual that makes it capable of the dialogue of cultures as a result. In the process of exposure to foreign culture in the context of dialogue of 
cultures of the future specialist is based on the cognitive tools of their culture, privlechenie to realize the means of foreign culture, new knowledge about her, shaped her knowledge, and new knowledge about their culture, created with the knowledge of foreign culture [Khaleeva 1989].

Accordingly, when participating in intercultural communication, the communicant must, in order to successfully interact with a foreign-language interlocutor, adequately accept another culture, without losing their own cultural identity, while having their own experience and socio-cultural baggage, as well as being a carrier of their own cultural traditions (N. D. Galskova, N. I. GEZ, G. V. Elizarova, etc.). In this regard, the important role of socio-cultural competence

becomes obvious.

Russian methodological science is associated with the works of van Dyck and the Council of Europe on cultural cooperation, according to which this concept is one of the components of communicative competence and is defined as "the ability to adequately interact in everyday life situations, establish and maintain social contacts using a foreign language" [Muraveva 2009, p.140]. Modern researchers (G. A. Vorobyov, G. V. Elizarova, etc.) give this concept the following similar definitions: socio-cultural competence is a community of knowledge, skills and abilities, including certain abilities and qualities formed in the process of intercultural communication; this

is "a set of knowledge about the country of the language being studied, national and cultural features of social and speech behavior of native speakers and the ability to use such knowledge in the process of communication, following the customs, rules of behavior, etiquette, social conditions and behavior stereotypes of native speakers" [Asimov, Shchukin 2010, p. 286].

The authors mentioned above note the following components of intercultural communicative competence:

- General cultural (awareness of General cultural knowledge and value systems that exist in different countries);

- socio-cultural (knowledge of interpersonal verbal communication skills with representatives of another country, compliance with the corresponding ethical and etiquette speech norms);

- linguo-sociocultural, presupposing knowledge of lexical and grammatical units inherent in the language of different countries, their correct use in the communication process [Razdobarova 2008].

The above allows us to consider the socio-cultural competence as an integral system that includes a number of components, has its own organization and has the integrative properties of the whole, not reduced to the properties of individual parts.

Thus, it can be argued that all the competencies discussed above (communicative, intercultural communication) include, as proved by a number of authoritative researchers, a number of specific components. Among these components, each of these types of competencies includes a socio-cultural competence, which, in turn, includes certain components/components. At the same time, the register of data is made up of components and their number is different for different scientists. At the same time, all researchers identify as the main components:

- socio-cultural knowledge (encyclopedic, background, etc.), reflected in a particular language material, and how to use them (depending on the scope, situation, and topic of communication);

- communication experience and personal relationships of communicants [Asimov, Shchukin 2010 p. 287].

Consideration of the above-mentioned components that make up the sociocultural competence allowed us to detail, clarify and characterize these components. In order to solve 
the main problem of the dissertation, we were guided by the opinion of many researchers who established these characteristics and define these characteristics as competencies (I. L. BIM, M. A. Bogatyreva, E. M. Vereshchagin, G. V. Vorobyov, N. D. Galskova, G. V. Yelizarov, N. A. Ignatenko, V. G. Kostomarov, N. G. Muraviev, V. V. Safonov, V. P. Sysoev, G. D. Tomakhin, etc.). These components are the following:

- language features of social strata, representatives of different generations, genders, social groups, dialects: speech stereotypes, situational cliches, communicative cliches, formulas of speech etiquette, models of speech behavior (information of a sociolinguistic nature);

- socio-cultural, historical, cultural, ethno-cultural background, knowledge of the traditions and customs of the people of the language being studied, information about the national character, about the main values and typical for members of this society, about the norms of behavior (information of a cultural nature);

Lexical units with socio-cultural semantics (linguoculturems) and the ability to apply them in situations of intercultural communication; non-equivalent words, background vocabulary, realities (information of a linguistic and cultural nature).

Conclusion. The information presented in this section concerning the content /components/components of the socio-cultural competence as part of the intercultural communicative competence allows us to make the following generalizations that reflect different points of view on the concept of "socio-cultural competence".

1) socio-Cultural competence is a whole, in which socio-cultural knowledge is interconnected, formed by the appropriate language material and functioning in the process of personal communication of communicants who have a certain experience of this communication.

2) socio-Cultural competence is the relationship and interdependence of such components as strategic, activity, cognitive, content, and affective.

3) socio-Cultural competence includes sociolinguistic, cultural and linguistic country competence in its structure.

The communicative function of language is indispensable part of intercultural communication, but sometimes communication participants are unable to understand each other, despite the fact that they use the same language structures. This is because the language tools chosen by the speakers are based on different socio-cultural structures. Pochinok T.V. suggested that achieving mutual understanding in intercultural communication can be achieved by creating a common communicative and pragmatic space [Pochinok, pp. 3740]. One of the key points of sociocultural competence is the readiness to compare countries and their historical development, cultural level and features of people living in a particular territory. It is also very important to explain to students how important it is to respect other cultures, customs, foundations and to show tolerance to representatives of any nation.

Thus, the formation of socio-cultural competence makes it possible to realize all four goals of modern education:

1) cognitive - the learner represents the world as an integral multilevel system;

2) educational - the learner has such personal values as humanistic worldview, patriotism, respect for other cultures, morality, culture of communication;

3) practical - the student has a command of foreign language communication in the unity of all its competences (language, speech, educational and cognitive);

4) developing - the student has formed socio-cultural stereotypes of behavior, as well as enriched personal mental experience.

Thus, as a result of consideration of this issue it should be noted once again that the formation of socio-cultural competence at foreign language lessons is difficult to overestimate. Considering the fact that socio-cultural competence is a component of a foreign-language communicative competence, the formation of socio-cultural knowledge and skills is one of the 
goals of education, we can safely state that studying foreign languages without getting acquainted with the culture and mentality of the country cannot be comprehensive.

\section{Literature:}

1. Azimov E. G, Shchukin A. N. New dictionary of methodological terms and concepts (theory and practice of teaching languages): scientific and methodological publication.- Moscow:Icarus, 2010.-448c 2. Iriskhanova K. M. Intercultural communicative competence and the educational and methodical complex for universities of non-linguistic specialties./ Vestnik ser "Lingvodidaktika" - Moscow: MGLU "Rema", 2007. - Vol.538. - Pp. 2232.

3. Sadokhin A. P. Intercultural competence: the essence and mechanisms of formation: author's review. ... dis. Dr. of Culturology: 24.00.01 .- Moscow, 2009.- 44C

4. Halskov N. D, GEZ N. And. Tero foreign language teaching: Didactics and methodology of teaching.pic for students.LINV.UN-tov and FAK.yin.yaz.higher.PED.studies'. institutions. -M.: ACЛOEM1A, 2005. $336 c$.

5. Elizarova G. V. Culturological linguistics: the experience of studying the concept for methodological purposes. -SPb.:Belvedere, 2000-140c.

6. Pochinok, T.V. Formation of the sociocultural competence as the basis of the intercultural communication // Foreign languages at school. - 2007. - - № 7. - - C. 37-40.

7. Salanovich, N.A. Learning to read the authentic texts of the linguistic and foreign languages content. - 1999. - № 1. - C. 18-20.

\section{E-LEARNING IN THE ENGLISH LANGUAGE EDUCATION}

\section{Giyasova Umida Erkinovna Scientific researcher, Head scientific and methodological center E-mail: umidagiyasova@rambler.ru}

Annotation: The definition of "E-learning" is given, the possibilities of using e-learning methods in the learning process of education institution are considered.
Key words : E-learning, online learning, electronic services, computer learning.

The specifics of an English language course determine the active use of a computer in the classroom. Different definitions can be found for the" e-learning". Victoria L. Tinio, for example, states that" e-learning" includes learning at all levels, formal and informal, which uses a computer network (intranet and extranet) for the delivery of teaching materials, interaction, and/or facilitation. For most of the process of learning that takes place with the help of the Internet is often referred to as online learning. Broader definition is considered the e-learning is learning through electronic services. Although a variety of definitions but basically agreed that the e-learning is learning by using electronic technology as a means of presenting and distributing information [2].

The word e-learning is used as a synonym for virtual knowledge, online learning, computer learning, network knowledge and network learning. The purpose of e-learning is to motivate learners to absorb personal accomplishment or to get a degree certificate without actually attending any education institution. Another idea is to use e-learning at all levels of instruction so that learners understand the lessons correctly.

The advantages of using computer training programs are: reducing the number of grammar exercises in the lesson in favor of communicative tasks; the possibility of independent and unlimited repetition of exercises and rules, taking into account individual abilities; student errors are corrected immediately, thereby reducing the risk of fixing wrong skills; student motivation is enhanced through the use of modern methods and tools (computer, video projector, Internet); consistent feedback allows you to really assess the level 
of knowledge of students and purposefully prepare for the exam. For foreign language learners, the Internet offers, in addition to authentic web-sites, sites designed specifically for foreigners that contain recommendations for learning the language, lists of useful links, and thematic collections of exercises [1]. Some multimedia tutorials and encyclopedias regularly update their data via the Internet.

Despite all the advantages, e-learning does not have to become regular in a foreign language lesson or even replace classes in the classroom, since no electronic system can measure and evaluate creativity in creating text or dialogue. Pronunciation training, improvement of oral skills, development of communicative and social competence should be purposefully carried out in class. Computerization of a foreign language teaching helps facilitate access to information and reduce the time required to learn a language. Currently, there is a huge selection of multimedia products, Internet sites containing the information necessary for learning a foreign language, electronic textbooks, databases with thematic texts and exercises.

New information and communication technologies provide English language learners with the opportunity to use multimedia training and reference programs, as well as numerous language materials. The use of modern computer technologies makes sense and benefits only if you use them consciously. The skills of working with multimedia programs and the Internet are often referred to as the ability to use a computer, i.e. purely technical aspects. However, much more important is the trainer's competence in didactics, awareness of the development of multimedia products, and the ability to assess the feasibility of using a particular product based on the needs and capabilities of trainees.

\section{References:}

1. Айналиева А.Р. Использование мультимедийных средств на занятиях по иностранному языку в вузе / А.Р. Айналиева // Вестник КРАУНЦ. Гуманитарные науки. - 2009. - № 9. - С. 74-75.

2. Victoria L. Tinio, Modificating teaching through ICT. The American journal, 12. 1999. - Pp.56-63.

\section{ЧЕТ ТИЛИНИ ЎКТИШДА \\ ВИДЕОФИЛЬМЛАРДАН ФОЙДАЛАНИШ МАҚСАДЛАРИ}

\section{Ибрагимова 3., Абдуллаева Г. Урганч Давлат Университети катта ўқитувчилари E-mail: gulnora2003@mail.ru}

Annotation: The article provide information about how to improve students' listening and speaking skills in German language by the help of watching movies. The purpose of teaching foreign language is considered differently by the representatives of various methods. According to the communicative method the target of linguistics is to acquire practically, moreover it is obligated to develop countrystudy, the relationships among cultures, mental skill and emotion.
Key words : mental skill, relationships among the cultures, target of language, comprehension, discussion, separately, manuals, Soap operas, characterization crucial

Чет тилини ўқитиш мақсадлари турли метод вакиллари томонидан турлича белгиланган. Коммуникатив методга кўра тил таълимининг мақсади тилни амалий эгаллаш билан баробар бадиий, мамлакатшунослик, маданиятлараро мулоқот хамда ақлий қобилият ва хиссиётни ривожлантириш каби ечимлардан иборат бўлиши лозим. 
Европада кенг тарқалган методик адабиётларда олмон тили таълимидан қуйидаги мақсадлар кўзда тутилади:

1) Лисоний мақсадлар

2) Кўникма ва малакаларни ривожлантириш

3) Муомала қобилиятини ривожлантириш

Жумладан, видеолар билан ишлаш қуйидаги имкониятларни яратади:

- ўқувчиларда мотивация уйғотади, мавзуга бўлган қизиқишини орттиради;

- ўқувчиларнинг мавзуга оид билимларини фаоллаштиради;

- ўқувчиларнинг эътиборини мавзуга жамлайди;

- мавзуга оид мухим сўзлар эсга туширилади, йиғилади ва фаоллаштирилади;

- мавзуга оид видеони кўришга доир тайёргарлик кўрилади.

Видеони кўришдан олдинги машқларни бажариш жараёнида расмлар катта ахамиятга эга. Уларнинг хизмати қуйидагиларда ўз ифодасини топади:

- видеода тасвирланган вазиятни яққоллаштириш;

- мухим тушунча ва нутқ воситаларини тасаввур қилиш, тайёрлаш олиндан ишлаш;

- ўқувчилавр мотивациясини ошириш;

- ўқувчиларни кўриш ва тинглашга тайёрлаш.

Кўришдан олдин бажариладиган машқларга қуйидагиларни намуна қилиб кўрсатиш мумкин:

1) Расмлар ва уларга қўйиладиган саволлар (W-Fragen)

- Wen sehen wir auf diesem Bild?

- Wo spielt die Szene?

- Was machen die Personen im Hintergrund?

- Worüber sprechen sie?

2) Ассоциограмм

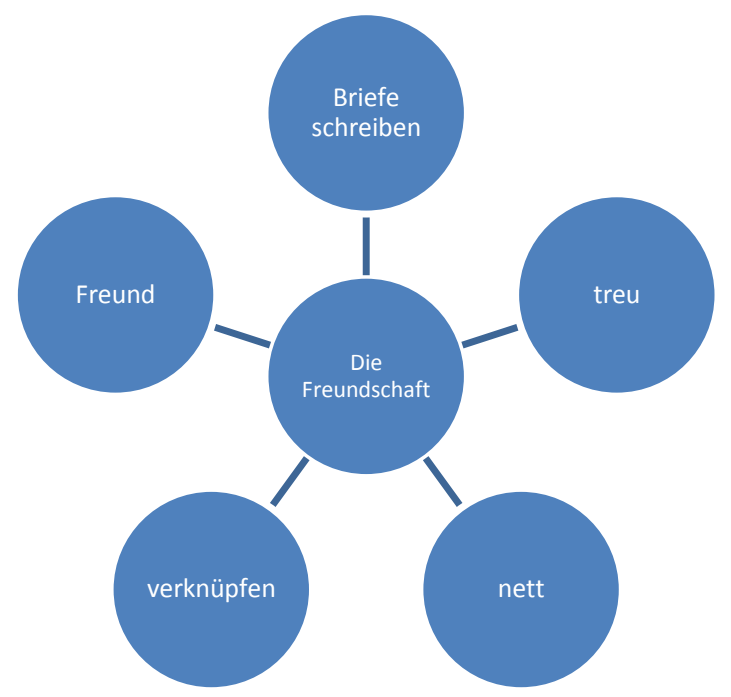

3)Расмли карточкалар

Иккинчи босқичда фильм олдин сўзсиз, овозсиз кўрсатилади ва қуйидаги топшириқлар берилади: фильм парчаларга бўлиб кўрсатилади.

- Фильм нима хақида?

- Бош қахрамонлар ким?

- Воқеа қаерда, қачон, қай вазиятда содир бўлган?

Бу жараёнда ўқувчи эркин муомалага тайёрланади. 
Кейинги босқичда фильм овозли кўрсатилади. Фильмни кўриш билан баравар тинглаш ўқувчида вазиятни тўғри тушунишга ёрдам беради. Фильмни кўрган турган вақтда қуйидаги топшириқларни бажариш мумкин:

- Ja / Nein

- Richtig / falsch

- Wer hat was gesagt?

Тўртинчи босқичда фильм қисмларга бўлиб кўрилади. Ишнинг бундай усули ўқувчиларнинг тушунмай қолишдан қўрқишларини бартараф қилиш ва уларнинг фикрларини бир нуқтага тўплай олиш имкониятларини кенгайтиради. Ўқитувчи бу ўринда ўқувчиларга кўмакчи вазифасини ўтайди. Шуни айтиш керакки, фақат тушуниш эмас, балки фараз қилиш хам қисмларга бўлинган холда амалга оширилади.

Замонавий дарсликлар, ўқув қўлланмалар таркибида видеофильмлар ёзилган CD лар хам киради (Sicher B1, В2 каби хорижий адабиётлар). Фильмлар турли йўналишларда, масалан, мультфильм, хужжатли фильм, сериал, бадиий фильм кабилар бўлиши мумкин. Улар таълим жараёни учун катта ахамиятга эга. Фильмни исталган жойида тўхтатиб қайта эшитиш, исталганча қайта эшитиш ўқувчиларнинг тушунганликларини текшириб кўриш, хар бир қайта тинглаш жараёнида топшириқни ўзгантириш ва бошқа бир қатор амалларни бажариш мумкин. Тинглашдан кейин бўладиган топшириқлар қуйидагича бўлиши мақсадга мувофиқ:

1) Фильмнинг давомини гапириш

2) Бош қахрамон образига сўровномани тўлдириш

3) Фильм сизда қандай таассурот қолдирди ва нима учун?

4) Бош қахрамонларга қайси сифатлар мос келади?

$\begin{array}{ll}\square \text { sympatisch } & \text { unsympatisch } \\ \square \text { typisch } & \text { rechthabemisch } \\ \square \text { ehrgeizig } & \text { langweilig } \\ \square \text { frech } & \text { ganz normal } \\ \square \text { unordentlich } & \text { rebellisch } \\ \square \text { intelligent } & \text { neigierig }\end{array}$

5) Фильмни бахолаш сўровномаси

6) Фильмни танқид қилиш сўровномаси

Бадиий фильмлар билан ишлашнинг мураккаблиги унинг узоқ вақт давом этишидир. Улар одатда 90 ёки 130 дақиқа давом этади. Олдин ўқувчиларга фильм тўлалигича кўрсатилади. Бадиий фильмлар тили ўрганилаётган мамлакатнинг тарихи, маданияти, санъати хақида хаётий лавхалар орқали тўқима образлар бўлса хам ажойиб тарзда хикоя қилади ва ўқувчининг қизиқишини орттиради. Шуни айтиш жоизки, тил билиш даражаси ва ўқиш мақсадига қараб фильмни қисмларга бўлиб кўрсатиш ва шунга асосан топшириқ бериш мақсадга мувофиқдир.

Замонавий дарслик деб тан олинган „Sicher“ дарслиги мисолида кўриб чиқмоқчи бўлсак, шуни айтиш лозимки, „Sehen und Hören“ қисмида мультфильм, хужжатли ва бадиий фильмлар тавсия қилинган. Масалан, „Кokowääh“ бадиий фильмини олсак. Талабалалар биринчи босқичда фильм хақида расмга қараб ўз тахминларини баён қиладилар. Ундан кейин фильмни қисмларга бўлиб томоша қиладилар. Фильм олдин овозсиз қўйилади ва талабалар бунга ижодий ёндашиб мавзу нима хақида эканлигини ёнидаги сухбатдоши билан тахмин қиладилар ва гурухга ўз тахминлари хақида гапириб берадилар. Кейинги босқичда кетма-кетлик занжирини тузиш мумкин, яъни харакатлар ва ходисалар кетма-кетлигини.

1. Was bedeutet Kokowääh?

2. Wer ist Magdalena?

3. Henrys Ex-Freundin?.... und so weiter 
Ўқувчиларга ўзларининг яхши кўрган немисча фильми хақида тайёрланиб келишлари топшириқ сифатида уйга берилади.

Хулоса қилиб шуни айтиш лозимки, бир вақтнинг хам кўриш ва тинглаш ўқувчилар тафаккурини ривожлантиради, уларни ижодий фикрлашга ўргатади, мантиқий тафаккурин ўстиради, хотирани мустахкамлайди, ўқувчида мустақил ишлаш малакасини ривожлантиради. Хуллас, ўқувчининг ақлий, хиссий ва ички интилиш жихатларини ривожлантириш орқали унинг хис-туйғуларини камол топтириш ва фаоллик даражасини кучайтиришда видеофильмлар ижобий таъсир кўрсатади. Ва бу борада мактабгача таълим муассасалари, умумтаълим мактаблари ва олий таълим муассасалари ўртасида чет тилларини ўқитишнинг ўзаро узвийлиги таъминланса янада мақсадга мувофиқ бўларди.

\section{Фойдаланилган адабиётлар:}

1. Böschel Claudia, Sicher B2. Hueber-Verlag, München, 2013

2. Dieder Arnsdorf, Vide im Deutschunterricht. Langenscheidt, München, 1996

3. Michael Schart, Michael Legutke, Lehrkompetenz und Unterrichtsgestaltung. Klett, Stuttgart, 2012

4. S.Saidaliyev, Tllar o'qitish metodikasi va ta'lim texnologiyalari, Namangan, 2019

\section{ЧЕТ ТИЛИНИ ЎРГАНИШДА ЁЗУВ КЎНИКМАСИНИ РИВОЖЛАНТИРИШ.}

\section{Исраилова Дилором Шомахаматовна Ўзбекистон Давлат Жахон Тиллари Университети ўқитувчиси E-mail: dilorom 76@mail.rutel.}

Annotation: This article discusses the formation and development of writing skills in foreign language learning. It was noted that in order to increase the interest in learning a foreign language, it is important that the teacher organizes the lesson methodically correct and rich in didactics. Several ways to develop writing skills and increase interest in it are given as examples.
Key words : Effectiveness of teaching, teacher skills, writing skills, creative thinking, vocabulary, group work, tasks.

Бугунги кунга келиб, техника жадал ривожланаётган бир даврда таълим тизимида хам кўплаб мухим ишлар амалга оширилмоқда. Шу кунга қадар замонавий педагогик технологияларни ўқув жараёнига тадбиқ қилиш усуллари яратилган бўлиб, улардан ўқув жараёнида кенг қўлланилмокда.

Таълим самарадорлигини ошириш орқали ёшларни илмли, мустақил фикрловчи, фаол, эркин, етук инсон қилиб тарбиялаш ва шакллантиришга эришилади. Бундай самарадорликка эришишда таълим тизимида замонавий педогогик технологиялардан ўқув жараёнида фойдаланиш мухим ахамият касб этади. Бу айниқса чет тилларини ўқитишда бугуннинг долзарб масалалардан биридир. Чунки, дарс бериш жараёнининг бир хил қолипда олиб борилиши талабани зериктириб қўймоқда. Ушбу тизимдаги ислохотларнинг муваффақияти эса кўп жихатдан ўқитувчига боғлиқ. Ўқитувчи бу ўринда билимли, атрофлича фикрлай оладиган, дунёқараши кенг, изланувчан, илғор педогогик ва ахборот технологияларини самарали қўллай оладиган, ўз устида тинимсиз ишлайдиган ижодкор шахс бўлиши керак. Анъанавий таълим жараёнида талабаларни тайёр адабиётларни ̆қиб, билимларни эгаллашга ўргатилган бўлса, замонавий педогогик технологиялар уларни эгаллаётган билимларини ўзлари 
қидириб топишларига, мустақил ўрганиб, тахлил қилишларига, хатто хулосаларни хам ўзлари келтириб чиқаришларига ўргатади.

Хозирги глобаллашув даврида таълим олувчиларнинг чет тилларини билмасликларини тасаввур хам қилиб бўлмайди. Чунки юртимизда неча йиллардан бери хорижий тиллар ўрта ва олий таълим тизимининг узлуксиз қисми бўлиб келмоқда. Халқаро муносабатлар авж олган замонамизда бир ёки бир нечта чет тилларни билиш ўзаро муносабатларда коммуникативликни ривожлантириш билан бирга нуфузли иш ўрнига эга бўлиш имкониятини хам яратади.

Чет тилларни мукаммал ўрганиш учун аввало мақсад аниқ бўлиши ва уни ўрганишга кучли хохиш, қизиқиш бўлиши керак. Бизга маълумки, Ўзбекистонда чет тилларини ўрганишга қизиқиш кучайиб боргани сари уни ўқитишда самарали усулларни қўллашга алохида эътибор қаратилмоқда. Тил ўрганишга бўлган қизиқишни оширишда ўқитувчининг чет тили дарсини методик жихатдан тўғри ва дидактикага бой ташкиллаштириши мухим ахамият касб этади. Дарс мобайнида маълум назарий билимларни ўқувчига етказиш, унда айрим фаолият юзасидан кўникма ва малака хосил қилиш, маънавий сифатларни шакллантириш, ўқувчи билимини назорат қилиш хамда бахолаш ўқитувчидан юксак махорат ва тезкорлик талаб қилади Чет тилини ўқитиш жараёнида ўқитувчининг мақсади талабада гапириш, тинглаб тушуниш, ўқиш, ёзиш кўникмаларини хосил қилиб, уларни ривожлантиришдан иборатдир. Бу кўникмаларни хосил қилишда янгича усуллардан, замонавий педогогик технологиялардан фойдаланиш жуда қўл келади. Чет тилини ўрганишда нутқ фаолияти турларидан бири бўлмиш ЁЗУВнинг нима функцияси бор? Умуман олганда нима учун ёзишни ўрганиш керак? деган саволлар туғилади. Уни 2 турга бўлиш мумкин.

1.Йўналтирилган ёзув: олдиндан берилган грамматика ва лексикага оид дидактик машқлар

2.Эркин (ижодий) ёзув: ижодий ёзувда бирор янги нарса пайдо бўлиши , ёки маълум бир нарсага камида бир янгича қараш амалга ошиши керак. Яна шуни исботлаш мумкинки, ижодий ёзув ёзиш кўникмасига юқори даражада ижобий таъсир кўрсатади.

Талабаларда ўрганиш жараёнида эса ёзишга нисбатан ўқиш ёки оғзаки сухбатлашишга хохиш кучлироқ бўлади, бир қолипга солинган лексик ёки грамматик машқларни ёзишдан кўра кўпроқ ижодий фикрлашга ундовчи машқларни бажаришга қизиқиш кузатилади. Бундай холларда йўналтирилган ёзиш (гапларни тўлдириш, комбинация қилиш, ва х.клар)дан кўра эркин, ижодий ёзиш усулларидан фойдаланиш яхши натижа беради. Ёзиш хам мароқли жараён эканлигини кўрсатиш ва бу кўникмани шакллантиришда ўқитувчи етарли билим ва тажрибага эга бўлиш билан бирга изланувчан хамда бироз ижодкор бўлса, у дарс жараёнида қўллаган усуллар талабаларнинг дарсда фаол иштирок этишларига, қизиқиб ишлашларига, билимни яхши ўзлаштириб, ўз имкониятларидан тўлиқ фойдаланишларига, чет тилини ўрганишга бўлган қизиқишларини оширишга эришилади.

Чет тили машғулотларида ижодий ёзувнинг мақсадини умумлаштириб шундай ифодалаш мумкин: у чет тилини ўрганувчига

-ёзишдаги қийинчиликни, ўзидаги тортинчоқликни бартараф этишга;

-бошқаларни тушунишга;

-ўзини тушунишга, хиссиётларини, туйғуларини, фикрларини баён этишга;

-тажриба ва ғояларини, фантазиясини қўзғаб, ўзининг ижодкорлик қирраларини кашф этиш, қобилиятини юзага чиқаришга;

-чет тилига доир ўрганган сўз бойлиги, грамматик билим ва кўникмаларини ўйин тарзида амалда қўллаш ва синаб кўришига ёрдам беради.

Ижодий ёзувдан пайдо бўлган матнни ўқишга, музокара қилишга, фикр билдиришга ва қолганини бошқалар давом эттиришларига тавсия қилиш мумкин. 


\section{Ёзма матн яратишга ўқувчида қандай қилиб қизиқиш уйғотиш мумкин?}

Шу ўринда бир қанча тавсиялар бериш мумкин:

-материал сифатида қизиқарли, ёшга мос келадиган, хиссиётга бой расмлар, фильмлар, куй-қўшиқлар;

-ўқувчини чет тилидаги билим кўникмаларини амалда синашга ундовчи вазифалар; - ўйинларни тавсия этиш;

-ўқувчини бир ўзи ёки гурухда ёзишини танлаш имконини бериш, бу орқали унга ишонч мухитини яратиш ва энг мухими яратилган матнни тақдимотини рад этмаслик керак.

Ижодий ёзиш учун қизиқарли вазифаларни аслиятдаги дарсликлардан олиш ёки улар асосида ўқитувчи хам мустақил ишлаб чиқиши мумкин. Шу ўринда Тошкентдаги Гёте Институти семинарларида кўрсатилган ва дарсларимда қўллаб ўрганган методлардан айримларини мисол келтирмоқчиман. Масалан:

a) якка сўзлардан матн ёзиш (матн турига кўра хикоя хосил бўлади)

Вазфа: 10 тадан 20 тача хар хил сўзлар берилади. Гурухларга бўлинган талабалар улар иштирокида матн тузишади. Агар вақт 8-10 дақиқа билан чеклаб қўйилса жараён янада қизғин тус олади. Мавзу берилмагани маъқул. Шунда бир бирига ўхшаш матнлар хосил бўлишига чек қўйилади.

б) тайёр матнлар бўлагидан матн ёзиш.(матн турига кўра хикоя берилган бўлади)

Вазфа: 3 бўлакка бўлинган матннинг бошланиш қисми 1-гурухга, ўртадаги қисми 2гурухга, 3-гурухга охирги бўлаги берилади. Улар матндаги хикояни фантазияларига кўра бошланишини ёки давомини ёзишади.

в) харфлардан ёки қофияли сўзлардан матн ёзиш. (матн турига кўра шеър хосил бўлади). Вазфа: Хар ким ўз исмининг бош харфларидан бошланувчи от ёки сифатлар билан исмларига шеър ёзадилар ёки таъриф берадилар. Ёки тайёр берилган қофиядош феълларга ёки отларга хар хил хажмда, шаклда шеърлар ёзадилар.

г) расмларга матн тузиш. (матн турига кўра хикоя, қисқа диалоглар, карикатураларга кулгили изохлар хосил бўлади) Вазфа: Гурухларга турлича расмлар берилади ва улар расмларга сарлавха топишади, расмдаги деталларни синчковлик билан кузатган холда уларга хикоя, кулгили изохлар ёзишади, ёки реклама, эълонлар ёзишади. Ёки яна бошқа бир вазифа, яъни мавзуга доир расм икки- уч бўлакка бўлиб гурухларга берилади. Расм бўлаклари бўйича хар бир гурух расмнинг қолган бўлакларида нима борлигини тахминан таърифлаб матн ёзадилар ва расмлар солиштириш учун бирлаштирилади.

Чекланган вақт ичида талабалардан фикрлаш доираларини ишга солувчи,ақлларини чархлаб, луғат бойликларини амалда қўллашга ундайдиган ситуация тузиш, шеър ёзиш каби вазифалар берилса ёзишнинг мароқли жараён эканлигига, дарснинг қизиқарли ва самарали ўтишига эришиш мумкин.

Яна шуни хам таъкидлаш жоизки энг яхшиси гурух бўлиб ишлаш. Чунки, танланган мавзу биргаликда ишлаб чиқилади, фикрлар кўпроқ келади, бирига келган фикрни бошқаси тезроқ ривожлантиради. Шу орқали ўқувчилар ўртасида қизиқарли, хар тамонлама ажойиб, мароқли, интерфаол ва хақиқий мулоқот (коммуникация) юзага келади. Бундан ташқари гурух аъзолари бир бирини тўлдириб бориши туфайли ўйланган фикрлар, ғоялар вариантларга бой, гурух мухокамасидан ўтган, грамматик ва морфологик хатолардан холироқ бўлади. Индивидуал ёзишда фикрларни жамлаш, фантазияни ривожлантириш учун тинчроқ мухит ва бироз кўпроқ вақт керак бўлгани учун уни уйга вазифа тарзида хам бериш мақсадга мувофиқ бўладики, бунда хар бир ўқувчи ўз билим ва махоратини синаб кўриш имкониятига эга бўлади. 
Ушбу амалий таклифлар, замонавий педагогик ечимлар орқали ўқитувчи чет тилини ўқитишда талабаларда дарсга қизиқишини ортишига ва мақсадли бошқара олишга, мотивациясини оширишга, , яъни тил ўрганишга бўлган табиий хохишни ривожлантиришга эришиши мумкин. Тил ўрганиш мажбурий ёки зўриқиб ёдлаш билан эмас балки кучли хохиш билан ўрганилгандагина яхши натижа беради.

\section{Адабиётлар руйихати:}

1. Grätz, Ronald (2001): Vom Spielen, Leben, Lernen. In: Fremdsprache Deutsch: Spielen - Denken Handeln, Heft 25 - 2001S.67

2. Селевко Г.К. «Современные образовательные технологии», М.: 1998.

3. Масылко Е.А. Настольная книга преподавателя иностранного языка.//Изд. «Высшая школа», 2004.

4. Г. Бурханова, Г. Джаналиева, Г.Елдашева,Н. Режаметова, Ф.Бобожонова. Ўқув машғулотларини ташкил этиш ва ўтказиш методикаси. Ўқув-методик қўлланма. Тошкент,2015й.

5. Ж.Жалолов. Чет тили ўқитиш методикаси. Тошкент: Ўқитувчи.1996 й

\section{ХОРИЖИЙ ТИЛДА МУЛОҚОТГА ЎРГАТИШДА ЭМОЦИОНАЛ ФАКТОР ВА УНДАН ФОЙДАЛАНИШНИНГ НАЗАРИЙ АСОСЛАРИ}

\section{Кучибоев Мансур Абдумуротович Хамраев Озод Мелиевич Самарқанд Давлат Архитектура ва Курилиш Институти ўқитувчилари E-mail: manchik.uz@mail.ru}

Annotation: Kuchiboev M.A.Khamraev O.M. The amotional factor Key words : эмоционал and the theoretical basis for its use in teaching communication in a foreign таъсир, аффективлик, language.This article discusses the possibilities of using emotional tools in эмоционал фактор, the process of teaching communication in foreign languages. эмоционал эффект.

Хорижий тилларда мулоқотга ўргатиш жараёнида эмоционал таъсир воситаларидан фойдаланиш имкониятларини ўрганишдан олдин хозирги замон тадқиқотларида «эмоционал таъсир» тушунчасининг турлича талқин қилинишини таъкидлаш жоиз. Масалан, хорижий тадқиқотларда бу ўринда кўпинча «аффективлик» атамаси ишлатилса, рус олимларининг тадқиқотларида асосий урғу масаланинг эмоционал табиатига, яъни бажариладиган иш харакатига эмоционал таъсирнинг барча компонентларини ўз ичига олувчи «эмоционал фактор» атамасидан фойдаланилади.Масалани ўрганишга бағишланган дастлабки тадқиқотларда бу борадаги фикрлар хилма-хиллиги кузатилади. Масалан, П.Я.Якобсоннинг фикрича «эмоционал фактор» тушунчаси анча ноаниқ термин бўлиб, аниқ мазмунга эга эмас.Уни бир томонлама тахлил қилиш жуда мураккаб масала».

К.Д. Шафранская эса ўзининг "Ўкув жараёнида эмоционал факторнинг ўрни» (1976) номли мақоласида бу тушунча ифодаловчи маънолар хақида аниқ фикр билдирмагани холда уни билиш жараёнидаги «эмоционал-хиссий компонентлар», «ўргатишдаги эмоционал эффект», «эмоциген фактор» тушунчалари билан аралаш ишлатади. Бу масалани ўрганишга бағишланган хозирги замон тадқиқотларининг асосий қисмини психологик йўналишда дейиш мумкин. Уларда хам «эмоционал фактор» и «эмоционаллик» тушунчаларикўпинча дифференция қилинмайди.[11-ст.7]: Масалан, Н.В.Колесниковнинг фикрича «эмоционал фактор» атамасиайнан хаяжонни хис қилиш қобилияти деган маънони англатади. «Эмоционаллик» тушунчасини биз «эмоционал фактор» тушунчаси билан яқин маънода ишлатамиз» [12 - с.17].

О.М.Миллернинг бу борадаги тадқиқотида эмоционал фактор куйидагича таърифланади:

1) нутқий фикрнинг мазмуний, лисоний-шаклий, интанцион аспектларини қамраб олиб, нутқий таъсир қилишда регулятив функциясини бажаради; 
2) мулоқот иштирокчиларнинг эмоционал муносабатларининг эркинлигини таъминлайди;

3) эмоционал фактор ўқувчиларнинг ўқув фаолиятини ўрганиладиган ўқув топшириқларига адекват ва самарали равишда бошқаришга ёрдам берадиган қулай психологик мухит яратади " [13 -с.27].

Эмоционал факторнинг психологик тадқиқотларда берилган бундай функционал характеристикаси унинг структурасини ва мулоқот жараёнидаги таъсир кучини ўрганишда кўл келиши мумкин.

Аммо, эмоционал фактордан фойдаланиш имкониятларини ўрганиш бу борада туташ фанларда шаклланган назарий хулосаларга таянилмасдан олиб борилса, хулосалар тўлиқ илмий асосланмасдан қолиши мумкин.

Кейинги пайтларда шаклланган психолингвистика фани хорижий тилларни эгаллашда масалага самарали методик таъсир нуқтаи назардан ёндашиб, эмоционал факторнинг уцрни ва ролига алохида ахамият бермокда. Жумладан, аффектив факторлардан фойдаланиш уларнинг ўзгарувчан характерда бўлишлигини, хар хил нутқий вазиятларда турлича потенциалга эга бўлишлиги туфайли методик қийинчиликларга сабаб бўлишлигини таъкидланмоқда. Шу сабабли хорижий тилларни эгаллашда фойдаланиш мумкин бўлган асосий аффектив факторлар (мотивация, кўрсатма, эмоционал холат) таърифланган холда, уларнинг талқинига, структурасига ва ўзаро бир-бирларига боғлиқликлари атрофлича ёритилмай қолаяпти.

Хорижий тилларда мулоқотга ўргатишда методист олимлар мулоқотни узликсизлигини эмоционаллик орқали таъминлаш, бунда ижобий ва салбий эмоциялардан фойдаланишни кўзда тутишади. Бу холда мулоқотчиларнинг эмоциялари фикрлар алмашувини рағбатлантирувчи, қўллаб - қувватловчи эмоционал омил сифатида функцияга киришади.

Эмотивлик деганда эмоцияларнинг лисоний ифодасини, маънонинг эмотив компоненти деганда эса - тил бирлигига ўзининг эмотивли функциясини амалга оширишга ёрдам берувчи семантик хиссаси тушунилади.

Мазкур ишда эмотивлик деганда етакчи функцияси сўзловчининг эмоциялари ифодаси бўлган тил бирлиги (аффикс, ўзак, хосила сўз, фразеологик бирлик, конструкция) тушунамиз ва нутқни қабул қилувчи унинг лексик маъноси (яъни унинг коннотацияси) эмотив аспектда идрок қилади.

Ўкувчилар ўқув фаолиятининг етакчи омили атрофдаги оламни коммуникатив вазиятларда эмоционал билиш мотивлари бўлиши зарур. Бунда шахс сифатида ўз ўзини намоён қилиш сабаблари биринчи навбатда тургани учун ўқувчилар ушбу билишнинг нутқий хатти -харакатлари ва услубларини ўзлаштиришлари лозим. Биз ўз тадқиқотимизда ўқитиш мотивациясининг А.Н. Леонтьев таърифлаган: “йўналтирилган фаолиятнинг ягона ундовчиси бўлган нарса ўз - ўзича пайдо бўладиган эхтиёж эмас, балки ушбу эхтиёжга жавоб берувчи предметдир" деб изохланадиган назариясига таянамиз.

Шундай қилиб эмоционал таъсир мотивни вужудга келтиради. Мотив - Бу биринчи навбатда инсоннинг ички ва ташқи хаётий, нутқий эхтиёжлари, унинг манфаатлари, мақсад ва вазифалари, унинг фаолиятини фаоллаштиришга йўналтирилган сабаблар натижасидир.

Чет тилларини ўқитишда эмоцияларнинг ўқув фаолиятдаги етакчи ролини эътироф этиб, ўқитувчи ўқувчиларни мулоқотга ўргатиш шароитида уни шакллантириш услублари ва усулларини яхши билиши лозим. Эмоциялар орқали мотивни шакллантирилиши ўқитувчи томонидан ўқувчилар миясига тайёр билимларни ва мақсадларининг “жойлаштирилиши” эмас. Мотивларни шакллантириш - бу аввало ўқишга, фикрлар алмашувига, уларни ўқувчилар томонидан идрок 
қилинишига, уни узликсиз ривожлантиришга ички истакларнинг пайдо бўлиши учун шароит яратилишидир.

Мотивларни шакллантирилишида сухбатдошдан қабул қилинаётган маълумотнинг янгилиги, қизиқарлилиги ўқувчиларнинг изланиш, ўз билимини янада оширишга ва ижодий фаолиятига рағбатлантиради.

Маълумки, чет тиллар ўқитиш жараёнида машқлар ўқитиш воситаларига ёки ўқитиш мазмунининг функционал аспектига мансуб бўлган информацион, операцион ва мотивацион турларга бўлинади. Машқларнинг охирги тури эмоциялар муаммоси, нутқий вазиятлар хосил қилиш уларни ўқувчиларнинг нутқий эхтиёжларига мослаштириш , бу орқали нутқий фаолиятга ёрдам берувчи қобилиятларни шакллантириш ва такомиллаштириш билан чамбарчас боғлиқдир.Бугунги кунда бундай машқларни мулоқот (коммуникатив топшириқлар) машқлари деб аташ қабул қилинган.

Бундай турдаги машқлар мулоқот иштирокчиларининг ўзаро муносабатлари ва ўзаро таъсирларини фаоллаштиришни таъминлайди, фикрлари мотивлашишишга ёрдам беради.Шундан коммуникатив топшириқларни бажаришдаги жуфт бўлиб, гурух бўлиб ишлашни ташкил қилишнинг методик тамойиллари келиб чиқади.

Хулоса қилиб айтганда,мулоқотга ўргатувчи машқларнинг эмоционаллиги, аниқроғи улар асосида хосил қилинган рухий қувват индивидни атрофдаги воқелик билан муносабатга киришувига йўналтиради. Масалан, фикрлар ёки хотиралар кишини гапиришга ундайди, хис - туйғулар эса тана харакатларини келтириб чиқаради, мимика ва имо - ишоралар, юзага келган образлар онгли хаттихаракатларни келтириб чиқаради, фаолиятда моддийлашади. Шу нуқтаи назардан «эмоция» тушунчаси мулоқот материалини узатишда ва қабул қилишда руй берадиган рухий холатни ифодаласа, «эмотивлик» бу ахборотни ўзлаштиришдаги рухий холатнинг меъёрини, интенсивлигини белгилайди.

\section{Адабиётлар рўйхати:}

1.Абдуллаев Ю.Н., Бушуй А.М. Коммуникативная методика обучения иностранным языкам и зарубежный педагогический опыт Уч. пособие. Самарканд, 2001, 125 с.

2.Абдуллаева М.А. Коммуникативная методика обучения иноязычной грамматике на начальном этапе языкового факультета (на материале Presentcontinuous, presentperfect английского глагола.) Дисс. на соиск. уч.ст. канд.пед наук. Худжант,2004 .189 с.

3.Абдуллаева Ш.А. Развитие эмоционально-образной русской речи учащихся школ с узбекским языком обучения (на материале произведений русской литературы. Автореферт на соиск. Уч. Ст. к.П.н. Т.,1998. 25 с.

4.Аверина М.Н.Обучение использованию эмоционально экспрессивных лексических средств речевой коммуникации (английский язык, лингвистический вуз): Дис.... канд. пед. наук. - М., 1996. - 183 с. 5.АвлиёқуловН.X «Замонавий ўқитиш технологиялари» Т. 2001.

6.Ананьева М.М. Использование невербальнвх средств общения на уроках французского языка. \\Иностранные языки в школе. М.:,1999.№5. с.19-26

7.Ариян М.А. Повышение самостоятельности учебного труда школьников при обучении иностранным языкам. \\Иностранные языки в школе. М.:,1999.№6. с.19-21.

8.Баженова Н.Г. Невербальные средства общения в обучении французскому языку. \\ Иностранные языки в школе. М.:,1998.№3. с.8-11.

9.БеспалькоВ.П. Педагогика и прогрессивные технологии обучения. М.: Педагогика, 1995.

10.Бим И.Л. Некоторые актуальные проблемы современного обучения иностранным языкам. \\ Журнал «Иностранные языки в школе», 2000, №4, с.4.

11.Шафранская К..Д. Роль эмоционального фактора в учебном процессе // Современные психологические проблемы высшей школы. - Л., 1976.ст.7.

12.КолесниковН.В. эмоционал фактор речи// Иностранные языки в школе. М.:,1999.№5. с.17-26.

13.Миллер О.М.Проблемы средства общения Иностранные языки в школе. М.:,1994.№3. c.27-32. 


\section{А. МОРУА НОВЕЛЛАЛАРИНИНГ ФРАНЦУЗ ТИЛИ ДАРСЛАРИНИ ТАШКИЛ ҚИЛИШДАГИ ЎРНИ ВА АЙРИМ ХУСУСИЯТЛАРИ}

\section{Отамуродова Дилафруз Рахмановна Ўзбекистон давлат жахон тиллари университети катта ўкитувчиси E-mail: otamurodovadilafruz@gmail.com}

Annotation: In this article it is discussed the self-study of a student and few features of arranging that kind of stuffson the example of short stories by Andre Mauro. Particularly, this incident is profoundly illustrated in the process of French lessons. Furthermore, different sorts of self-study and their implementations are analyzed in the article.

Key words : self-study, curriculum, subject, theme, plan, lecture hall, teacher, student, short stories.

Тилни ўрганиш анча мураккаб жараёнлигига ахамият қаратадиган бўлсак, шуни айтиш лозимки, талабаларнинг умумий хусусиятлари ва фарқли томонлари ўқув дастурлари буйича белгиланган мавзуларга оид маълумотларни фақат бир дарс машғулотида қамраб олиш ва талабаларга етказишдаги қийинчиликлар мустақил ишларни ташкил қилиш ва назорат қилиш заруриятини келтириб чиқаради ва натижада талабанинг мустақил ишлаши таълим жараёнида мухим ўрин касб этади. [1, 338]

Талабанинг мустақил иши - бу муайян фандан ўқув дастурида белгиланган билим, кўникма ва малаканинг маълум бир қисмини талаба томонидан фан ўқитувчиси маслахати ва тавсиялари асосида аудитория ва аудиториядан ташқари ўзлаштирилишига йўналтирилган тизимли фаолиятдир. Демакки, хар бир талаба дарсдан ташқари мустақил шуғулланса, изланса, интилса кўпроқ билимга эга бўлади. Чет тили дарслари ўзга нутқни яхшироқ тушунишга, ижтимоий-сиёсий ва эстетик мавзуларда бахсга кириша оладиган, турли хил ўзлаштириши енгил бўлган адабиёт, газета материалларини луғатсиз тушуниб, мустақил фикрлайдиган, ўз қарашларини эркин ифодалай оладиган қилиб тарбиялашга ёрдам беради. Бундан ташқари у талабаларга тили ўрганилаётган мамлакат урф-одатлари, тарихи, адабиёти, санъати хақида мукаммал маълумотга эга бўлади. [5,2]

Мустақил ишларни ташкил этишдан кўзланган мақсадга эришиш учун ўқитувчи аввало ўкув дастурларига киритилган мавзулар осон ва мураккаблиги, ўзлаштиришдаги қийинчиликлар даражасини гурух талабалари кесимида ўрганиб, аниқ мақсадли режа асосида фаолият юритиши лозим. Бундан ташқари талабанинг 3курсда ўқишини ва 1, 2-курсга нисбатан ўзлаштириши керак бўлган билим ва кўникмалар кенглигини хисобга олиши, талабанинг мустақил билим олишини тўғри ташкиллаштиришга ўргатиб бориши зарур. [3, 167]

Юқоридагилардан келиб чиқиб француз тили йўналиши 3-курсида мустақил ишларни шартли равишда икки турга ажратиш мумкин:

1) аудиторияда бажариладиган мустақил ишлар. Бунга ўтилган мавзуни кенгайтириш, мустахкамлашга оид топшириқларни бажариш каби ишлар киради. Бунда ўқитувчи талабанинг ўтилган мавзулар (масалан Моруа новеллалари) бўйича ўзлаштириш даражаси, дарс машғулотларига тайёргарлик савияси, берилаётган топшириқларнинг бажарилиш сифатини текшириш мақсадида савол-жавоб, сухбат, бахс-мунозара ўтказиши, машқлар бажарилишини назорат қилиши мумкин.

2) аудиториядан ташқари бажариладиган мустақил ишларга ўқув дастуридаги айрим мавзуларни мустақил ўзлаштириш, уйга берилган вазифаларни ўз вақтида тайёрлаш киради. Бунда эса ўқув дастури ва календарь-тематик режага киритилган мустақил иш мавзулари асосида талаба маълумотлар тўплаши (А.Моруа 
хаёти ва ижоди тўғрисида), рефератлар (мас. Моруа новеллалари ёки муайян новелла юзасидан), курс ишлари (3-курсдаги лексикология, тили ўрганилаётган мамлакат адабиёти фанларидан), тезислар, маърузалар, тестлар, саволлар ва топшириқларни Моруа асарлари бўйича тайёрлаши мумкин. Аниқроқ қилиб айтадиган бўлсак, француз тили дарсларида Андре Моруа новеллаларининг мустақил ишлар шаклида тизимли ўтказиш, бажариш хамда натижасига қараб уларни турли хил шаклларда ташкил қилиш мумкин.

Хозирги кунда таълим жараёнида талабалар билимини бахолашда мустақил ишларга алохида урғу берилиб, унинг асосий вазифаларидан бири талабаларда мустақил ишлаш кўникмаларини ривожлантириш, ахборот ресурслари манбаларидан самарали фойдаланишни ташкил этишдан иборат. Шунинг учун хам талабаларнинг ўқув фани бўйича мустақил иши жорий, оралиқ ва якуний назорат жараёнида тегишли топшириқларни бажариши ва унга ажратилган баллардан келиб чиққан холда бахоланади. [5,8]

Бу вазифалар қуйидагилар:

1) Мавзу бўйича новеллаларни мустақил ўзлаштириш. Бунда талаба мавзуни очиб берадиган таянч сўз ва ибораларни топади, таржима қилади, маъно жихатидан қўлланиши (définition, acception)га ахамият беради, саволларга жавоб беради, новеллани баён (résumé) қилади, новелла юзасидан берилган машқларни мустақил бажаради, жавобларини ўқитувчига ёзма равишда кўрсатади ёки аудиторияда ўқитувчи рахбарлигида бажаради, ўзлаштириш қийин бўлган вазифалар бўйича ўқитувчидан маслахат олиб, уйда бажаради.

Талаба уйда ўз-ўзини текшириш учун берилган топшириқларга, саволларга жавоб бериши мустақилликка ўргатади. [2, 241]

2) Ўтилаётган новелла бўйича реферат тайёрлайди. Бунда талаба қўшимча адабиётлар, электрон кутубхона ёки Интернет маълумотларидан фойдаланган холда мавзуни кенгроқ ёритиб, янги маълумотлар билан бойитишга харакат қилади.

3) Муаллифлар (асарлардан келтирилган парчалар, хикоя, новеллалар муаллифлари) хаёти ва ижоди хақида қушимча маълумотлар топади. Агар «La Cathèdrale» ("Ибодатхона") новелласи бўлса, рассомлар, уларнинг асарлари ва талқинлари, ижод йули хақида; «Les violettes du mercredi» (“Чоршанба бинафшалари”) бўлса, унда актёр ёки режиссёр, у суратга олган кинофильмлари ёки суратга тушган кинолари хақида; агар “Myrrhine” ("Миррина”) бўлса, театр асарлари, театрлар тарихи, намоёндалари хақида қизиқарли маълумотлардан реферат тайёрлаши мумкин.

4) Ўрганилаётган новелла бўйича кўргазмали қуроллар - чизмалар, схемалар, жадваллар, слайдлар тайёрлаши мумкин.

5) Новелла юзасидан тестлар, асосий ғояни очиб беришга хизмат қиладиган саволлар, топшириқлар тузиши мумкин.

6) Талаба ўзи хохлаган новелласи бўйича талабалар илмий конференцияларида ўз маърузалари билан иштирок этиши мумкин.

7) Ўз қизиқишидан келиб чиқиб, танлаган новелласи бўйича турли хил фанлар (Лексикология, Стилистика)дан курс ишларини тайёрлаб, уни химоя қилиши мумкин. Бунда мавзунинг долзарблиги, талабанинг ижодий ёндашиши, мавзу мақсадининг асосланганлиги хисобга олинади. Шу ўринда айтиб ўтиш лозимки, талаба курс ишини тегишли фан буйича тўплаган баллари умумлаштирилишига қадар топшириши шарт.

8) Иқтидорли талабалар ўзларини қизиқтирган мавзулари бўйича Моруа новеллалари асосида илмий рахбарлари хамкорлигида тезислар, илмий мақолалар чоп этишлари ёки илмий-амалий анжуманларда иштирок этишлари мумкин.

Хозирги кунда республикада илмий салохиятни кўтариш ва чуқур илмий салохиятли кадрларни етишиб чиқишига шарт-шароит яратиш масаласи долзарб хисобланади. Айтиш жоизки, бугунги кун талабаларининг илмий-тадқиқот ишлари 
билан шуғулланишга интилишлари, қизиқишлари ортиб бормоқда. Шундан келиб чиқиб, талабаларнинг Моруа новеллалари асосида мустақил фикрлашларини ривожлантириш; мустақил ишлар мавзуларини илмий-тадқиқот ишларига йўналтириш; мустақил ишларни оддий савол-жавоб ёки реферат тарзидагина эмас, балки талабаларни кўпроқ илмий-услубий ишларга йўналтирган холда, уларни қўшимча илмий-бадиий адабиётлар, ўз мутахассисликларига доир илмий мақолаларни ўқиш орқали мавжуд назарий фикрларни қиёслаб ўрганишга, маълумотларни илмий тахлил қилишга йўналтириш мақсадга мувофиқдир. [4, 35]

Талабанинг француз тилини ўзлаштиришида мустақил ишларнинг роли ахамиятли бўлиб, у тилни мукаммал ўзлаштириш имконини беради, бу эса ўз навбатида келажакда етук, ўз сохаси бўйича билимдон, ақли теран, чукур мушохадали кадр бўлиб етишиш мақсадини вазифа қилиб қўяди. Бинобарин, юқори курсда ўқиш талаба учун етакчи амалий мақсад мақомини эгаллайди. Шундай экан, талаба ва ўқитувчи ўртасида қўйилган вазифаларга мақсадли ёндашиш, умумфикрлилик, ўзаро хамкорлик устун бўлиши лозим. Албатта бу вазифалар бевосита ўқитувчи рахбарлиги остида амалга оширилади, чунки бунда ўқитувчи йўл-йўриқлар кўрсатувчи, талабани қўллаб-қувватлаб ёрдам берувчи хисобланади.

Зеро, талабаларни дарс машғулотларида ўқитиш билан бир қаторда уларни кўпроқ ўқишга ўргатиш, билим олиш йўлларини кўрсатиш, мустақил таълим олиш учун йўлланма бериш олий таълим муассасасининг асосий вазифаларидан бири хисобланади.

\section{Фойдаланилган адабиётлар:}

1. Жалолов Ж. Чет тили ўқитиш методикаси. Т., “Ўқитувчи”, 1996, 338-бет

2. Хошимов Ў., Ёқубов И. Инглиз тилини ўқитиш методикаси. Т., "Шарқ” 2003, 241-бет

3. Гез Н.И., Лиховицкий М.В., Миролюбов и др.-М: Методика обучения иностранным языкам. М., «Высшая школа», 1982, 167-бет

4. Мухиддинова Х. Талабаларнинг илмий услубини шакллантириш. “Филология масалалари" журнали, 2007/2(15)-сон, 35-бет.

5. Ўзбекистон Республикаси Олий ва ўрта махсус таълим вазирлигининг 2009 йил 14 августдаги “Талабалар мустақил ишларини ташкил қилиш тўғрисида" ги 286-буйруғи ва ушбу буйруққа 1-илова "Талабалар мустақил ишларини ташкил қилиш ва назорат қилиш бўйича Йўриқнома"

\section{BOSHLANG'ICH SINFLARDA \\ O'QISH KO'NIKMALARINI SHAKLLANTIRISH XUSUSIYATLARI}

\section{Ummatova Xonimoy Amonovna Samarqand viloyati Jomboy tumani 40 -IDUM o'qituvchisi}

Annotation: This article discusses how to teach reading skills in the primary grades in accordance with the language lessons, and it is about the competencies a student can have.
Key words : o'qish, yozish, grammatik material, ko'nikma, malaka, konpetensiya, zamonaviy texnologiya.

Boshlang'ich sinflarda ona tili o'qitish metodikasi yuqori sinflardaona tili o'qitish metodikasining dastlabki bosqichi bo'lib, u tekshiradigan masalalarni boshlang'ich sinf o'quvchilariga tadbiqan (muvofiq ravishda) o'rgatadi. Shu bilan birga, boshlang'ich sinflardaona tili o'qitish metodikasining o'ziga xos xususiyatlari mavjud. Boshlang'ich sinflardaona tilini o'qitish grammatika, imlo va unga bog'liq holda nutq o'stirish metodikasinigina emas, balki xat-savod o'rgatish, sinfda va sinfdan tashqari o'qish metodikalarini ham o'z ichigaoladi.[2] Shu jihatdan, ona tili fani o'qish fani bilan integrallashgan holdaolib boriladi. 
Yuqoridagilardan kelib chiqib, boshlang'ich sinflardaona tili o'qitishning turi va mazmuni quyidagicha:

- o'qish, yozish, grammatik materialni o'rgatish, kuzatishlar hamdao'quvchilarning ijtimoiy faoliyat bilan bog'liq holda ularning og'zaki va yozma nutqini rivojlantirish:

- o'qish va yozish ko'nikmalarini malakalargaaylantirish;

- adabiy til no'rmalarini, yani imloviy va pinktuatsion savosli yozuvni, orfoepik to'g'ri talaffuzni o'rgatish, ifodali nutq va stilistik (uslubiy) elementlarni o'rgatish;

- o'quvchilarning grammatika vao'qish darslari orqali badiiy, ilmiy ommabop va boshqaadabiyotlar bilan tanishtirish, ulardaasarni idrok qilish ko'nikmalarini shakllantirish.

Ona tili darslaridan olgan bilim va malakalarni ko'nikmalargaaylantishishdao'qish darsining ahamiyati katta. o'qish jarayonidao'quvchilar quyidagi konpetensiyalarga ega bo'lishlari mumkin:

- $\quad$ nutqiy kompetensiya;

- axborot bilan ishlash kompetensiyasi;

- o'zini o'zi rivojlantirish kompetensiyasi;

- milliy va umummadaniy kompetensiya.

Bu kompetensiyalar o'z navbatida quyidagilarni o'z ichiga oladi:

\begin{tabular}{|c|c|c|c|}
\hline $\begin{array}{c}\text { nutqiy } \\
\text { kompetensiya }\end{array}$ & $\begin{array}{c}\text { axborot bilan } \\
\text { ishlash } \\
\text { kompetensiyasi }\end{array}$ & $\begin{array}{c}\text { o'zini o'zi } \\
\text { rivojlantirish } \\
\text { kompetensiyasi }\end{array}$ & $\begin{array}{c}\text { milliy va } \\
\text { umummadaniy } \\
\text { kompetensiya }\end{array}$ \\
\hline $\begin{array}{c}\text { berilgan topshiriq, } \\
\text { sodda matnlarni } \\
\text { tinglash, o'qish, } \\
\text { yozish orqali nutqni } \\
\text { rivojlantirish }\end{array}$ & $\begin{array}{c}\text { o'qilgan yoki } \\
\text { tinglangan matn } \\
\text { mazmunidan zarur } \\
\text { ma'lumotlarni izlab } \\
\text { topish, saralash }\end{array}$ & $\begin{array}{c}\text { doimiy ravishdao'qib } \\
\text { o'rganish, bilimini } \\
\text { oshirib borish, } \\
\text { ijodiylik } \\
\text { rivojlantirish }\end{array}$ & $\begin{array}{c}\text { berilgan matnlar } \\
\text { mazmuni orqali } \\
\text { milliy va }\end{array}$ \\
umummilliy \\
qadriyatlarni \\
shakllantirib borish
\end{tabular}

$\mathrm{Bu}$ kabi ko'nikmalarni shakllantirishda zamonaviy ilg'or texnologiyalardan foydalanish yaxshi samara beradi.

Zamonaviy ta'limning yangi tizimi va mazmunini shakllantirish uchun ilg'or texnologiyalarni hamda o'quv-tarbiyaviy jarayonning didaktik ta'minotini yaratish, ta'lim mazmunini innovatsion yondashuvlar asosida tashkil etish kerak. Bu muhim vazifani ijobiy hal etilishi ta'lim jarayonini tashkil etishga nisbatan yangicha yondashuvni taqozo qiladi. Boshlang'ich ta'lim tizimining barcha bosqichlarida ta'lim jarayonining samaradorligini oshirishga xizmat qiluvchi omillarni izlab topish, bu borada eng maqbul omil deb topilgan ilg'or pedagogik va axborot-kommunikatsiya texnologiyalarini tatbiq etish zarurdir. [1] Boshlang'ich ta'lim jarayoniga axborot-kommunikatsiya texnologiyalari va multimedia vositalarining qo'llanilishi nafaqat o'qituvchi faoliyatiga, balki o'quvchi shaxsining har tomonlama rivojlanishi hamda shakllanishiga asos bo'lmoqda.

o'qish jarayonida turli zamonaviy texnologiyalardan foydalanish bo'yicha fikrlarimiz bilan o'rtoqlashishni lozim deb topdik.

«Rezyume» texnologiyasi murakkab, ko'p tarmoqli, mumkin qadar muammoli mavzularni o'rganishga qaratilgan. Texnologiyaning mohiyati shundan iboratki, bunda bir yo'la mavzuning turli tarmoqlari bo'yicha axborot beriladi. ayni paytda ularning har biri alohida nuqtalardan muhokama etiladi. Masalan, ijobiy va salbiy tomonlari, afzallik va kamchiliklari, foyda va zararlari belgilanadi. 
Maqsadi: o'quvchilarni erkin, tanqidiy fikrlashga, jamoa bo'lib ishlashga, izlanishga, fikrlarni jamlab taqqoslash uslubi yordamida mavzudan kelib chiqqan holda uning muammosini, yechimini topishga o'rgatish.

Vazifasi: o'quvchilarni kerakli xulosa yoki qaror qabul qilishga, jamoaga $\quad o^{\prime} z$ fikri bilan ta'sir o'tkazishga, uni ma'qullashga, shuningdek, berilgan muammoni yechishda, mavzuga umumiy tushuncha berishda o'tilgan mavzulardan egallagan bilimlarni qo'llay olishga o'rgatadi. [1] Masalan: Derek Munsonning "Dushman perogi" hikoyasi o'qish uchun berilgan bo'lsa, o'quvchilarga hikoya qahramonlari Jeremi, Tom va Stenlining xaraktiri, qiziqishlari haqida bilganlarini so'zlab berishi so'ralishi orqali ularda eng sodda tushunchalar xosil bo'lgani tekshirib olinadi, yani personajlarning salbiy va ijobiy hislatlari sanab o'tiladi. Shundan so'ng o'quvchilarga dushmanlikning sabablarini keltirish so'raladi va shu tarzda davom ettiriladi.

Mustaqil o'qish uchun qo'shimcha turli matnlardan foydalanishimiz ham mumkin, bunda turli uslublardagi, turli millat vakillari madaniyatini o'zidaaks ettiradigan matnlardan foydalangan holda dars olib borilsa, turli ko'nikmalarni egallash bilan birgalikda, dunyoviy, madaniy, ilmiy bilimlarga ham ega bo'lishi mumkin.

\section{Foydalanilgan adabiyotlar:}

1.Boymurodova G., Sattorova X. va boshqalar "o'QISH", 3-sinf o'qituvchilari uchun ilg'or pedagogik va axborot-kommunikatsiya texnologiyalarini amaliyotga joriy etish bo'yicha metodik qo'llanma. Toshkent - 2016

2. Qosimova K. , Matchonov S. va boshqalar "ona tili o'qitish metodikasi", "Nosir " nashriyoti, Toshkent-2009

3.Xalqaro tadqiqotlarda boshlang'ich sinf o'quvchilarining o'qish savodxonligini baholashmetodik qo'llanma, "Sharq" nashriyoti, Toshkent-2019

\section{TEACHING TECHNIQUES ON GRAMMAR IN CONTEXT}

\section{Holmatova Gulnoza Bahtiyor qizi Teacher, Uzbek State World Languages University}

Annotation: Grammar instruction is one of the most difficult issues of language teaching. Developing different techniques on grammar teaching holds an important place for effective learning. It will be more motivating for learners if grammar is taught in context as learners will have an opportunity to perceive how the new grammar structures work. This article explains why we should teach grammar in context using varieties of modern techniques.
Key words : assimilation, apprehend, expedient, generalization, confusion, consolidate, jigsaw.

Without knowing grammar the pupils cannot comprehend the listening information and the content of the any text or cannot write or express their minds. Knowing the words is not adequate for the speech activities. They must be put, used according to the grammar rules, structures. Otherwise, your sentences may not be understandable at all. Only putting words in the correct grammar structure can express the information accurately. Assimilation of every grammar rules is classified by the formation of automatized skills of speech grammar. We know that teaching grammar should closely be connected with teaching vocabulary, phonetics, reading, writing and oral speech and they are all a component of grammar. From the history of the English language we know that for learning grammar was paid much attention in language teaching for a long period of time. Therefore the grammar is the basic language material of the speech activity, teaching grammar is necessary, must be learned, studied, taught at schools, lyceums, colleges. Teaching English grammar has its structure. 
Grammar rules of the English language in our brains should be as automatic and familiar to us as to native speakers that we should apprehend when the rules are being violated. Many factors may cause pupils to make mistakes in learning grammar. That's why learning English grammar according to its methods and principles is expedient.

Teaching English grammar has its principles, methods and they play a great role, cooperate to use the grammar material in a correct way in speech. Pupils learn any grammar item which is necessary for them in practical approach to the assimilation of grammar. From the first steps of learning the language pupils are taught to understand English and to speak the language. Therefore the teacher should instruct pupils correct grammar usage. We should use the principle of analogy extensively because of its importance and impact on improving grammar level. For pattern we can take Russian language in order to compare it to the English grammar. Because there are similarity and closes between their grammar. They are coincided in word orders (we go to school - мыпойдёмвшколу), tenses (I will go ябудупойти), and both of them have the prepositions. It makes you somehow easy to assimilate grammar.

The system of teaching grammar is formed from developing grammar skills, acquiring grammar material and learning generalization. In its turn it requires doing exercises aimed at developing skills and acquiring the material. In short exercises are means of overcoming difficulties of structures and assimilation of actions and generalizations. There are some useful methodical experience aimed at teaching English grammar:

- One aspect which should be paid more attention is to begin to learn grammar step by step, namely, learning the basic grammar rules first before passing to common rules is advisable. In many circumstances pupils come across to grammatical confusion during the process of assimilation grammar. Because the majority of pupils ignore the main grammar roots, therefore they have difficulty exploring the grammar. In order to master the grammar, it is necessary to study in order. For instance, before learning the verbs, the main verb "to be" should be taught.

- Pupil should differentiate new structure from the other known structures such as adjective and adverb. They are similar to each other, because adverb is distinguished from adjective only with suffix -ly. But sometimes they both may be the same: fast, late, early, hard...

- It is preferable to name every difficult given structure. By the way it cooperates you to memorize well.

- During exercises it is essential to analyze every sentence from grammatical point of view.

- We should take into account vocabulary as well. Extending vocabulary by learning every new word in grammar books and materials is the best way of improving your speaking too.

- Another important rule is to memorize word order in sentence: $\mathrm{S}+\mathrm{V}+\mathrm{O}$ etc.

- Doing extra handouts or using other grammar materials helps to consolidate studied grammar rules.

- To attempt to make up conversation applying the appropriate structures and to use different tenses, modal verbs and linking words as much as possible so that it would not be too short. The usage of grammar in the speech activities makes pupil recollect the rules (s)he learnt.

- Individual approach to grammar makes our brain work hard

- Playing various and interesting games, quiz, puzzles, jigsaws dependent on grammar increases pupil's enthusiasm to learning grammar better.

- Reading and repeating grammar rules may not help pupils to remember them after some days. The best way of recollecting every tiny rule is to discover a new method of 
exploring which is easy to apprehend to you. For this they may use any kind of structure such as pictures, short notes, diagrams, graphs and so on. They will grant possibilities and comforts to keep the rules in mind.

- To use music or song in order to simplify to learn or practice grammar rules.

- To work in pair and one gives any question belongs to grammar, second answers (quiztrade).

- To watch easy cartoons which constructed correctly and simply by grammatical sides

- To translate the short text or paragraph that includes complicated structure, word formation etc.

If pupils focus on learning grammar first, they will create a fundamental principle in language learning. Because the grammar is considered as a base of any language as well as English language. Grammar names the types of words and word groups that make up sentences not only in English but in any language. Thus, it is so important to be aware of its grammar of English language before speaking, listening, reading and writing. For common comprehension it requires to know grammar perfectly than the others. Being able to use all the taught, learned, studied English grammar in speech activities is obligatory.

\section{References:}

1. J.J. Jalolov, G.T.Makhkamova, Sh.S. Ashurov - English Language Teaching Methodology -Tashkent, 2015. P. $128-138$.

2. David Nunan - Language Teaching Methodology - Macquarie University, 1991. P. 149 - 166.

3. I. Yoqubov - Comparative methods of teaching English at schools, lyceums and colleges - Tashkent, 2014. P. $75-88$

4. Theory and Practice in Langauge Studies, Vol. 3. No.1, pp. 124-129, January 2016

\section{EFFECTIVITY OF GAMES ON IMPROVING THE VOCABULARY OF PRIMARY LEARNERS}

\section{Holmatova Gulnoza Bahtiyor qizi Teacher, Uzbek State World Languages University}

\section{Annotation: Teaching a foreign language is challenging task to do, so} creating a playful and enjoyable context is essential for children to develop their overall language proficiency. English is developing as a second language all over the world and several methods of teaching are being created to English. One of them is game based on vocabulary. The aim of creating game among young learners is to

Key words Game, multimedia, warm-up activity, task-based activity. increase their interest and explain that learning process can be playful.

A game is an organized activity that usually has the following properties: a particular task or objective, a set of rules, competition between players, and communication between players by spoken or written language (Richards, Platt, 1992).

According to Nation, in order to acquire vocabulary, students are to be challenged and focus their attention to new strategies. Games can be different in such aspects as theme, intended audience, human-computer interface, graphical fidelity, hardware and interaction between players. A number of studies have revealed that games can have positive effect on achievement, interest, task learning engagement and problem solving. In the context of a game vocabulary skill can be acquired without pressure.

Games have been shown to have advantages and effectiveness in learning vocabulary in various ways :

- Games bring relaxation and fun for students, thus help them learn and retain new words easily; 
- Games usually involve friendly competition and they keep learners interested and motivated;

- Vocabulary games bring real world context into the classroom, and enhance students' use of English in a flexible, communicative way.

Therefore, the role of games in teaching and learning vocabulary cannot be denied. However, in order to achieve most from vocabulary games, it is essential that suitable games are chosen. Whenever a game is to be conducted, the number of students, proficiency level, cultural context, timing, learning topic, and the classroom settings are factors that should be taken into account.

Multimedia games play main role in improving vocabulary. They increase motivation and foster a deeper processing of vocabulary. Word memorization is important in language learning, and memorization is helped when words are recycled regularly. Vocabulary development is a continuous process, where learners meet the words many times in their learning to increase and deepen their knowledge and their use of words in foreign language . It is also facilitated through using meaningful activities to practice vocabulary, as it provides the learners with opportunities to memorize the words effectively, more than if they just practice them orally by drilling or by using flashcards. Memory is crucial in vocabulary learning and the benefits of revision and repetition have been clearly demonstrated in studies of vocabulary teaching .

In order to learn and retain new words, learners should participate in different taskbased activities in their classroom and such activities also include vocabulary games which especially focus on helping learners develop and use words in different contexts by making the lessons enjoyable. Haldfield [1, p.8] said that games can take one of the following forms:

a. Information gap. Students ask their partners to get missing information to complete the task or card they have or together solve a problem.

b. Guessing games. The player with the information deliberately withholds it, while others guess what it may be.

c. Search games. Players must obtain all or a large amount of the information available to fill in a questionnaire or to solve a problem.

d. Exchanging games. Players have certain articles, or ideas which they wish to exchange for others. The aim of the game is to make an exchange that is satisfactory to both sides.

e. Collecting games. Players need to collect cards in order to complete a set.

f. Arranging games. Players must acquire information and act on it in order to arrange themselves in groups.

In conclusion, according to scientists' opinion, game is an organized activity in order to make the lesson process more interesting. Learning vocabulary through games is one of the most effective and interesting ways that can be applied in any classroom. Taking in account the results of the factors mentioned above the article can be summarize the suggestion of using games not only for mere fun, but more importantly, for the useful practice and review of language lessons, thus leading toward the goal of improving learners' communicative competence. In learning a foreign language, vocabulary plays an important role. It is one element that links the four skills of speaking, reading, writing, and listening all together.

\section{References:}

1. Haldfield K. (1999). Beginners' communication games. London: Longman.

2. Nation I. (1990). Teaching and learning vocabulary. Massachusetts: Heinle \& Heinle Publisher.

3. O'Dell F. (1997). Incorporating vocabulary into the syllabus: Cambridge University press.

4. Richards J.C., Platte J. and Platte, H. (1992). Dictionary of language teaching and applied linguistics. London: Longman. 


\section{ХОРИЖИЙ ТИЛЛАРНИ ЎҚИТИШДА МАДАНИЯТЛАРАРО МУЛОҚОТ КОМПЕТЕНЦИЯЛАРИНИ ШАКЛЛАНТИРИШНИНГ АХАМИЯТИ}

\section{Юсупова Дилфуза Икромовна Ўзбекистон Давлат Жахон Тиллари Университети мустақил тадқиқотчиси, Гёте-Институти ўқитувчиси E-mail : d asl yusupova78@yahoo.de}

Annotation: This article is about the importance of building intercultural communicative competence in foreign languages teaching. The topicality of the problem is justified from different perspectives of the methodology.
Key words: language, culture, intercultural communication, intercultural competence, sociocultural competence, CEFR.

Хорижий тилларни ўқитишнинг мақсади хар доим давр талабига мос белгиланган. 21 асрда жахон майдонида дунё мамлакатларининг ривожланиш тенденцияси янги, глобаллашув палласига ўтган пайтда чет тилларини ўрганиш ва ўқитишнинг мақсад ва вазифалари хам янгича тус олди.

Бугун хох у ўқувчи, хох талаба бўлсин нафақат хорижий тилни билиши, балки ўша тил вакиллари билан рисоладагидек муомала қила олиш лаёқатига эга бўлиши лозим. Шу ўринда, мамлакатимизнинг методика сохасидаги таниқли профессори Ж.Жалоловнинг “[...] тил, шу жумладан ўзга тил бир вақтнинг ўзида тили ўрганилаётган мамлакат ёки тил сохибининг маданияти ифодаси сифатида ўрганилади. Шунинг учун сўнгги ўн йилликда тилни маданият билан бирга ўқитиш, масалан, инглиз тили ва маданиятига ўқитиш масалалари жадал ўрганилмоқда. Бизнинг фикримизча, ўқув предмети хам шундай номланиши лозим (таржима бизники - Д. Ю.)." [1. б.90] деган фикрлари бу масаланинг қанчалик ахамиятга молик эканлигидан далолат беради. Эндиликда чет тилларини ўрганишда асосий урғу грамматикага берилмайди ёки таржима қилиш дарснинг буткул мақсади қилиб белгиланмайди, аксинча ўқувчида коммуникатив, социолингивистик компетенцияларни шакллантириш чет тили дарсларининг асосий вазифаси хисобланади.

Мазкур мақолада, маданиятлараро мулоқот юритиш компетенцияси ўзи нима ва нима учун у хозирги кунда хорижий тилларни ўқитишнинг ажралмас бир қисмига айлангани ва бунинг зарурияти халқаро тажрибалар асосида мулохаза қилинади.

Бунинг учун мақолада дастлаб муаммонинг долзарблиги асослаб берилади. Ундан кейин эса бу жараённи юзага келиш сабабларини ёритиш мақсадида чет тилларни ўқитиш методикаси тарихига назар солинади. Мақола сўнггида эса маданиятлараро мулоқот юритиш компетенцияси коммуникатив-дидактик методга йўналтирилган чет тили дарсларининг дидактик-методик тамойилларидан бири этиб белгиланганлиги тўғрисида фикр юритилади.

Маданиятлараро мулоқот юритиш компетенцияси тушунчасига аниқлик киритиш мақсадида ўзбек-немис маданиятлараро мулоқотидан бир мисол келтирамиз.

“Ўзбекистонлик тадбиркорнинг Германия сафари хотираларидан. Кунлардан бирида германиялик тадбиркорлардан бири уузбекистонлик шеригини кечки овқатга таклиф этади. Сухбат немис тилида кечади. Саломлашишдан сўнг бир оз жимлик чўкди, сухбатни қцздириш учун ўзбекистонлик тадбиркор шеригига саволлар билан мурожаат қила бошлади. "Ишларингиз яхшими? Уйланганмисиз? Болалардан нечта? ... Сизларда одамларнинг маоши құанча? Бир ойда құнна маош оласиз?” ва хакозо. Савол орқасидан 
савол кела бошлади, "Нега? Нима учун?" Негадир немис сухбатдошининг кайбияти, афти-ангори ўзгара бошлади, ва қцсқа құлиб, "Кечирасиз, бу менинг шахсий ишим, булар сизни қизиқтирмасин”, дея жавоб берди. Кутилмаганда бу жавобдан ватандошимизнинг кўнгли оғриб, сергак тортади. Икки томон хам вазмин тортди. ... Нокулай жимлик, ўнғайлик. Режалаштирилган хамкорлик яна орқага сурилди ва нимагадир амалга ошмади."

Мазкур муаммоли холатни тахлил қилишга харакат қилиб кўрамиз. Аслида ватандошимиз немис тилини мукаммал билади, хеч қандай бир ёмон харакат қилгани йўқ. У фақат сухбатдоши билан яқиндан танишмоқчи эди холос. Лекин нима учун муносабатлари тез якун топди. Муаммо нимада ва кимда деган саволга албатта маданиятлараро мулоқот компетенциясининг йўқлигида деб жавоб берамиз. Машхур нидерландиялик психолог Герт Хофстеде маданий ўлчовларга кўра мамлакатларни коллективизм ва индивидуализм категорияларига бўлади [2. б.20]. Коллективизм жамиятига хос бўлган белгилардан бири “биз” тушунчаси бўлиб, унда жамоа манфаати шахсий манфаатдан устун туради. Хар бир харакат кўпчиликнинг маслахати билан амалга ошади, кўпчиликнинг фикри билан хисоблашиш лозим бўлади, ўзаро ёрдам, қўллаб-қувватлаш кутилади ва жуда ижобий бахоланади. Индивидуал категориядаги жамиятларда шахснинг мустақил қарор қабул қилиши ва мустақиллиги, шахсий манфаат устун туради. Бундай жамиятларда инсоннинг обрўъ-эътибори асосан ўз кучи билан хаётда эришган муваффақиятига қараб белгиланади. Бундай жамиятларда рақобат катта бўлганлиги сабабли, якка шахс сифатида ютуққа эришиш мураккаб кечади. Бундай босим остидаги мамлакатларда оила, турмуш қуриш каби анъанавий одатлар иккинчи ўринга тушади. Машхур нидерландиялик психолог Герт Хофстеде 1968-1972 йиллар оралиғида 132 мамлакатдаги IBM-концернининг ходимлари ўртасида ўтказган тадқиқотлари натижасида саноатлашган ғарб мамлакатлари, АҚШ, Австралия, Буюк Британия ва Канадани индивидуализм асосидаги мамлакатлари қаторига, Африка, Лотин Америкаси, жанубий Осиё мамлакатларини коллективизм маданиятлари сирасига киритади [3. б.21]. Юқоридаги холатга келадиган бўлсак, Германияда шахсий характердаги саволларни бериш, ойлик, маош, ўлим, дин каби мавзулар - табу, яъни ман этилган мавзулар хисобланади. Хулоса ўрнида Элс Оксаарнинг қуйидаги фикрини иқтибос сифатида келтирамиз “Ўзга халқ маданиятини билмасдан қилинган кичик бир хато, қўпол грамматик хатодан кўра ёмондир". Яъни ўзга халқлар тилини алохида холда эмас, балки ушша халқ маданиятининг ажралмас қисми сифатида комплекс ўрганиш лозимдир. Рус олими Тер-Минасова “тил бу маданиятнинг кўзгуси” деб изохлайди. Унда "нафақат инсонни ўраб турган реал дунё, инсоннинг яшаш шароитлари, балки миллий характер, менталитет, яшаш-тарзи, анъаналар, урф-одатлар, қадриятлар тизими, дунёни англаш ўз аксини топади" деб тушунтиради. У тилни хазинага қиёс қилади. “Тил маданий қадриятларни лексика, грамматика, идиоматика, мақоллар, бадиий ва илмий адабиётларда, ёзма ва оғзаки нутқда сақлаб келади (таржима бизники - Д. Ю.)” деб изохлайди [4. б.14].

Қуйида маданиятлараро мулоқот, ижтимоий-маданий компетенцияларнинг хорижий тилларни ўқитиш методикасига кириб келиши хақида мулохаза юритамиз. Методика сохасидаги хориж илмий манбаларида таъкидланадики, коммуникатив методика кириб келгунига қадар, мамлакатшунослик чет тили дарсларининг мухим бир қисми саналган. Тил ўрганиш билан бирга, ўқувчи мамлакат тўғрисидаги фактлар, яъни жуғрофияси, тарихи, сиёсий ва ижтимоий тизими хақида билимга эга бўлиш лозим бўлган. Маданият деганда ўша халқнинг урф-одатлари, байрамлари хақидаги билимларни бериш мухим рол ўйнаган. Бундан мақсад масалан, Германияга борганда умумий маълумотларга эга бўлиш учун ўрганишдан иборат бўлган [5. б.97]. Бугунги кунда эса биз коммуникацияга, яъни мулоқотга йўналтирилган чет тили дарслари хақида гапирамиз. Замонавий даврда хорижий тилни ўқитишдан асосий мақсад 
ўқувчини тили ўрганилаётган мамлакат вакиллари билан мулоқот қила олишга ўргатишдир. Яъни бу ерда фақат билим бериш эмас, балки у билан бирга компетенцияларни шакллантириш асосий вазифа хисобланади. Бунинг тасдиғи сифатида 2001 йилда Европа Иттифоқи Европа кенгаши томонидан "Умумевропа тил билиш компетенциялари: ўқиш, ўқитиш, бахолаш” (CEFR) концепциясининг нафақат Европа, балки бутун дунё мамлакатлари томонидан эътироф этилиши ва амалда жорий этилишини келтириш мумкин [6. б.13]. Мазкур концепцияда ўрганилиши ва ўзлаштирилиши лозим бўлган билим лаёқат, компетенциялар деб белгиланган. Ўқиш, ёзиш, эшитиш ва гапириш каби кўникмалар қаторига ижтимоий-маданий хамда маданиятларо мулоқот компетенциялари киритилди. "Ижтимоий-маданий билимлар деганда тили ўрганилаётган мамлакатдаги кундалик хаёт (мас. овқатланиш ва унинг қоидалари, байрамлар, бўш вақтни ташкил этиш в.х.к.з), яшаш-тарзи, инсонлар орасидаги муносабат, қадриятлар, анъаналар хақидаги билимлар назарда тутилади. [...] Маданиятлараро мулоқот компетенциялари тушунчаси остида ўз ва ўзга маданият ўртасидаги муносабатни англаш, ўзга маданият вакиллари билан мулоқотда маълум бир стратегияларни қўллай олиш, ўз ва ўзга маданият орасида маданий воситачи бўлиш, маданиятлараро мулоқотда юзага келадиган тушунмовчилик ва зиддиятли холатларда ечим топа олиш лаёқати тушунилади" [7. б.104, 106].

Мазкур компетенциялар Давлат таълим стандартлари Таълимнинг барча босқичлари битирувчиларининг чет тиллари бўйича тайёргарлик даражасига қўйиладиган талабларда хам белгилаб қўйилган. У ерда ихтимоий-маданий билимлар социолингвистик компетенция ва маданиятлараро мулоқот компетенциялари прагматик компетенциялар деб таърифланади. [8. б.10]. Бугун замон талабига мос, коммуникатив йўналтирилган чет тили дарслари 9 та коммуникатив-дидактик тамойилни инобатга олган холда ташкиллаштирилиши тавсия этилмоқда. Янги ўқув материалини ўрганиш воқеъликка йўналтирилган, реал хаёт билан боғлиқ бўлиши, компетенцияларни шакллантириш, ўқув мазмуни ўқувчининг талаб, эхтиёжи ва қизиқишларига мос келиши, интерфаол усулда ташкил этилиши, мустақил таълим олиш кўникмасини шакллантириши, кўп тиллилик тамойилидан фойдаланиш, ўрганганларини хаётда қўллашга йўналтирилган бўлиши лозим. [9. б.26-30]. Бу тамойиллар ичида албатта ўқувчиларда маданиятлараро мулоқот компетенцияларини шакллантириш марказий талаблардан хисобланади. Бу тамойилга кўра, тил доим лингвомаданий контекстда ўрганилади. Шунинг учун хам машғулотларда тили ўрганилаётган мамлакатнинг маданий меъёрлари ифодаланган холатларни яратиш ва бу орқали икки халқ маданияти ўртасидаги ўхшаш ва тафовутли жихатларни ўрганиш, тахлил қилиш, зиддиятли холатларда маълум стратегияларни қўллаш кўникмалари шакллантирилиши лозим.

Хулоса қилиб айтганда, хорижий тилларни ўрганиш ва ўқитишда тил ва маданиятга яхлит холат сифатида комплекс ёндашув зарур. Бу эса дунё халқларининг хамжихатлигига, бир-бирини тушунишига, бағрикенглик хислатларини шакллантириш ва ўзлигини яхшироқ англашга хизмат қилади.

\section{Адабиётлар рўйхати:}

1. Жалолов Ж.: Интерференция в методике обучения неродному языку. www.journal.fledu.uz"Ўзбекистонда хорижий тиллар" илмий-методик электрон журнал. №5-6/2017. c.90

2. Lüsebrink Hans-Jürgen: Interkulturelle Kommunikation. Interaktion Fremdwahrnehmung Kulturtransfer. Verlag J.B.Metzler - Stuttgart Weimar.2008.

3. Lüsebrink Hans-Jürgen: Interkulturelle Kommunikation. Interaktion Fremdwahrnehmung Kulturtransfer. Verlag J.B.Metzler - Stuttgart Weimar.2008.

4. Тер-Минасова С. Г.:Язык и межкультурная коммуникация: (Учеб. пособие) - М.: Слово/ Slovo , 2000.- 
5. Brinitzer, Michaela/ Hantschel, Hans-Jürgen/ Kroemer, Sandra/ Möller-Frorath, Monika/ Ros, Lourdes: DaF unterrichten. Basiswissen Didaktik Deutsch als Fremd- und Zweitsprache. Klett Verlag - Stuttgart. 2016

6. Ende, Karin/Grothjahn, Rüdiger/Kleppin, Karin/ Mohr, Imke: DLL 6, Curriculare Vorgaben und Unterrichtsplanung. Klett-Langenscheidt -München. 2017

7. Europarat. Rat für kulturelle Zusammenarbeit: Gemeinsamer europäischer Referenzrahmen für Sprachen: lernen, lehren, beurteilen. Hrsg. Vom Goethe-Institut Inter Nationes, KMK, EDK, BMBWK. Langenscheidt - Straßburg. 2001

8. Ўзбекистон Республикаси узлуксиз таълими тизимининг давлат таълим стандарти. Таълимнинг барча босқичлари битирувчиларининг чет тиллари бўйича тайёргарлик даражасига қўйиладиган талаблар. Вазирлар Махкамасининг 2013 йил 8 майдаги 124сон қарорига 1-илова. Ўзбекистон Республикаси қонун хужжатлари тўплами. 2013 й.

9. Ende, Karin/Grothjahn, Rüdiger/Kleppin, Karin/ Mohr, Imke: DLL 6, Curriculare Vorgaben und Unterrichtsplanung. Klett-Langenscheidt -München. 2017

\section{MAQOLLAR ORQALI FRANSUZ TILINI O'RGATISH MUAMMOLARIGA DOIR}

\section{Pulatova Nigina Aminovna SamDCHTI o'qituvchisi \\ E-mail : pulatova@samdchti.uz}

Annotation: Ushbu maqolada fransuz tilini Key words : fikrni bayon qilish; o'rgatishda maqollarning tutgan o'rni va ularning nutqni fransuzcha maqol va matallar; rivojlantirishdagi afzallaiklari hamda turli xil amaliy dars o'quvchilarning tayyorgarlik darajasi; namunalari bo'yicha tavsiyalar berib o'tilgan. tarjima.

Og'zaki nutq biror kimsa yo narsaga qaratilgan bo'lib,u nutq jarayonidagi muhit va emotsional xususiyatlarini o'zida aks ettiradi. Monolog, dialog, polilogkabi barcha turlari fikrni ma'lum formada bayon qilishni taqazo etadi. Binobarin, biror narsa yo kimsaga u yoki bu tarzda munosabat bildirishda maqol va matallarning qo'l kelishi, shubhasizdir. Maqollar vositasida eshitish malakalari rivojlanadi.

Ananaviy metod bilan u yoki bu shaklning yasalish qoidalari tushuntirilgandan so'ng, maqollardan misol keltirish mumkin. Chunonchi, morfologik materialni o'zlashtirish jarayonida turli affikslar vositasida so'z yasalishi bunga misol bo'la oladi:

- shaxs oti yasovchi - eur affiksi: Chat miauleur - petit faiseur.

- mavhum ot yasovchi suffikslar: Contentement passe richesse;

- sifat yasovchi suffikslar: Tendresse maternelle toujours se renouvelle va boshqalar.

Olmoshlar xususiyatini o'rganishda ham maqollar qo'l kelishi mumkin:

Qui (so'roq olmoshi) cherche - trouve.

Chacun (noaniq olmosh) peut être riche en promesse.

Celui-lá (ko'rsatish olmoshi) n'abat pas qui ne lutte.

On - noaniq kishilik olmoshi ham qator maqollar tarkibida keladi, u boshqa tillarga turlicha tarjima qilinishi mumkin. Masalan, Pas á pas on va loin. Qimirlagan qir oshar.

Fe'l formalarining isboti uchun ham maqol va matallardan misol keltirish mumkin. Chunonchi: Birinchi guruh fe'llarining noaniq formasi uchun: Donner tard c'est refuser.

- Uchinchi guruh fe'llarining noaniq formasi uchun: Vouloir c'est pouvoir.

Fe'l mayllari uchun:

- Buyruq mayli: Ne dites jamais - jamais, ne dites jamais - toujours. 
- Shart mayli: Si jeunesse savait, si vieillesse pouvait.

\section{Fe'l zamonlari uchun:}

- Hozirgi zamon: Le chat part, les souris dansent.

- O'tgan zamon: On récolte ce qu'on a semé.

- Kelasi zamon: Qui vivra verra.

- O’tgan zamon sifatdoshi: Chose défendue, chose désirée.

- Ravishdosh: En jouant on perd l'argent et le temps.

Ayrim fe'llarning turli vazifalarda namoyon bo'lishiga alohida e'tibor berish lozim. Masalan, - ée qo'shimchasi bilan bitgan o'tgan zamon sifatdoshiana shunday xususiyatga egadir: Parole jetée (o'tgan zamon sifatdoshi), prend sa volée (ot), Peché (ot), avoué (o'tgan zamon sifatdoshi), est á demi pardonné (majhul nisbat - être pardonné ).

Fransuzcha maqol va matallar tuzilishi nuqtai nazaridan barcha gap turlariga taaluqlidir. Sodda, yoyiq va yig'iq gaplarning bo'lishli va bo'lishsiz formalari, bog'lovchisiz qo'shma gaplar, ergashgan qo'shma gaplarning barcha turlari shular jumlasidandir.

O'qitishning hozirgi evristik (savol-javob) metodiga ko'ra, o'quvchilarning tayyorgarlik darajasiga qarab, ularga ma'lum sintaktik konstruksiyadagi (qurilishdagi) maqollarni tavsiya qilish mumkin. Bunda maqollardagi u yoki bu qoidaga mos holat tushuntirilmaydi, o'quvchilarning o'zlari uni deduktiv tarzda tushuntirib (asoslab) beradilar.Masalan, o'qituvchi o'zi oldindan tayyorlangan maqollarniona tiliga tarjima bilan tavsiya etadi, o'quvchilar esa, chog'ishtirma darajasining yasasalish qoidasini tushuntirib beradilar:

- Bien faire vaut mieux que bien dire.

- Un bon ami vaut mieux que cent parents.

- Mieux vaut manquer d'argent que d'ami.

Ikki tillilik va uch tillilik masalasi tillarni o'rganishdagina emas, balki shaxsni, uning dunyoqarashini shakllanishida ham katta ahamiyat kasb etadi. Til o'rganishda tarjima asosiy omillardan hisoblanadi.

Mazkur maqolada fransuz, o'zbek tillari doirasida maqol va matallar, ularning o'zaro munosib tarjima variantlari-muqobillari keltirilgan. Bundan maqsad, til o'rganish borasida, asos til bilan tarjima qilinayotgan tilning shakliy va mazmuniy tomonlarini mumkin qadar bir-biriga yaqinlashtirish ko'zda tutilgan.

Agar biz tarjimaning vazifasi - biror til vositasi yordamida yaxlit ma'lumotni boshqa tilga to'liq bera bilish lozimligini e'tiborga olsak, maqol va matallarning turli variantlarda namoyon bo'lishi ularni adekvat tarjima qilish lozimligidan dalolat beradi.

Maqollar tarjimalari til taraqqiyoti, ona tilidagi maqol va matallar sinonimik qatorini boyib borishi, umuman tarjima malakalarini rivojlantirishda keng imkoniyatlar yaratadi. Masalan, maqollarni ko'zdan kechirganda yo har ikkala tildagi obrazlarning aynan mos kelishi:

Il n'est poin de roses sans épines.

Tikonsiz gul bo'lmas.

Corbeau contre corbeau ne crèvent jamais les yeux.

Qarg'a qarg'aning ko'zini cho'qimaydi.

- Yoki ikki mazmunning aynan bir xil bo'lishiga qaramay faqat ikki tildagi obrazning mos kelishi.

Le loup mourra dans sa peau.

So'zma -so'z tarjima. Bo'ri o'z terisida o'ladi. 
- Yoxud hikmatli so'zlar orqali ifodalangan aynan bir tushunchani berishda har uchala tildagi obrazlarning o'zaro mos kelmasligi kuzatiladi.

Chacun ira au moulin avec son propre sac.

So'zma-so'z tarjima. Har bir kishi tegirmonga o'z qopi bilan boradi.

Har kim o'z aravasini o'zi tortadi.

Stilistik vositalarni o'rganishda maqollar muhim rol o'ynaydi. Jahon xalqlari maqollarida alliteratsiya, assonans, metafora, metonimiya, takrorlash, qiyoslash, qofiya kabi vositalar keng qo'llaniladi.

O'quvchilarning tayyorgarlik darajasiga qarab, ishni maqollar tarkibidagi ba'zi tovushlar talaffuzidan boshlash mumkin. Maqollarda uchraydigan ba'zi so'zlarningtalaffuzi-qiroati ustidaishlash jarayonida ularning ma'nosini qanday tushuncha ifodalanishini o'quvchilargatushuntirish kerak. Bunda tarjimasiz usuldan (masalan, rasm ko'rsatish), antonimlar yordamidagi perifrastik usuldan (masalan, mlade n'est pas malade $=$ sain) yoki tarjima usullaridan foydalanish mumkin.

Maqollar mazmunini tushinib yetgach, jumla ichida keladigan zarur tovushlar talaffuzini mustahkamlash yuzasidan mashqlar olib borish mumkin. Chunonchi, burun tovushlari uchun:

\section{Qui a bon voisin, a bon matin.}

Yoki yopiq [e] tovushi uchun: Parole jetée, prend sa volée va boshqalar.

Tovushlar talaffuzi ustidan ishlash bilan birga, intonatsiyaga ham rioya qilish lozim.

O'quvchilarning tovush, harf birikmalari va harflarning yozuvdagi o'ziga xos xususiyatlarini ongli ravishda o'zlashtirib olishlarini nazarda tutib, maqollardan mazkur hodisalarga doir maqol topishni buyurish mumkin.

Tarjima bo'yicha ishlaganda: bir tildagi realiylarning (tilning o'ziga xos xususiyatlarini) so'zma-so'z tarjimasi, semantik obrazlarni hisoblab chiqish, to'g'ri va ko'chma ma'nolar, ularni boshqa tildagi obrazlar bilan qiyoslash, stilistik vositalarni qayd etish mumkin;

- Ma'lum mavzudagi maqolllarni o'quvchilar alohida kartochkaga tarjimasiz (ya'ni bir tilda) yozib chiqadilar va bir-birlarini o'zaro tekshiradilar;

- Kartochkalar orqasiga uning tarjimasi yoziladi. Bunday mashqlar ona tilidan chet tiliga yoki chet tilidan ona tiliga tarjima qilishyo'sinida bajarilishi mumkin.

- Maqollarni eshitib turib tarjima qilish.

Og'zaki tarjima va eshitish malakalarini mustahkamlash uchun juft-juft yoki guruh bo'yicha ishlash mumkin. Bir o'quvchi maqol aytadi, boshqasi esa o'sha maqolning muqobilini keltiradi;

Mavzu haqida oldindan kelishib olingach (masalan, "Do'stlik", "Mehnatsevarlik" va shu kabilar), uning nomi alohida varaqqa yozib olinadi, so'ngra bir kishi ma'lum raqamli maqollarni ma'no jihatdan tartibga tushirmagan holda o'qiydi. Masalan:

1. Pas á pas on va loin.

2. On connaît l'ami dans le besoin.

3. Le temps passé ne revient pas.

4. Labour l'été vaut fumier.

Tinglovchi eshitgan maqolining tartib raqamini yozadi. Masalan, "Mehnatsevarlik" mavzusiga doir maqolga 1, 2 deb yozib boradi. Mashqning bu turi uzoq davom etmasligi lozim, biroq u o'quvchilarning bilim darajasini tekshirish maqsadida turli mavzularda tez-tez o'tkazib turilishi mumkin.

Tayyorgarlik ko'rmay gapirish malakalarini rivojlantirishda maqollar tayyor tezis vazifasini o'taydi. 
Mashqning qaysi turini tanlash o'quvchilarning tayyorgarlik darajasiga bog'liq bo'lib, bunda ko'pincha, rasm, slayd, kichik-kichik matnlar, plyonka yozuvlari singari qo'shimcha materiallar bo'lishini taqozo etadi.

- Ma'lum maqol mazmunini ifodalagan rasmni tanlab ko'rsatish va boshqalar;

- Do'stlik, dushmanlik, yaxshilik va yomonlik kabi xislatlar ifodalangan rasmlarga maqollarda tanlab nom qo'yish;

- Ikkinchi qismdagi ("hayotiy maslahatlar") maqollarni ovoz chiqarib o'qib mavzular bo'yicha tasnif qiling;

Maqollar ishtirokidagi o'yin turlari. O'yinlar yoshga qarab emas, shaxsga qarab belgilanadigan hodisa hisoblanadi. Binobarin, til o'rgatishda o'yin turlaridan foydalanish ham ijobiy natija beradi.

Mashhur nemis dramaturgi Fridrix Shiller “inson tom ma'noda inson bo'lgandagina o'ynaydi, ufaqt o'ynagan paytdagina haqiqiy inson hisoblanadi”, - degan edi. [1]

Fransuz psixologi Jan Piaje “o'yin bolalikka qaytish emas, balki ijodiyotga qaytishdir", - deb ta'kidlaydi. [2]

So'z, maqol va matallar ishtirokidagi o'yinlar o'tilgan darsni takrorlash, mustahkamlash maqsadida, shuningdek, sinfdan tashqarida bo'laigan turli mashg'ulotlar jarayonida o'tkazilishi mumkin.

Sinfdan tashqari ishlardan ko'zlangan maqsad:

- O'quvchilarda, xususan talabalarda tashkilotchilik qobiliyatini o'stirish;

- O'quvchilar jamoasini mustahkamlash; birgalikda turli ko'rik, tanlov va kechalar tashkil etish va ularda qatnashish, o'quvchilarni mustaqillikka o'gatish;

- Fanni o'zlashtirish va o'quvchilarda ishonch tuyg'ularini shakllantirishga yordam berish.

O’yinga qoniqarli yoki qoniqarsiz baho qo'yib bo'lmaydi. Bolaning topqirligi uchun yaxshi yoki a'lo baho qo'yish mumkin, biroq qoniqarli yoki qoniqarsiz baho qo'ymaslik kerak. O’yinlar doimo erkin, qiziqarli va xushchaqchaqlik ruhida o'tmog'i lozim.

Sinfdan tashqari ishlar hamkorlikda ishlash imkonini beradi, o'qituvchi rahbarligida o'quvchilar tashabbuskorligi va mustaqilligi uchun keng imkoniyatlar yaratiladi.

Mashg'ulot davomida, talaffuz, o'qish va Grammatik hodisalar ustida ish olib borilgandan so'ng quyidagi o'yin musobaqalarini o'tkazish mumkin:

- O'quvchilar bir-birini qo'lini ushlagan, aylana yasab, tutilmasdan (pauzasiz) maqol aytadi. Kimda-kim kamroq to'xtab, tezroq maqol aytsa - g'olib sanaladi.

Italyan yozuvchisi Janni Rodari o'zining "Fantaziya grammatikasi” degan asarida [3] o'yin davomida maqollardan foydalanishni maslahat beradi. Rodari metodining asosiy xususiyatlaridan biri mashhur ertak, maqol va matallarni qayta nomlash (o'rnini almashtirish) asosida bolalarda fantaziyani tarbiyalash va rivojlantirishdir. Masalan, bo'lishsiz formaga aylantirish yoki so'zlarni uning antonimi bilan almashtirish kabi. Bunday o'yinlarning qanday natija berishini, albatta, oldin aytish qiyin, biroq ularning jonli, qiziqarli o'tishi shubhasizdir. Masalan:

Musobaqani alohida kishilar o'rtasida yoki komandalararo o'tkazish mumkun.

- Ikki komanda navbati bilanbir tilde maqol aytadi, raqib tomon uning muqobilini boshqa tilda takrorlaydi;

- Bir tomon (komanda) maqol boshlaydi: Les cinq doigts de la main “... raqib tomon uni davom ettiradi: ... ne ressemblent point; birinchi tomon: "Donner l'aumône” ... desa ikkinchi tomon “... n'appauvrit personne” deb 
tamomlaydi. Bu o'yinni aylana yasagan holda ham o'tkazish mumkin, unda bir o'quvchi javob bera olmasa, sherigi javob qaytarishi mumkin;

- Biror hikoya aytib berilgach, o'quvchilar unga maqol yoki mataldan sarlavha topadilar.

Sinonimlarga oid maqol va matallarni bilishlari yuzasidan tanlov tashkil etish mumkin.

Jahon xalqlari hayotidan shu narsa ma'lumki, ba'zi hikmatli so'zlar mazmunan birbiriga zid, qarama-qarshi bo'lishi mumkin. Bunday paytlarda komanda bir nuqtai nazarni yoqlab, o'z fikrini isbotlashi mumkin. Masalan:

\section{Face d'homme porte vertu.}

Yuz amri - oftobdan issiq.

Les apparences sont tromoeuses.

Suvratiga boqma, siyratiga boq.

Devoriy gazetaga so'z o'yinlari, yumoristik rasmlar, dangasalik, yalqovlikka id satiric lavhalar, maqollar yuzasidan tanlov uyushtirishi lozim. Bunda "L'Union fait la force", "Santé passé richesse" kabi maqollardan sarlavha o'rnida foydalanish mumkin. Bunday mashg'ulotlar turli xil musobaqa, tanlov, o'tkir zehnlilar musobaqasini o'tkazishda qo'l kelishi mumkin: Chunonchi:

Qui cherche trouve.

Intilganga tole yor.

Qui langue a, á Rome va.

So'rab - so'rab Makkani topibdi. - kabi plakatlar uchun komandalarga yuqori ball qo'yish mumkin.

Fransuz tilini o'rgatishda maqollarning tutgan o'rni va ularning nutqni rivojlantirishdagi afzallaiklari muhimdir. Shuningdek, turli xil amaliy dars namunalari bo'yicha darsni tashkil qilish xorijiy til ta'limida ijobiy samara beradi.

\section{Adabiyotlar ro'yxati :}

1. F. Shiller. Собр. Соч . в 7 томах. М. 1957 том 6, стр. 302.

2. J. Piaget. "La psychologie de l'enfant" Paris, P. U. F. 1966.

3. Janni Rodari. "gramatika fantaziyasi", Almata, "Mektep", 1962.

\section{MADANIYATLARARO MULOQOT MUAMMOLARI VA YECHIMLARI}

Buxoro viloyati G'ijduvon tumani 17-maktab o'qituvchisi

E-mail : mavliyoqulova0816@mail.ru

Hayitov To'ymurod Vohid o'g'li

SamDU 1-bosqich talabasi

E-mail : toymurodxayitov@gmail.com

Annotation: Learning foreign languages from an early age is one of the tasks that should focus on the development of language competencies on the one hand, and on the other hand, the formation of skills in general, intercultural.
Key words : intercultural communication, communication, language, national character, interaction, socio-cultural norms, globalization, standardization, integration, language competence, tolerance, learning strategies.

Turli xalqlar, tillar va madaniyatlar yaqinlashgan bugungi kunda xorijiy tillarni o'rganish bilan birga, boshqa madaniyatlarga ham qiziqish ortib bormoqda. Madaniyatlararo muloqot masalalari umume'tiborni tortmoqda. Madaniyatlararo muloqot muammolari bilan 
shug'ullanadigan aksariyat xorijlik tadqiqotchilarning ta'kidlashlaricha, chet elliklar bilan muomalada bo'lganda grammatik, leksik va uslubiy xatolar kechiriladi, chunki bu ulardagi til bilimining yetarli emasligi bilan izohlanadi. Biroq muloqot jarayonida ijtimoiy-madaniy me'yorlarning, odob-axloq qoidalarining buzulishi salbiy qabul qilinadi. Chunki bunday me'yorlarning buzulishi muayyan ma'daniyat vakilining kamsitilishi yoki haqoratlanishiga sabab bo'lishi mumkin. Kommunikativ xatolar madaniy shok holatini yuzaga chiqarib, shaxslararo va millatlararo muloqotning muvaffaqiyatsizlikka uchrashiga, hatto jiddiy to'qnashuv, geosiyosiy oqibatlarga olib kelishi mumkin. Shundan kelib chiqqan holda, globallashuv, standartlashuv, integratsiyalashuv va madaniyatlarning aralashuvi yuz berayotgan bugungi kunda madaniyatlararo muloqot muammolarini o'rganish ularni tadqiq etish dolzarb masalalaridan biridir.

Hozirgi kunda til bilishning o'zi kommunikatsiya ishtirokchilari bir-birini tushunishlari uchun yetarli bo'lmaydi. O'zaro munosabatlarning muvaffaqiyatli va samarali bo'lishi uchun nutq ishtirok etgan va ishtirok etmagan muloqotning milliy-madaniy xususiyatlari, ijtimoiymadaniy me'yorlar, odob-axloq qoidalari, kommunikatsiyadagi ustuvor xususiyatlar hamda xushmuomalalikning milliy tizimi haqida bilimga ega bo'lish kerak bo'ladi. Prezidentimiz Sh. M. Mirziyoyevning ta'kidlaganidek: "Yoshlarimizning mustaqil fikrlaydigan, yuksak intellektual va ma'naviy salohiyatga ega bo'lib dunyo miqiyosida o'z tengdoshlariga hech qaysi sohada bo'sh kelmaydigan insonlar bo'lib kamol topishi o'ta muhim vazifalardan biridir".

Madaniyatlararo muloqot qilishga qiziqadigan va ochiqko'ngilli bola keyinchalik madaniyatlararo muloqotga qodir insonga aylanadi, zero bugungi kun chet tili mashg'ulotlarining e'tirof etilgan maqsadi ham shudir.

O'quvchining xorijiy tillarni bilish kompetentsiyasi til sohiblarining ona tilini bilish kompetentsiyasi bilan o'lchanmay, aksincha madaniyatlararo muloqotning ko'p qirrali vazifalarini uddalay olish qobiliyati bilan ham belgilanmoqda. Yosh o'quvchilar madaniyatlararo muloqotga qodir insonga xos ochiqlik va bag'rikenglik ruhida shakllanish darajasida rag'batlantirilishi hamda kichik yoshlilar uchun mo'ljallangan chet tili darslarida mazkur xususiyatlarni rivojlantira oladigan mazmundagi mavzular tavsiya qilinishi lozim. Chet tili bilan kichik yoshda tanishish tillarga nisbatan qiziqish uyg'otishi, til o'rganishga bo'lgan havasni rivojlantirishi hamda "bolani o'z tilidan boshqa yana bir tilda gaplasha olishga ruhlantirishi lozim".

Xorijiy tillarni o'rganish kichik yoshdan boshlangan hollarda bir tomondan til bilish kompetentsiyalarini rivojlantirilishga e'tibor qaratilishi, ikkinchi tomondan esa umumiy, madaniyatlararo muloqot qilish hamda o'quv strategiyalari bo'yicha qobiliyatni shakllantirish lozim vazifalardan biridir.

\section{Foydalanilgan adabiyotlar :}

1. Sh. Usmanova, G. Rixsiyeva „Millatlararo muloqot ” Toshkent 2017B.5

2. Sh. M. Mirziyoyev „, Erkin va farovon, demokratik O'zbekiston davlatini barpo etamiz" ToshkentO'zbekiston 2017 B.14

3. Фалькова Е. Ф. „, Межкультурная коммуникация восновых понятиях и определениях. Методическое пособие. СПб.: Ф-т филологии и искуств СПбГУ, 2007 -77с

4. Judith Martin, Thomas Nakayama. Intercultural communication in contexts. $-5^{\text {th }}$ ed. - New York: McGraw-Hill, 2010. -528p 


\section{INTERCULTURAL COMMUNICATION AS ONE OF THE MAIN DIRECTIONS IN LEARNING A FOREIGN LANGUAGE}

\section{Narzullaeva Farzona Farhodovna Student of Samarkand State Institute of Foreign Languages E-mail: narzullaeva999@mail.ru}

Annotation: The article presents a common understanding of language and communication between representatives of different cultures in the modern world. The role and place of the language in the system of intercultural communication and ensuring intercultural harmony is analyzed. The close connection and interdependence of language and culture is only so obvious that every foreign word reflects a foreign world and a foreign culture. The main goal of the article is to show the relationship of language and culture in each speech community, since the use of language is vital.
Key words : language, national values, intercultural communication, cultural models of communication, intercultural communication system

In today's world, the interaction of different cultures acts as a means of preserving cultural differences and cultural diversity. None of the cultures our world does not exist by itself and in isolation. Throughout historical development, there has been a continuous exchange of cultural achievements between representatives of different nationalities. Intercultural interaction is bilateral in nature, that is, it is an interdependent bilateral process, within which a change in state, content and the functions of one culture, under the influence of other. The interconnection of language and culture is a one-way movement, since if language is intended to reflect reality, and culture is an integral component of this reality itself, then language is presented as a simple reflection of culture. Where in any changes in reality lead to obligatory corresponding changes in culture, which in turn, it is reflected directly in the language itself. In this regard, we can say that in the event of a change in reality, nationalcultural stereotypes, as well as language, undergo changes. W. Humboldt systematized the available representations of language as a picture of the world, which contributed to the development of numerous theories. Initially, the main provisions of this theory were formulated by the American anthropologist F. Boas, who came to the conclusion that culture cannot be understood without knowing it language. In his opinion, knowledge of languages is important a guide to a complete understanding of customs and beliefs people, and a purely research of a purely linguistic nature is an integral part of the study of the psychology of the peoples of the world. The interaction of language and culture, within whose language seems to be an integral part of culture,inherited from the ancestors and acts as the main tool for the assimilation of culture. So, in terms ofS.G. Ter-Minasova language is an instrument of knowledge, information transfer, acts as a carrier of culture, because it reflects the world, stores and conveys knowledge about it world, forms a native speaker.

Perhaps one of the main and basic properties of the language is its versatility, which allows for the implementation of intercultural and intercultural communication. Tongue acts as the primary means of communication between by people. In terms of his communicative function, he can be called the main means of communication. Together with this language is the main carrier and powerful culture translator. So, through language, they can expressed all the components of culture. In the process of the evolution of culture, it appears as a means of interpersonal communication and communication in space and time. The main means of communication is the language in which most researchers see the most distinctive feature of culture. There is no culture outside the language, and culture at each stage of its development is symbolically formed, finds its expression, in the first it's the turn in the language. 
Thus, it is worth noting that in the study of language, culture plays an integral role since:

- a mirror of culture, reflecting not only the real the world that surrounds a person, but also the mentality of the people, their national character, customs, traditions, system of norms and values, as well as the picture of the world as a whole;

- a pantry, a piggy bank of culture, since all knowledge, skills, material and spiritual values that have been accumulated by the people for centuries are stored in its language system folklore, books, in oral and written speech;

- a carrier of culture, because it is through language is provided by its transmission from one generation to to another. So, children, in the process of inculturation, together with mastering the language, master the generalized experience of previous generations;

- an instrument of culture that ensures the formation of a person who, through language, perceives the mentality, traditions, customs of the people, and specific cultural image of the world.

Due to the fact that language is a leading tool communication, through which there is contact between individuals based on knowledge and understanding of two languages and cultures. Summarizing this statement, we have the right to assert that without knowledge of the secondary, cultural environment no communication is even possible the more so the study of a foreign language. In this regard, in the implementation of intercultural communication, one should adhere to some language rules that will ensure its effectiveness.First of all, it should be noted that in the framework of intercultural communication, the use of slang concepts and idioms is unacceptable. Particular attention should be paid to the interlocutor, a representative of another culture, to clarify and explain words that are not quite clear to him. In addition, it should be remembered that in some languages the accent is incorrect and the intonation is incorrect can fundamentally change the essence and meaning of the pronounced offers.

Thus, language takes a leading place in the system intercultural communication ensures success and the effectiveness of intercultural communication. Held analysis allowed us to see a noticeable parallel in the communicative interaction between people and talk about that language imposes on a person its vision of the world, the culture of another ethnic group and plays a decisive role in ensuring intercultural harmony and also in the study of a new language.

A sudden and radical change in the social life of our country, its "Discovery" and the desire to appear in the world - primarily Western - community brought languages back to life together. The main answer to the question communication between representatives of different nations and cultures lies in the fact that languages should be studied in indissoluble unity with the world and cultural peoples speaking these languages. To teach people to communicate (verbally and in writing), to teach to produce, create, and not only understand foreign language is a difficult task, complicated by that communication is not just a verbal process. Its effectiveness, in addition to knowledge language depends on many factors: conditions and culture of communication, etiquette rules, knowledge of non-verbal forms of expression (facial expressions, gestures), the presence of deep background knowledge and much more.

One of the links that make up the concept of communication is language, as a means of communication. This is the key that opens the door to our understanding with representatives of different cultures. However, as world practice has shown, when learning a foreign language, the banal memorization of the word speech production is not enough. The bottom line is the need for a deeper and more thorough study of the representative of culture, as a native speaker, with his worldview and mentality. As a result, intercultural communication arises this is the communication of people from different cultures. The main aspect of intercultural communication is overcoming the language barrier by overcoming the cultural barrier. That 
is, the urgent task in teaching foreign languages as a means of communication between peoples is to learn the language in indissoluble unity with the world and culture of peoples speaking this language. In the modern world, due to the accelerated development of political, economic, social and cultural relations between countries, the fact that success mainly depends on the training of representatives in the field of intercultural communication has been revealed.

It should be noted that intercultural communication acts as one of the main directions in the study of foreign languages. In addition, studying the language and culture of other peoples, we understand the important and inalienable role of language and culture in our lives, while we admire the language and culture of our country, its greatness and diversity, are proud of our cultural past and believe in the great future of the nation.

References:

1. E. M. Vereshchagin, V. G. Kostomarov. Language and culture. M., 1990.

2. Dezidema D., Budaeva S.V. Language as a means of broadcasting culture in the process of intercultural communication // Humanization of Education. - 2014.

3. Sadokhin A.P. Introduction to the theory of intercultural communication. - M.: Higher School, 2005.

4. https://en.wikipedia.org/

5. https://study.com/

\title{
INTERCULTURAL COMMUNICATION AS A LEADING FACTOR IN FOREIGN LANGUAGE EDUCATION
}

\section{Sattorova Fazilat Ermamatovna \\ Samarkand State University, phd doctorate E-mail: fazilat sattorova@mail.ru}

\begin{abstract}
Annotation: The article presents a theoretical analysis of the concepts of intercultural competence, the problem of formation of bachelors' intercultural competence of non-linguistic specialties of universities is dealt from the perspective of the conceptual ideas of the competence approach. It is shown their differences within the framework of competencebased learning foreign languages, provides a definition of the concept of "intercultural competence" of Bachelor of non-linguistic specialties of universities" and proved that the mastery of intercultural competence forms the basis for professional development and skills (mobility, flexibility, adaptability to new situations), it involves the integration of the person into the global and national cultures.
\end{abstract}

Key words : Intercultural, intercultural competence, competence approach, nonlinguistic specialties, communicative approach, linguistic competence;

The modern world is characterized by a tendency to expand and deepen international contacts in various fields of economic, socio-political, social and cultural life. In today's globalizing world, it is important to have a positive fruitful interaction of cultures, when language becomes the means of intercultural communication. This determines the need to address the problems of intercultural communication. However, communication with them may be difficult due to differences in the perception of the world, the language barrier and cultural characteristics. This situation requires the development of tolerance, the ability to quickly adapt and have the flexibility of thinking, in order to successfully carry out effective interaction and build communication. $[1 ; 14]$ The development of intercultural competence as a component of the professional competence of a future specialist takes place in the higher education system.

Today, the requirements for educational outcomes are described in the language of competencies and competencies. Most authors, in the concept of competence, single out a set of personal qualities that express the willingness (ability) of an individual to succeed, taking 
into account its social significance. In this context, the intercultural competence of bachelors of pedagogical education, non-linguistic specialties of universities is considered as part of the (foreign-language) communicative competence of the linguistic person, which is expressed in the ability to communicate through the language, that is, transmit thoughts and exchange them in various situations in the process of interaction with other participants communication, using the system of linguistic and speech norms correctly and choosing communicative behavior adequate to the authentic communication situation. In order for the process of preparing students of non-linguistic specialties for intercultural competence to be effective, a clear organization of the educational process is necessary, based on organizational, motivational, goal-oriented and meaningful components that contribute to mastering the body of knowledge and skills of intercultural competence [1, 19]. The content component includes a variety of intercultural knowledge, as included grammatical structures, rules of communication and etiquette, phraseological units, linguistic realities, knowledge about the features and traditions of a national character, knowledge about the country and its history [2, 9]. At the initial stage of training, the vocabulary of many students of non-linguistic specialties is not large enough, since most of them have no motivation to acquire knowledge. As a result, they face such a problem as the inability to express one's thoughts and with the inability to recognize and perceive the information received. Students of non-linguistic specialties use the word without realizing its meaning. Students' speech largely suffers from the inability to observe the thematic structure, to build enterprise communication, from a lack of expressiveness and imagery. The motivation-target component is associated with motivation to learn culture and language.

It assumes that students have a number of goals, namely: the development of interest in the discipline, the development and awareness of the needs for the acquisition of general and special knowledge, skills. The basis of the organizational component is the activities of the teacher, providing training for students of non-linguistic specialties for intercultural communication, aimed at the formation of intercultural competence. [3; 45]

It should be noted that in the process of acquaintance with a foreign language, studying it, a person gets an effective opportunity to join the national culture and history of the language being studied. In this regard, special attention is paid to the levels of intercultural competence among students of non-linguistic specialties. The high professionalism and competitiveness of the future specialist is determined not only by the presence of socio cultural, systemic, linguistic, and cultural knowledge, but also by their skills and abilities to prove themselves as an equal and full-fledged participant in the dialogue of cultures in the professional sphere. The formation of intercultural competence of students of non-linguistic specialties is possible only to a limited extent, taking into account the specifics of a particular subject-specialized communication. Hence, the problem of the formation of the intercultural competence of bachelors and non-linguistic specialties of universities lies in various goals for teaching foreign languages between communicative and intercultural approaches in linguodidactics.

\section{References:}

1. Чекун О.А. Педагогические условия подготовки студентов к межкультурной коммуникации (на примере неязыковых факультетов вуза). URL: http://www.dsHb (дата обращения 11.10.2016)

2. Гудков Д.Б. Межкультурная коммуникация: проблемы обучения. М.: МГУ, 2000

3. Елизарова Г.В. Межкультурная коммуникация: сущность, структура и функции. М.: Академия, 2014.

4. Астафурова Т.Н. Стратегии коммуникативного поведения в профессионально-значимых ситуациях межкультурного общения: Автореферат дис. ... д-ра пед. наук. М., 1997. 